UNITED STATES DEPARTMENT OF THE INTERIOR

GEOLOGICAL SURVEY

\title{
IN-SITU MEASUREMENTS OF SEISMIC VELOCITY AT 27 LOCATIONS IN THE LOS ANGELES, CALIFORNIA REGION
}

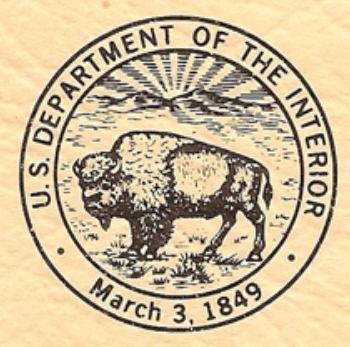

OPEN-FILE REPORT $80-378$

Any use of trade names and trademarks in this publication is for descriptive purposes only and does not constitute endorsement by the U.S. Geological Survey.

This report is preliminary and has not been edited or reviewed for conformity with Geological Survey standards and nomenclature

Menlo Park, California

1980 



\section{UNITED STATES DEPARTMENT OF THE INTERIOR}

GEOLOGICAL SURVEY

IN-SITU MEASUREMENTS OF SEISMIC VELOCITY AT 27 LOCATIONS IN THE LOS ANGELES, CALIFORNIA REGION

by

James F. Gibbs, Thomas E. Fumal, and Edward F. Roth

Open-File Report
80-378

This report is preliminary and has not been edited or reviewed for conformity with Geological Survey standards and nomenclature

Any use of trade names and trademarks in this publication is for descriptive purposes only and does not constitute endorsement by the

U. S. Geological Survey 


\section{CONTENTS}

Page

INTRODUCTION. . . . . . . . . . . . . . . . . . . . . . . 1

SELECTION AND LOCATION OF SITES . . . . . . . . . . . . . . . . 2

DRILLING AND SAMPLING PROCEDURES. . . . . . . . . . . . . . . 2

RECORDING PROCEDURES. . . . . . . . . . . . . . . . . . . . . . 3

REDUCTION OF GEOLOGIC DATA. . . . . . . . . . . . . . . . . . . . . . . 4

Description of Samples . . . . . . . . . . . . . . . . . . 4

Geologic $\log$. . . . . . . . . . . . . . . . . . . 5

Density Measurements . . . . . . . . . . . . . . . 6

REDUCTION OF SEISMIC DATA . . . . . . . . . . . . . . . . . . 6

Identification of Shear Wave Onset... . . . . . . . . 6

Travel Times and Average Velocities. . . . . . . . . . . . 7

Interval Velocities and Elastic Moduli . . . . . . . . . . 8

SUMMARY OF RESULTS. . . . . . . . . . . . . . . . . . . . . . 11

ACKNOWLEDGMENTS ............................ . . . 11

REFERENCES. . . . . . . . . . . . . . . . . . . . . . 12

FIGURES .............................. . . . . 13

TABLES. . . . . . . . . . . . . . . . . . . . . . . . 114 


\section{INTRODUCTION}

Studies conducted in the San Francisco Bay Region (Gibbs, Fumal and Borcherdt, 1980) have shown that average shear-wave velocity can be readily tied to quantitative estimates of ground motion such as ground amplification and earthquake intensity. Furthermore, when certain physical properties of the geologic materials such as texture, hardness and fracture spacing are observed during geologic mapping, a method can be used to predict shear-wave velocity from the descriptions of geologic units. By measuring shear-wave velocities in key units together with the above data, regional maps depicting the earthquake shaking hazard can be compiled.

The goals of the current program are to provide shear-wave data in the Los Angeles area to compare with that in the San Francisco Bay Region where high-strain intensity data are available. Data from twenty-seven locations are summarized in this report as part of a continuing project to seismically zone the Los Angeles area. 
SELECTION AND LOCATION OF SITES

The selection of the first 27 sites (fig. 1) in this study was guided by the availability of other data in the Los Angeles area that are applicable to the overall problem of estimating earthquake ground motions. These data are (1) strong motion records from the 1971 San Fernando earthquake, (2) ground motion recorded from nuclear explosions and (3) geologic mapping (in progress). Sites are selected on the basis of each data set with priority given to the order listed.

\section{DRILLING AND SAMPLING PROCEDURES}

At each site selected, a hole $12.4 \mathrm{~cm}$ in diameter is drilled to a depth of $30 \mathrm{~m}$ using a truck-mounted drill and a rock bit with mud and water circulation. The boring is then cased with $7.6 \mathrm{~cm}$ diameter PVC plastic pipe and backfilled with drill cuttings and "pea" gravel. Casing insured accessibility of the hole and provided a secure clamping surface for the seismic probe.

Samples are taken in each of the holes at depths of approximately $3 \mathrm{~m}$, $7.5 \mathrm{~m}, 30 \mathrm{~m}$, and at boundaries defined by continuously monitoring the drill cuttings and the drill reaction. The type and number of samples taken at each site is determined by the type of material, the number of significant lithologic boundaries, and variations in weathering. 
In soils, standard penetration measurements are made and samples are taken using a "Pitcher" core barrel and a "Shelby" thin tube liner. Core barrel samples are also taken in soils with large amounts of hard rock fragments and in firm rock. Samples are obtained in hard rock using a core barrel with a diamond core bit.

\section{RECORDING PROCEDURES}

Compressional waves are generated at each site by the vertical impact of a sledge hammer on a steel plate. A signal produced by the opening of a switch attached to the hammer is recorded for determining origin time.

Shear waves are generated using the horizontal traction source introduced by Kobayashi (1959) and discussed by Warrick (1974). Briefly, the method consists of applying a horizontal impact to a large timber $(244 \times 30 \times 18$ $\mathrm{cm})$. The timber is placed on a flattened soil surface and held firmly in place by the front wheels of a truck. A steel pipe extends through the timber and supports a $30 \mathrm{~kg}$ hammer to which is attached an impact switch. The specially constructed hammer rolls on bearings and moves a distance of $45 \mathrm{~cm}$ along the pipe before impacting the timber. The "horizontal traction" source generates a high proportion of $S$ - to $P$-wave energy. The timber is struck twice, once in each direction. The two impacts reverse the polarity of the S-waves but not the polarity of the smaller amounts of P-wave energy. Comparison of the two signals provides an important tool for identifying the onset of the S-wave.

The timber is offset $2.0 \mathrm{~m}$ from the hole and a three-component geophone package (natural frequency $14 \mathrm{~Hz}$ ) is placed within $9 \mathrm{~cm}$ of its center. The signals recorded from the surface geophones are used to monitor the input signals and determine the origin time for the generated S-waves. The arrangement of timber, steel plate, and surface geophone package is illustrated in figure 2. 
The P-waves generated by a vertical impact on the steel plate and the S-waves generated by striking the timber in both directions are recorded separately. This procedure is repeated for each $2.5 \mathrm{~m}$ interval (closer spacing is sometimes used to obtain a velocity in thin layers) in the drill hole.

Two downhole geophones were used in this study. One has an inflatable diaphragm and a delinometer which under most circumstances permits orientation of the horizontal geophones from the surface. Proper orientation (parallel and perpendicular to the source) aides in identifying the onset of the S-wave. A second downhole geophone was used as a backup instrument in several holes in this study. This geophone has a spring clamping mechanism and cannot be oriented from the surface. Both instruments detect three components of motion.

The signals from the downhole and surface seismometers and the impact switches are recorded on photographic paper. The velocity unit-impulse response of the recording system is essentially flat from $2 \mathrm{~Hz}$ to above 100 Hz. A detailed description of the recording instrumentation is presented by Warrick and others (1961). The recording oscillograph is modified for this project by adding $500 \mathrm{~Hz}$ galvanometers and increasing the paper speed to $46 \mathrm{~cm} / \mathrm{sec}$.

\section{REDUCTION OF GEOLOGIC DATA}

\section{Description of Samples}

Portions of each of the samples are examined and described in the laboratory. The terms used for the descriptions are summarized on figure 3. The sample descriptions are presented in the left-hand columns of figures $26-52$. 
The soil samples are described using the field techniques of the Soil Conservation Service and those specified for the Unified Soil Classification System. Descriptions include soil texture, color, amount and size of coarse grains, plasticity, dry and wet consistency, and moisture condition. Texture refers to the relative proportions of clay, silt, and sand particles less than $2 \mathrm{~mm}$ in diameter. The dominant color of the soil and prominent mottles are determined from the Munsell soil color charts.

Descriptions of rock samples include rock name, weathering condition, color, grain size, hardness, and fracture spacing. Classifications of rock hardness and fracture spacing are those used by Ellen and others (1972) in describing hillside materials in San Mateo County, CA. The weathering classification is modified from that used by Aetron-Blume-Atkinson (1965) in describing Tertiary sedimentary rocks in the foothills of the Santa Cruz Mountains, CA. Geologic Log

Geologic logs are complied for each hole using the field $\log$ and descriptions of the samples (figures 26-52). The field $\log$ is based on the reaction of the drill rig, a continuous record of drill cuttings, preliminary on-site inspection of samples, and inspection of nearby roadcuts and gullies.

Most information needed for describing relatively well-sorted soils and such properties of rock as lithology, color, and hardness are readily obtained from cuttings. Inspection of samples and nearby outcrops is also necessary to determine the nature of poorly sorted materials and to determine fracture spacing. Reaction of the drill rig is also useful in determining degree of fracturing as the rate of penetration in rock is highest for very closely fractured and crushed materials and drilling roughness generally is at a maximum in closely to moderately fractured rock. In-situ consistency of soil is determined largely from standard penetration measurements and rate of drill penetration. 


\section{Density Measurements}

Values for density are required to calculate elastic moduli from measurements of seismic velocity. Densities were measured for the diamond core samples and most of the penetration samples by weighing a small piece of sample and obtaining its volume by the mercury displacement method. A different procedure was used for very friable materials such as grus or poorly-sorted materials which necessitated using a large sample. A section was cut from the Shelby tube containing the sample, its height and diameter measured and the sample extruded for weighing.

While the accuracy of the density measurements is generally sufficient for calculation of elastic moduli, a number of the samples used to obtain densities were not entirely representative of the material in-situ. Penetration samples were somewhat disturbed and many had dried out before measurements could be made. Densities of hard rock obtained using intact fragments may be higher than in-situ densities by approximately $0.1-0.2$ $\mathrm{gm} / \mathrm{cc}$, depending on the amount and openness of fractures.

\section{REDUCTION OF SEISMIC DATA}

\section{Identification of Shear Wave Onset}

To aid in the identification of the shear wave arrivals, the signals recorded in the drill hole from impacting the timber in opposite directions are superimposed and drafted on a common time base (figs. 53-79). The S-wave group is easily identified when displayed in this manner, by a $180^{\circ}$ phase inversion. The onset of the S-wave is chosen as the start of the first clearly inverted phase in the group. The interpretation proceeds from the bottom record, to the top using phase correlation at each recording depth. The onset of the S-wave arrival (arrows) and the first peak of the S-wave arrival (dots) are identified for each depth and are indicated on figures 53-79 for each site. 
It was not possible at every site to control the orientation of the downhold seismometer package because of high viscosity drilling mud left in the hole; hence, the relative amounts of S-wave energy recorded on the two horizontal seismometers vary with depth. The S-wave arrival is generally most easily identified on the horizontal seismogram with the largest amplitudes (e.g., see fig. 59). Comparison of the signals recorded on the horizontal sensors with that recorded on the vertical sensor shows that the S-wave energy generated by the horizontal traction source is at least twice as large as the P-wave energy.

On many of the horizontal seismograms some P-wave energy prior to the onset of the S-wave is apparent. Some $\mathrm{P}$-wave energy is generated by the horizontal traction source and some probably results from conversion of $S$ to $P$ at seismic boundaries. In some cases the polarity of this P-wave energy is reversed and careful consideration of the entire record section is required to identify the S-arrival. In general, the onset of the S-wave is easier to identify at sites underlain by the various types of soil than for sites underlain by the more consolidated rock units. Travel Times and Average Velocities

To determine the travel time for the S-wave onset identified from the record sections (figs. 53-79), the following times are measured with respect to a $100 \mathrm{~Hz}$ time code signal recorded on the records:

1) $t_{1}$ time of break in signal from impact switch

2) $t_{2}$ onset time of S-wave arrival on inline uphole geophone

3) $t_{3}$ onset time of identified $S$-wave arrival on downhole sensors The time considered to be the origin time for the S-wave recorded on the downhole sensor is the onset time of the S-arrival on the uphole inline sensor. To reduce the uncertainties in determining this origin time, an average travel time from the source to the uphole geophone $\left(t_{A}\right)$ is determined from the set of values, $t_{2}-t_{1}$, measured at each depth. 
The travel time for the first S-arrival is given by

$$
t_{s} \equiv\left(t_{3}-t_{1}\right)-t_{A} \text {. }
$$

A corrected $S$-wave travel time $\left(t_{S}\right)$, corresponding to the travel time for a vertical ray path, is computed from $t_{s} \equiv t_{s}+t_{c}$ where $t_{c}$ corresponds to a timing correction (cosign of the angle of ray incidence) due to the distance the plank is offset from the center of the hole (usually $2.0 \mathrm{~m}$ ). Average velocities from the surface are determined by dividing the corrected travel time by the corresponding depth. The travel time for the first S-peak is determined similarly. The origin corrections $\left(t_{2}-t_{1}\right)$, the travel times of the first $S$-arrival and the first $S$-peak $\left(t_{s}\right)$, the corrected travel times for the first S-arrival and the first S-peak $\left(t_{S_{C}}\right)$, and the average corresponding velocities computed at each site are presented in tables 1-27.

The travel times for the $P$-waves generated by a vertical impact on a steel plate are determined in the same way as for the S-waves, except that the origin time for the P-wave is given by the impact switch and no origin correction is necessary. The travel times, the corrected travel times, and the average velocities for the P-waves are also presented in tables 1-27. Interval Velocities and Elastic Moduli

Calculation of interval velocities and elastic moduli requires determination of depth intervals over which the velocity is approximately constant within the uncertainty of the travel-time measurements. To determine these depth intervals, the travel time data (tables 1-27) are plotted as a function of depth (figs. 80-106) and the geologic logs (figs. 26-52) are simplified and displayed graphically on the travel time curves (figs. 80-106). Depth intervals for velocity determinations are selected on the basis of distinct changes in slope of the travel time plots and evidence for lithologic boundaries. For those geologic materials with S-velocities greater than $350 \mathrm{~m} / \mathrm{sec}$, the intervals are required to contain at least four travel time 
measurements to avoid determining a velocity from a travel time differential due in large part to measurement error.

Velocities are calculated for each of the selected intervals (tables 28-54) from the slope of the linear regression line which best fits the travel time data in a least squares sense (Borcherdt and Healy, 1968, eqs. 3.1-3.5). The equation of the linear-regression line which best fits, in a least-squares sense, a sample of $n$ pairs of time-depth coordinates $\left(x_{1}, t_{1}\right), \ldots\left(x_{n}, t_{n}\right)$ is

where

$$
\begin{aligned}
& t(x)=a+b(x-\bar{x}) \\
& \bar{x} \equiv \frac{1}{n} \sum_{i=1}^{n} x_{i}, a \equiv \frac{1}{n} \sum_{i=1}^{n} t_{i},
\end{aligned}
$$

the intercept is

$$
\text { INCPT } \equiv \frac{1}{n} \sum_{i=1}^{n} t_{i}-b \bar{x} \text {, and }
$$

the slope is

$$
b \equiv \sum_{i=1}^{n} w_{i} t_{i}
$$

with $\quad w_{i}=\left(x_{i}-\bar{x}\right) / D$ and $D \equiv \sum_{k=1}^{n}\left(x_{k}-\bar{x}\right)^{2}$

The desired velocity (VEL) is given by $V=1 / b$. Assuming the standard statistical model (Borcherdt and Healy, 1968), the 68.3 confidence level, uncertainty interval (UNC INT) for the velocity is estimated by

$$
\left(\frac{1}{b}+S_{b}, \frac{1}{b-S_{b}}\right)
$$

where

$$
\cdot S_{b} \equiv \sum_{(n-2) D}^{1} \sum_{i=1}^{n}\left(t_{i}-t\left(x_{i}\right)\right)^{2}
$$


is the standard error of the regression coefficient.

For these depth intervals with measurements of density $(\rho)$, the shear modulus (SHEAR MOD, M) and bulk modulus (BULK MOD, K) is calculated (tables 28-54) using

$$
M=\rho V_{s}^{2}
$$

and

$$
K=\rho V_{p}^{2}-\frac{4}{3} M
$$

Poisson's ratio $(\sigma)$ is calculated (tables 28-54) using

$$
\sigma=\frac{\left(\begin{array}{c}
V_{p} \\
\frac{V}{s}
\end{array}\right)^{2}-2}{2\left(\frac{V_{p}}{V_{s}}\right)^{2}-2}
$$




\section{SUMMARY}

Seismic velocities have been measured in the near surface geologic materials at 27 locations in the Los Angeles and Oxnard-Ventura, California, areas. S-wave and $\mathrm{P}$-wave measurements were made at $2 \frac{1}{2} \mathrm{~m}$ intervals in drill holes to a depth of $30 \mathrm{~m}$. Geologic logs were compiled by continuously monitoring drill cuttings and by analys is of cored samples. Density measurements were made from samples for the calculation of elastic moduli.

Previous studies in the San Francisco Bay region (Gibbs et al., 1980) have shown that average shear velocity can be correlated with ground motion amplification recorded from nuclear explosions and with observed intensities from the 1906 earthquake. A detailed study using shear velocity data from 59 locations (Fumal, 1978) has shown that certain physical properties of the near surface geologic materials can be used to predict velocity. Measurements of shear velocity at a number of strategic locations will permit extrapolation of results from the San Francisco Bay region to the Los Angeles region.

\section{ACKNOWLEDGMENTS}

The authors wish to thank John Tinsley and Albert Rogers for their help with site selection and John Tinsley again for his help with the Geology of the Los Angeles region. 
Aetron-Blume-Atkinson, 1965, Geologic site investigations for Stanford Linear Accelerator Center: Report No. ABA-88.

Borcherdt, R. D., and Healy, J. H., 1968, A method for estimating the uncertainty of seismic velocities measured by refraction techniques: Bul1. Seism. Soc. Am., 58, p. 1769-1790.

Ellen, S. D., Wentworth, C. M., Brabb, E. E., and Pampeyan, E. H., 1972, Description of geologic units, San Mateo County, California: Accompanying U.S. Geol. Survey Miscellaneous Field Studies Map, MF-328.

Fuma 1, T. E., 1978, Correlations between seismic wave velocities and physical properties of near-surface geologic materials in the southern San

Francisco Bay region: U.S. Geological Survey Open-File Report 78-1067.

Gibbs, J. F., Fumal, T. E., and Borcherdt, R. D., 1980, In-situ measurements of seismic velocities for seismic zonation in the San Francisco Bay Region: submitted to Bull. Seism. Soc. of Am., Nov. 1979.

Kobayaski, N., 1959, A method of determining the underground structure by means of SH waves: Zisin, ser. 2, v. 12, p. 19-24.

Soil Survey Staff, 1951, Soil Survey Manual: U.S. Department of Agriculture Handbook 18.

Sowers, G. B., and Sowers, G. F., 1970, Introductory Soil Mechanics and Foundations: MacMillan, New York.

Terzaghi, K., and Peck, R. B., 1967, Soil Mechanics in Engineering Practice: John Wiley and Sons, New York.

U.S. Army Corps of Engineers, 1960, The unified soil classification system: Tech. Memorandum No. 3-357, Waterway Experiment Station, Vicksburg, Mississippi.

Warrick, R. E., 1974, Seismic investigation of a San Francisco Bay mud site: Bull. Seism. Soc. Am., v. 64, p. 375-385.

Warrick, R. E., Hoover, D. B., Jackson, W. H., Pakiser, L. C., and Roller, J. C., 1961, The specifications and testing of a seismic-refraction system for crustal studies: Geophysics, v. 26, p. 820-824. 
Regional location map

Shear-wave apparatus

Description of geologic logs

SITE NO.
Fig. 1

Fig. 2

Fig. 3

NAME

1 MAGNOLIA

Detailed location map

Geologic log

Record section

Travel-time plot

Tables:

"Travel-times and average velocities"

"Interval velocities and elastic moduli"

2 Ist LUTHERAN

Detailed location map

Geologic log

Record section

Travel-time plot

Tables:

"Travel-times and average velocities"

"Interval velocities and elastic moduli"

3 TERMINAL ISLAND

Detailed location map

Geologic log

Record section

Travel-time plot

Tables:

"Travel-times and average velocities"

"Interval velocites and elastic moduli"

4 LAKEWOOD GOLF COURSE

Detailed location map

Geologic log

Record section

Travel-time plot

Tables:

"Travel-time and average velocities"

"Interval velocities and elastic moduli"
Fig. $4 \quad 22$

Fig. $26 \quad 44$

Fig. $53 \quad 73$

Fig. $80 \quad 87$

114

141

Fig. 4

Fig. 27

Fig. 54

Fig. 81

22

45

73

88

115

142

Fig. 5

23

Fig. 28

46

Fig. 55

Fig. 82

74

89

116

143

Fig. 6

24

Fig. 29

47

Fig. 56

74

Fig. 83

90 
5 F.S. 105

Detailed location map

Fig. 7

Fig. 30

Fig. 57

Record section

Fig. 84

25

Travel-time plot

Tables:

"Travel-time and average velocites"

"Interval velocities and elastic moduli"

6 COMPTON AIRPORT

Detailed location map

Geologic log

Record section

Travel-time plot

Tables:

"Travel-times and average velocities"

"Interval velocities and elastic moduli"

Fig. 8

Fig. 31

49

Fig. 58

75

Fig. 85

7 COMPTON CIVIC CENTER

Detailed location map

Fig. 8

26

Geologic log

Record section

Travel-time plot

Tables:

"Travel-times and average velocities"

"Interval velocities and elastic moduli"

Fig. 32

Fig. 59

50

Fig. 86

76

8 HOLIDAY INN

Detailed location map

Geologic log

Record section

Travel-time plot

Tables:

"Travel-times and average velocities"

"Interval velocities and elastic moduli"

Fig. 9

27

Fig. 33

Fig. 60

Fig. 87

51

76

94

121

148

9 VETS HOSPITAL

Detailed location map

Geologic log

Record section

Travel-time plot

Tables:

"Travel-times and average velocities"

"Interval velocities and elastic moduli"

Fig. 10

28

Fig. 34

52

Fig. 61

77

Fig. 88

122

149 
10 NEWPORT BEACH SDP2

$$
\text { Detailed location map }
$$

Fig. 11

Geologic log

Record section

Fig. 35

54

Travel-time plot

Fig. 63

78

Tables:

"Travel-times and average velocities"

Fig. 89

"Interval velocities and elastic moduli"

11 KATELLA SCHOOL

Detailed location map

Fig. 12

Fig. 36

Geologic log

Record section

Fig. 62

Travel-time plot

Fig. 90

Tables:

"Travel-times and average velocities"

"Interval velocities and elastic moduli"

12 ST. JUDES HOSPITAL

Detailed location map

Geologic log

Record section

Travel-time plot

Tables:

"Travel-times and average velocities"

"Interval velocities and elastic moduli"

Fig. 13

Fig. 37

Fig. 64

Fig. 91

77

97

124

13 ROWLAND HEIGHTS

Detailed location map

Geologic log

- Record section

Travel-time plot

Tables:

"Travel-times and average velocities"

"Interval velocities and elastic moduli"

Fig. 14

Fig. 38

Fig. 65

Fig. 92

31

57

79

98

125

152

14 EL MONTE COURT HOUSE

Detailed location map

Geologic log

Record section

Travel-time plot

Tables:

"Travel-times and average velocities"

"Interval velocities and elastic moduli"

Fig. 15

Fig. 39

33

Fig. 66

59

Fig. 93

80

100 
15 VERDUGO PARK

Detailed location map

FIg. 16

34

Geologic log

Fig. 40

60

Record section

Fig. 67

80

Travel-time plot

Fig. 94

101

Tables:

"Travel-times and average velocities"

128

"Interval velocities and elastic moduli"

155

16 20th CENTURY

Detailed location map

Fig. 17

Geologic log

Record section

Travel-time plot

Tables:

"Travel-times and average velocities"

"Interval velocities and elastic moduli"

Fig. 41

35

Fig. 68

61

Fig. 95

81

102

129

156

17 UPPER VAN NORMAN DAM

Detailed location map

Geologic log

Record section

Travel-time plot

Tables:

"Travel-times and average velocities"

"Interval velocities and elastic moduli"

Fig. 18

36

Fig. 42

Fig. 69

Fig. 96

18 PACOIMA MEMORIAL HOSPITAL Detailed location map

Geologic log

Record section

Travel-time plot

Tables:

"Travel-times and average velocities"

"Interval velocities and elastic moduli"

Fig. 19

37

Fig. 43

63

Fig. 70

Fig. 97

82

104

131

158

19 SYLMAR HIGH SCHOOL

Detailed location map

Fig. 20

38

Geologic log

Record section

Fig. 44

64

Travel-time plot

Fig. 71

82

Tables:

Fig. 98

105

"Travel-times and average velocities"

132

"Interval velocities and elastic moduli"

159 
20 MISSION HILLS P.0.

Detailed location map $\quad$ Fig. $20 \quad 38$

Geologic log

Fig. $45 \quad 65$

Record section

Fig. 72

Travel-time plot

Fig. 99

Tables:

"Travel-times and average velocities"

"Interval velocities and elastic moduli"

21 ETON SCHOOL

Detailed location map

Geologic log

Record section

Travel-time plot

Tables:

"Travel-times and average velocities"

"Interval velocities and elastic moduli"

Fig. $21 \quad 39$

Fig. $46 \quad 66$

Fig. $73 \quad 83$

Fig. $100 \quad 107$

22 CAMARILLO STATE HOSPITAL

Detailed location map

Geologic log

Record section

Travel-time plot

Tables:

"Travel-times and average velocities"

"Interval velocities and elastic moduli"

Fig. $22 \quad 40$

Fig. $47 \quad 67$

Fig. $74 \quad 84$

Fig. $101 \quad 108$

135

162

23 PACIFIC MISSILE

Detailed location map

Geologic log

Record section

Travel-time plot

Tables:

"Travel-times and average velocities"

"Interval velocities and elastic moduli"

Fig. $23 \quad 41$

Fig. $48 \quad 68$

Fig. $75 \quad 84$

Fig. $102 \quad 109$

24 VENTURA CO. AIRPORT

Detailed location map

Geologic log

Record section

Travel-time plot

Tables:

"Travel-times and average velocities"

"Interval velocities and elastic moduli"

Fig. $24 \quad 42$

Fig. $49 \quad 69$

Fig. $76 \quad 85$

Fig. $103 \quad 110$

136

163

137

164 
25 MANDALAY BEACH

Detailed location map

Fig. 24

42

Geologic log

Record section

Fig. 50

70

Travel-time plot

Fig. 77

85

Tables:

"Travel-times and average velocities"

Fig. 104

111

"Interval velocities and elastic moduli"

138

165

26 VENTURA CO. GENERAL

Detailed location map

Geologic log

Record section

Travel-time plot

Tables:

"Travel-times and average velocities"

"Interval velocities and elastic moduli"

Fig. 25

43

Fig. 51

71

Fig. 78

86

Fig. 105

112

139

166

27. BARD SANITARIUM

Detailed location map

Geologic log

Record section

Travel-time plot

Tables:

"Travel-times and average velocities"

Fig. 25

43

Fig. 52

72

Fig. $79 \quad 86$

Fig. $106 \quad 113$

"Interval velocities and elastic moduli"

140

167 


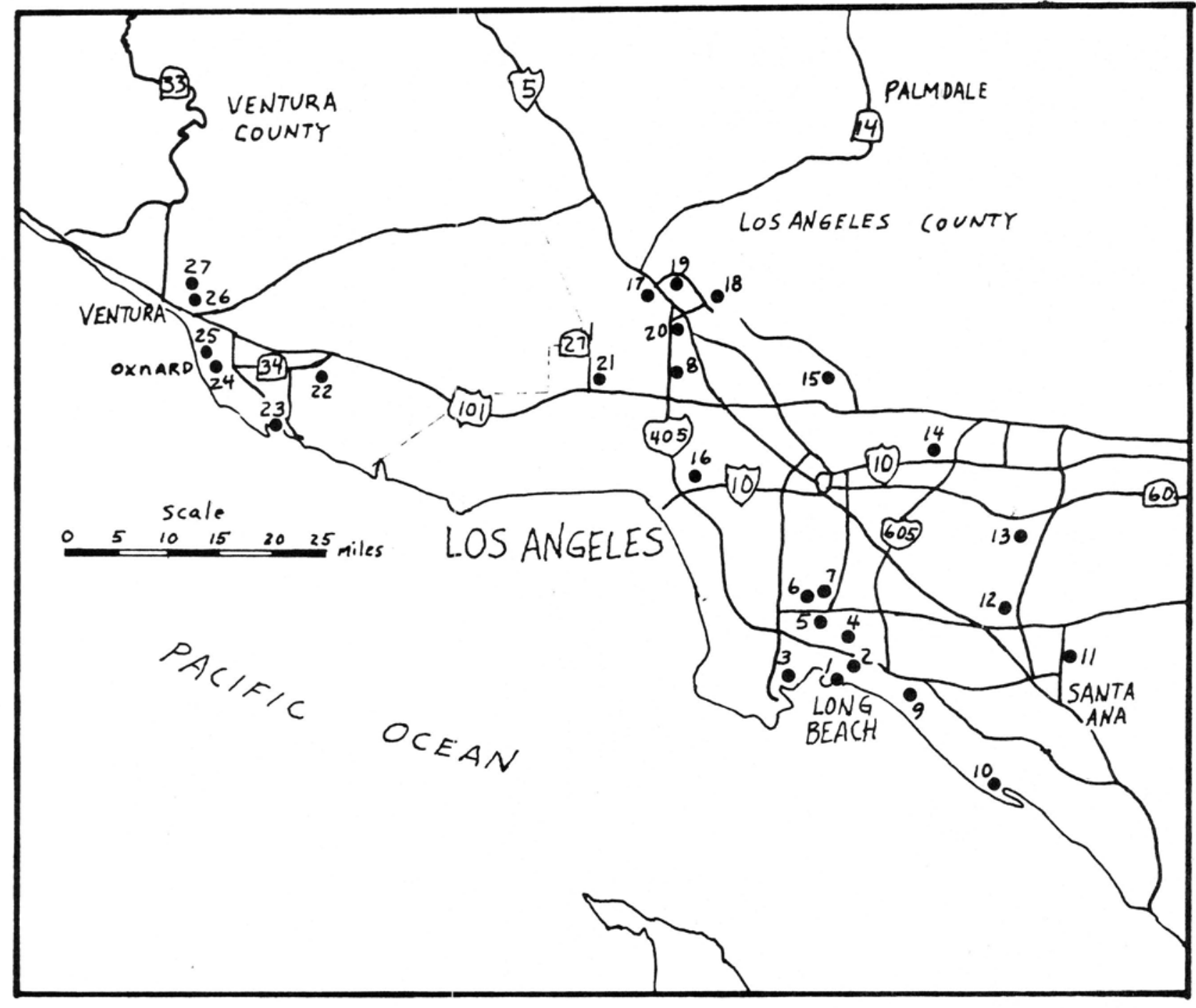

Figure 1. Generalized map of the Los Angeles region showing the approximate locations of shear-wave sites. Detailed locations are shown in figures 4-25. 
a)

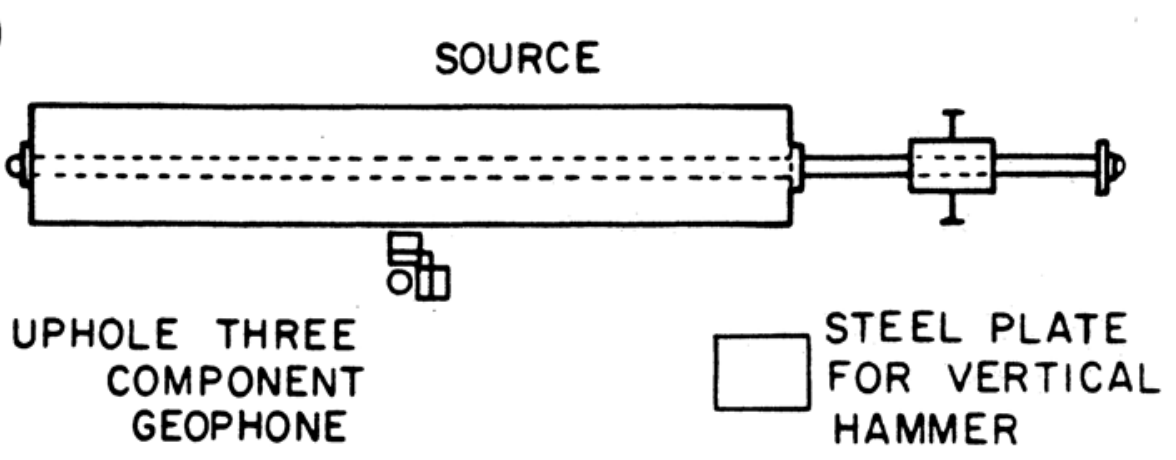

b)

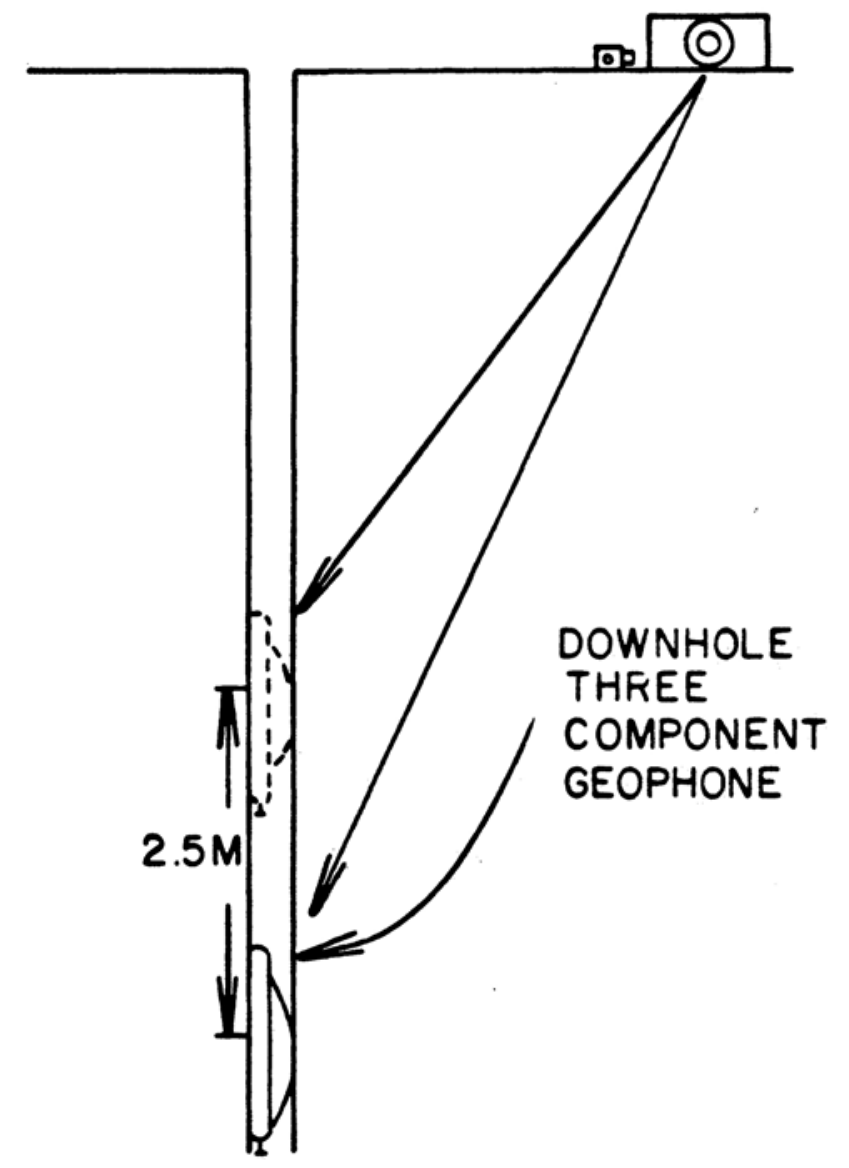

Figure 2. Details of field apparatus, (a) hammer and plank and (b) section showing three-component downhole geophone. 
Texture: the relative proportions of clay, silt, and sand below $2 \mathrm{~mm}$. Proportions of larger particles are indicated by modifiers of textural class names. Determination is made in the field mainly by feeling the moist soil (Soil Survey Staff, 1951).

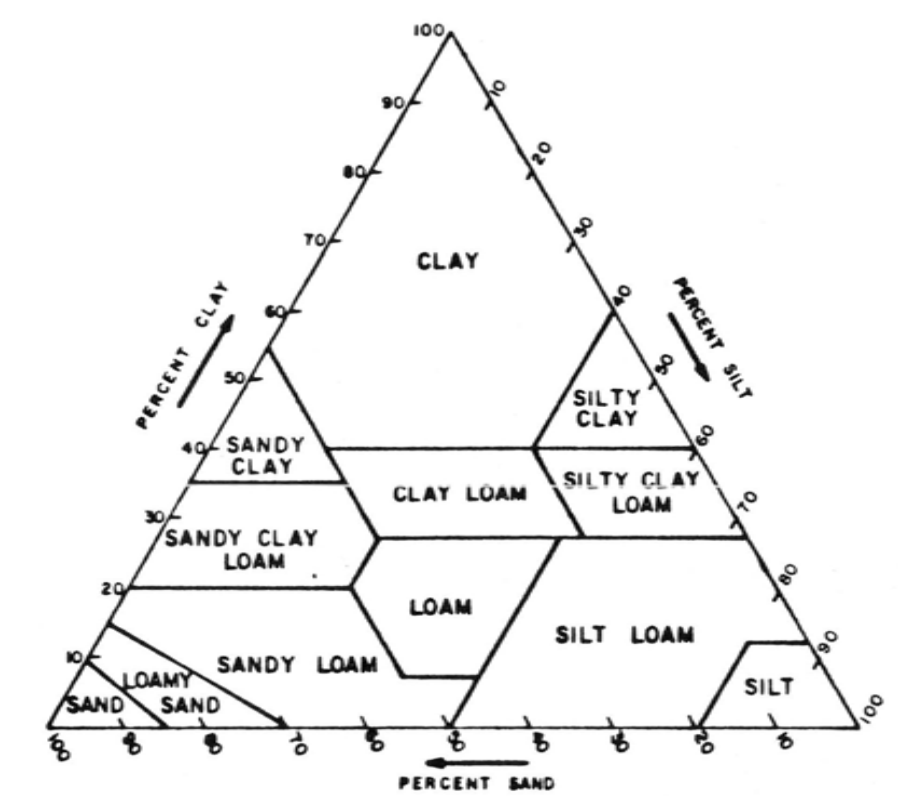

Color: Standard Munsell color names are given for the dominant color of the moist soil and for prominent mottles.

Plasticity: estimated from the strength of air dried sample and toughness of thread formed when soil is rolled at the plastic limit (Sowers and Sowers, 1970).

$\begin{array}{ll}\text { plasticity } & \text { dry strength } \\ \text { non plastic } & \text { vilow } \\ \text { slightly } & \text { sight } \\ \text { medium } & \text { medium } \\ \text { highly } & \text { high }\end{array}$

field test

falls apart easily easily crushed friable with difficulty cannot crush with fingers

\begin{tabular}{|c|c|c|c|}
\hline \multicolumn{4}{|c|}{ DESCRIPTION } \\
\hline \multicolumn{4}{|c|}{$\begin{array}{l}\text { Relative density of sand and consistency of clay is cor- } \\
\text { related with penetration resistance: (Terzaghi and Peck } \\
\text { 1948) }\end{array}$} \\
\hline blows/ft. & $\begin{array}{l}\text { relative } \\
\text { density }\end{array}$ & blows/ft. & consistency \\
\hline $0-4$ & v. loose & $<2$ & v. soft \\
\hline $4-10$ & loose & $2-4$ & soft \\
\hline $10-30$ & medium & $4-8$ & medium \\
\hline $30-50$ & dense & $8-15$ & stiff \\
\hline$>50$ & v. dense & $\begin{array}{l}15-30 \\
>30\end{array}$ & $\begin{array}{l}\text { v. stiff } \\
\text { hard }\end{array}$ \\
\hline
\end{tabular}

CL, MH, etc.: Unified Soil Classification Group Symbol (U. S. Army Corps of Engineers, 1960)

Rock hardness: response to hand and geologic hamer: (Ellen et al., 1972)

hard - hammer bounces off with solid sound

firm - hammer dents with thud, pick point dents or penetrates slightly

soft - pick point penetrates

friable material can be crumbled into individual grains by hand.

Fracture spacing: (Ellen et al., 1972)

$\begin{array}{lll}\frac{\mathrm{cm}}{0-1} & \frac{\text { in }}{0-1 / 2} & \text { fracture spacing } \\ 1-5 & 1 / 2-2 & \text { close } \\ 5-30 & 2-12 & \text { moderate } \\ 30-100 & 12-36 & \text { wide } \\ >100 & >36 & v \text {. wide }\end{array}$

Weathering: (Actron-Blume-Atkinson, 1965)

Fresh: no visible signs of weathering

slight: no visible decomposition of minerals, slight discoloration

Moderate: slight decomposition of minerals and disintegration of rock, deep and thorough discoloration

Decomposed: extensive decomposition of minerals and complete disintegration of rock but original structure is preserved.

Figure 3. Definitions of terms used for descriptions of sedimentary deposits and bedrock materials. 


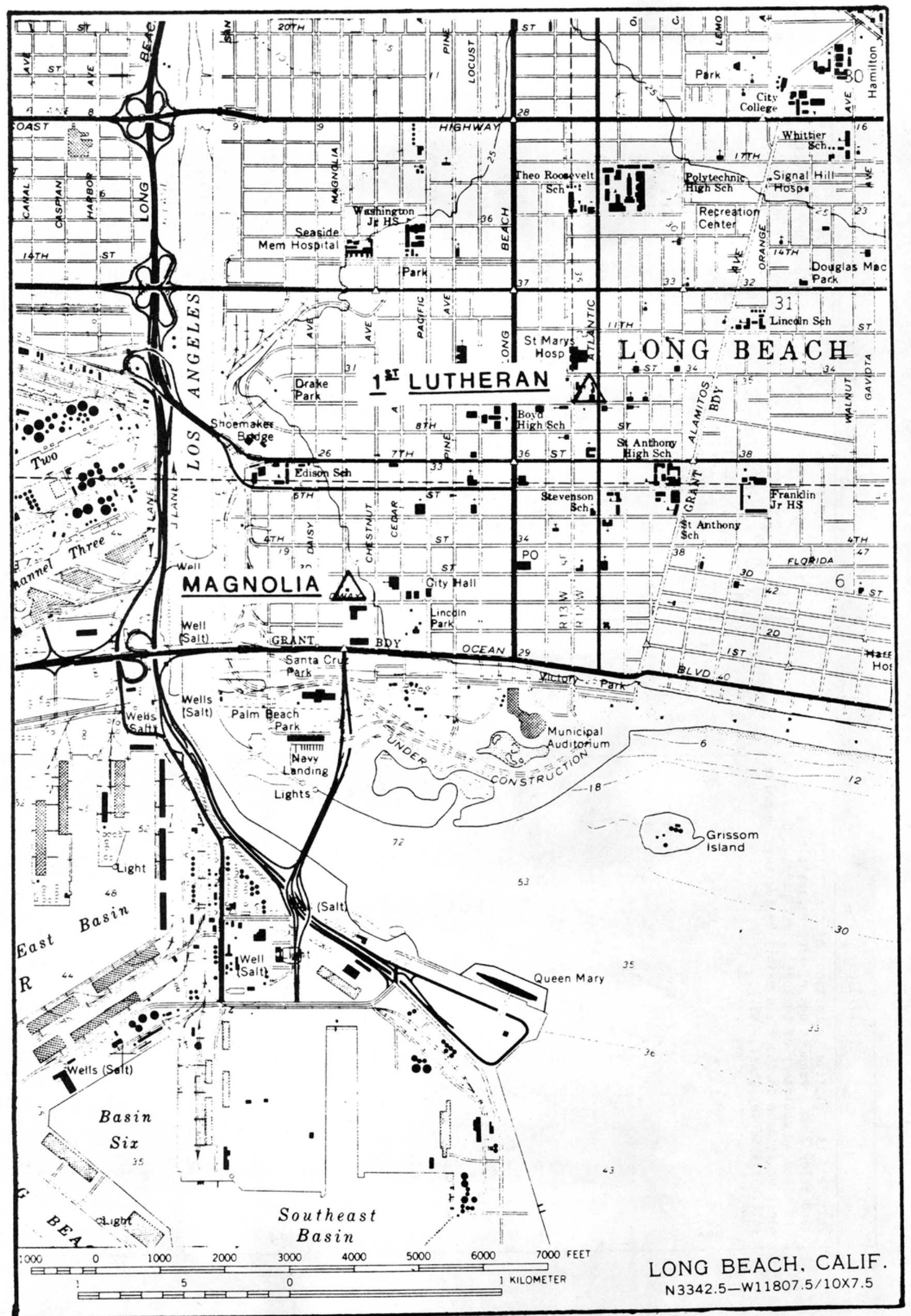

Figure 4 . 


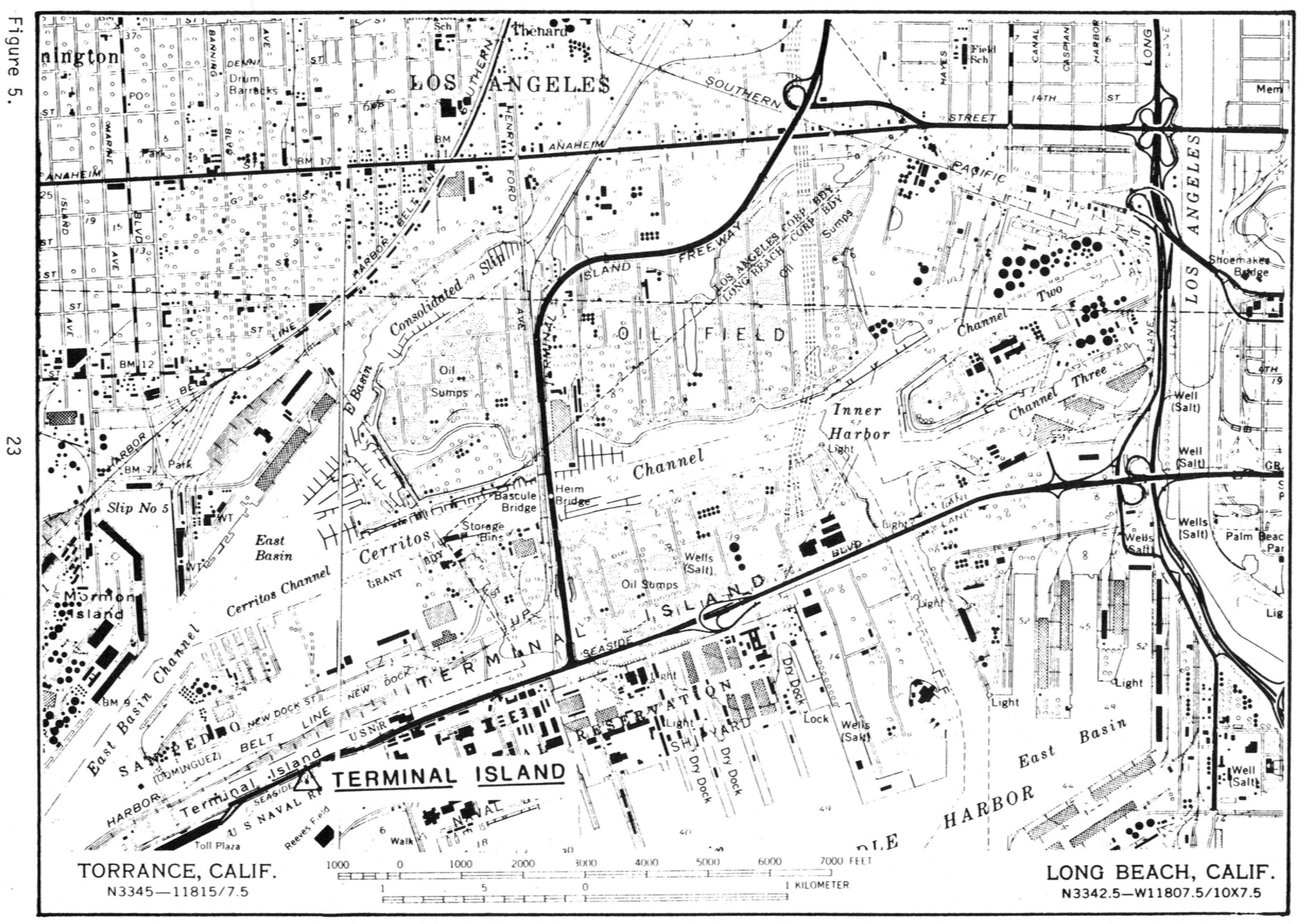




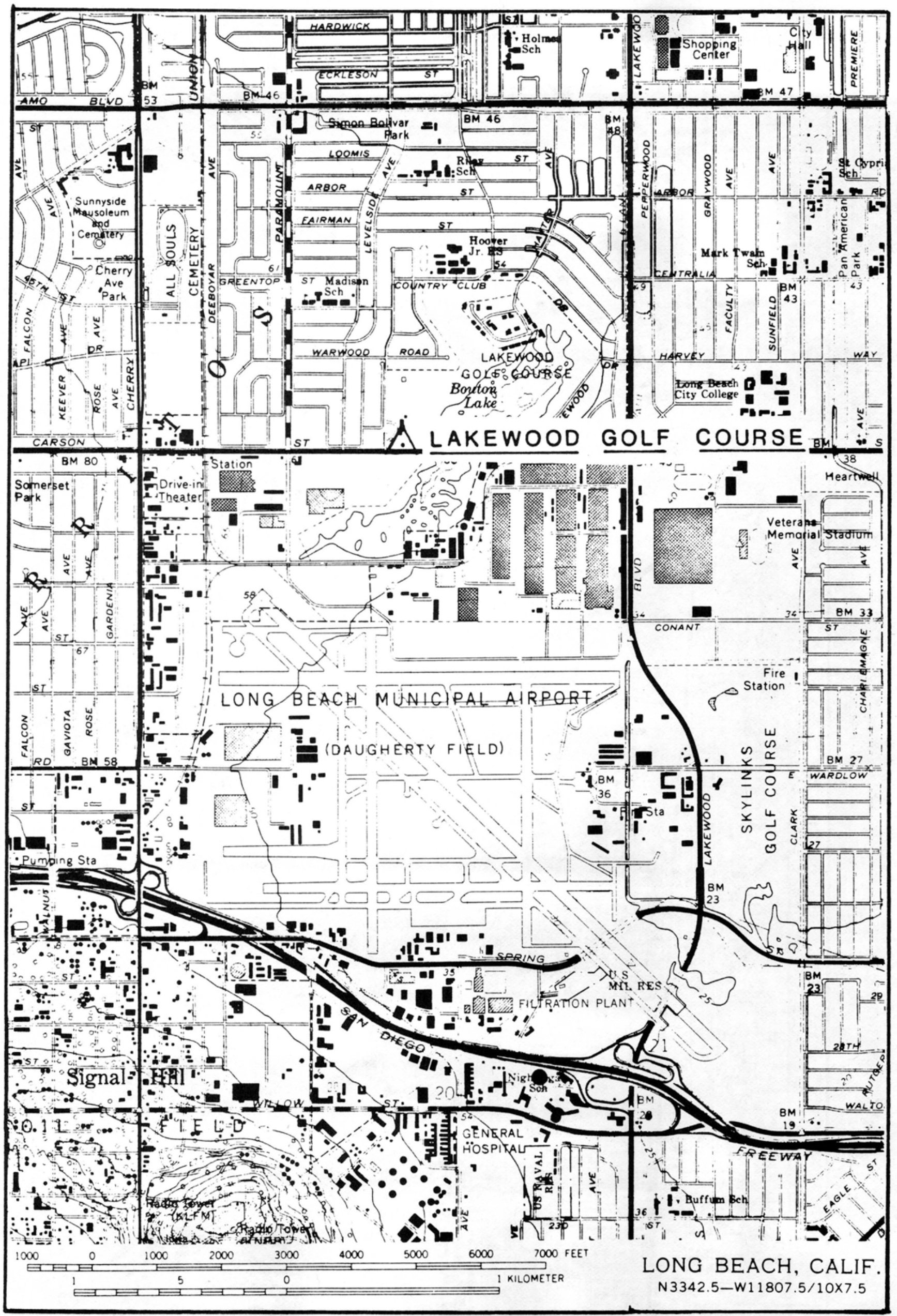

Figure 6 . 


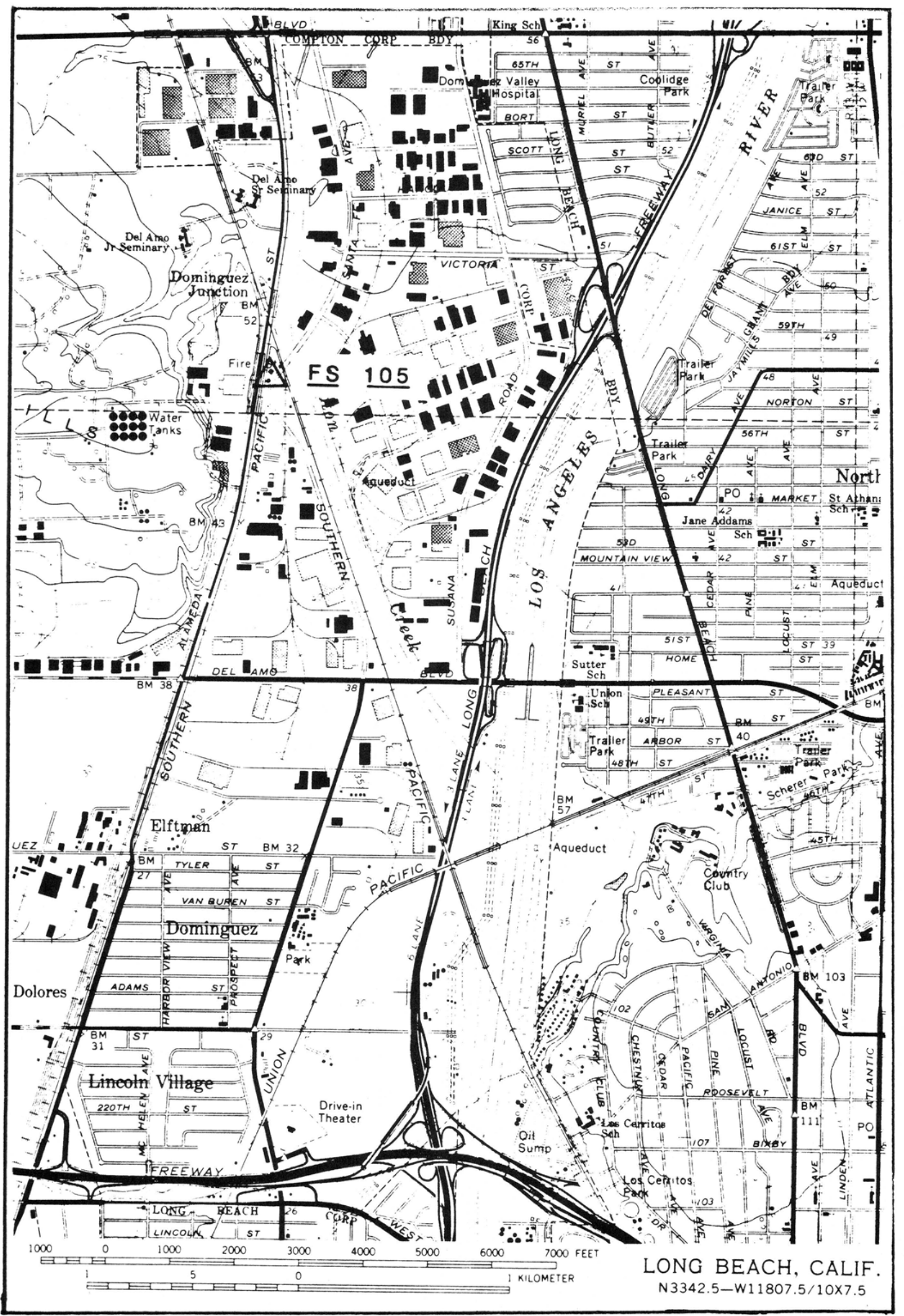




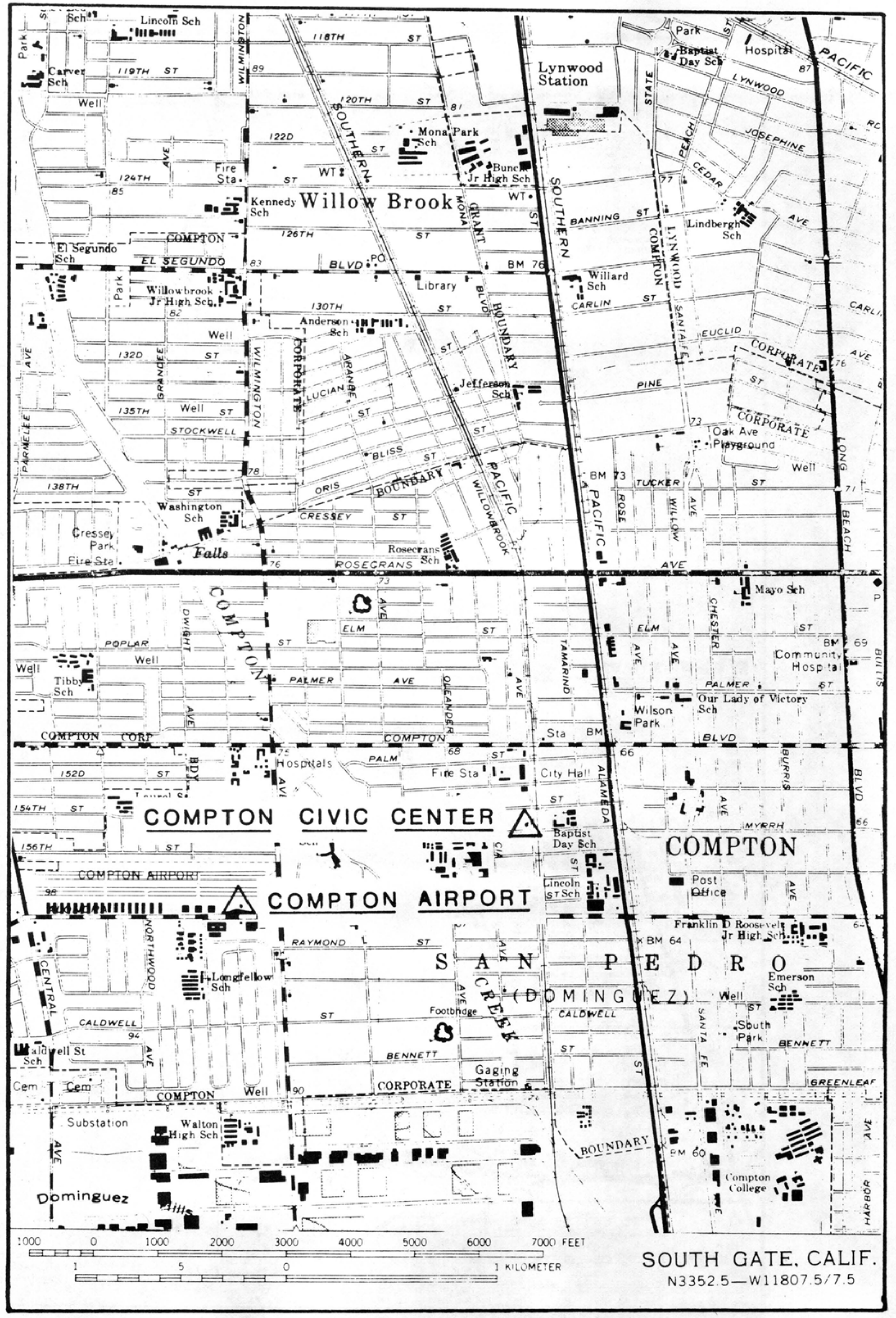

Figure 8. 


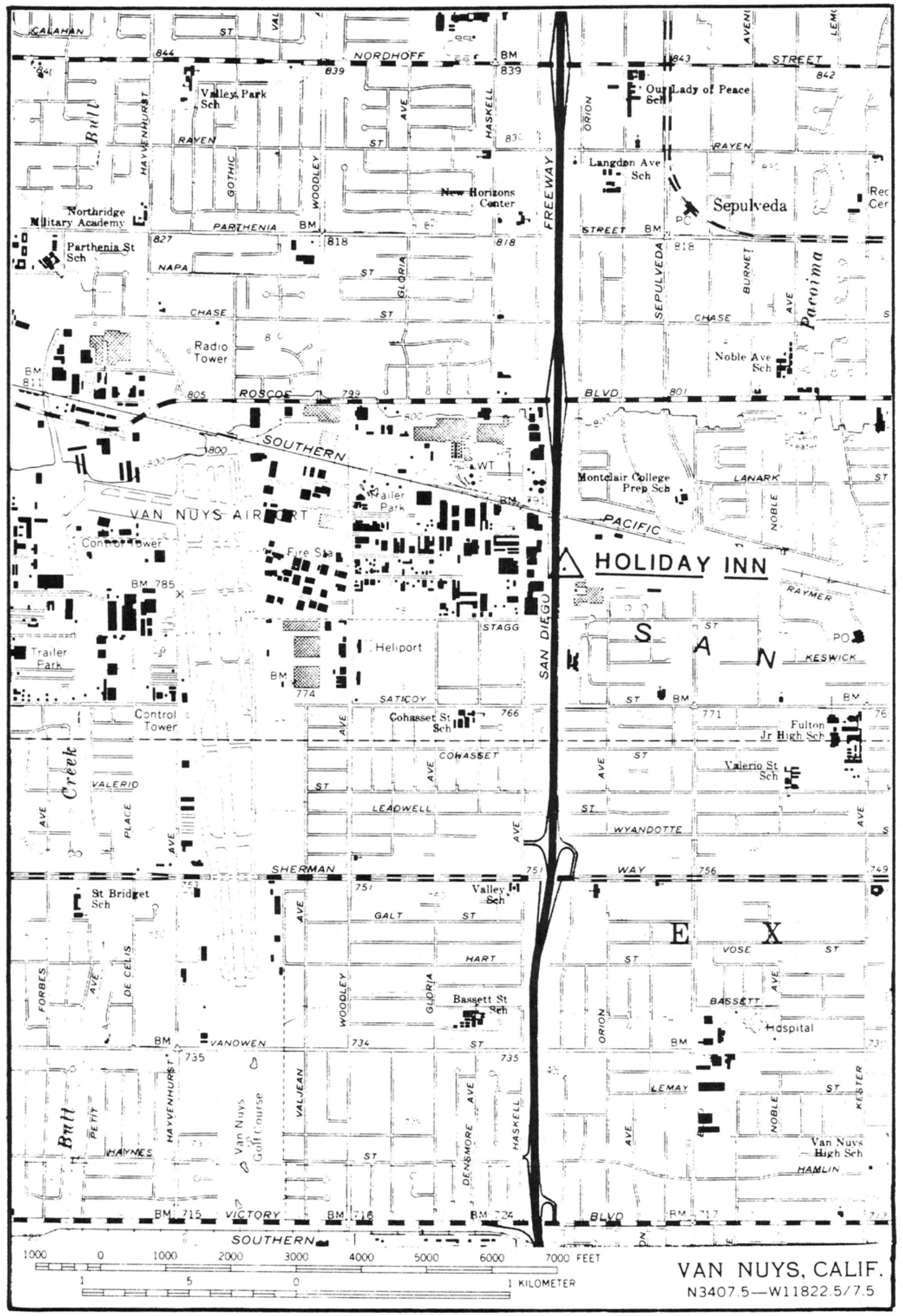

Figure 9. 


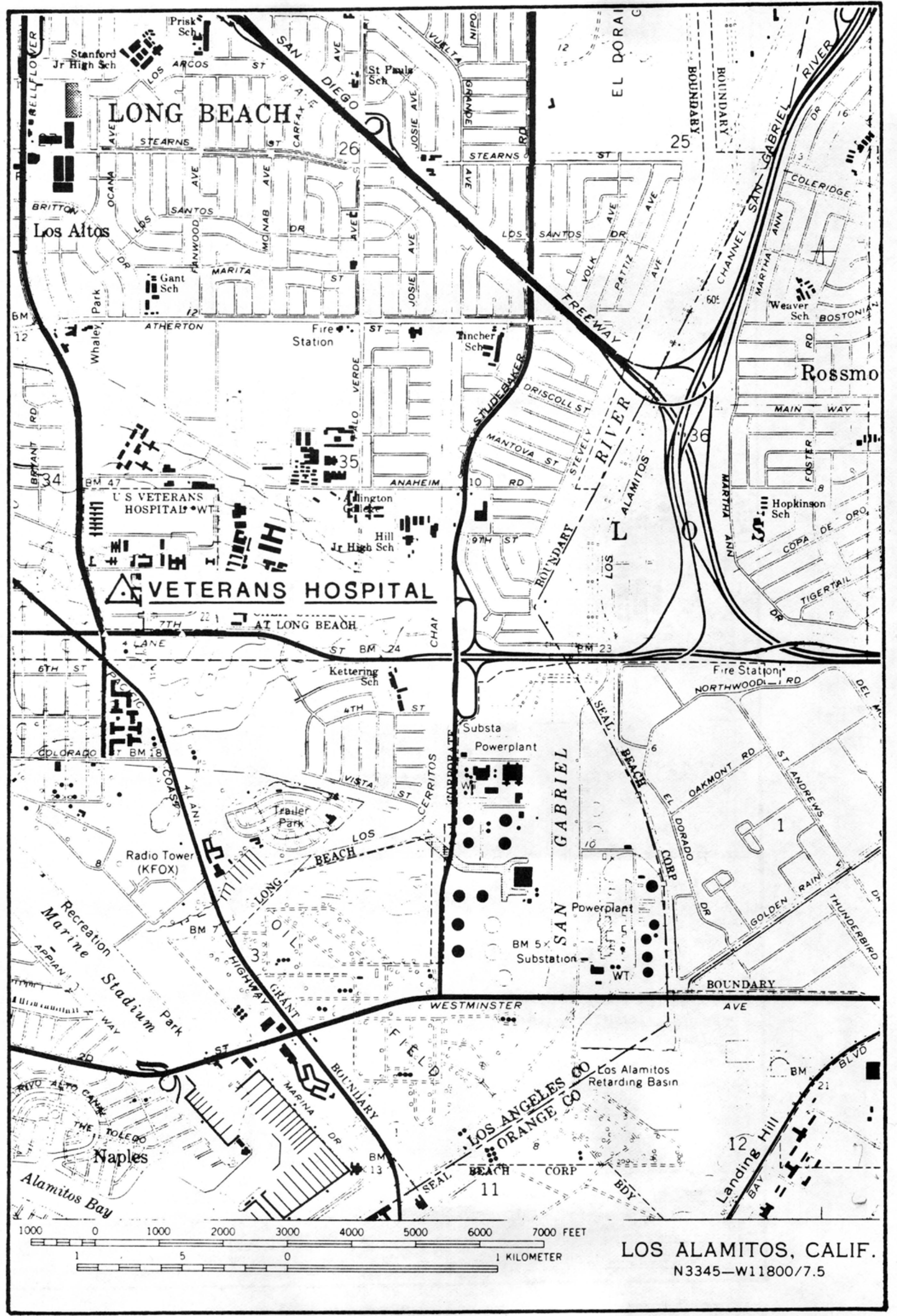

Figure 10. 


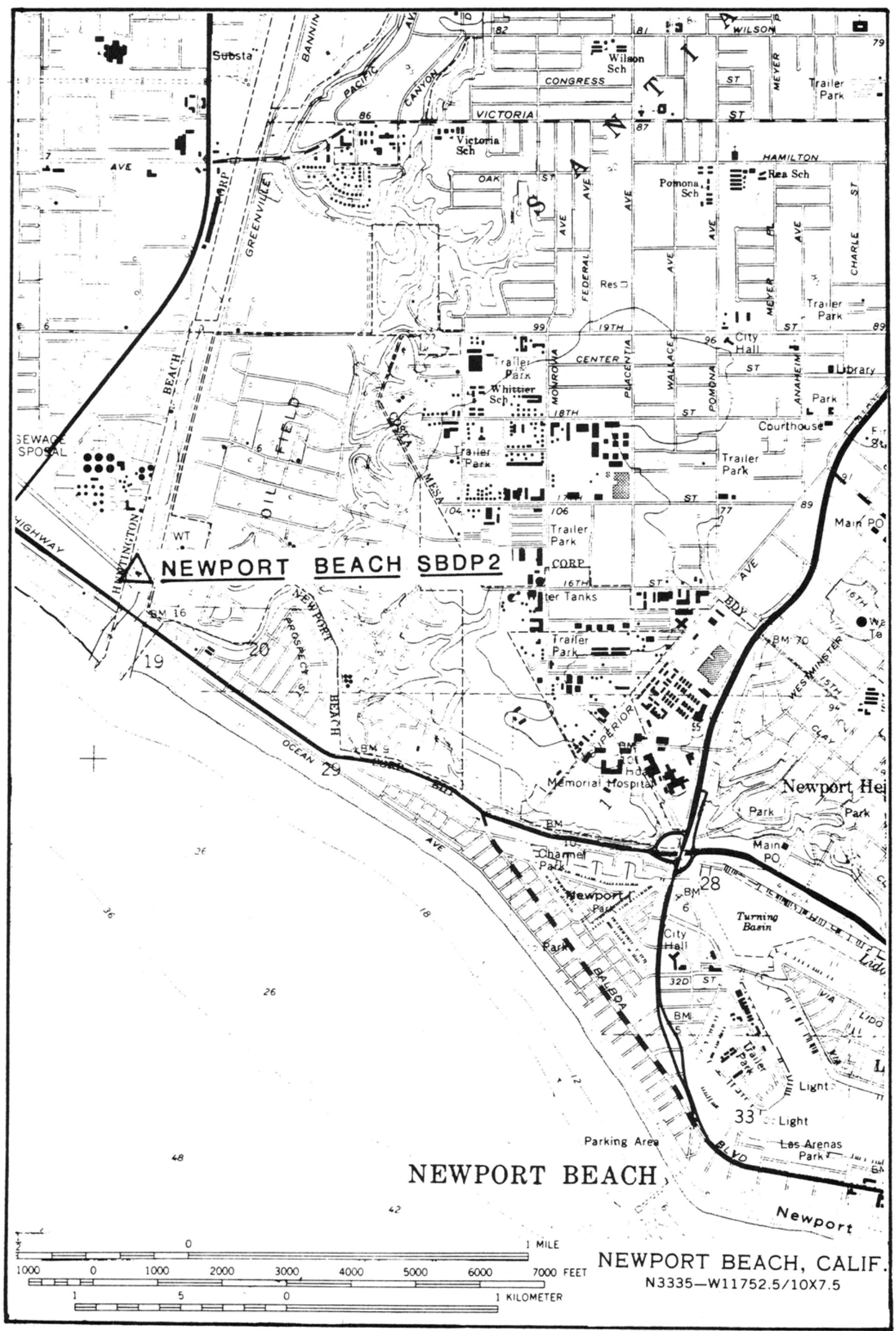

Figure 11.2 


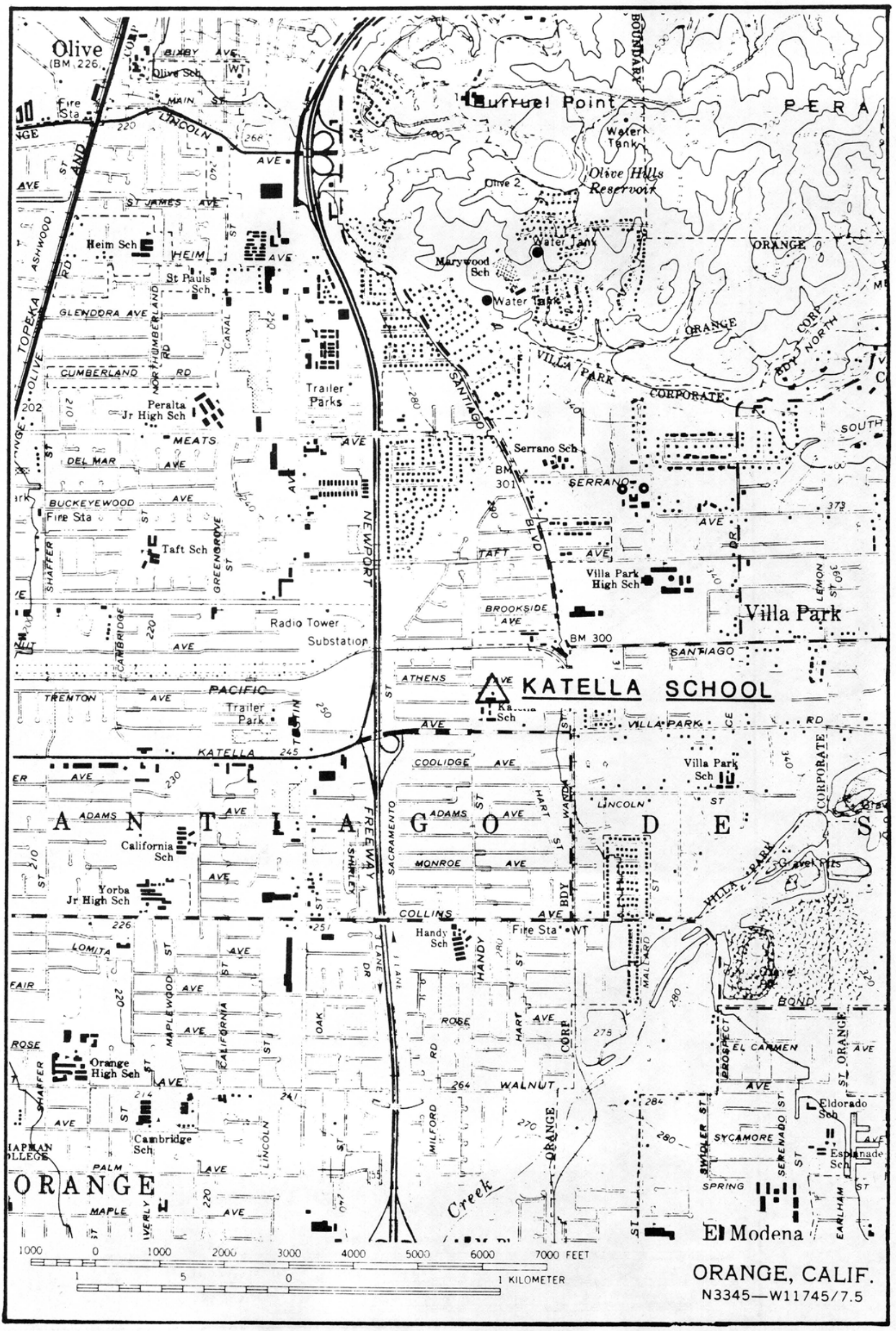




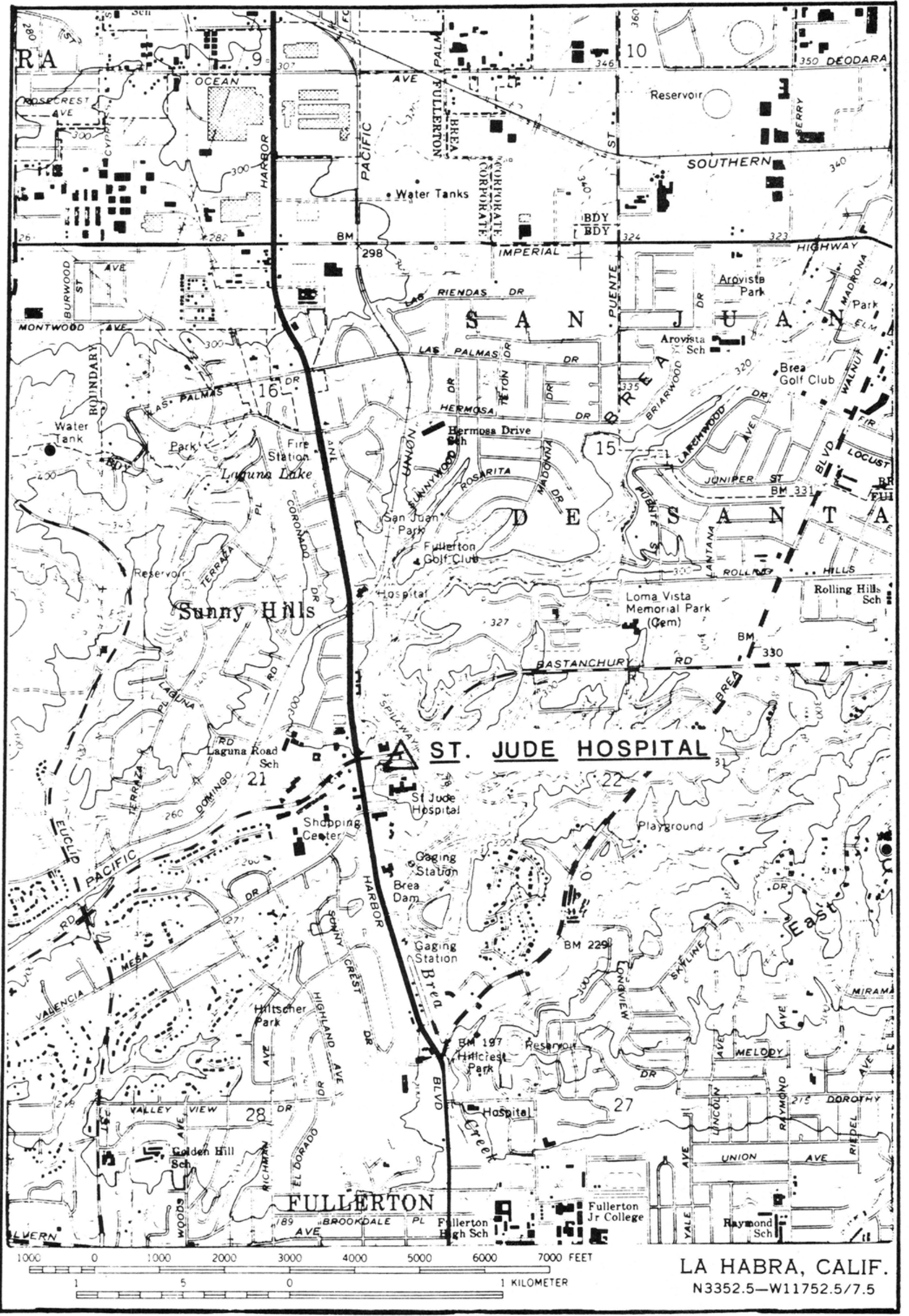




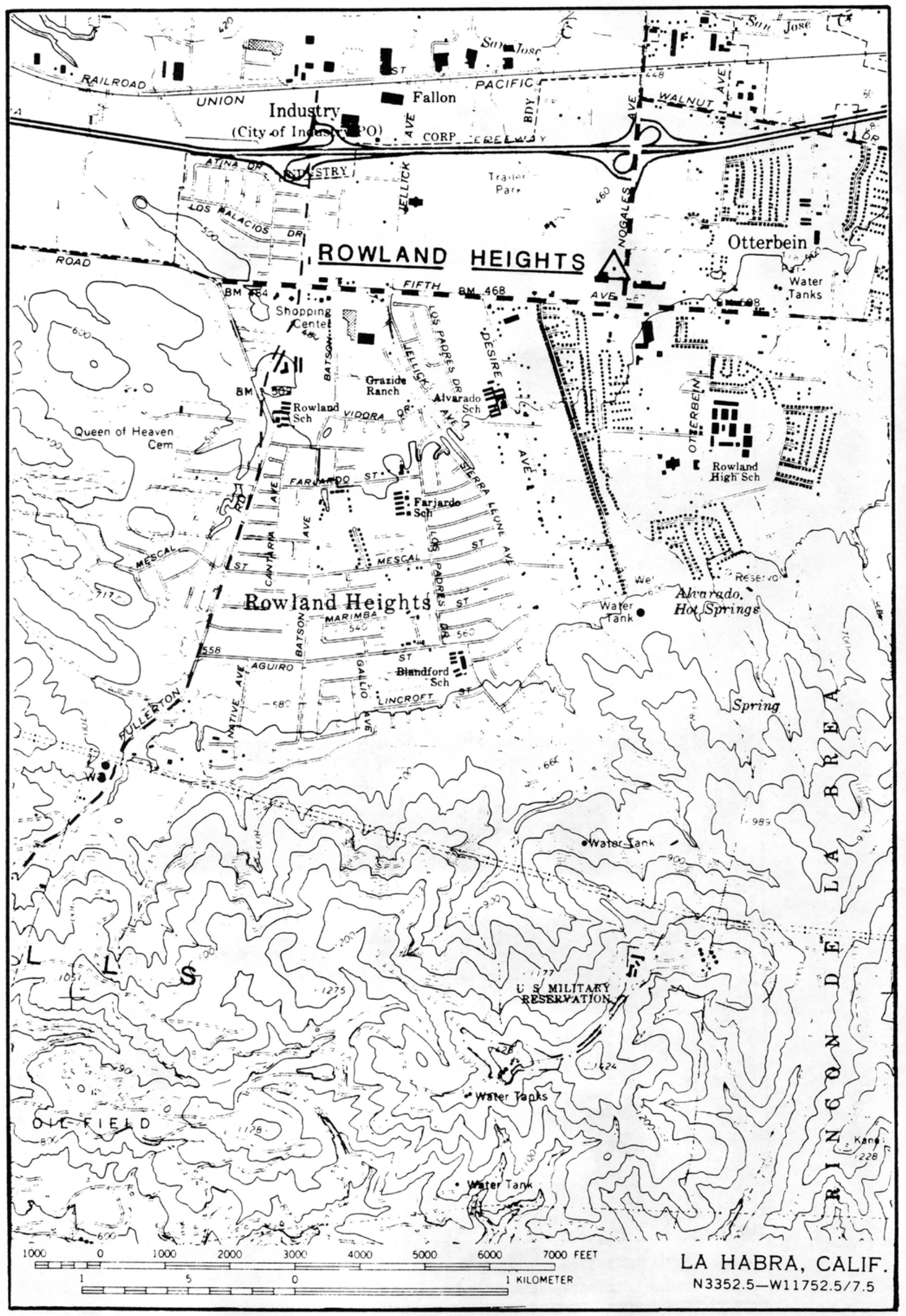




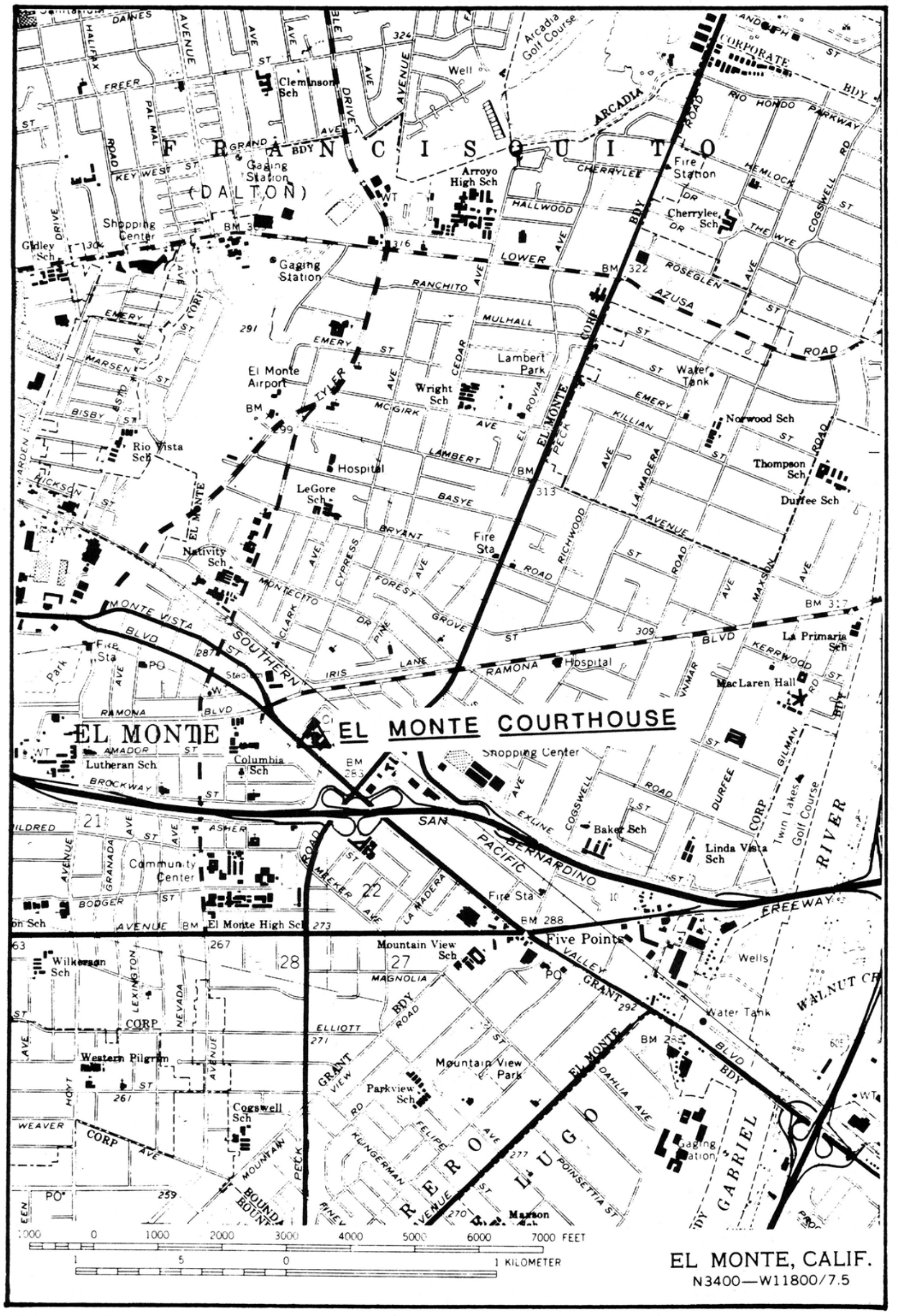

Figure 15. 


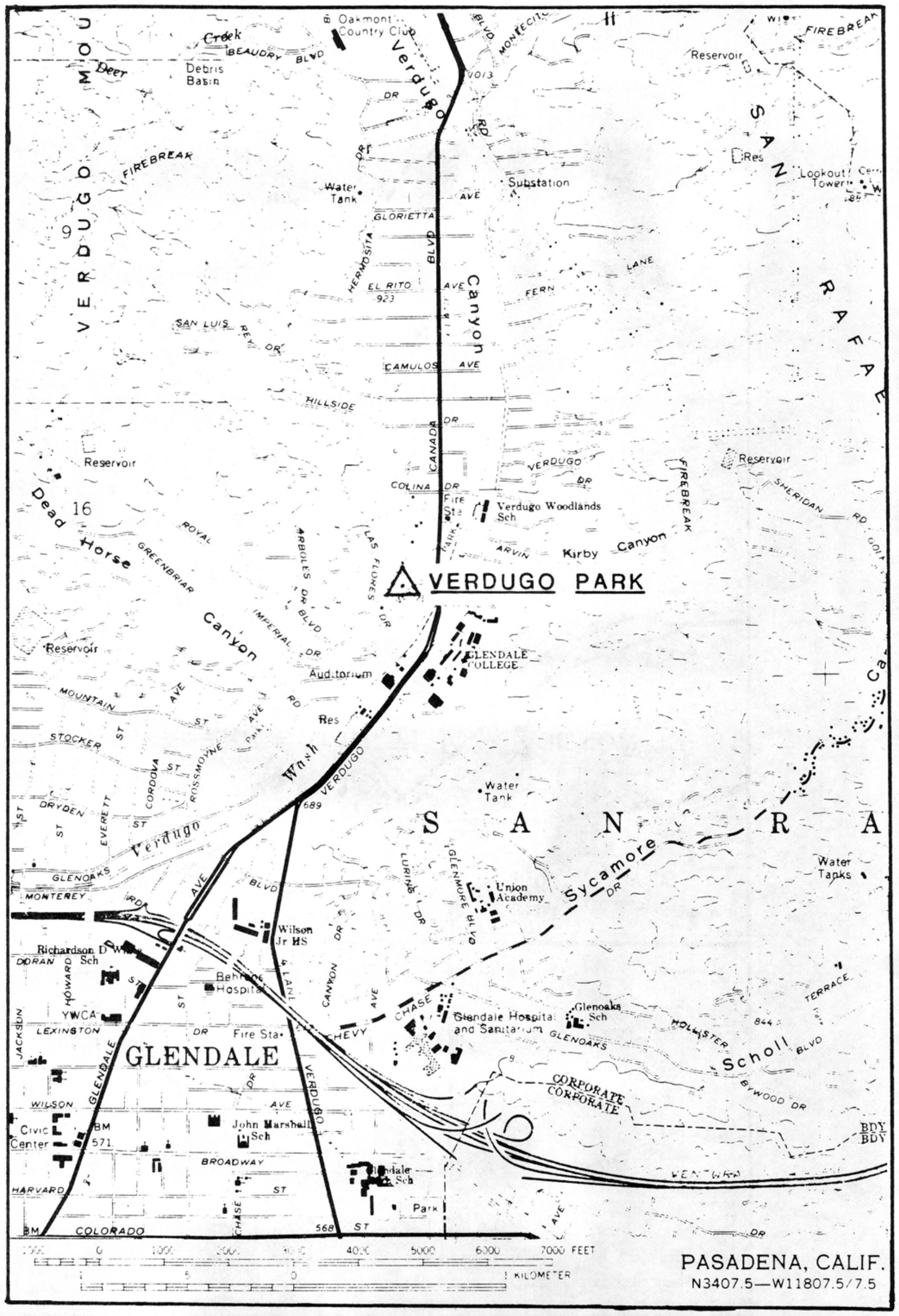

Figure 16. 


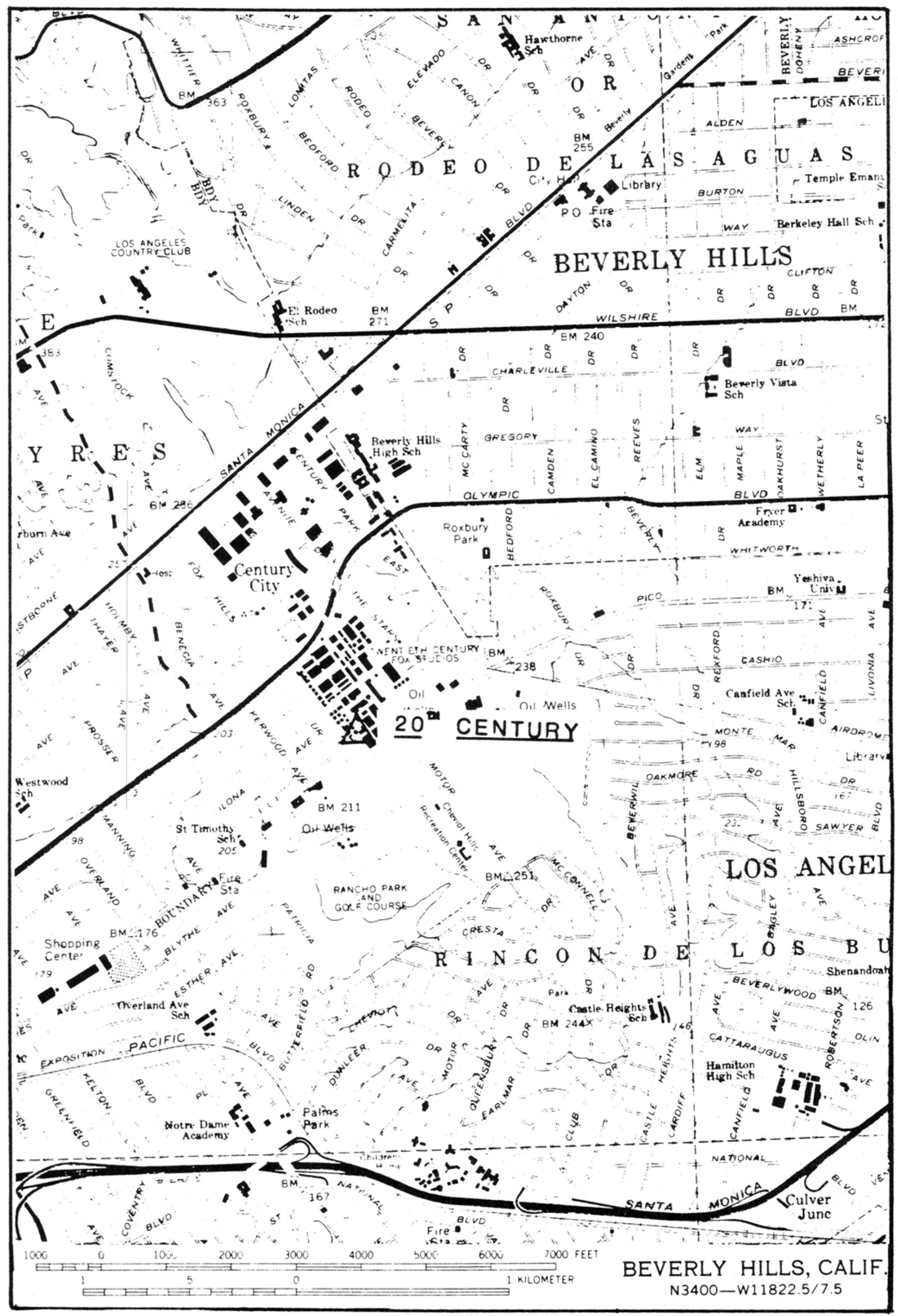

Figure 17. 


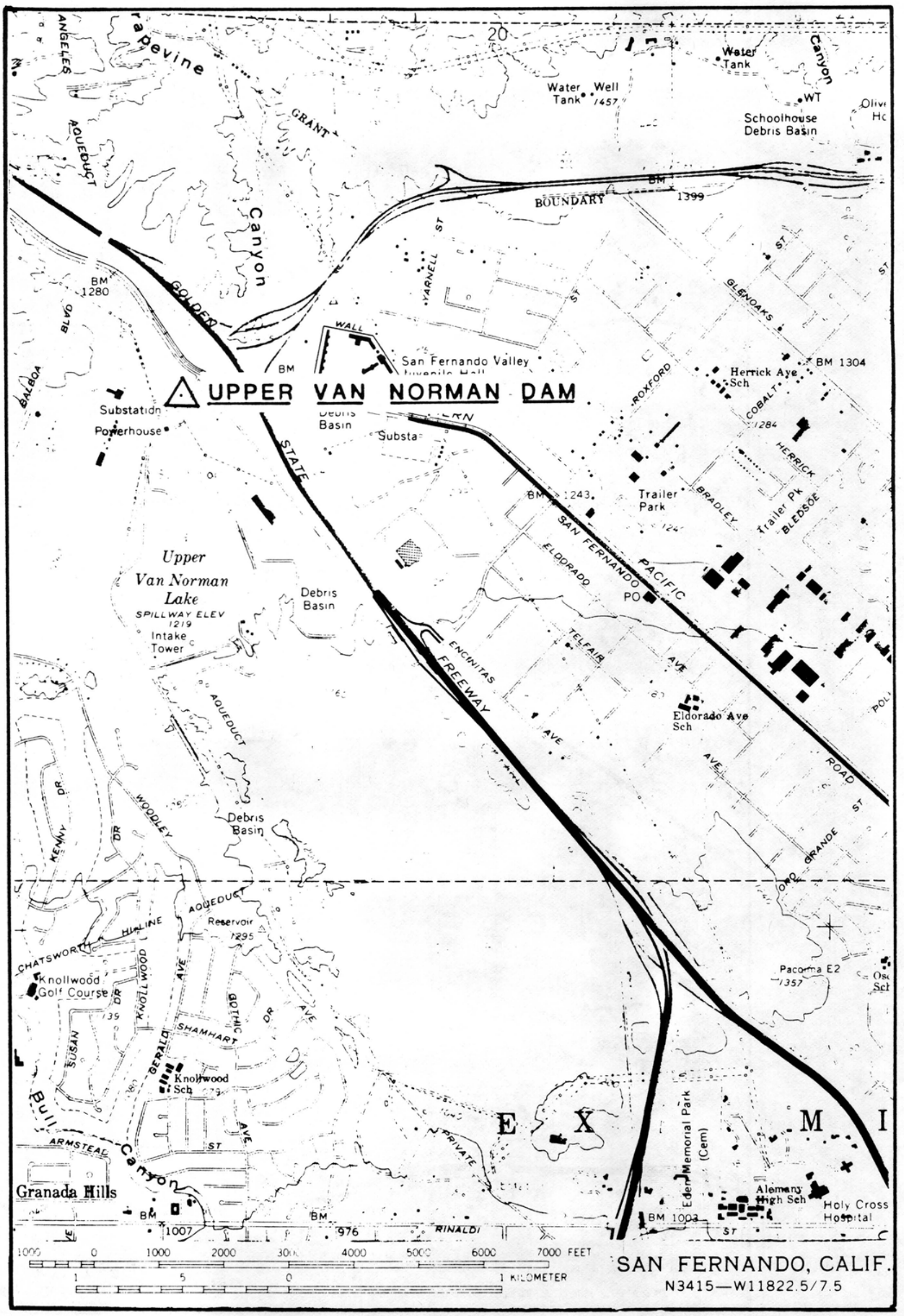

Figure 18. 


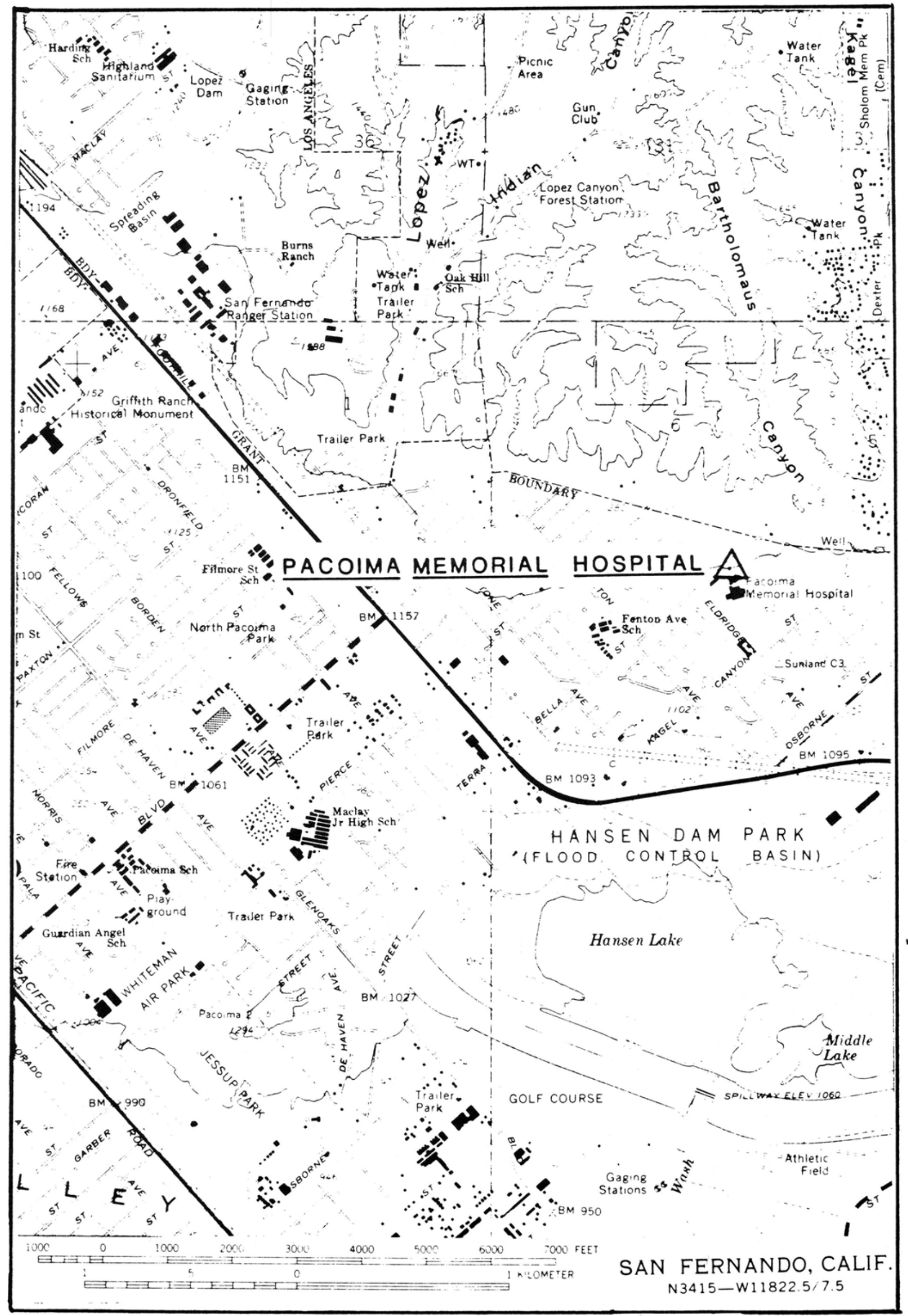

Figure 19. 


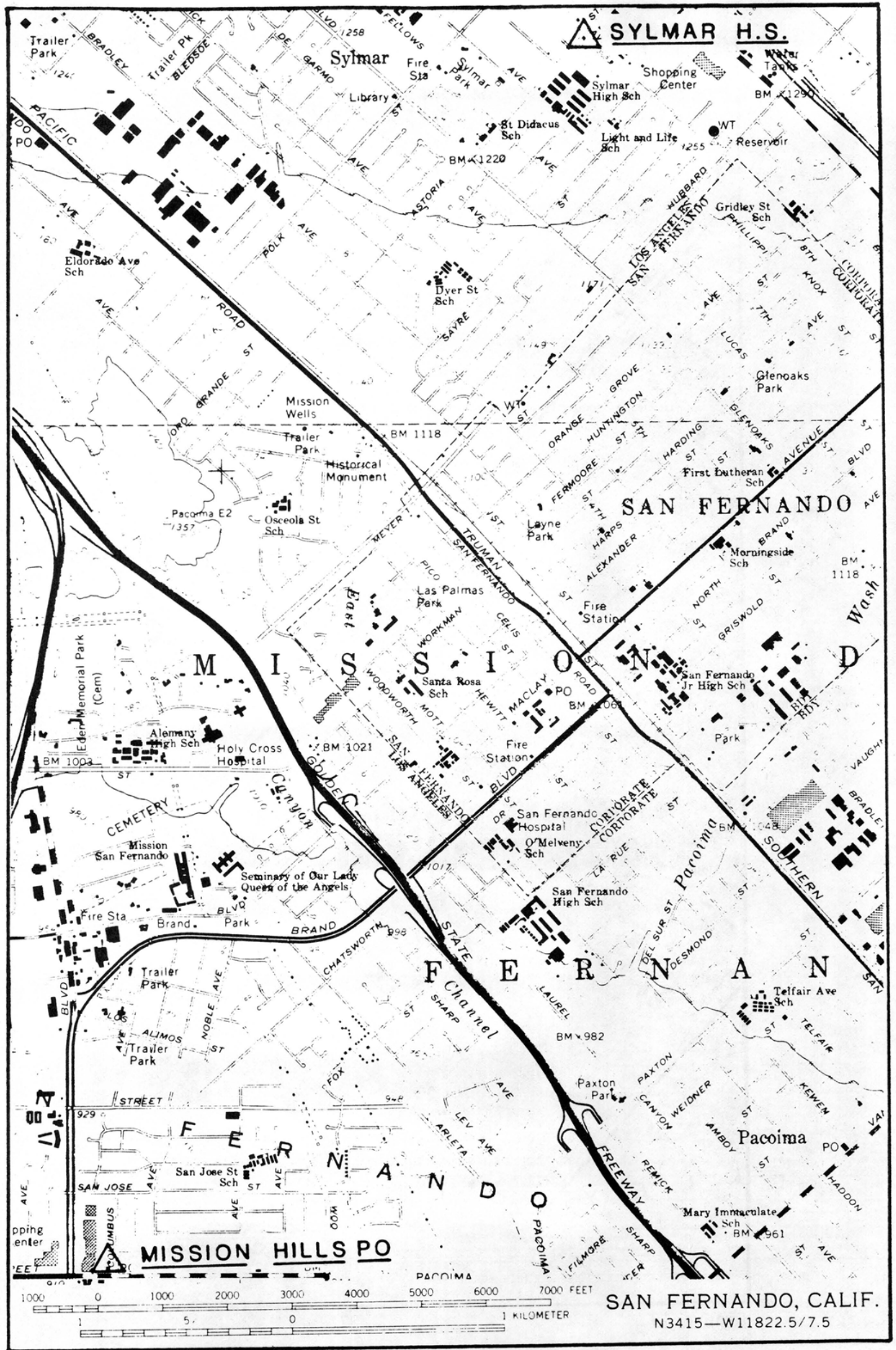




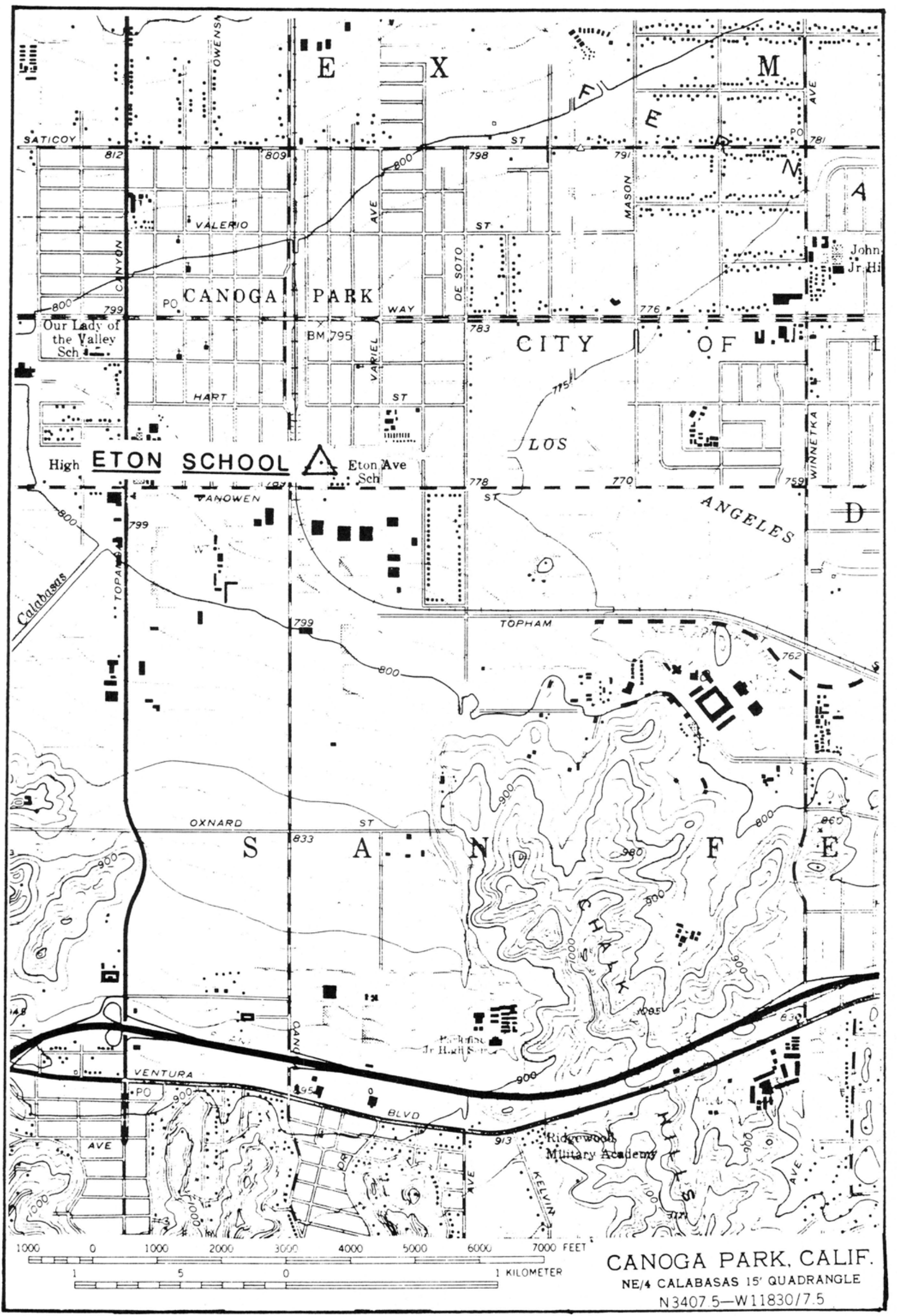




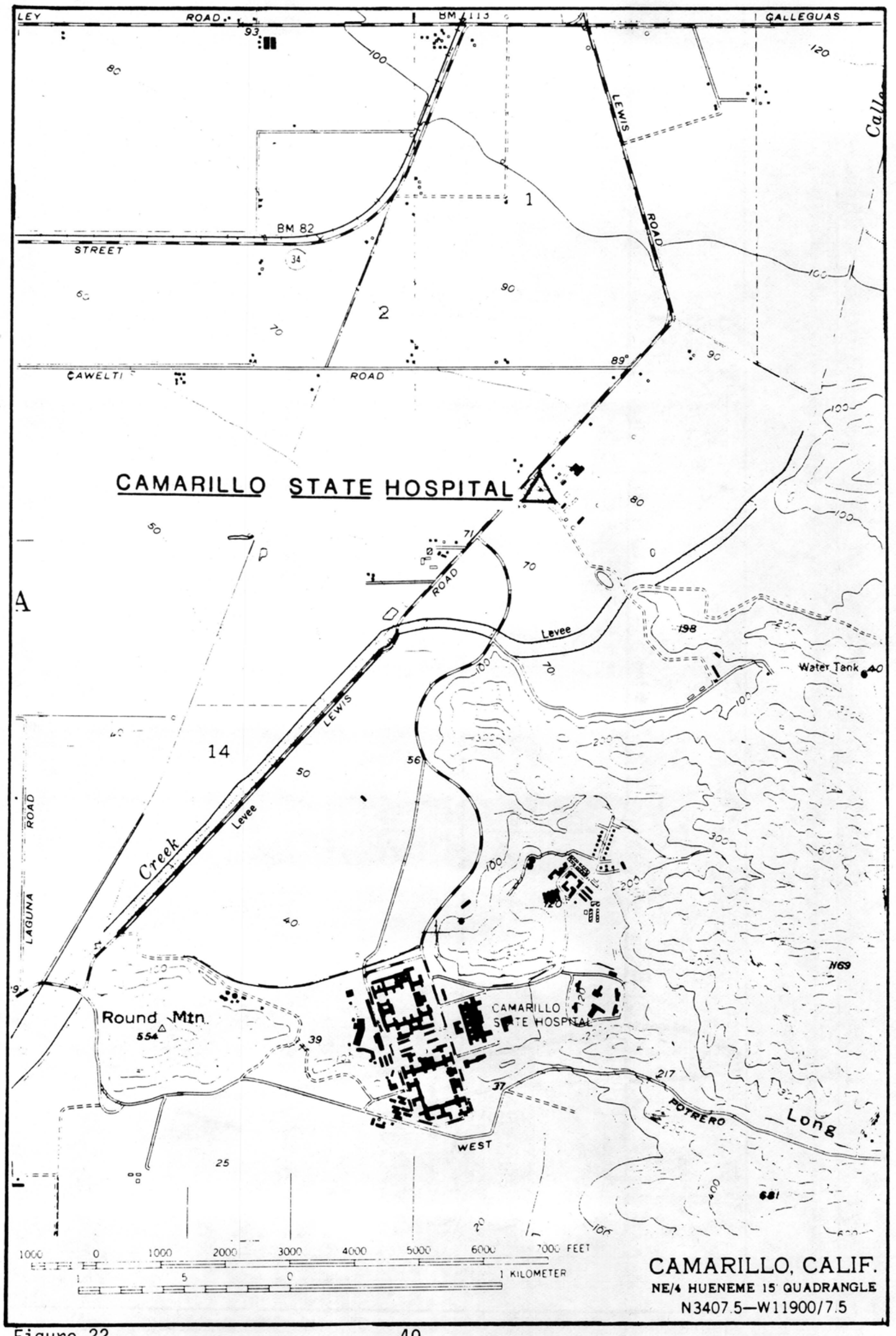

Figure 22. 


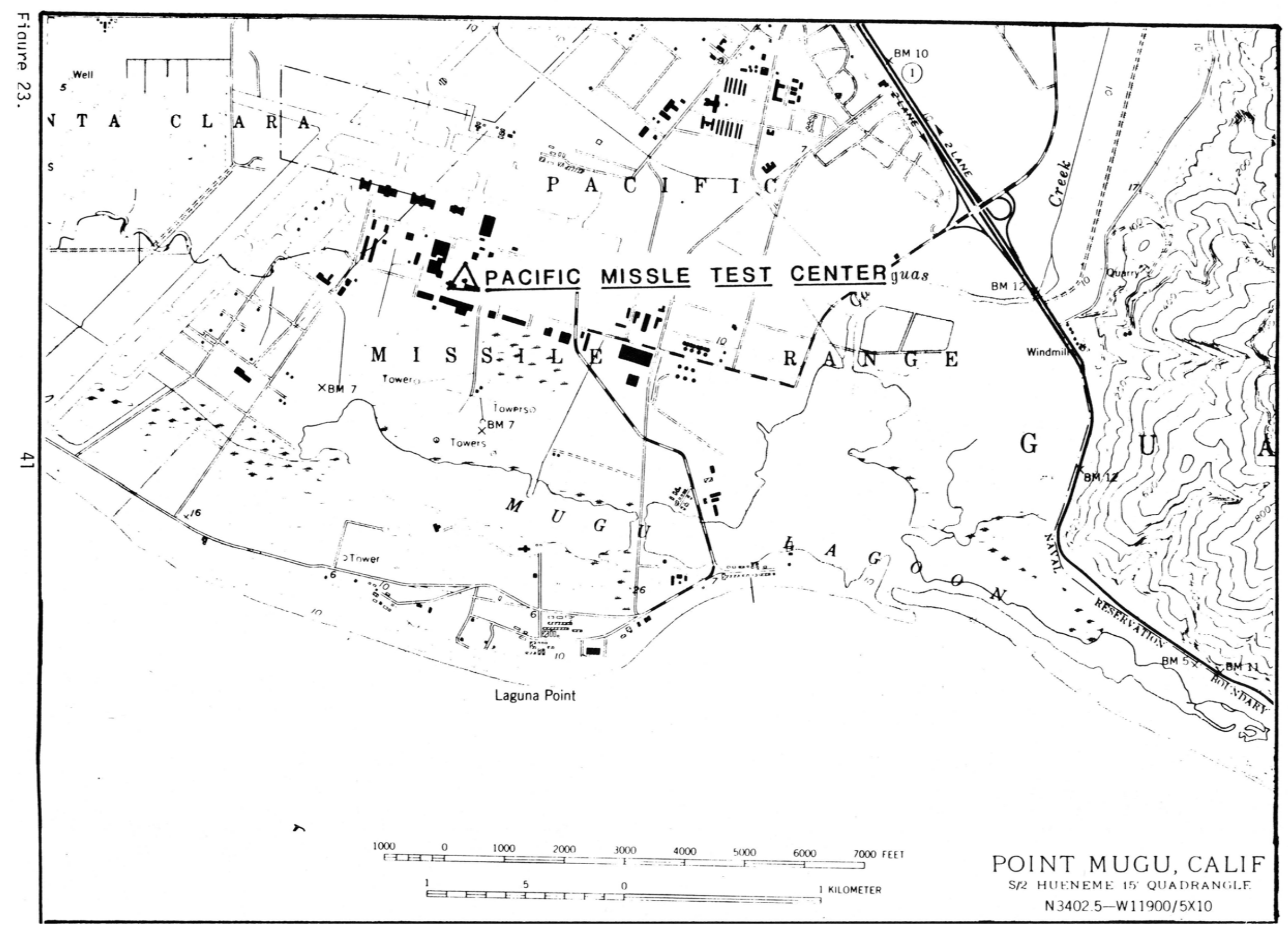




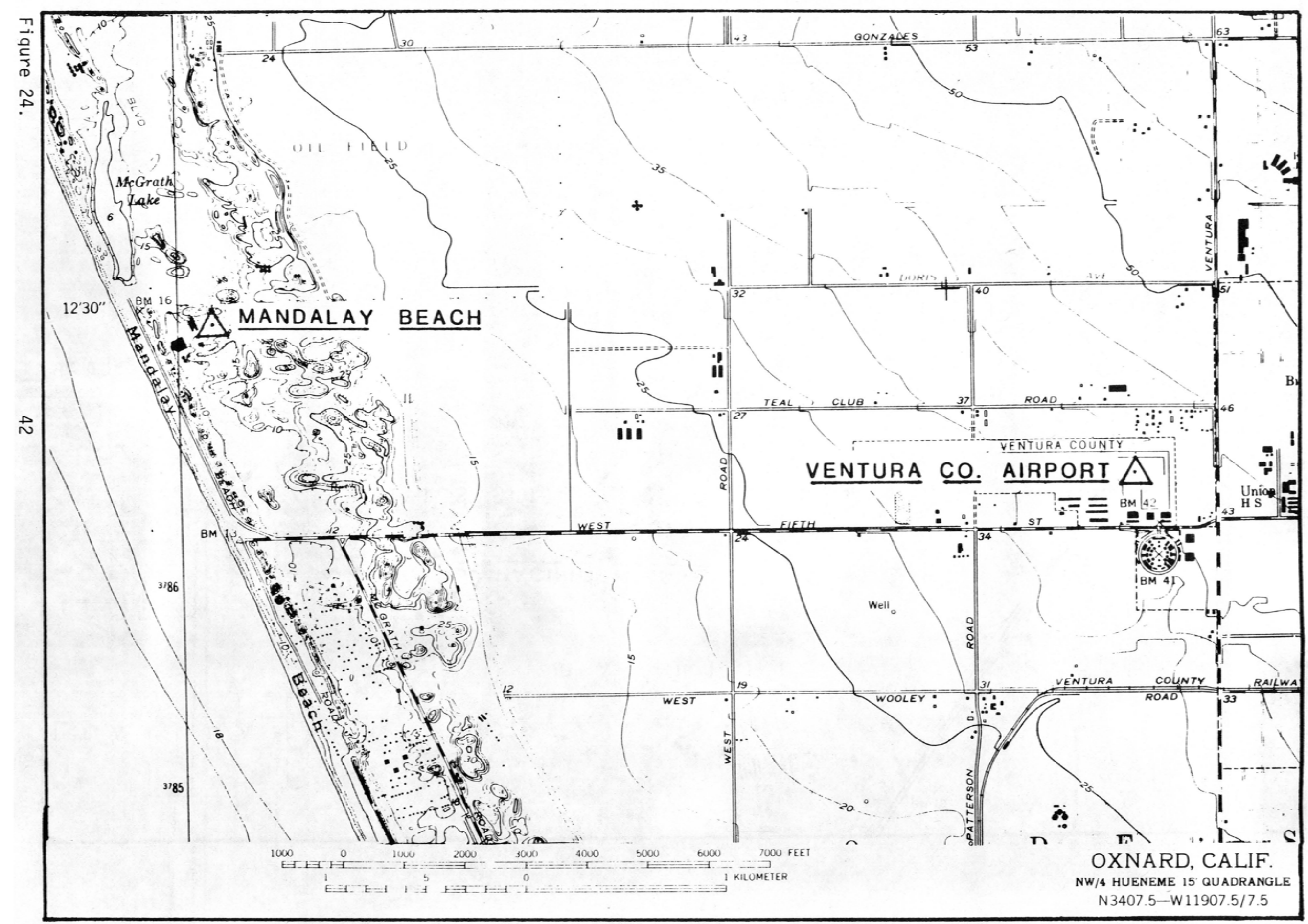




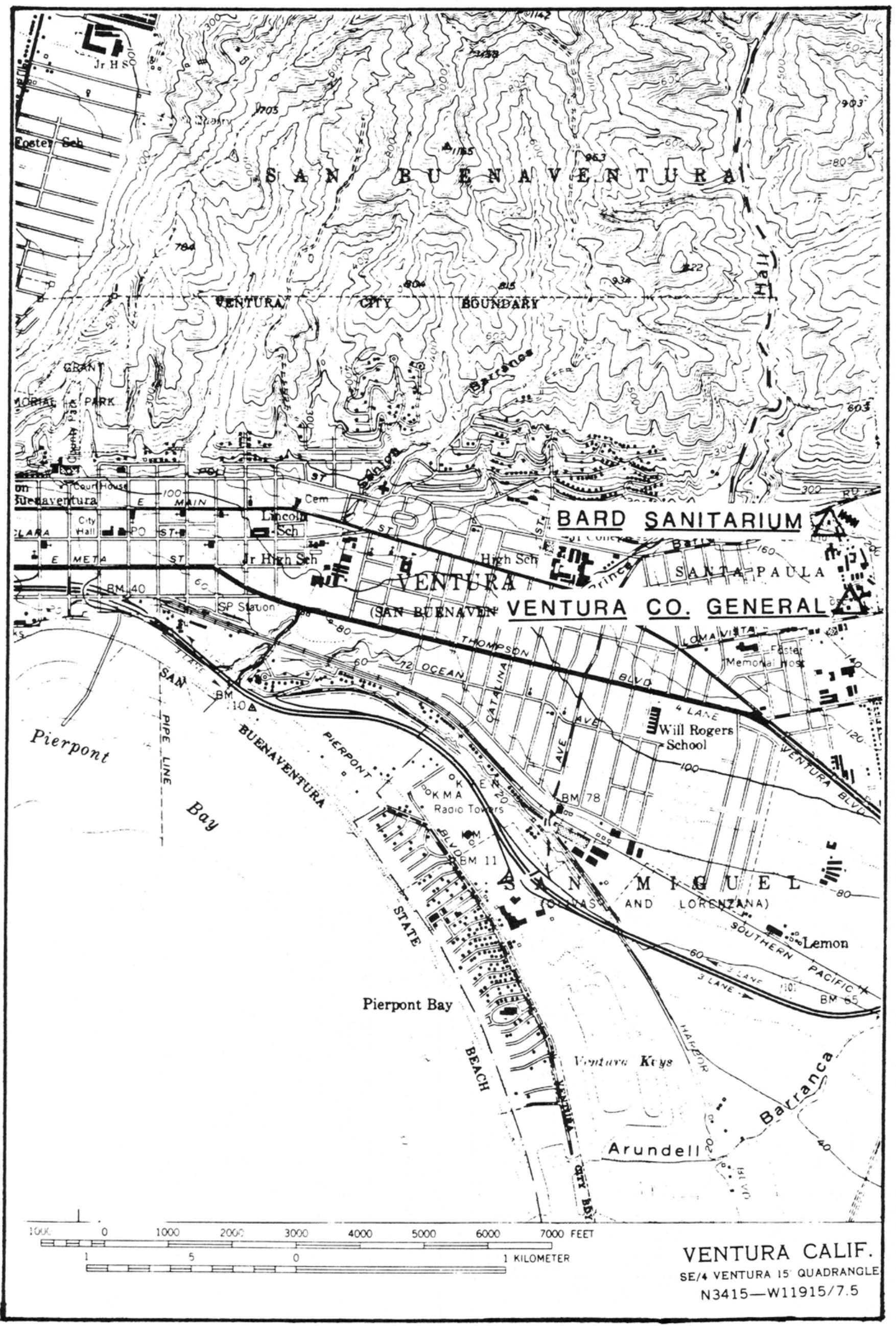




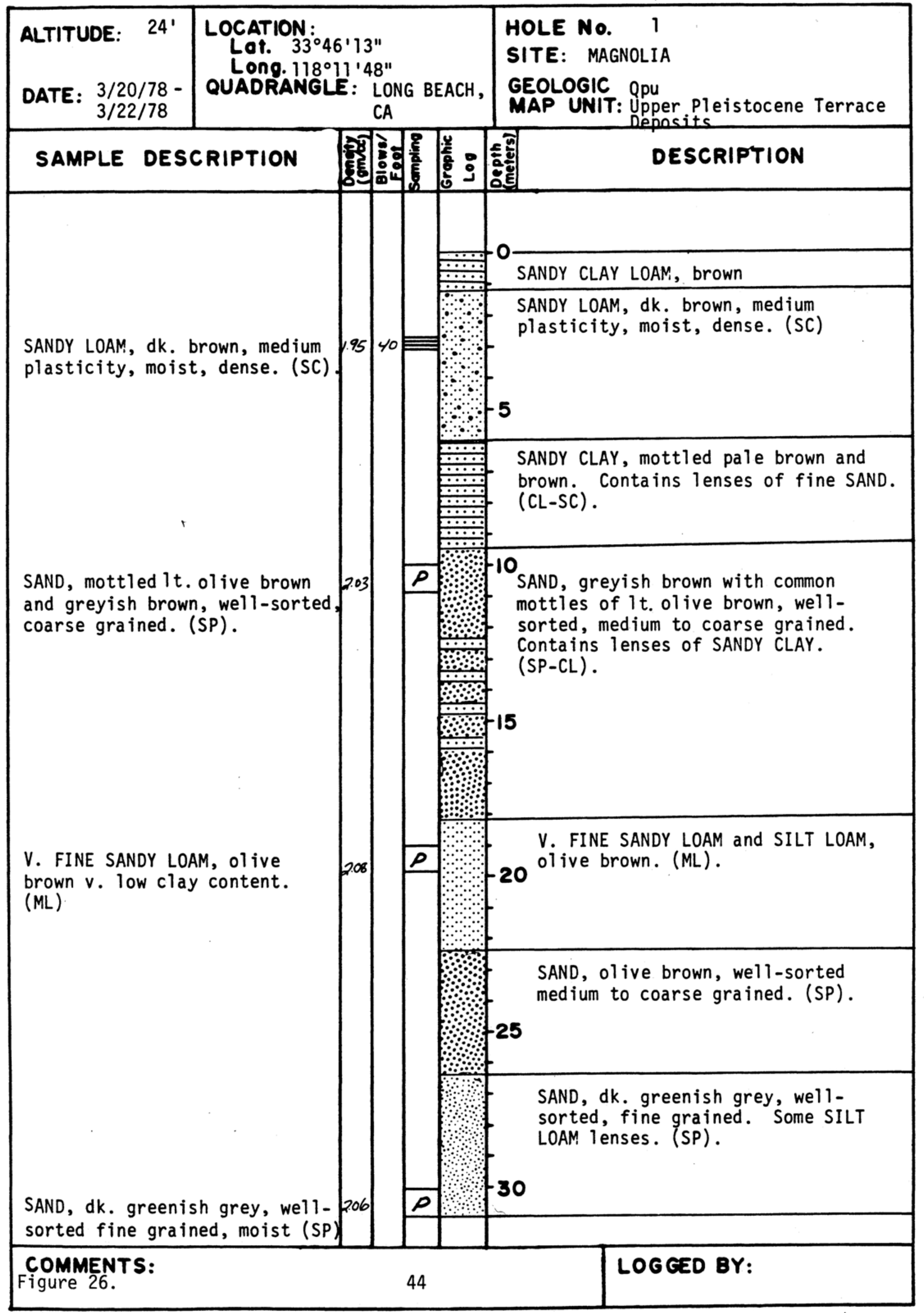




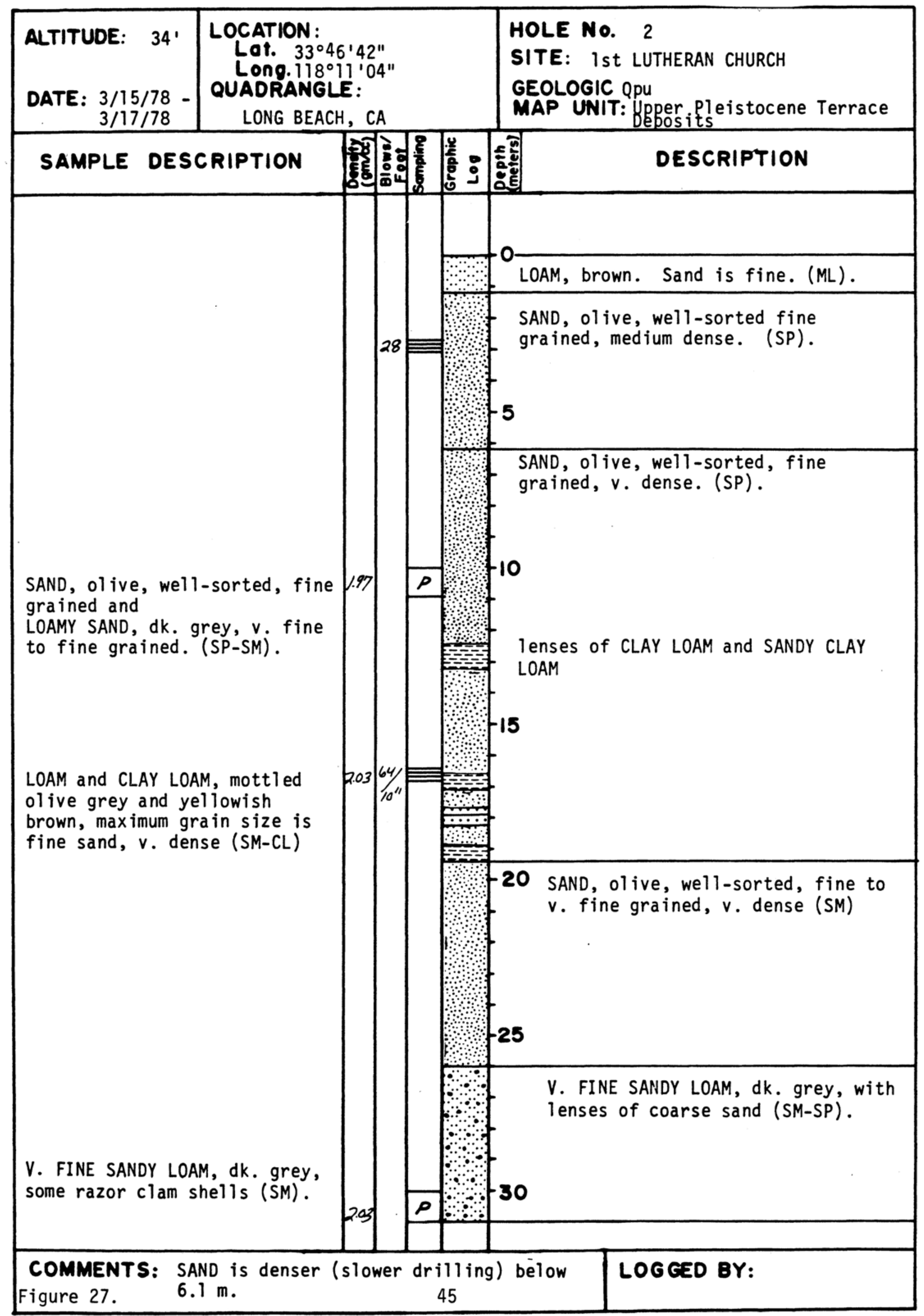




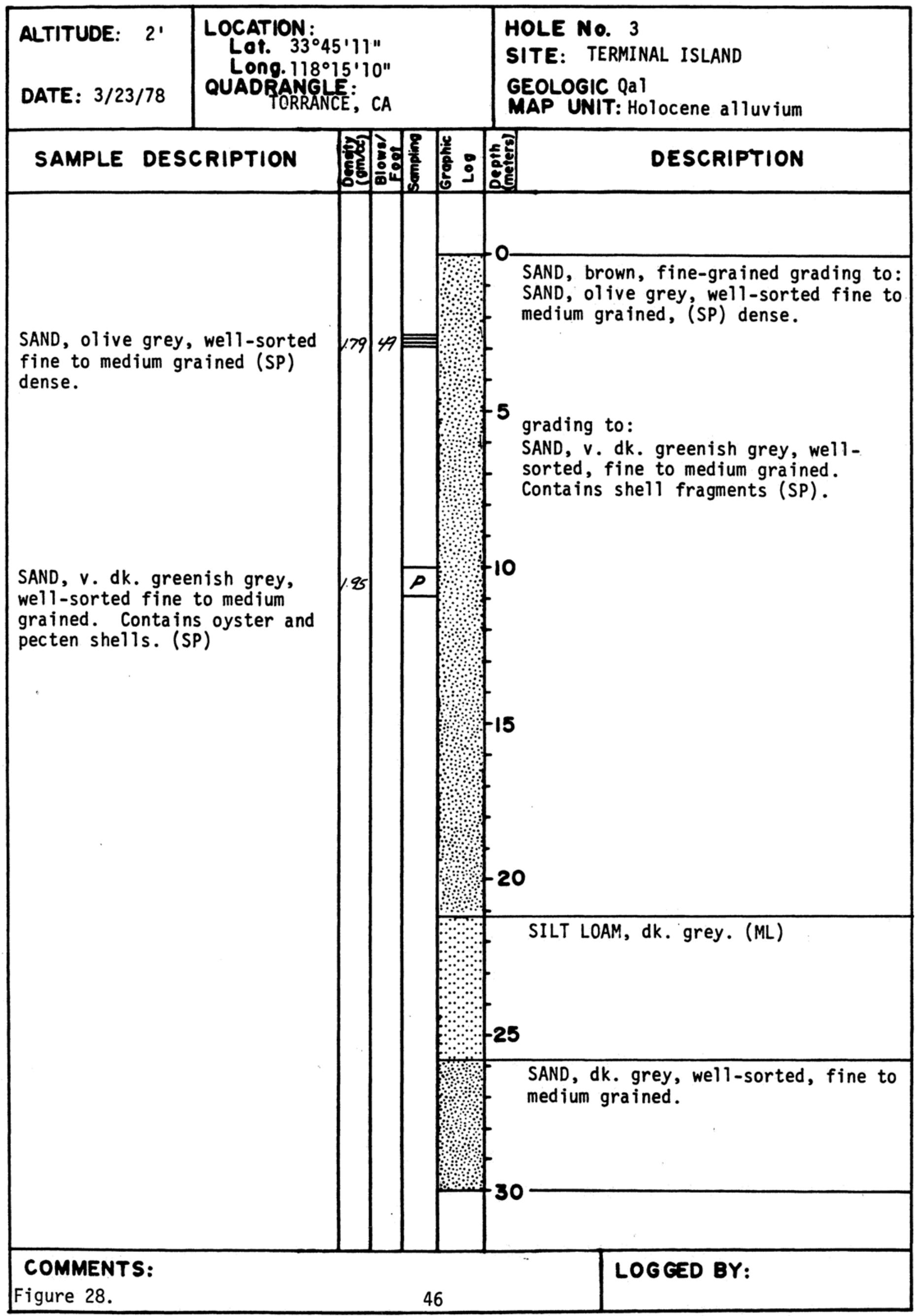




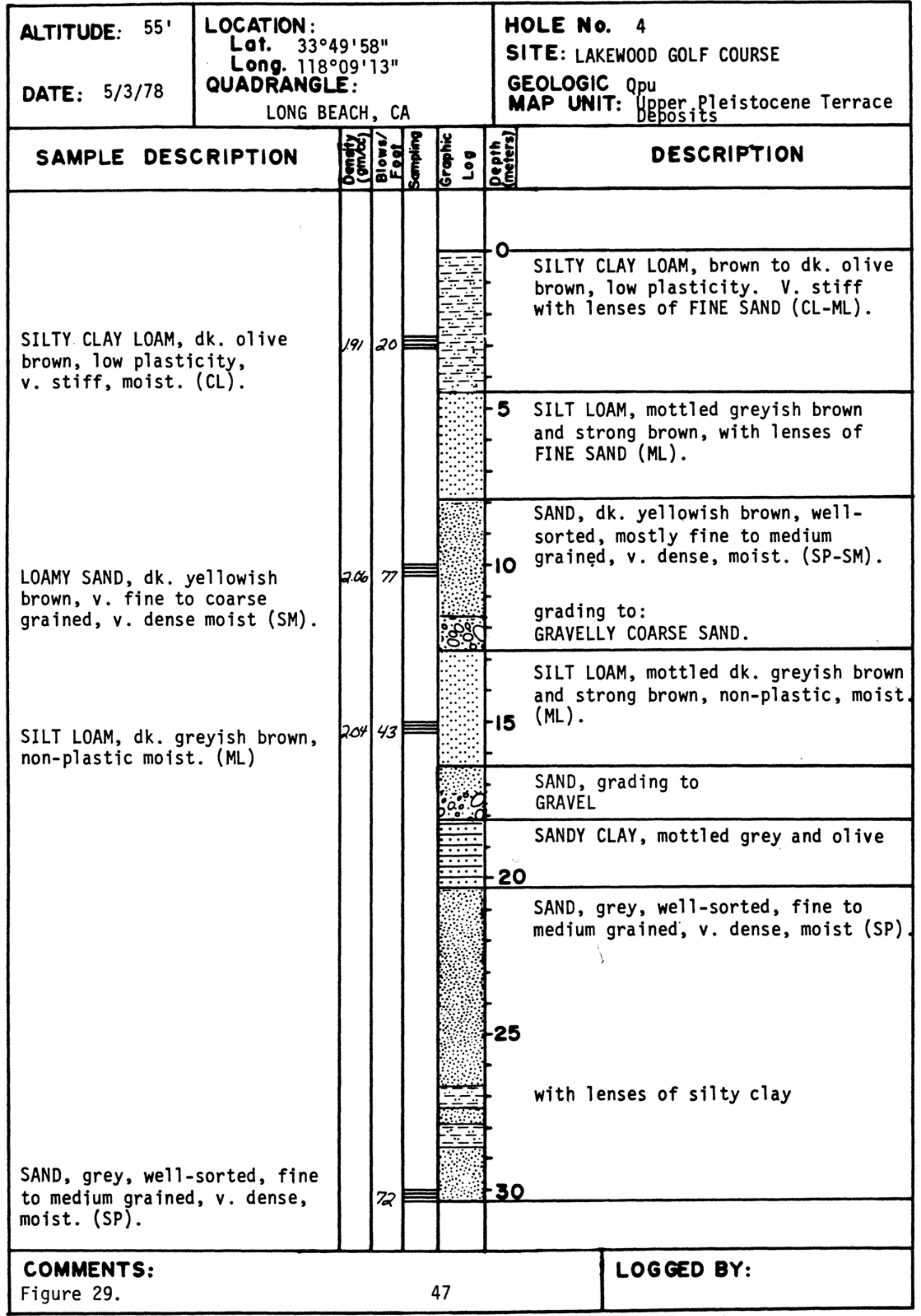




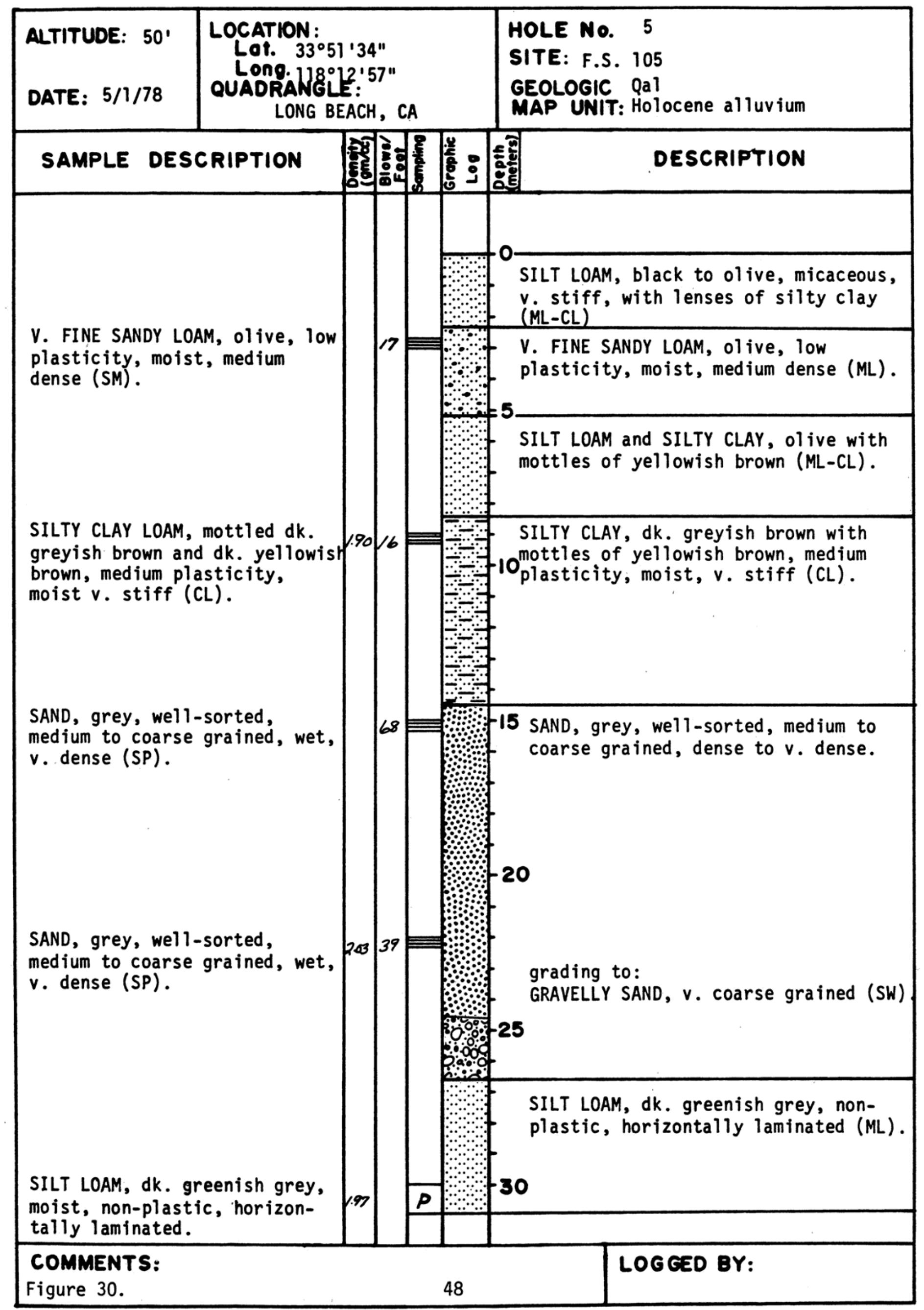




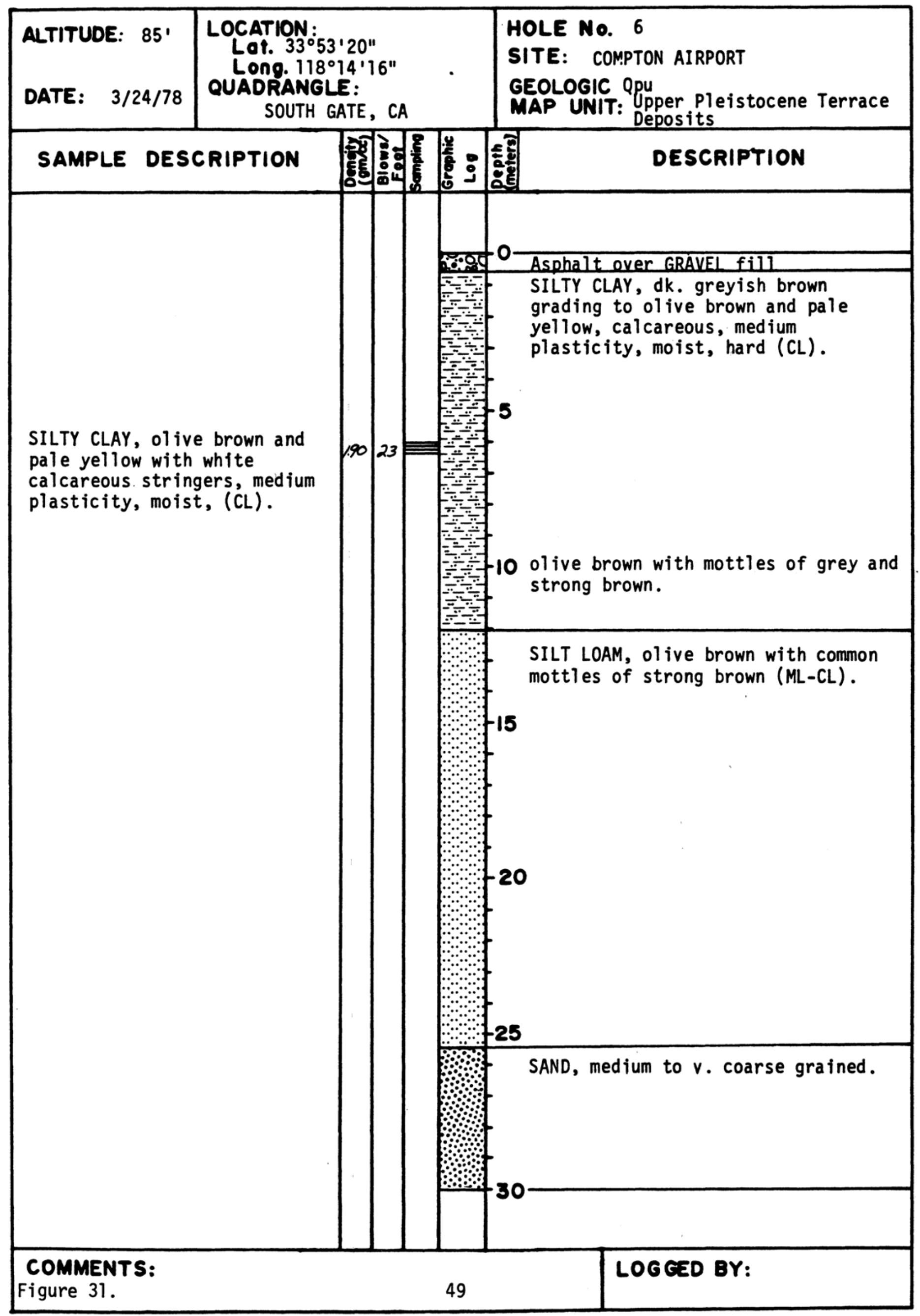




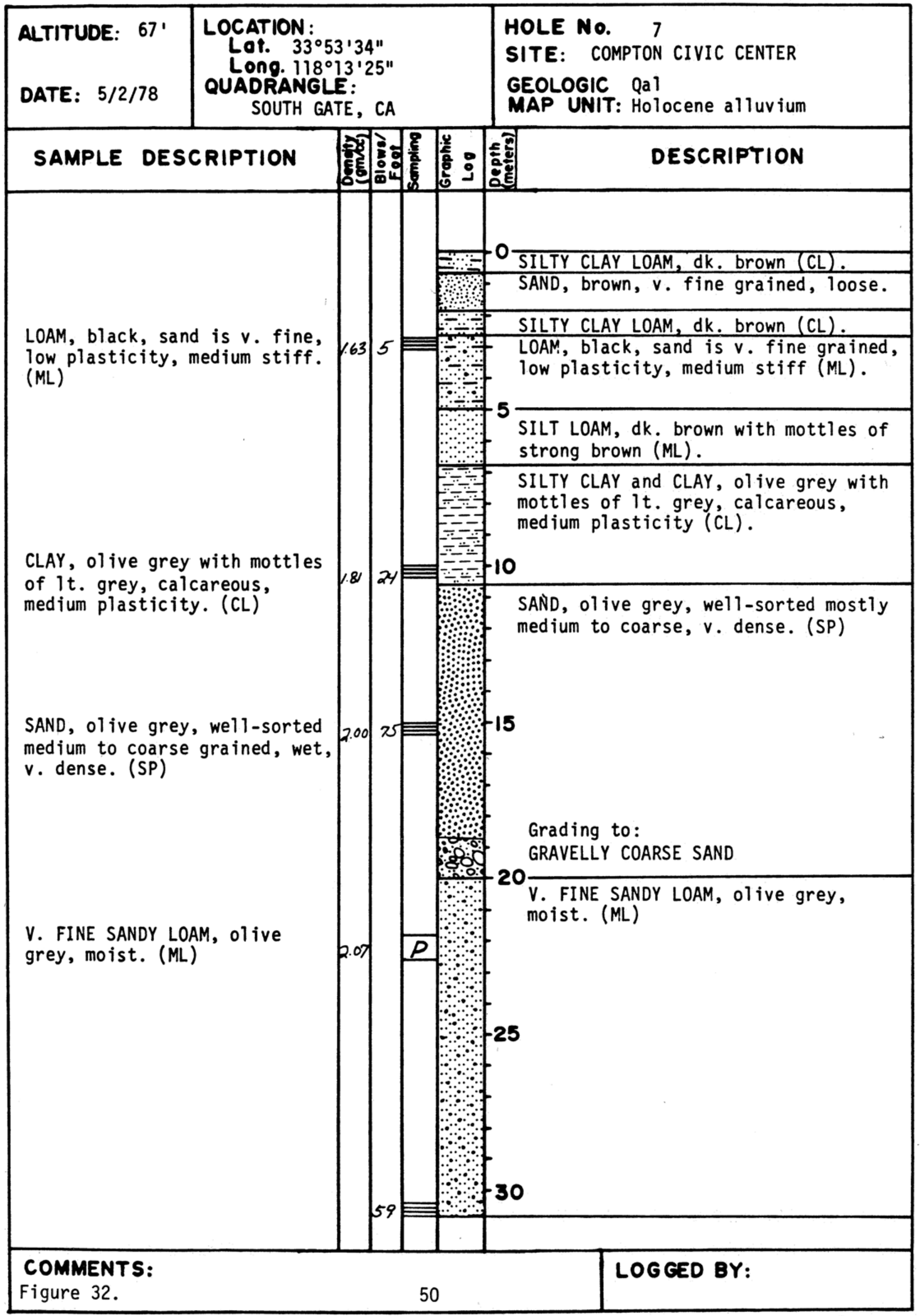




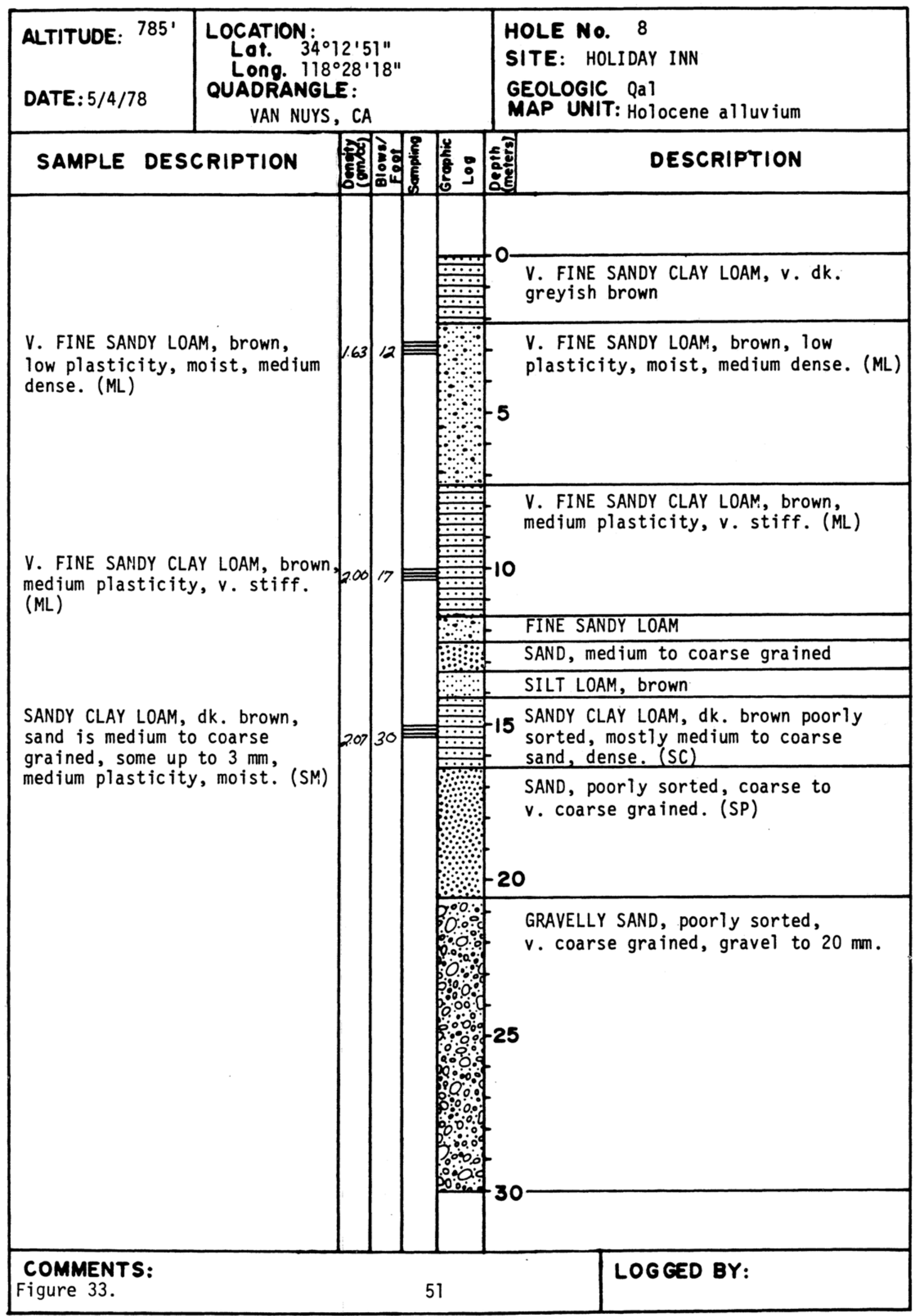




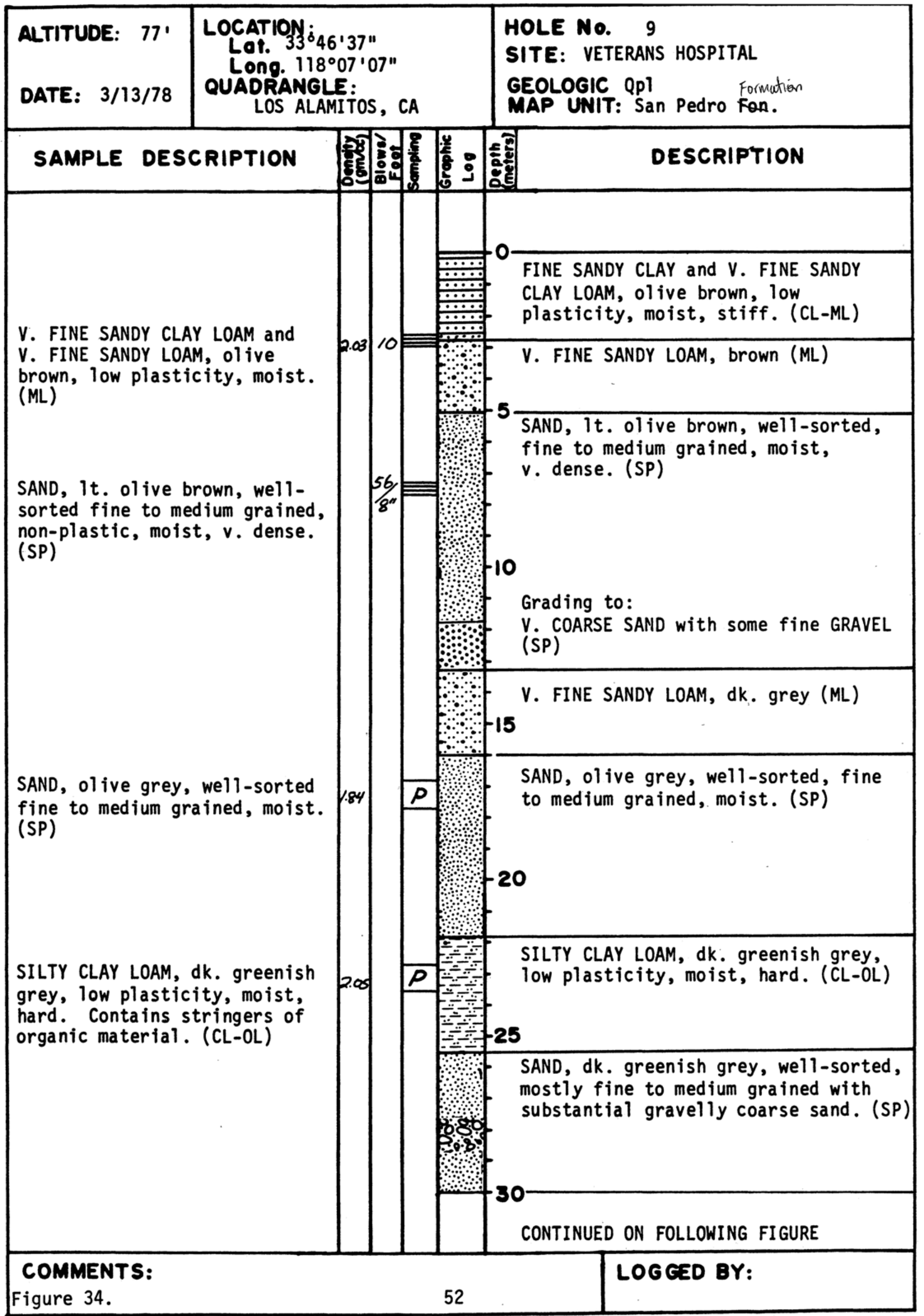




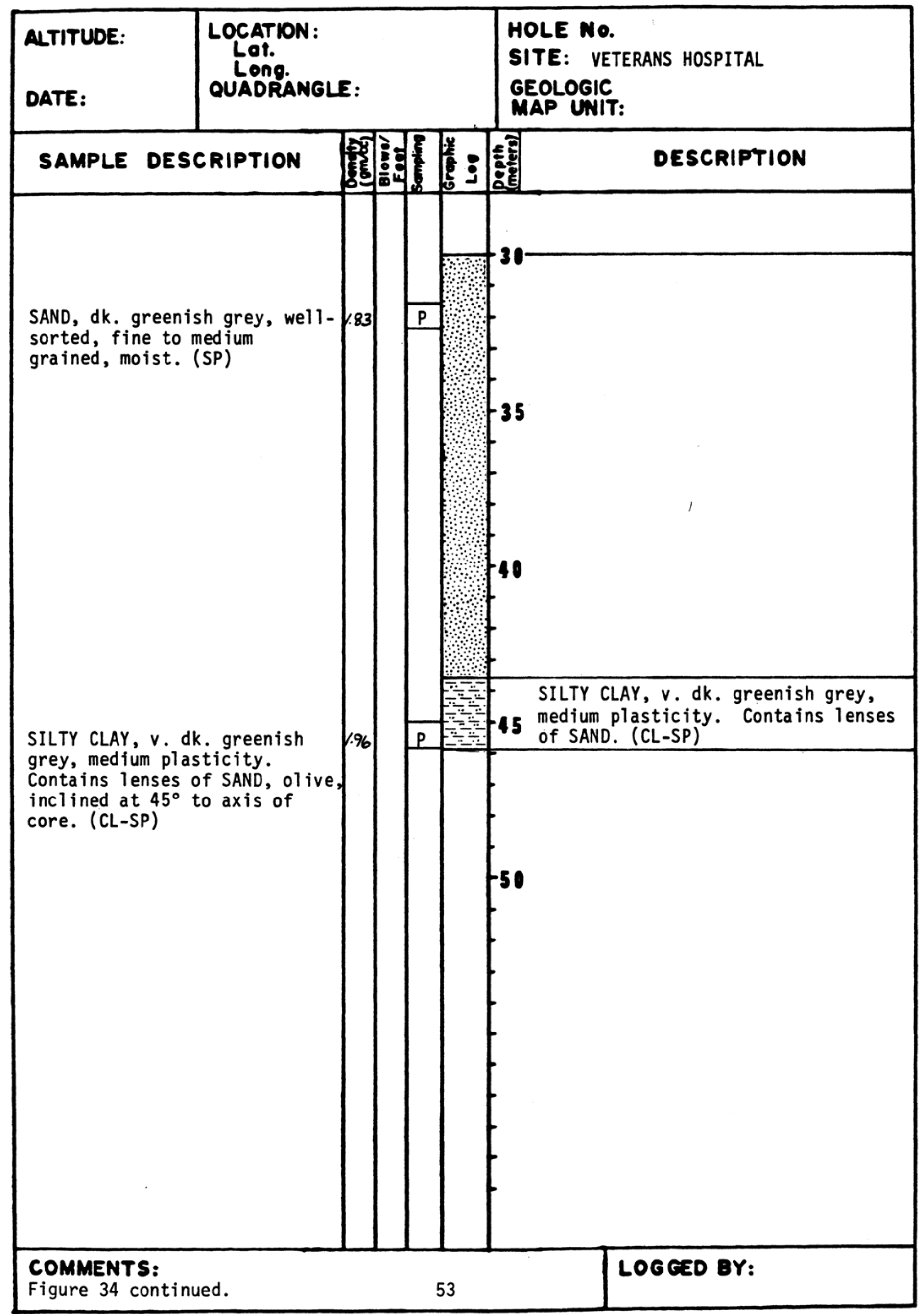




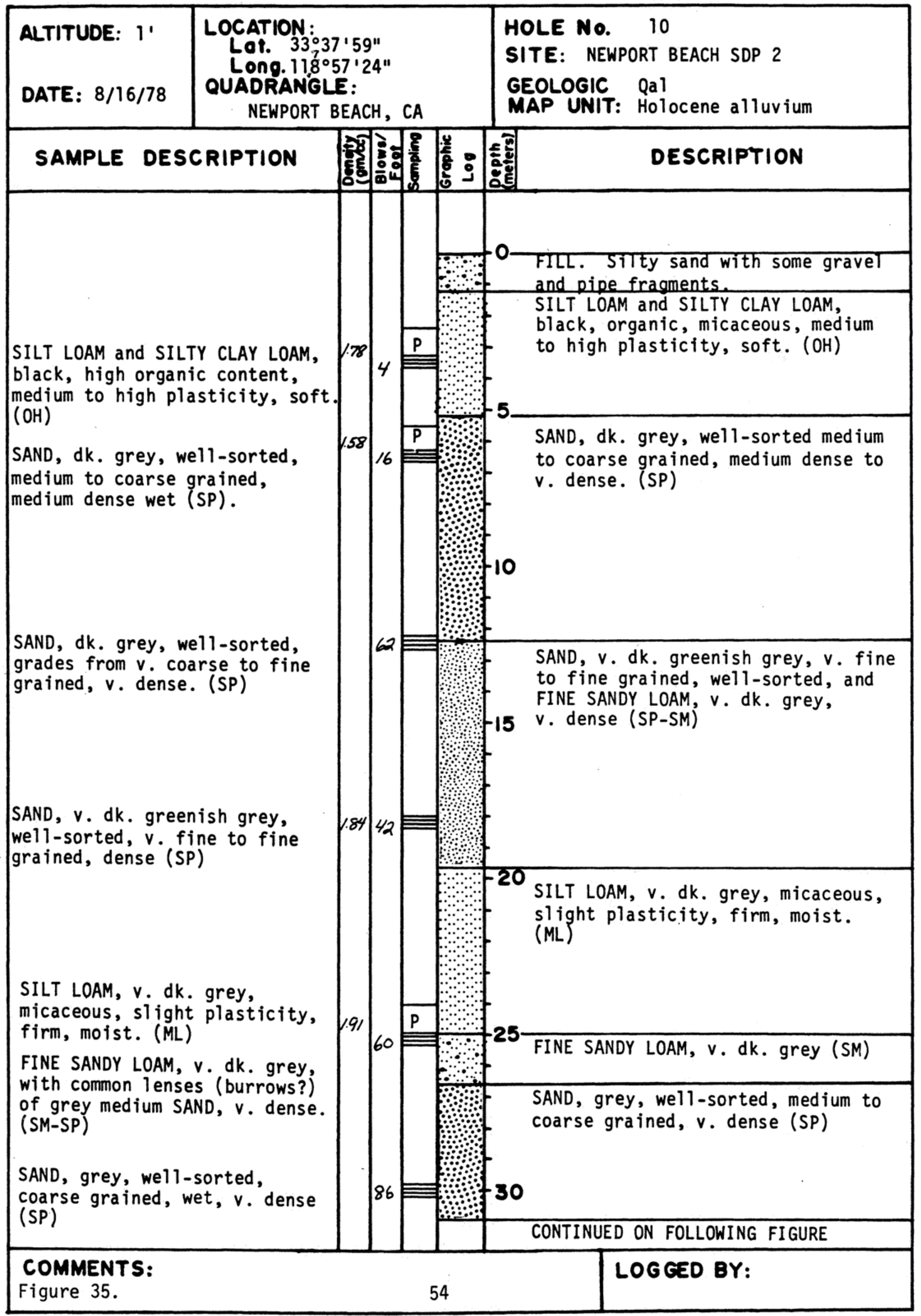




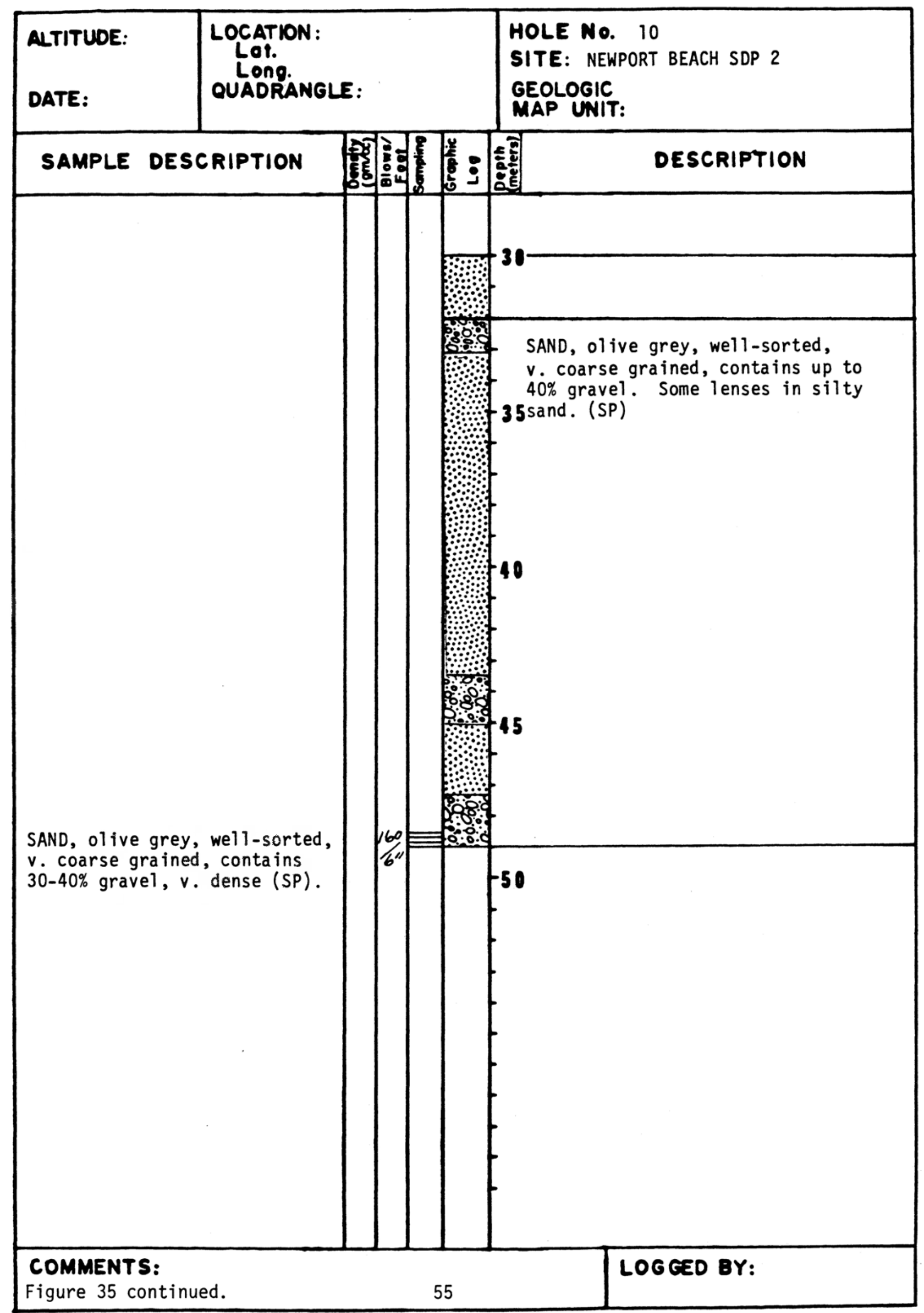




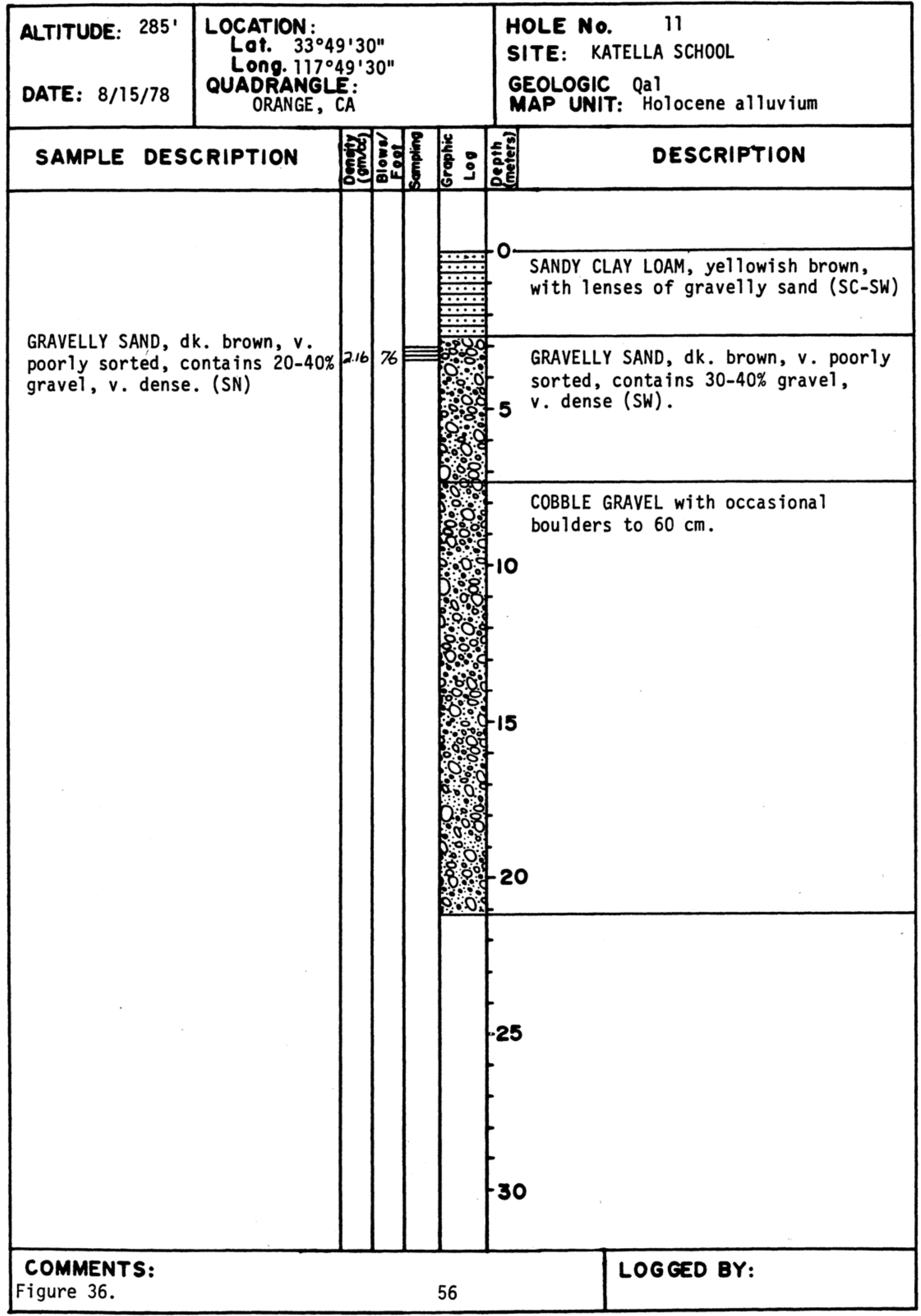




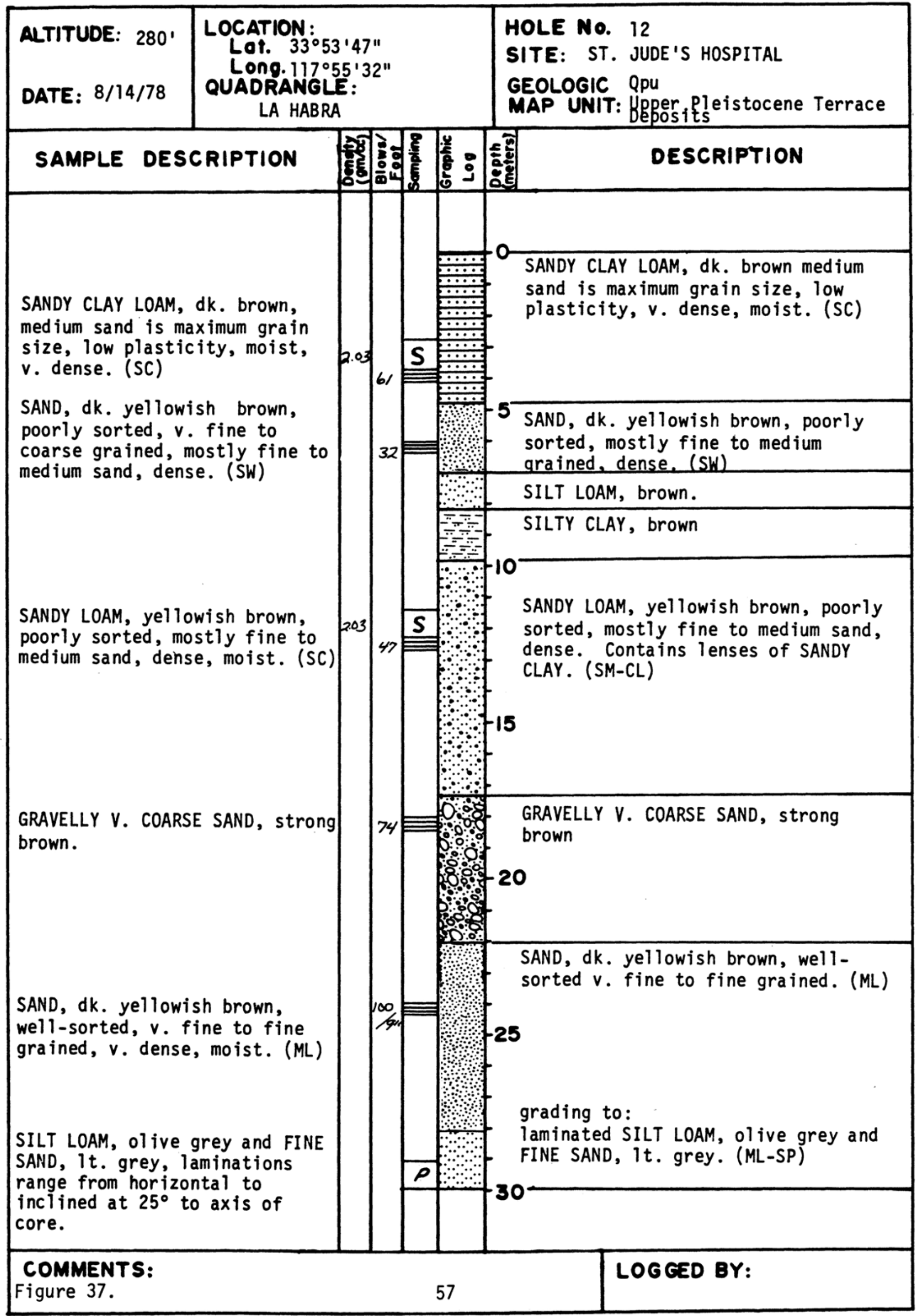




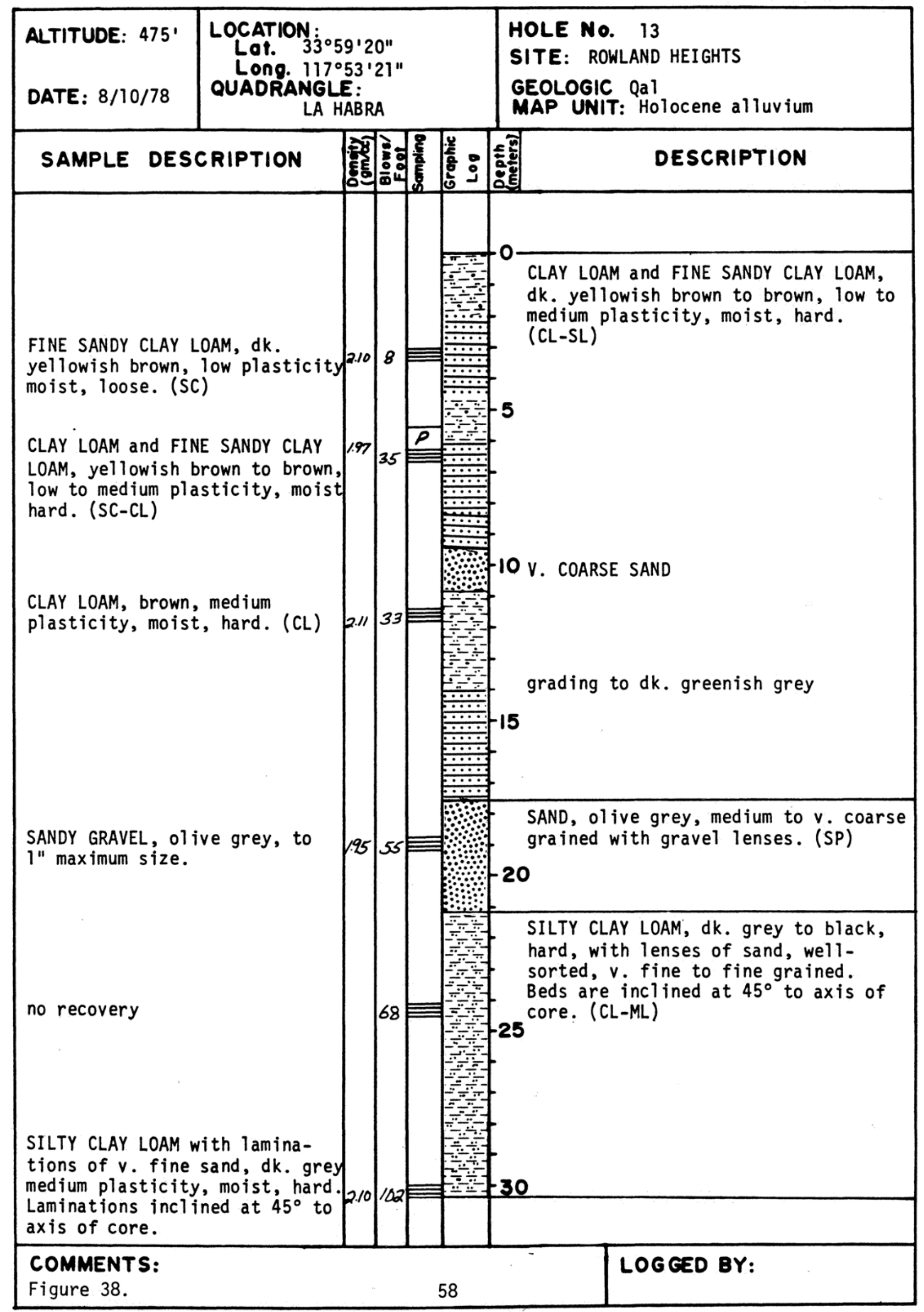




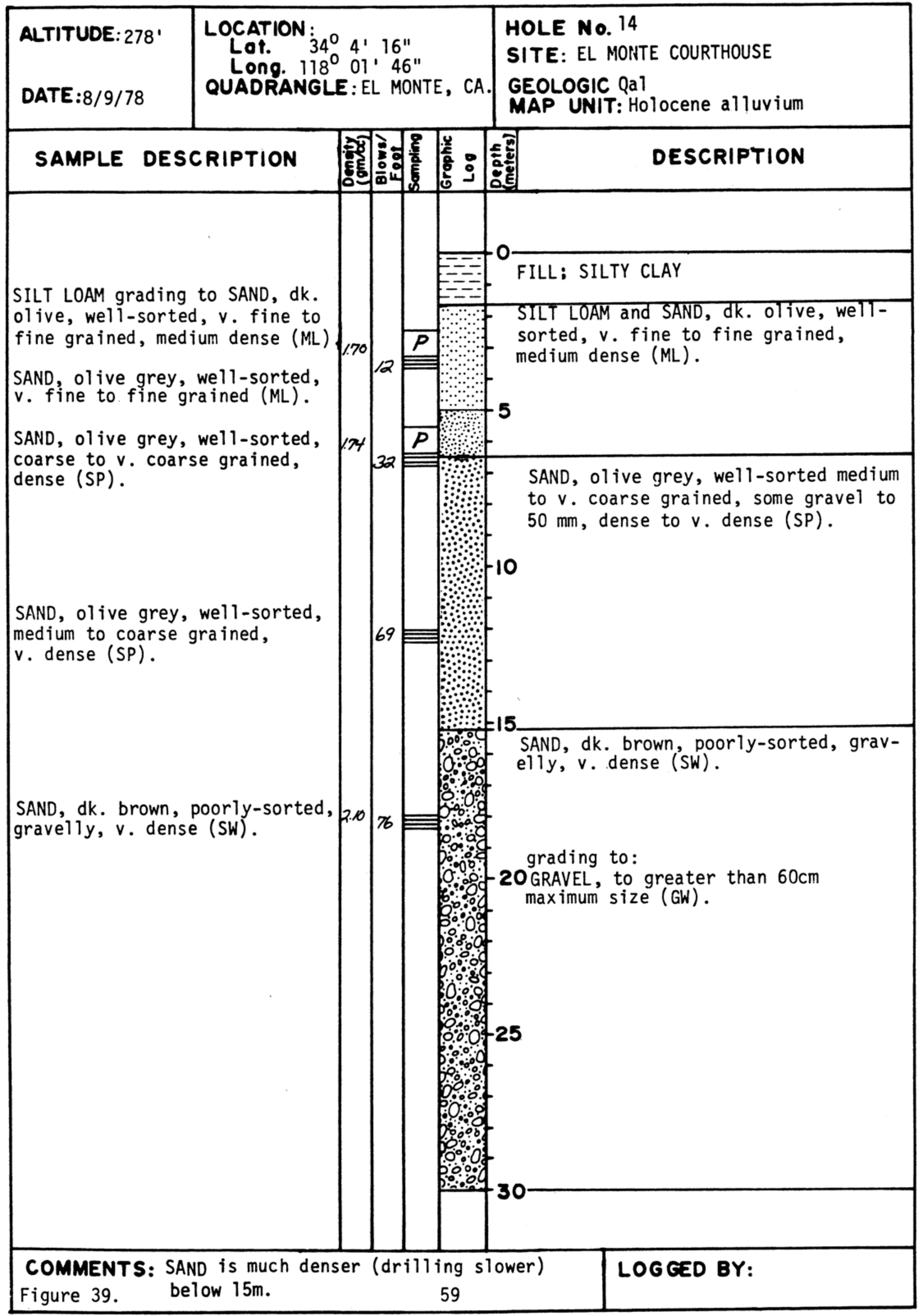




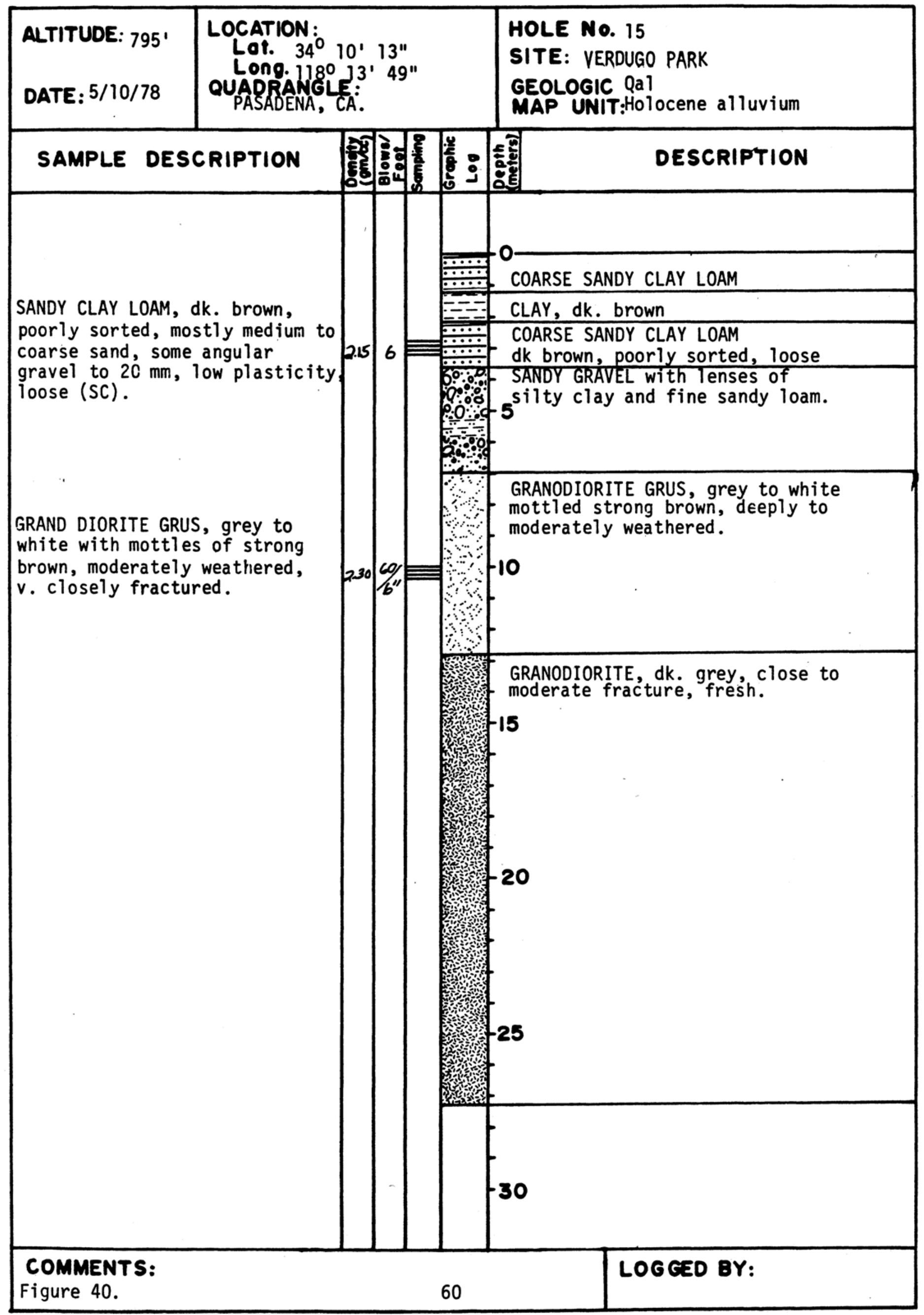




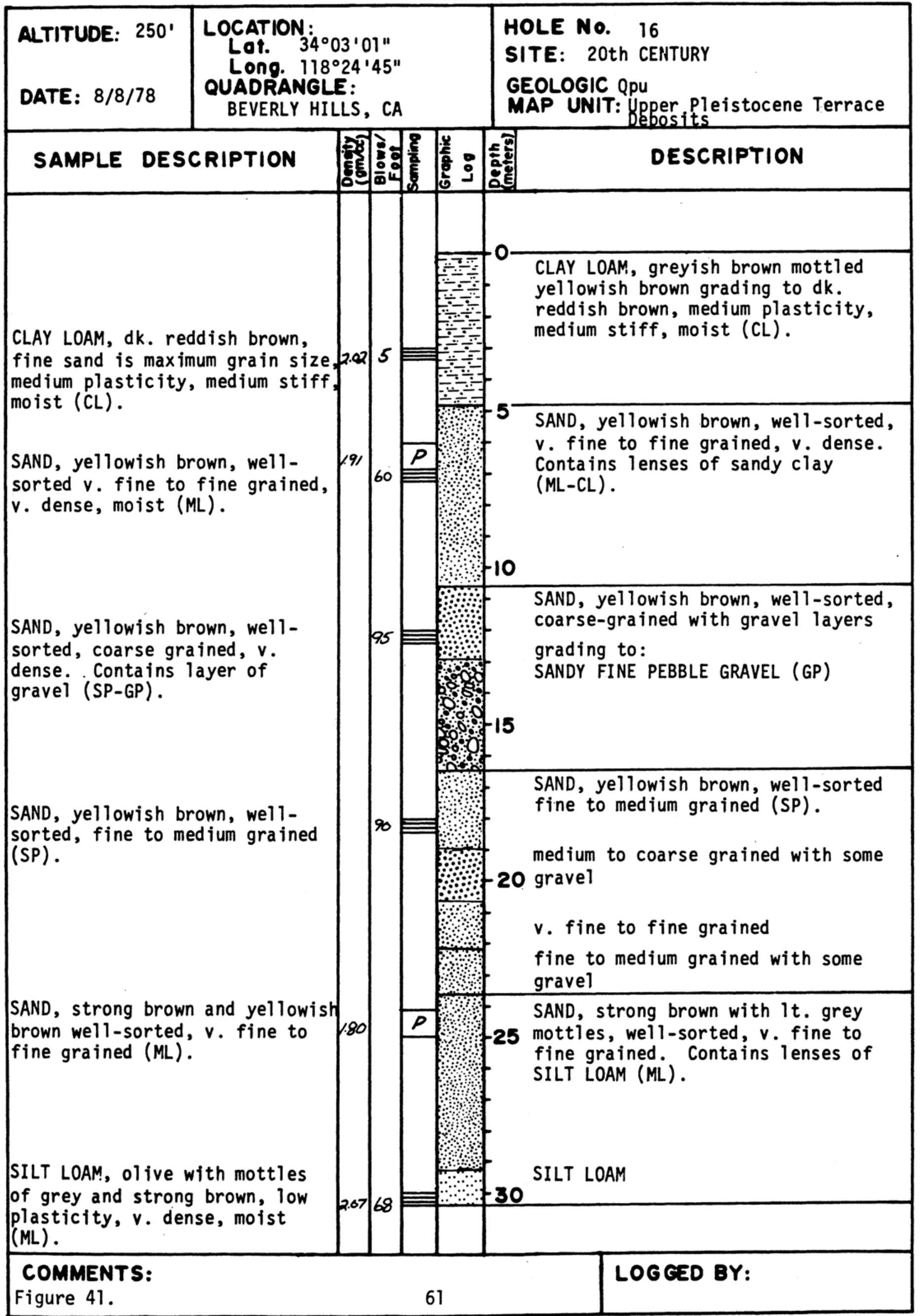




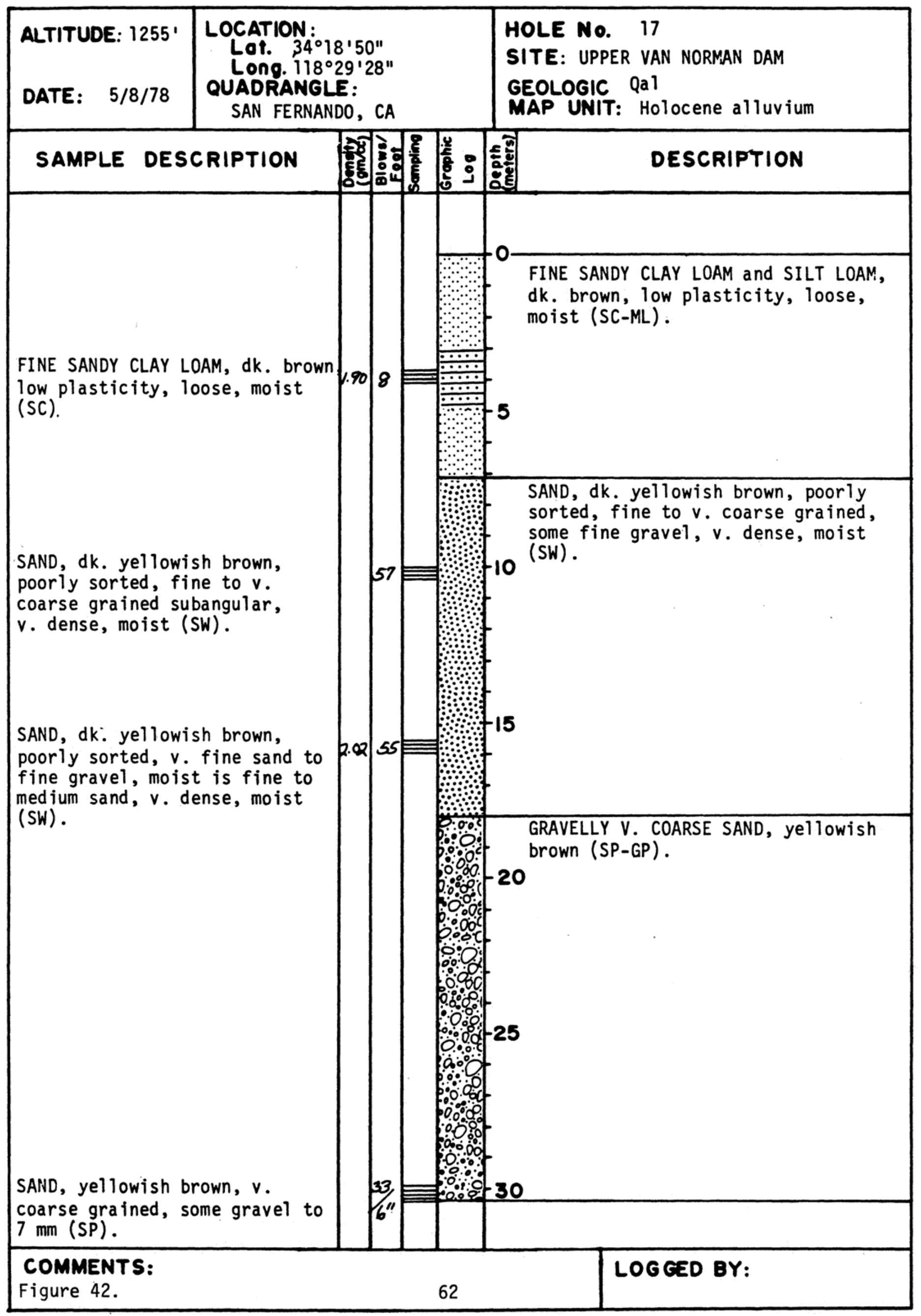




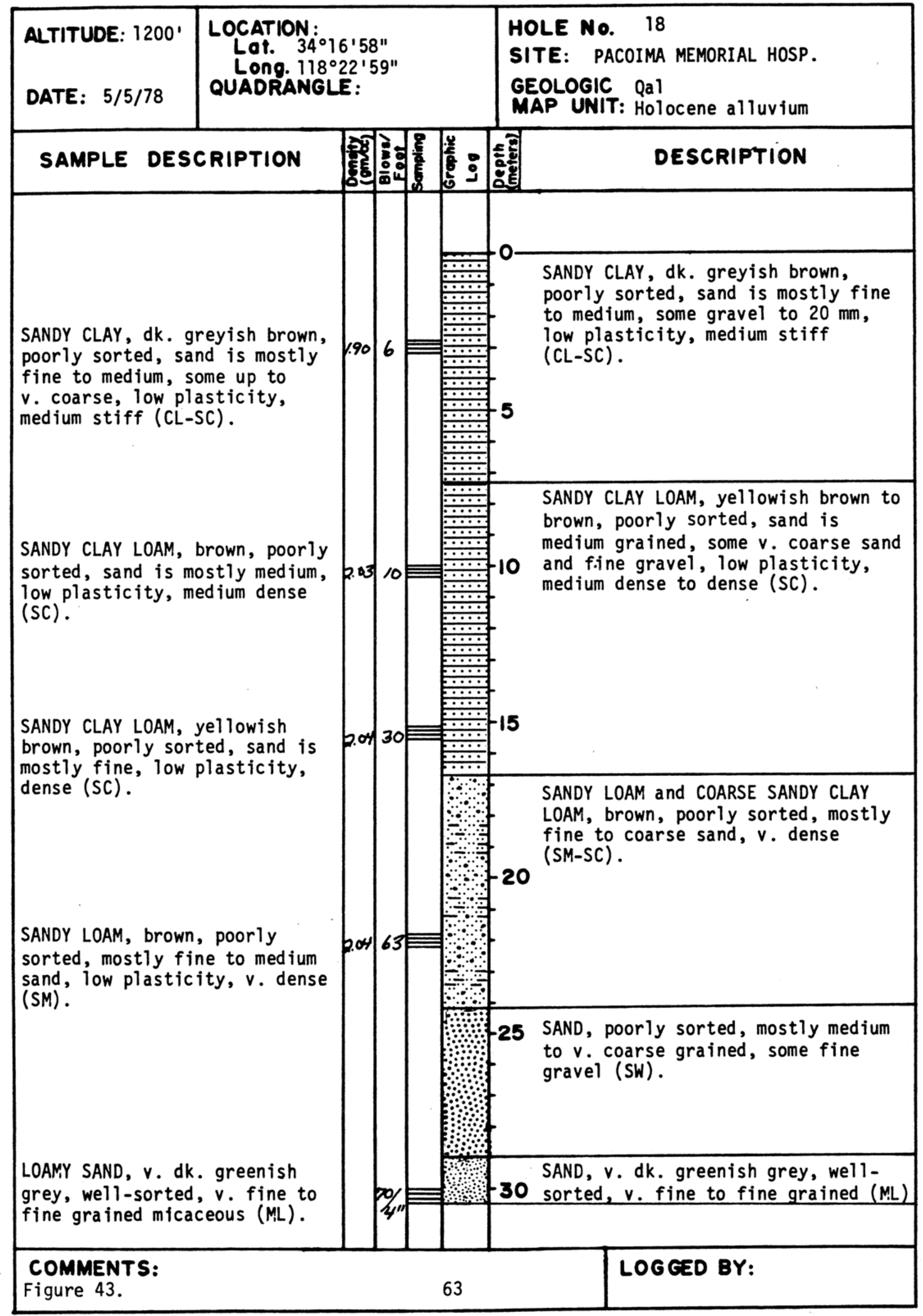




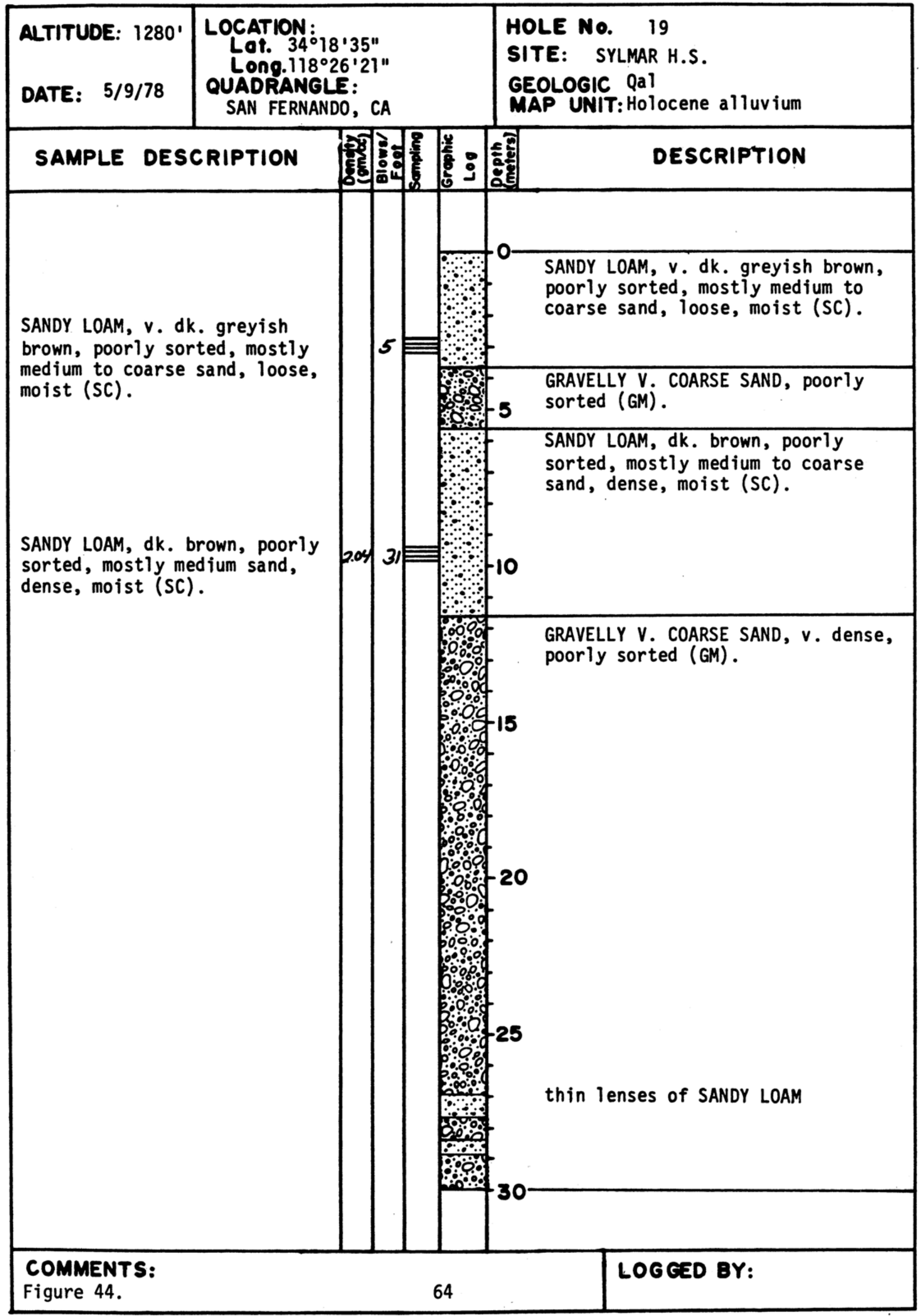




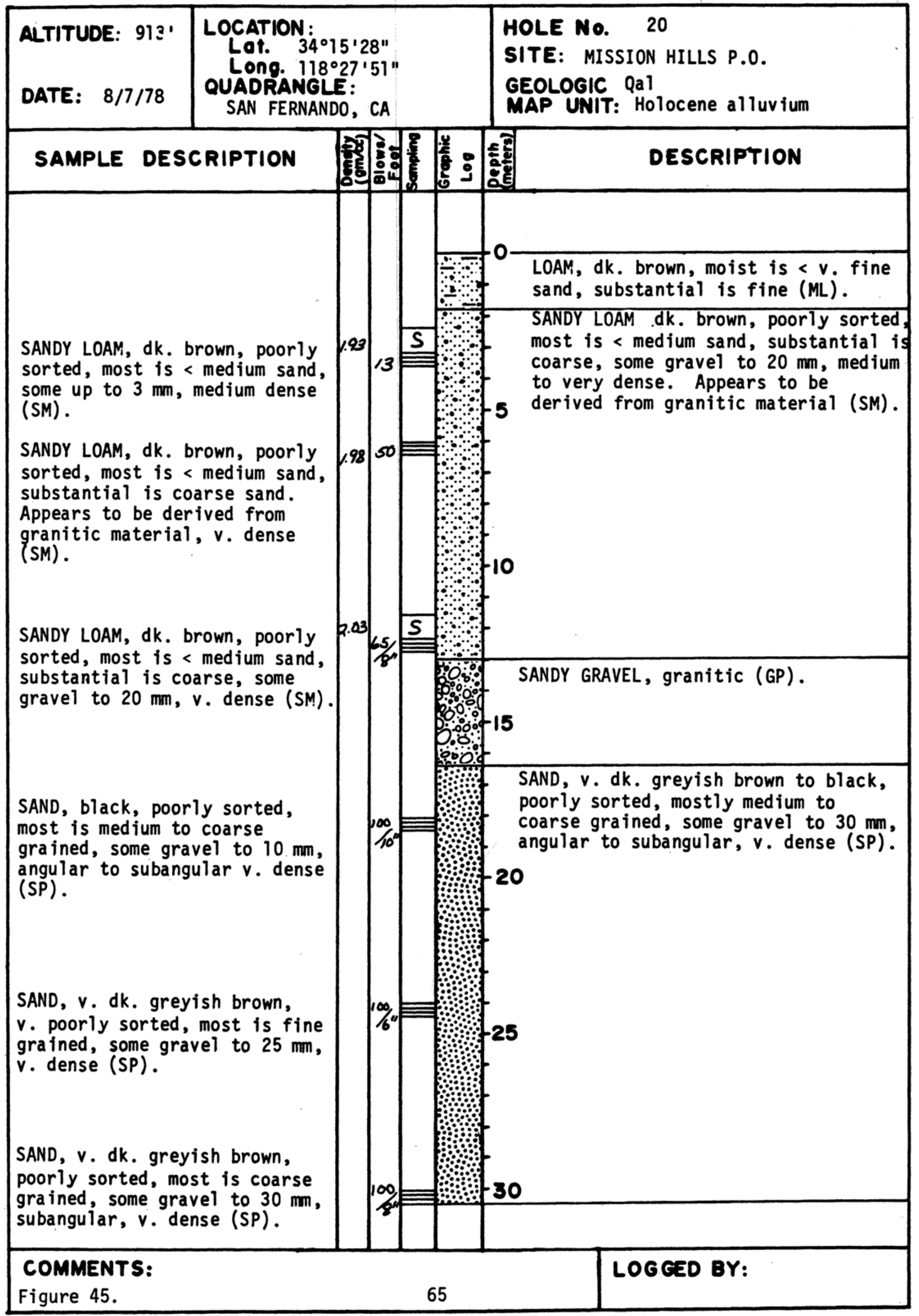




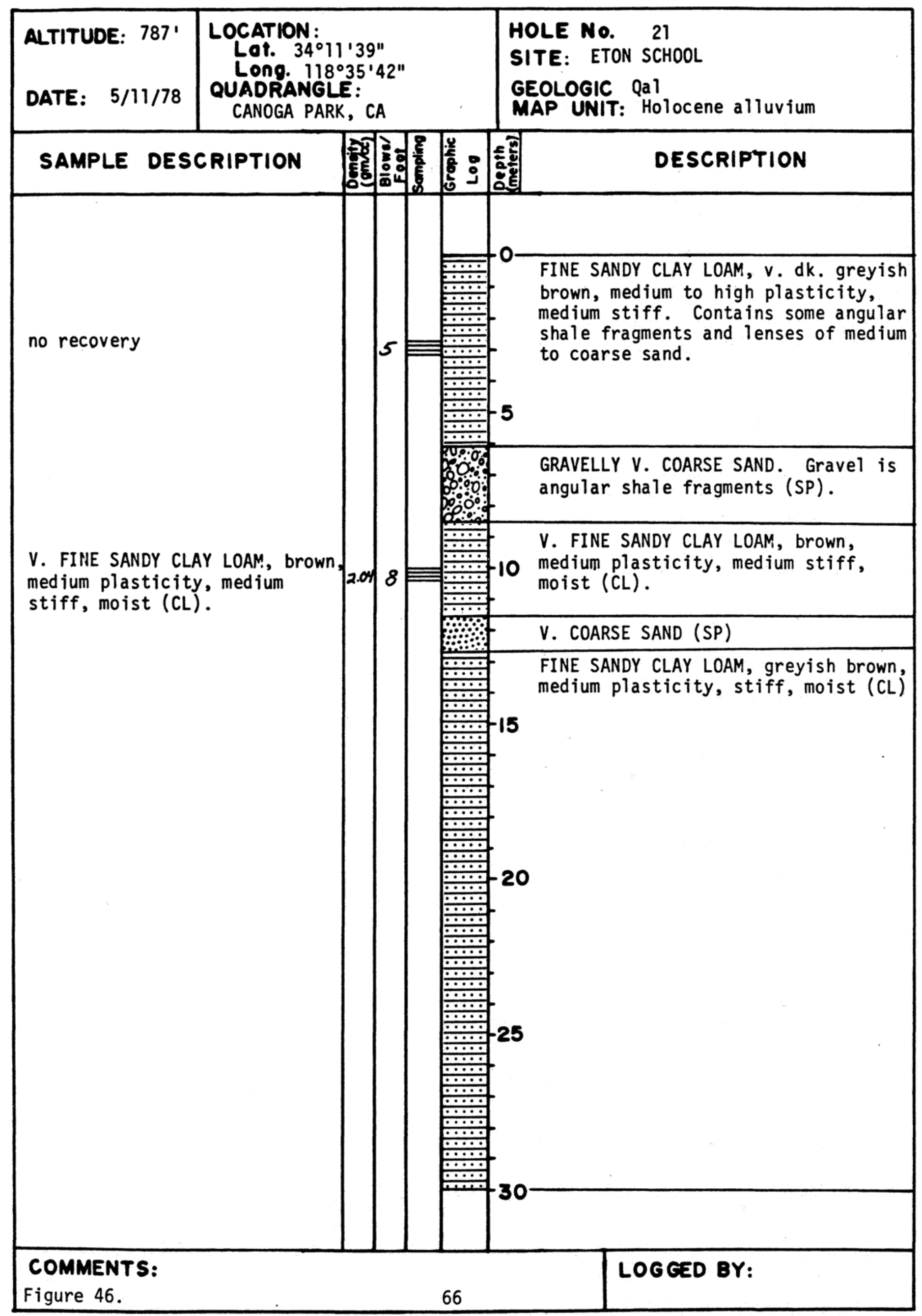


ALTITUDE: $77^{\prime}$ LOCATION:

Lot. $34^{\circ} 11^{\prime} 06^{\prime \prime}$

Long. $119^{\circ} \mathrm{C} 2^{\prime} 08^{\prime \prime}$

DATE: $8 / 2 / 78$
QUADRANGLE:

CAMARILLO, CA
HOLE NO. 22

SITE: CAMARILLO STATE HOSP.

GEOLOGIC Qd

MAP UNIT: Holocene deltaic deposits

\section{SAMPLE DESCRIPTION}

SAND, yellowish brown, mostly fine to coarse grained, some gravel to $8 \mathrm{~mm}$, medium dense, moist (SW).

V. FINE SANDY LOAM, brown, low plasticity, dense, moist (ML).

SANDY LOAM, yellowish brown, mostly $v$. fine to fine sand, low plasticity, dense, moist (ML).

LOAM, black, sand is $v$. fine grained, low plasticity, moist (ML).
SILTY CLAY, black, medium plasticity, wet, hard (CL).

\section{DESCRIPTION}

SAND, yellowish brown, mostly fine to coarse grained, some gravel to $8 \mathrm{~mm}$, medium dense, moist (SW).

SANDY LOAM, yellowish brown to brown, mostly $v$. fine to fine sand, dense, moist. Contains lenses of SILTY CLAY and SILT LOAM (ML-CL).
SILTY CLAY and V. FINE SAND LOAM, black, low to medium plasticity, wet, hard. Contains lenses of wellsorted medium to coarse SAND $(M L-C L, S P)$.

\section{COMMENTS:}

Figure 47 . 


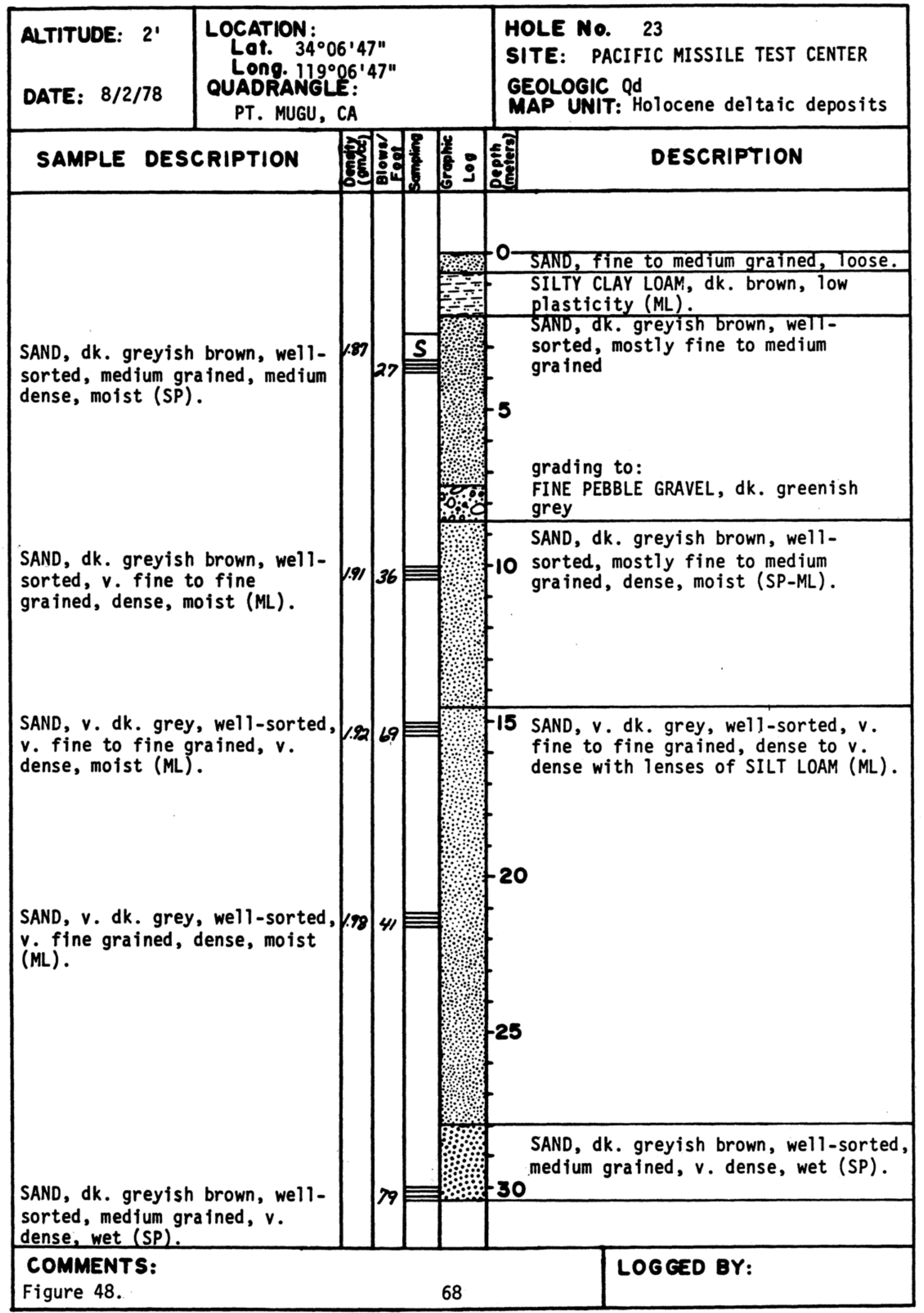




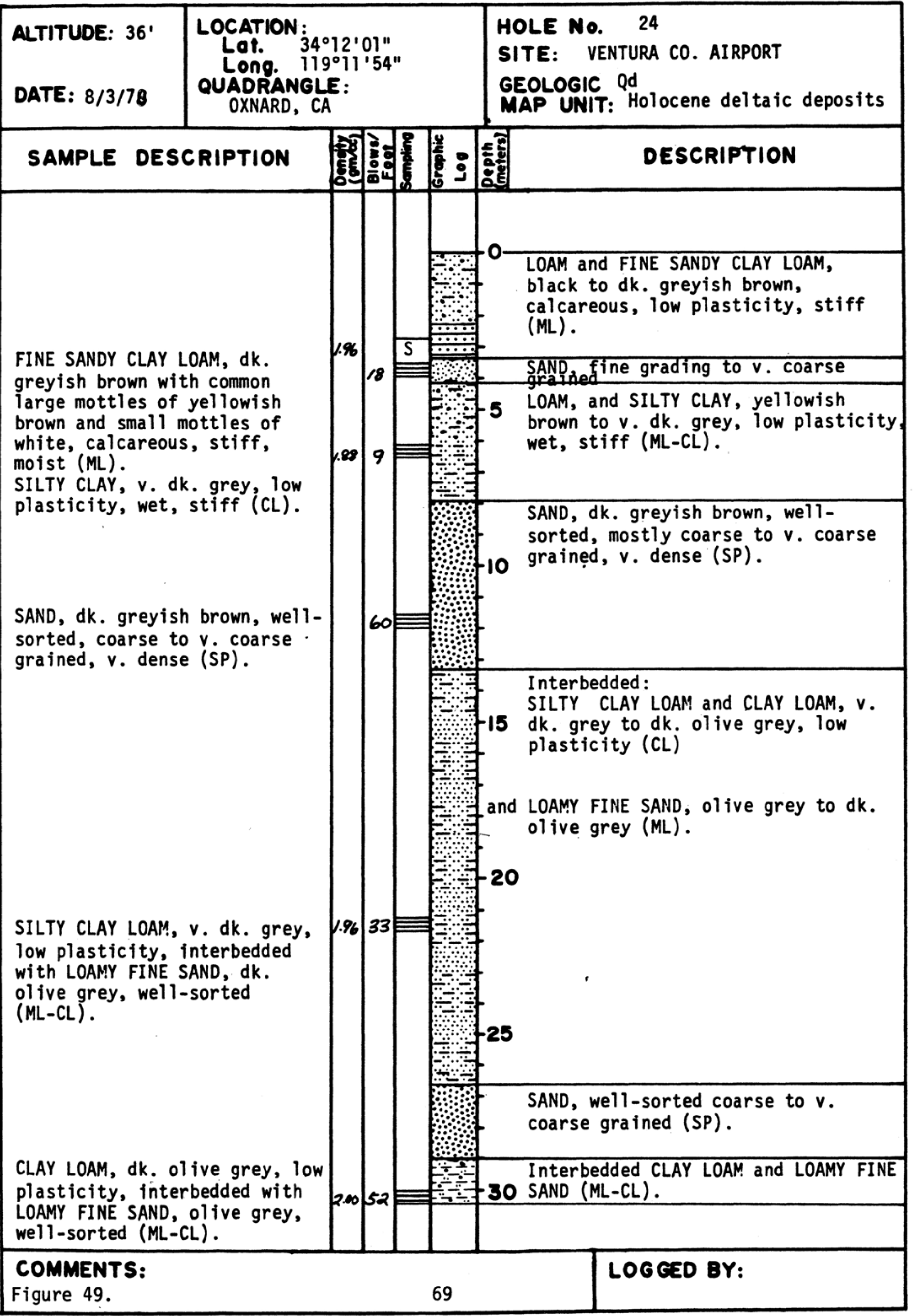




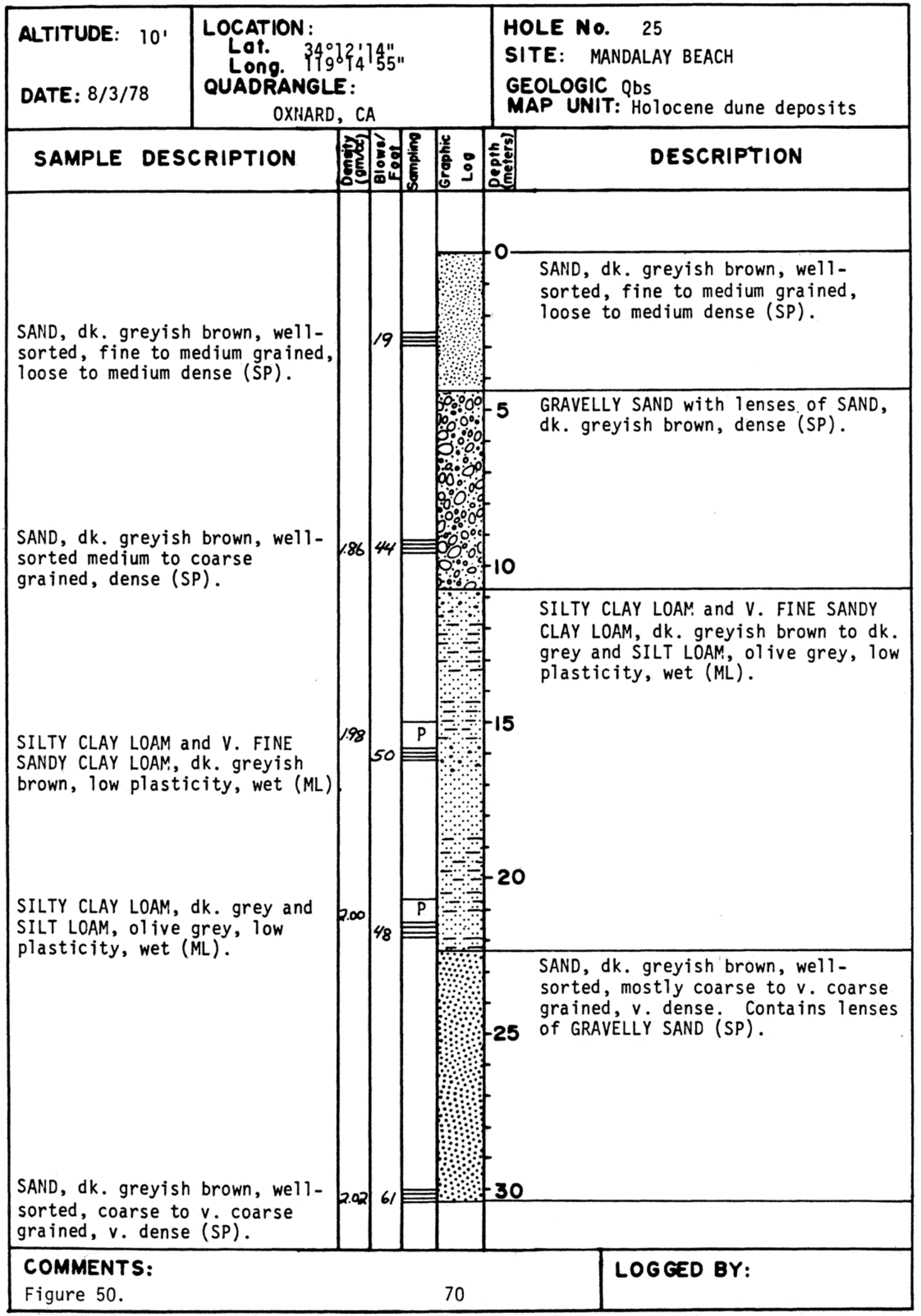




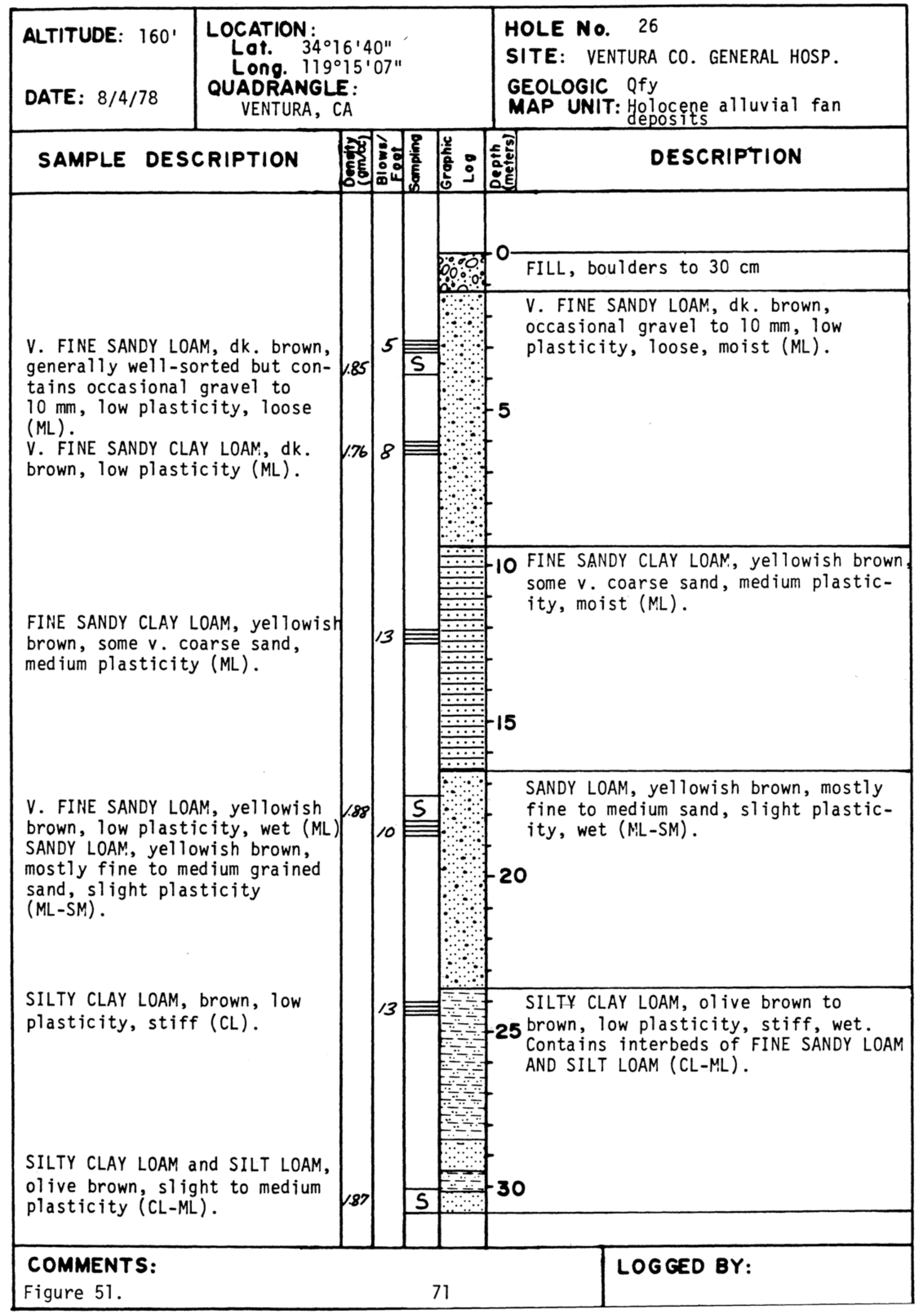




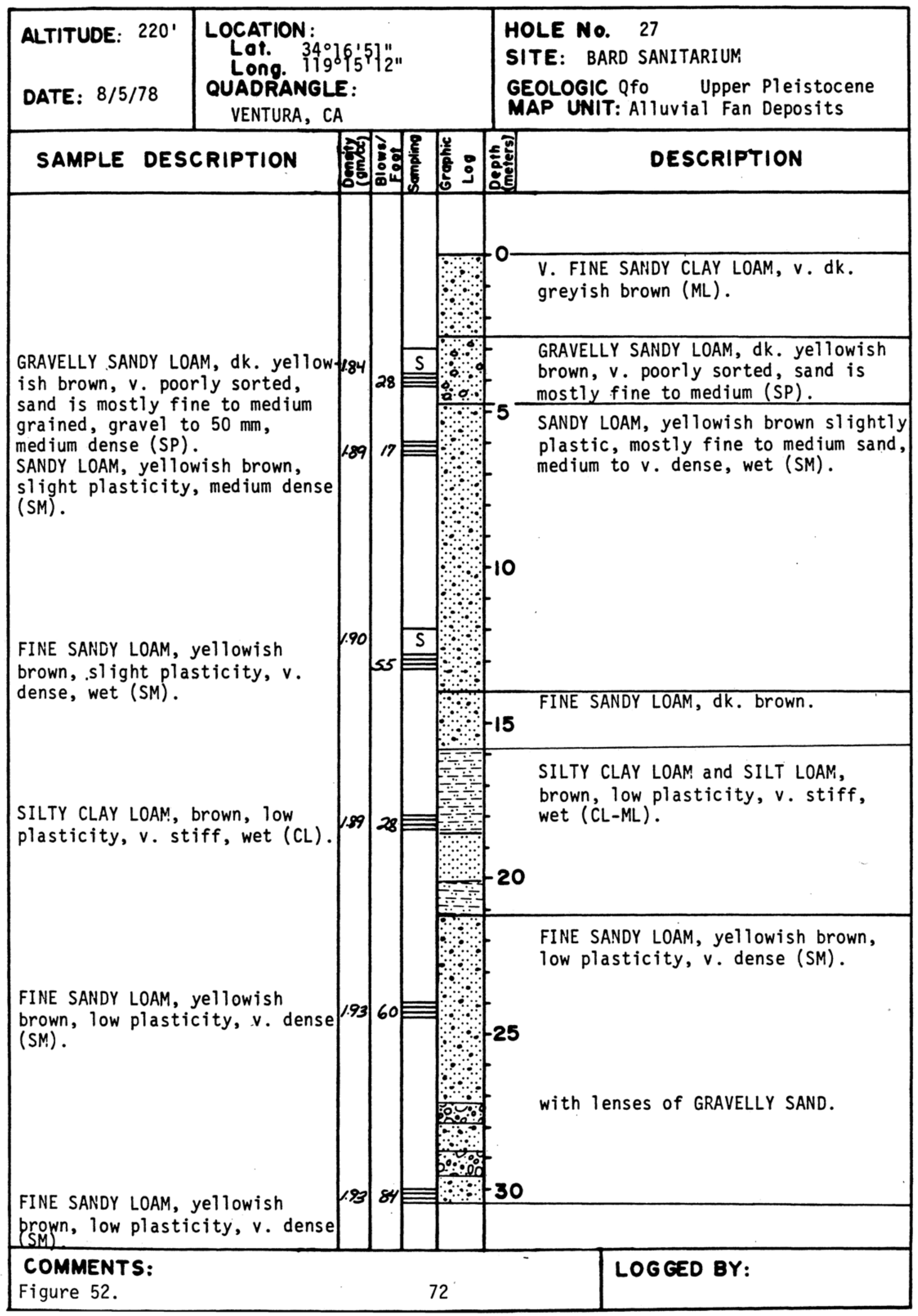




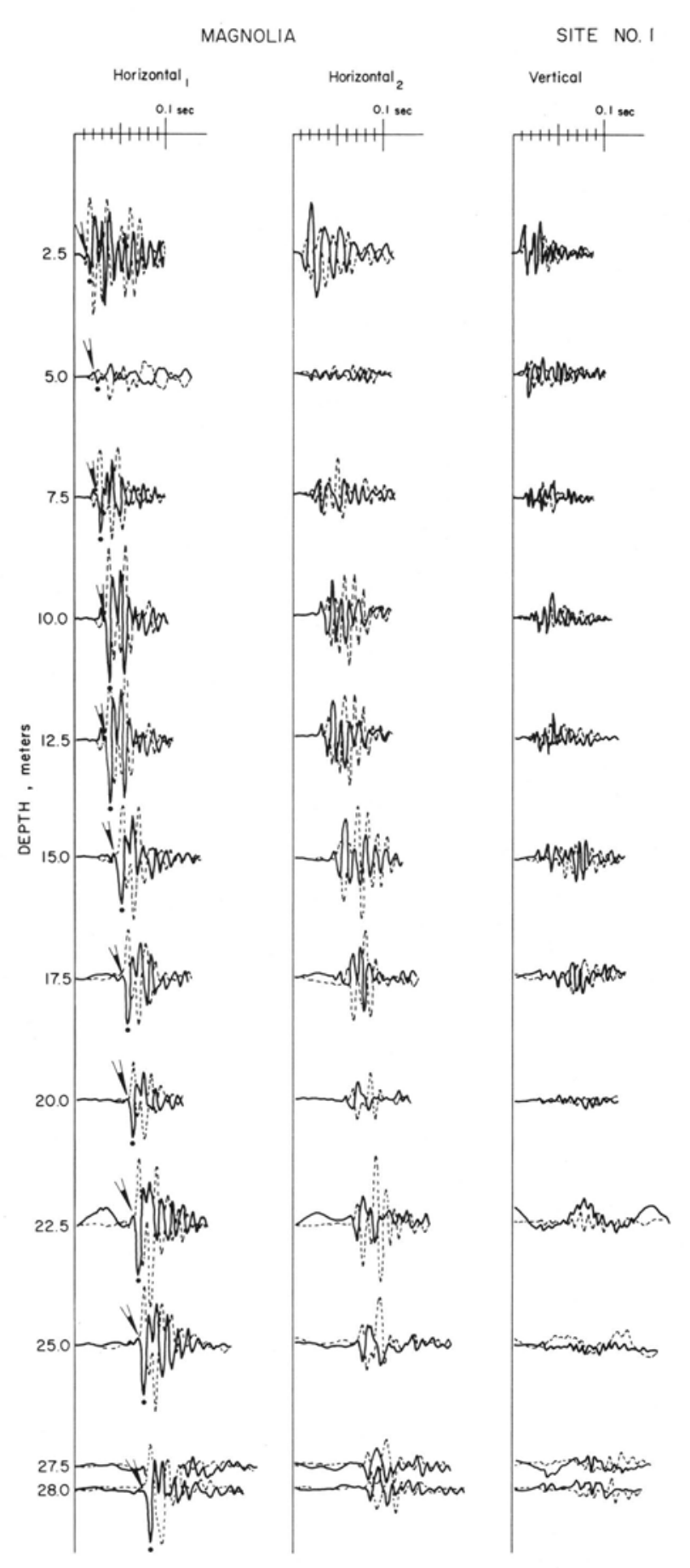

Figure 53.

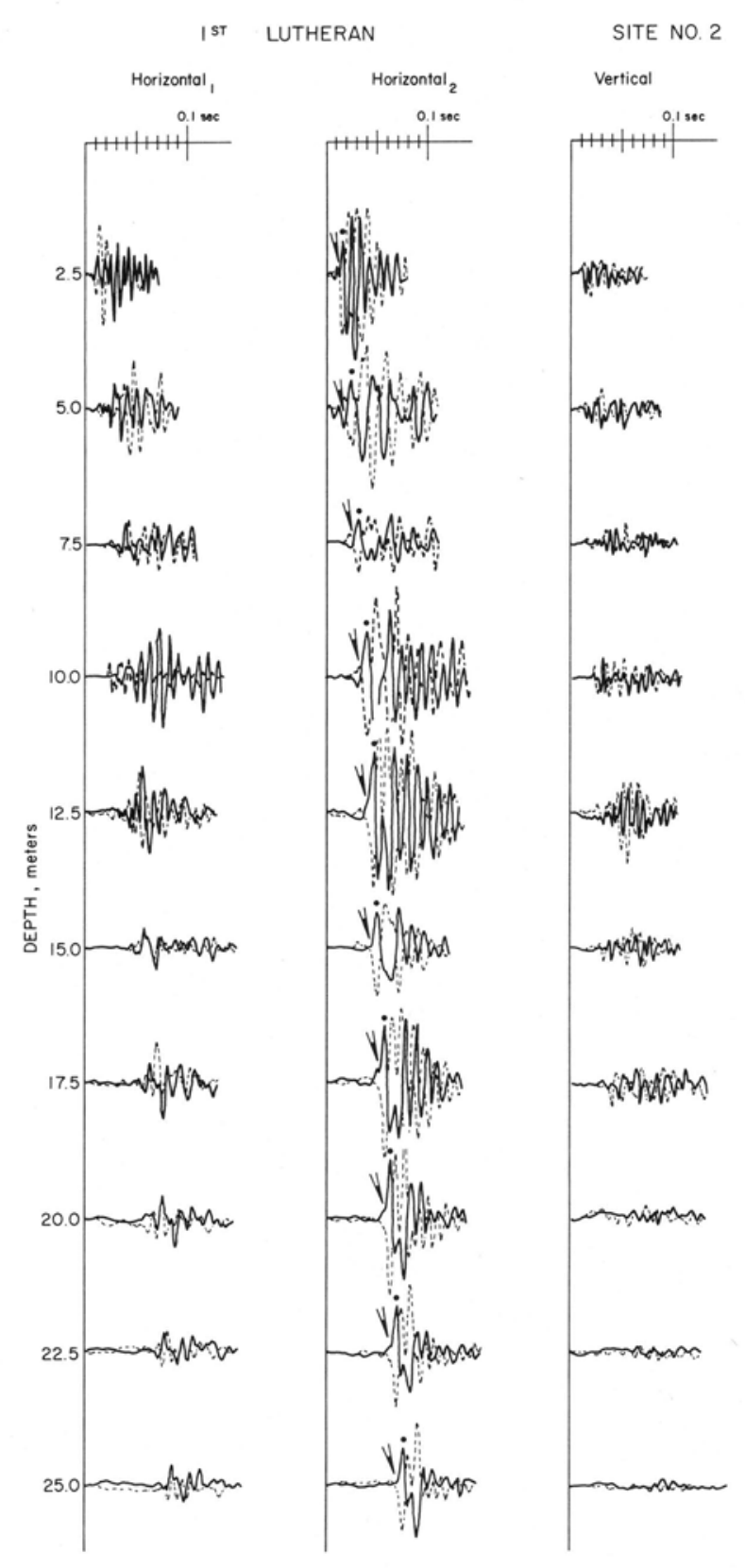

Figure 54. 


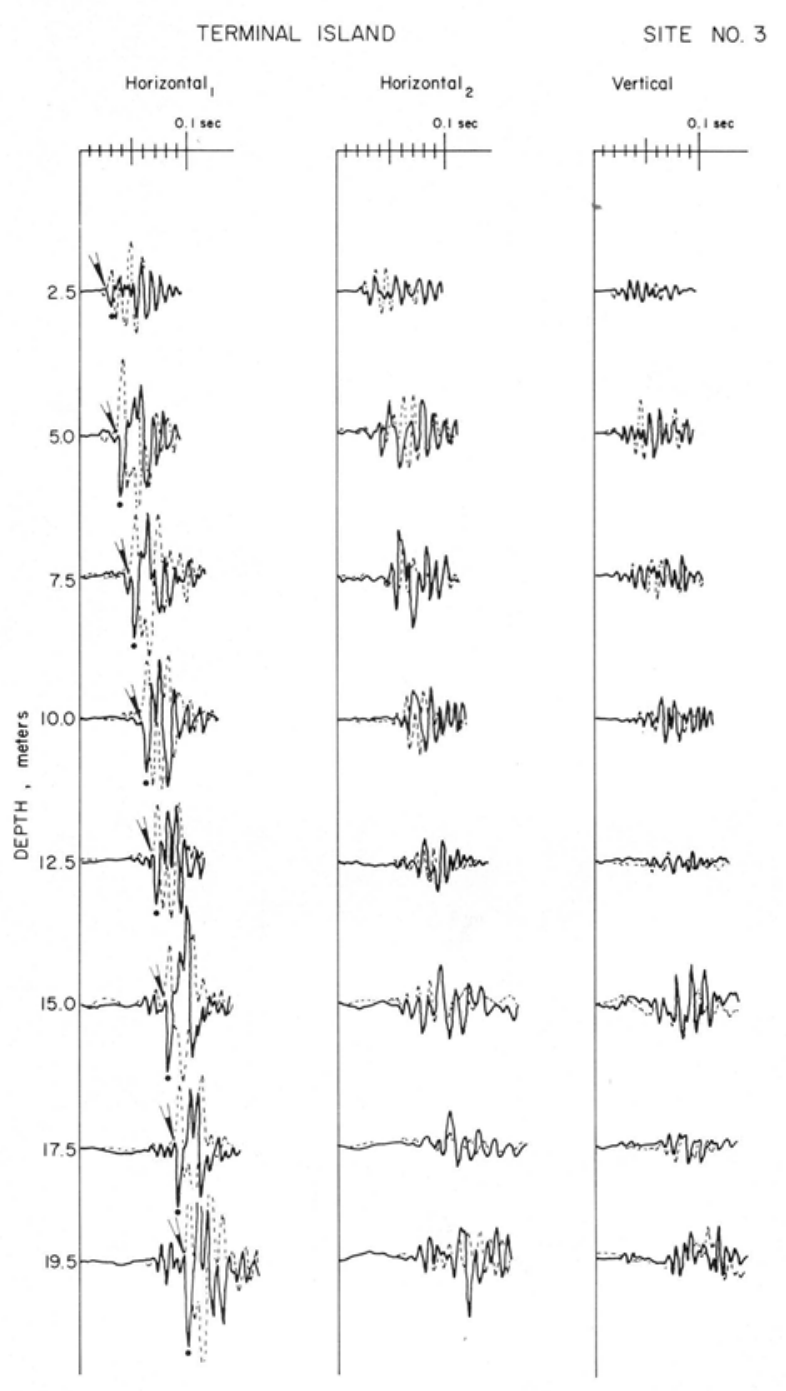

Figure 55.

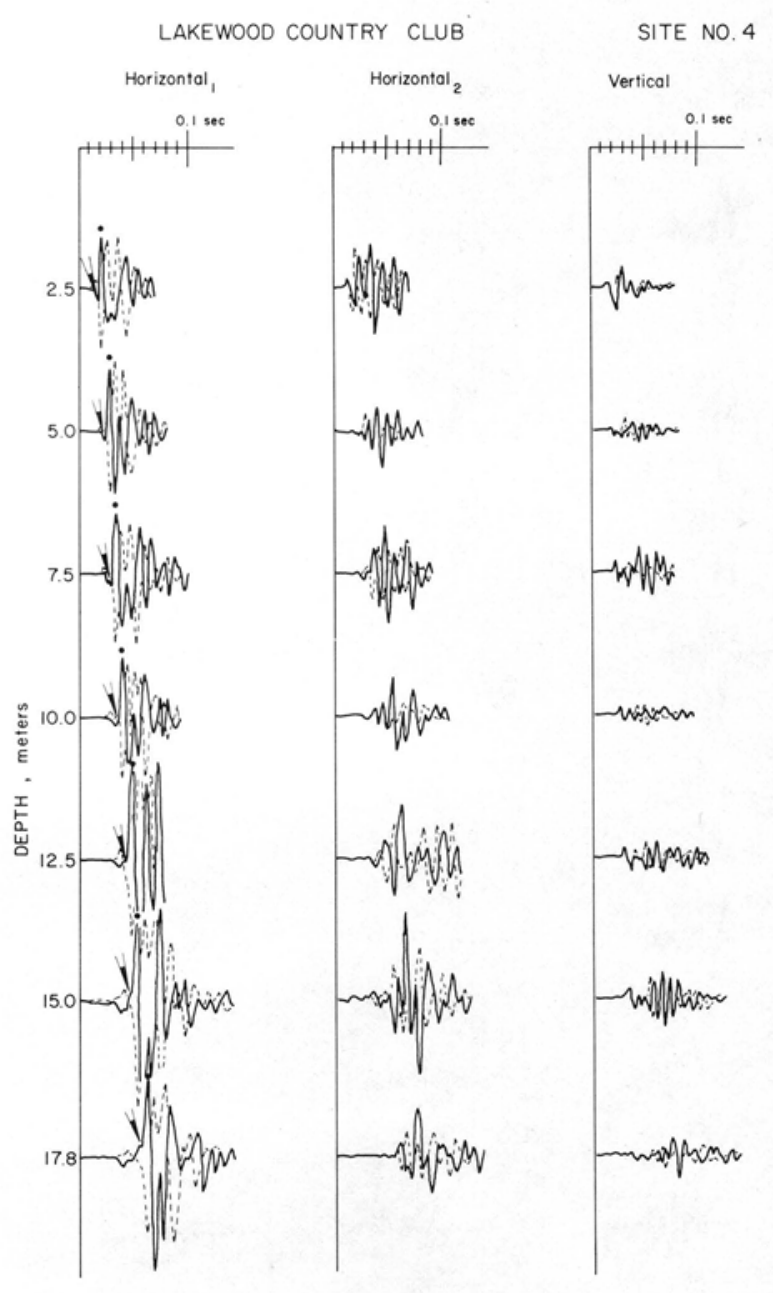

Figure 56. 


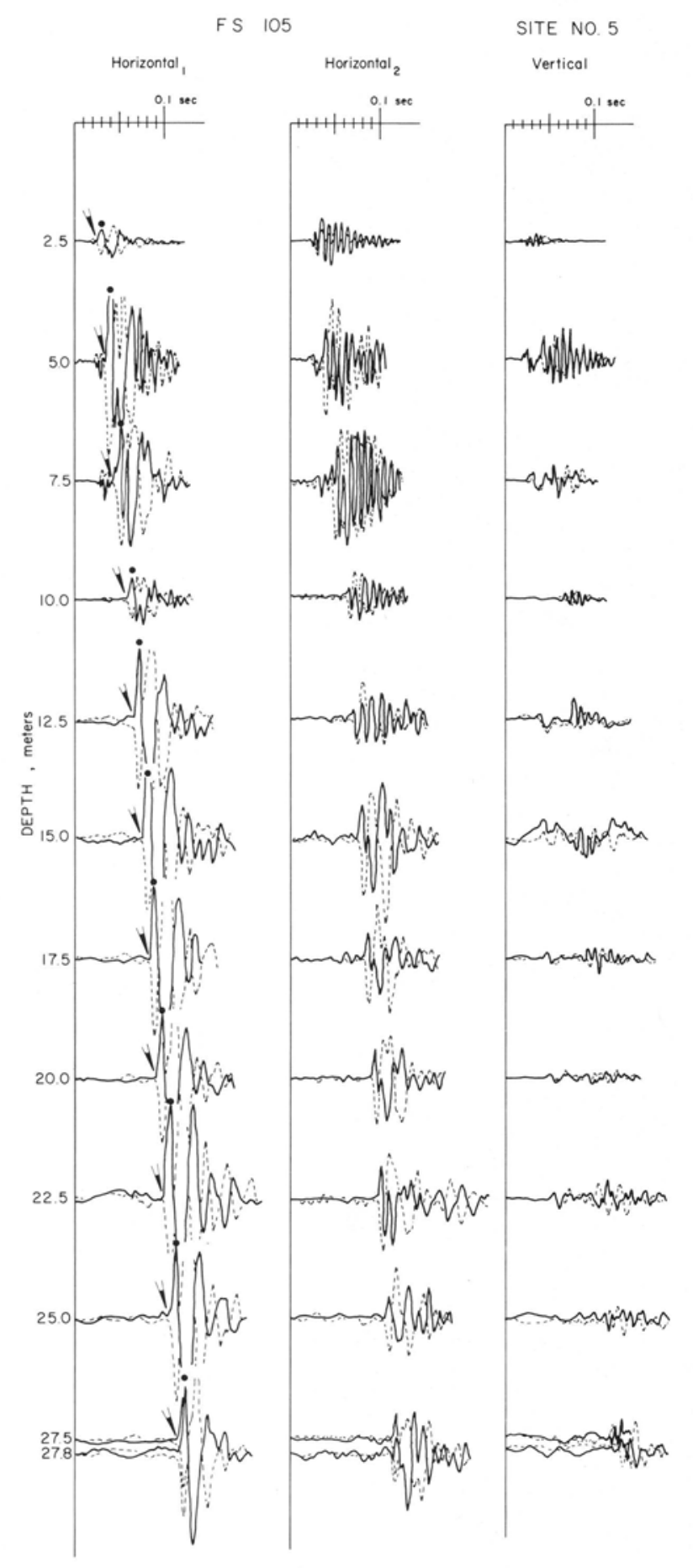

Figure 57.

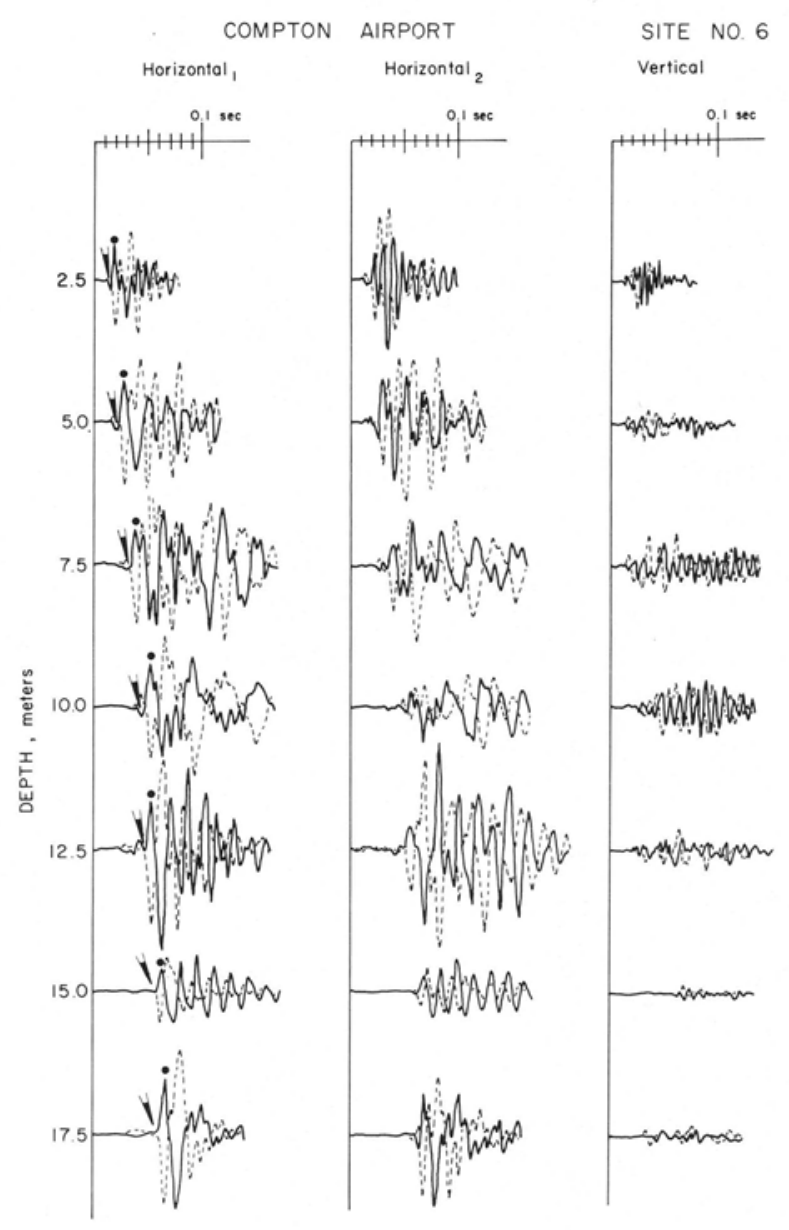

Figure 58. 


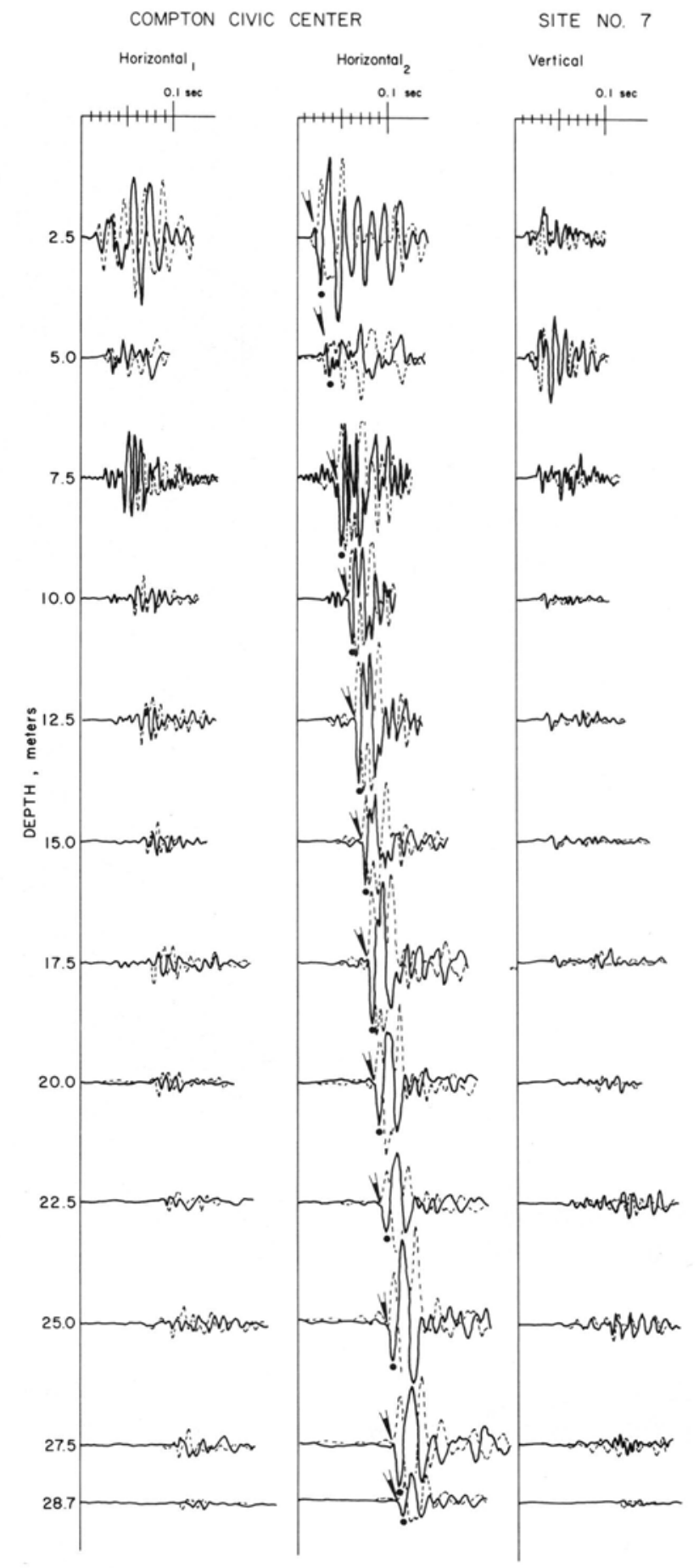

Figure 59.

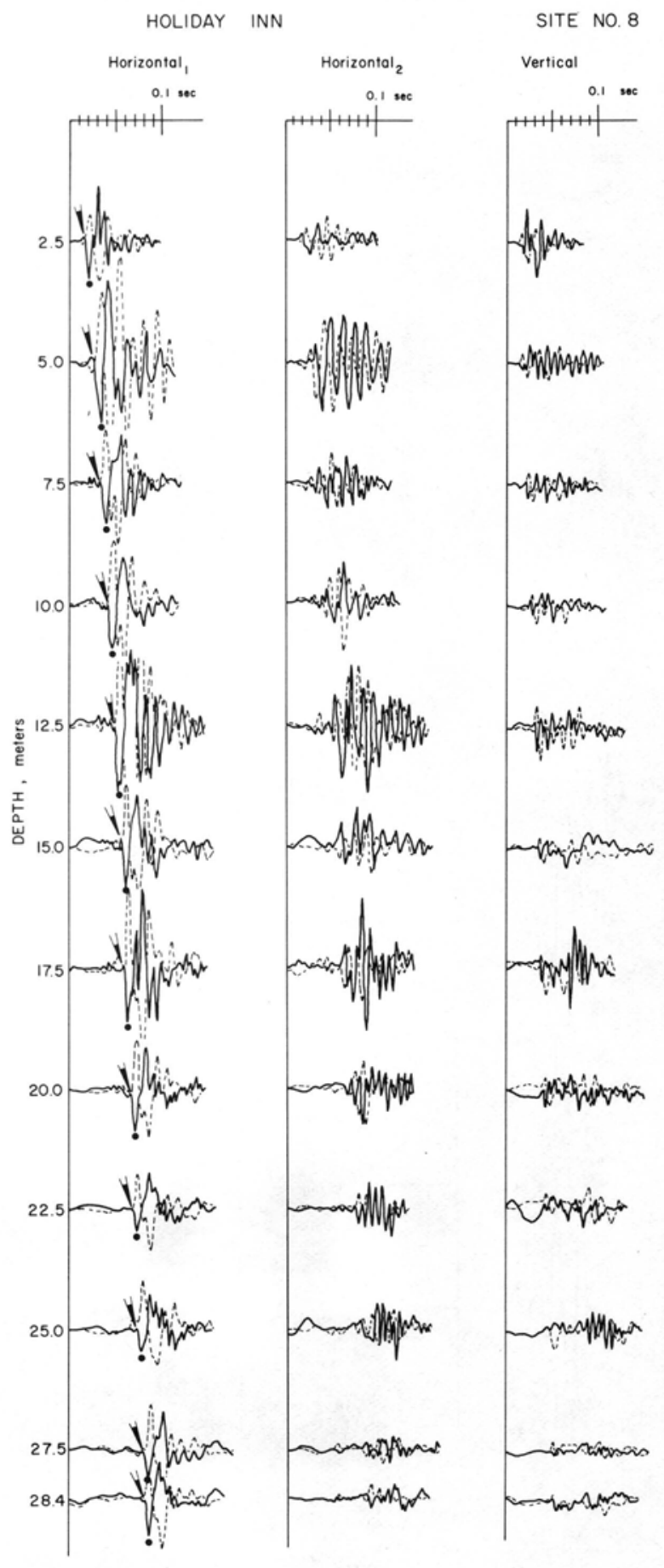

Figure 60. 


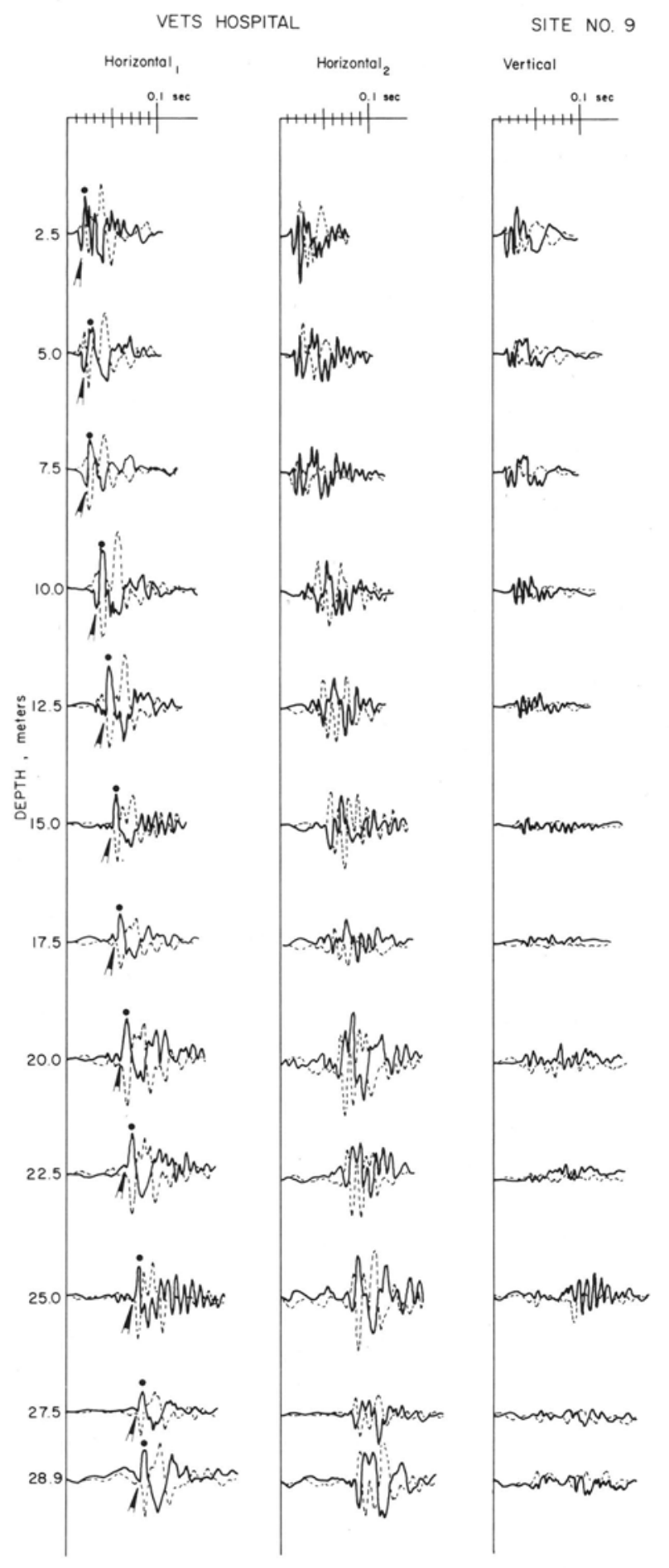

Figure 61.

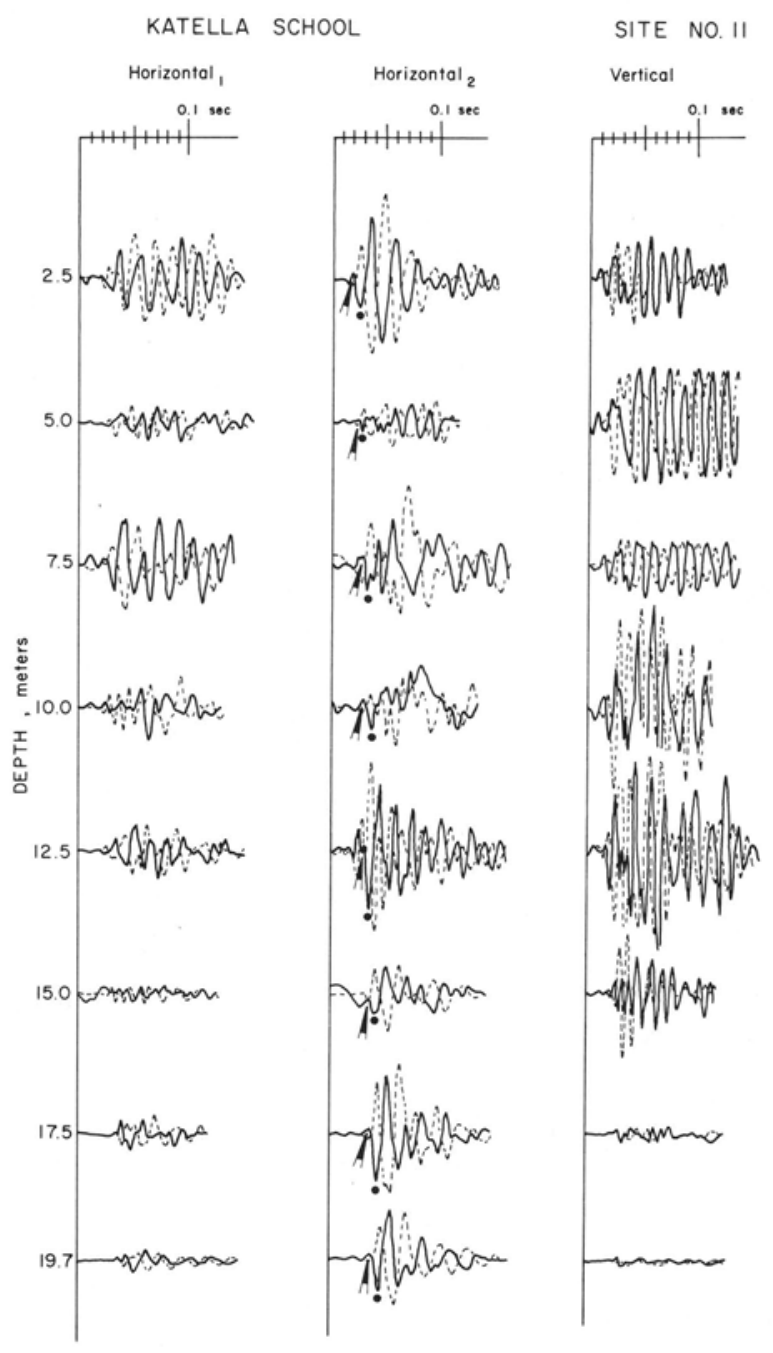

Figure 62. 


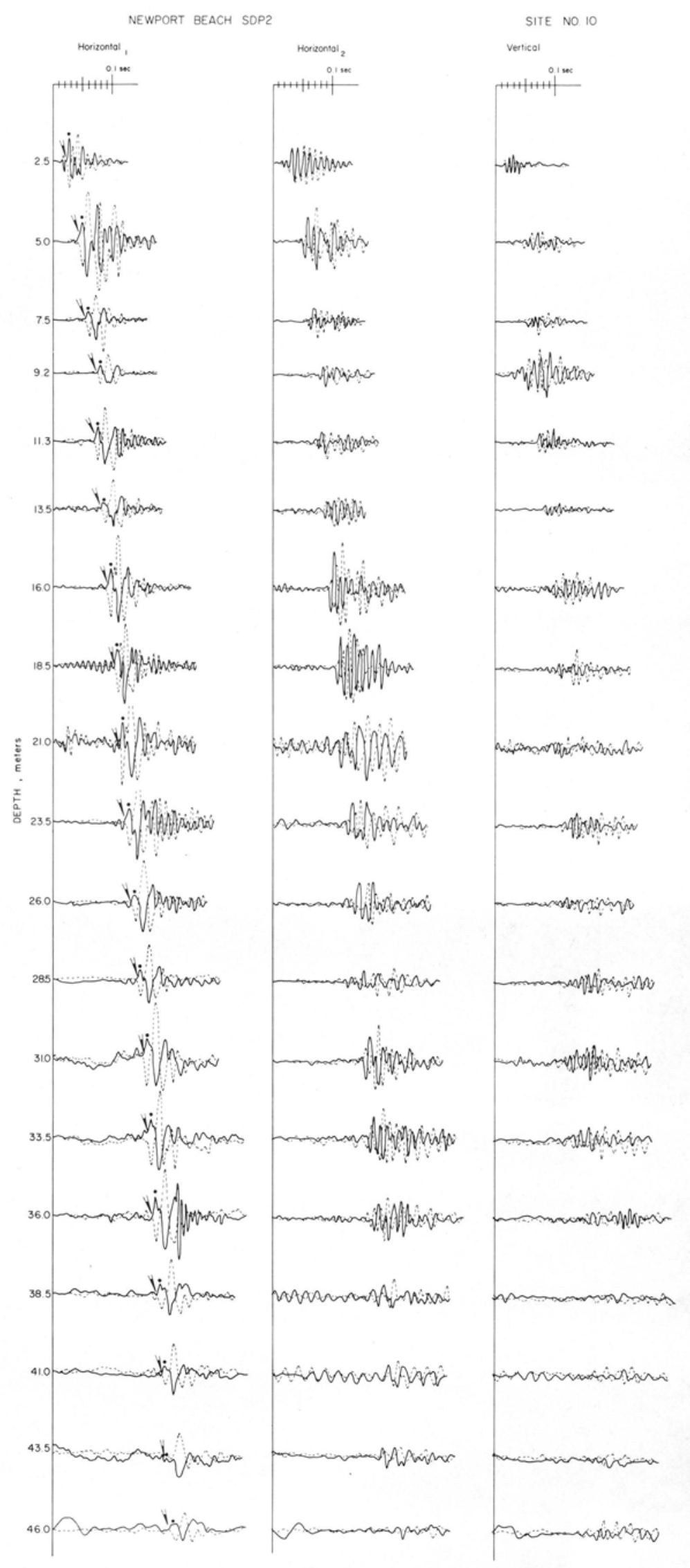

Figure 63. 


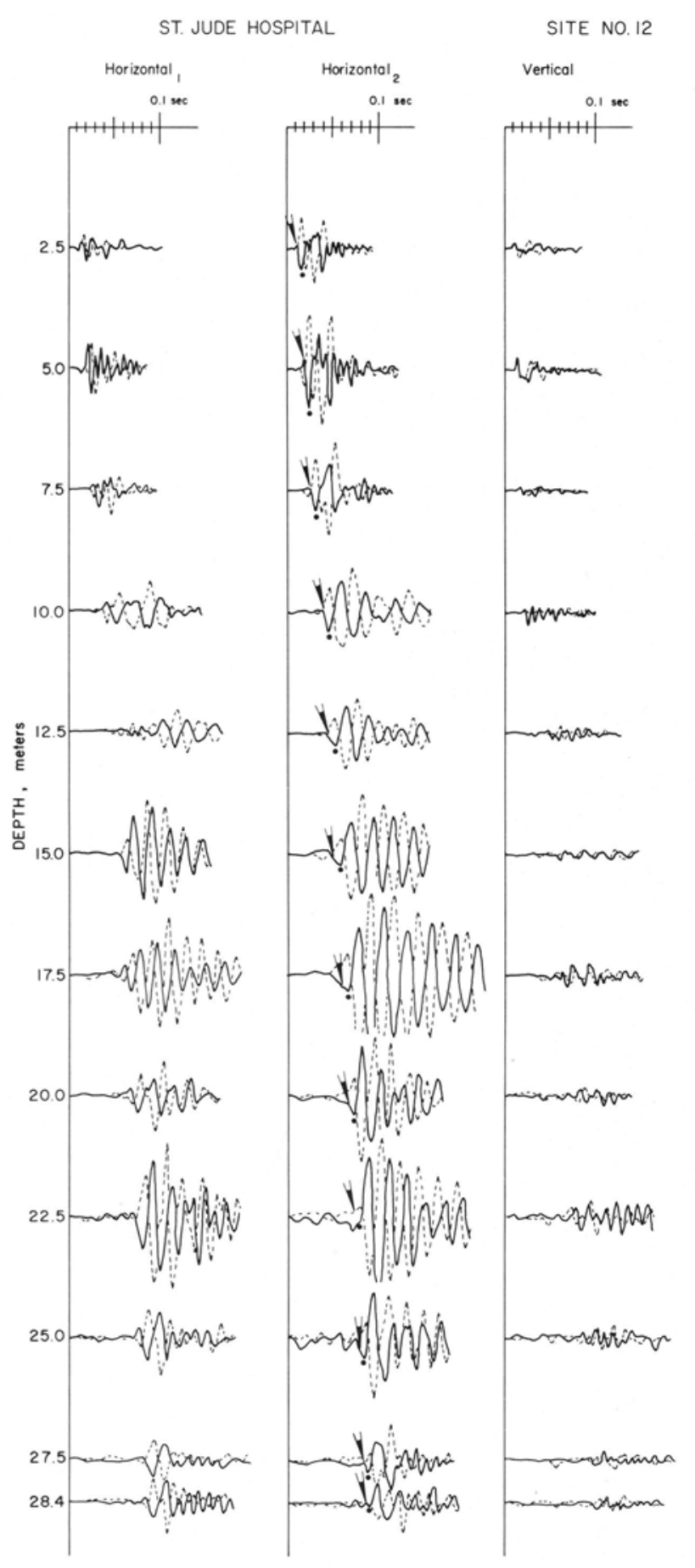

Figure 64

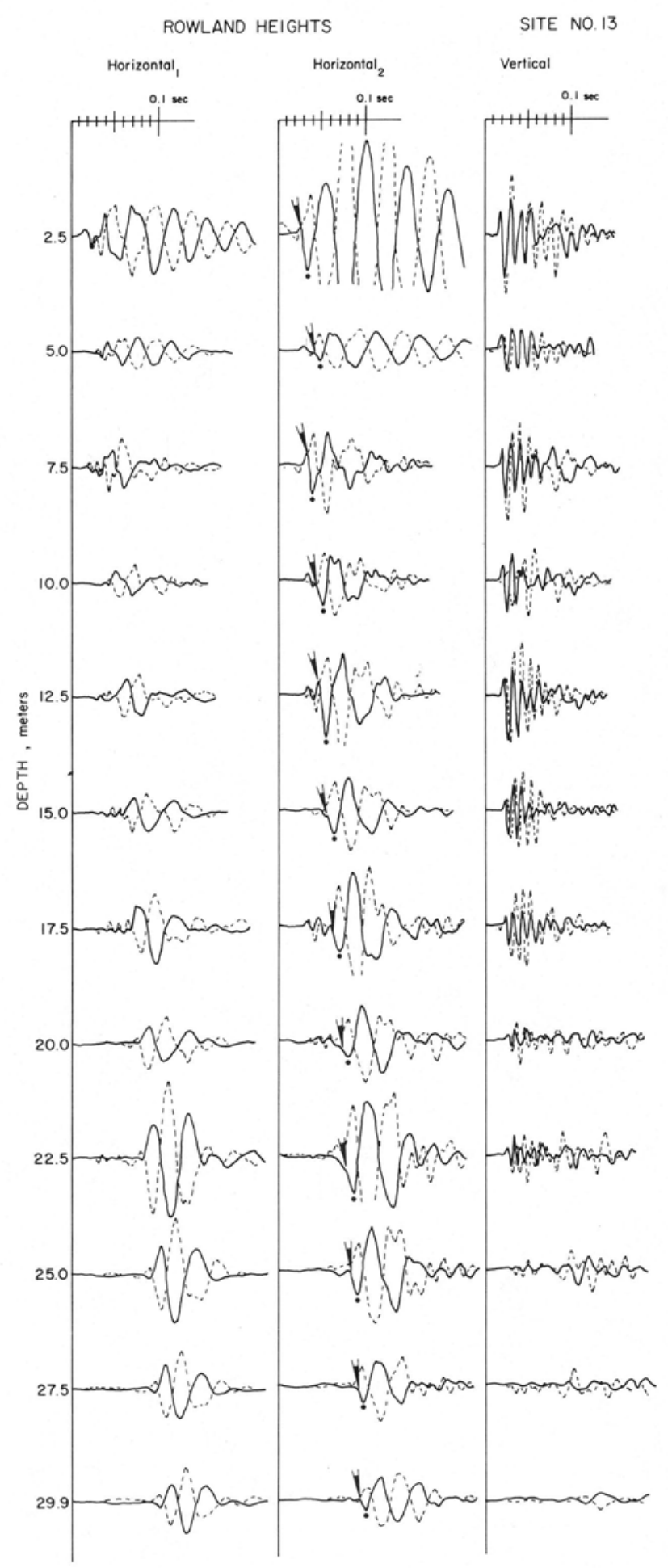

Figure 65 


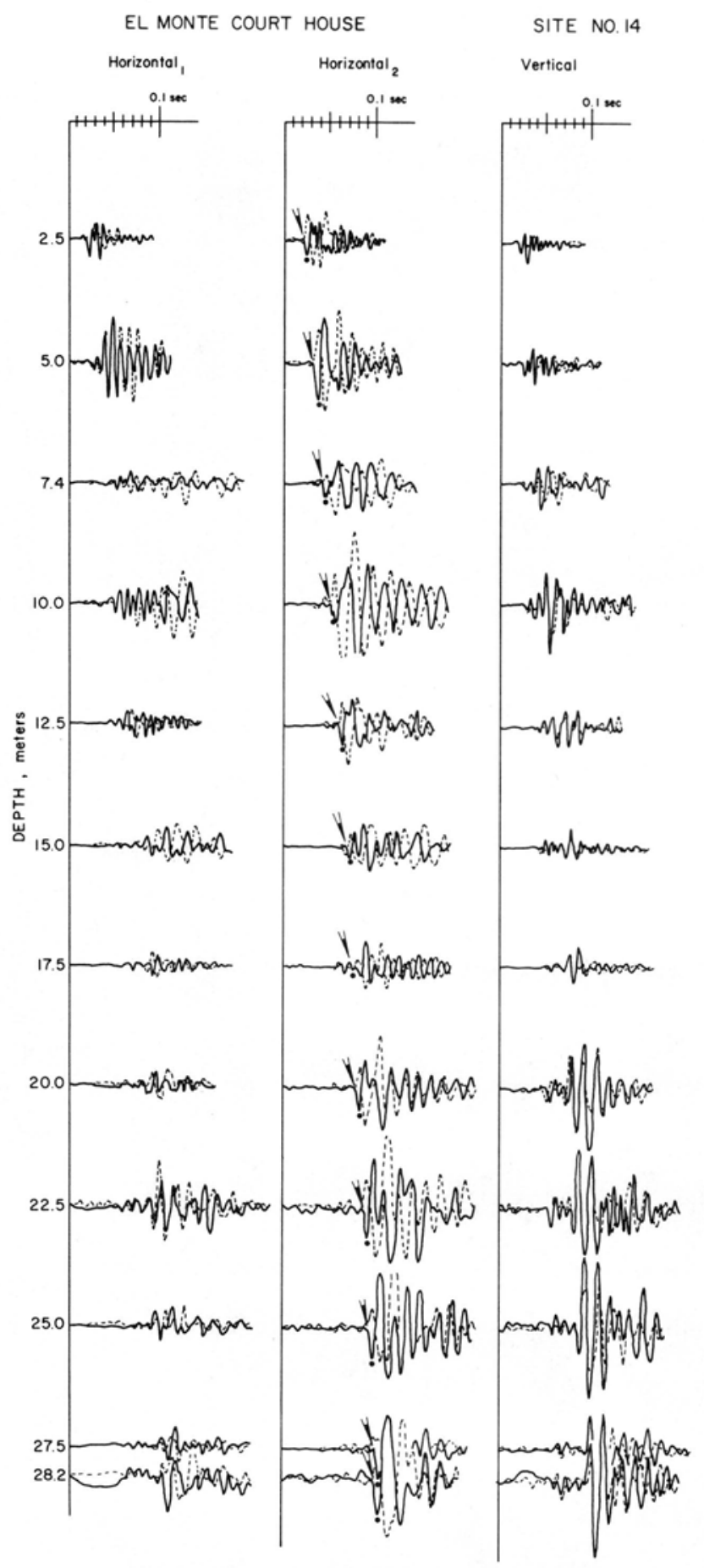

Figure 66

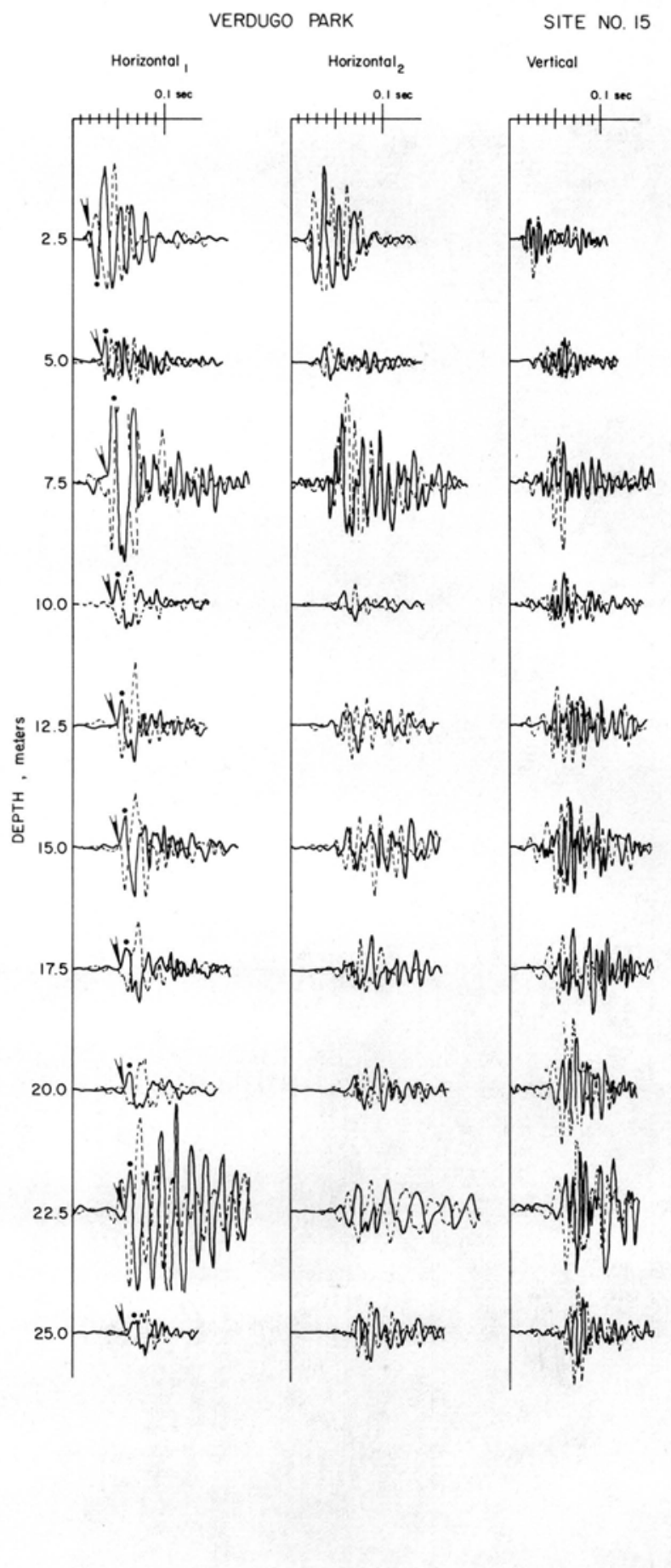

Figure 67 


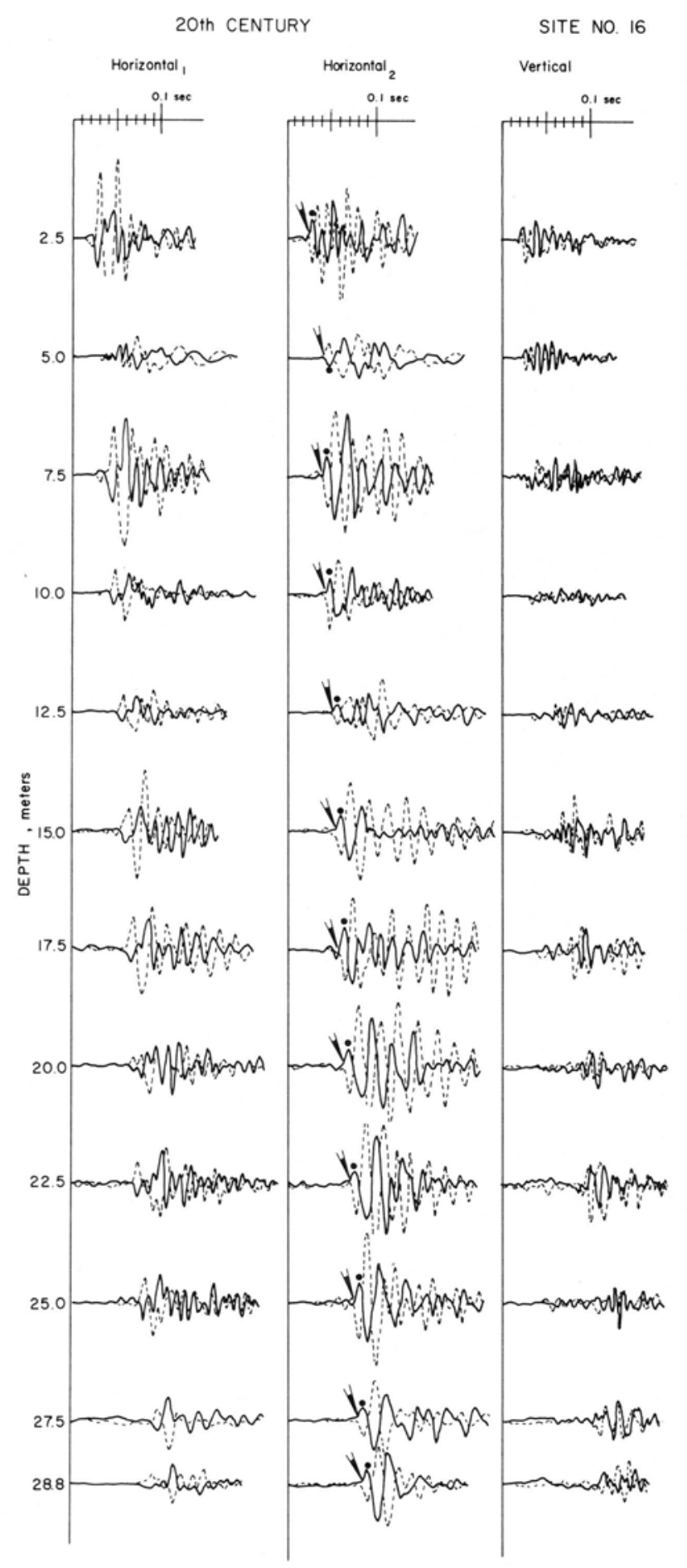

Figure 68.

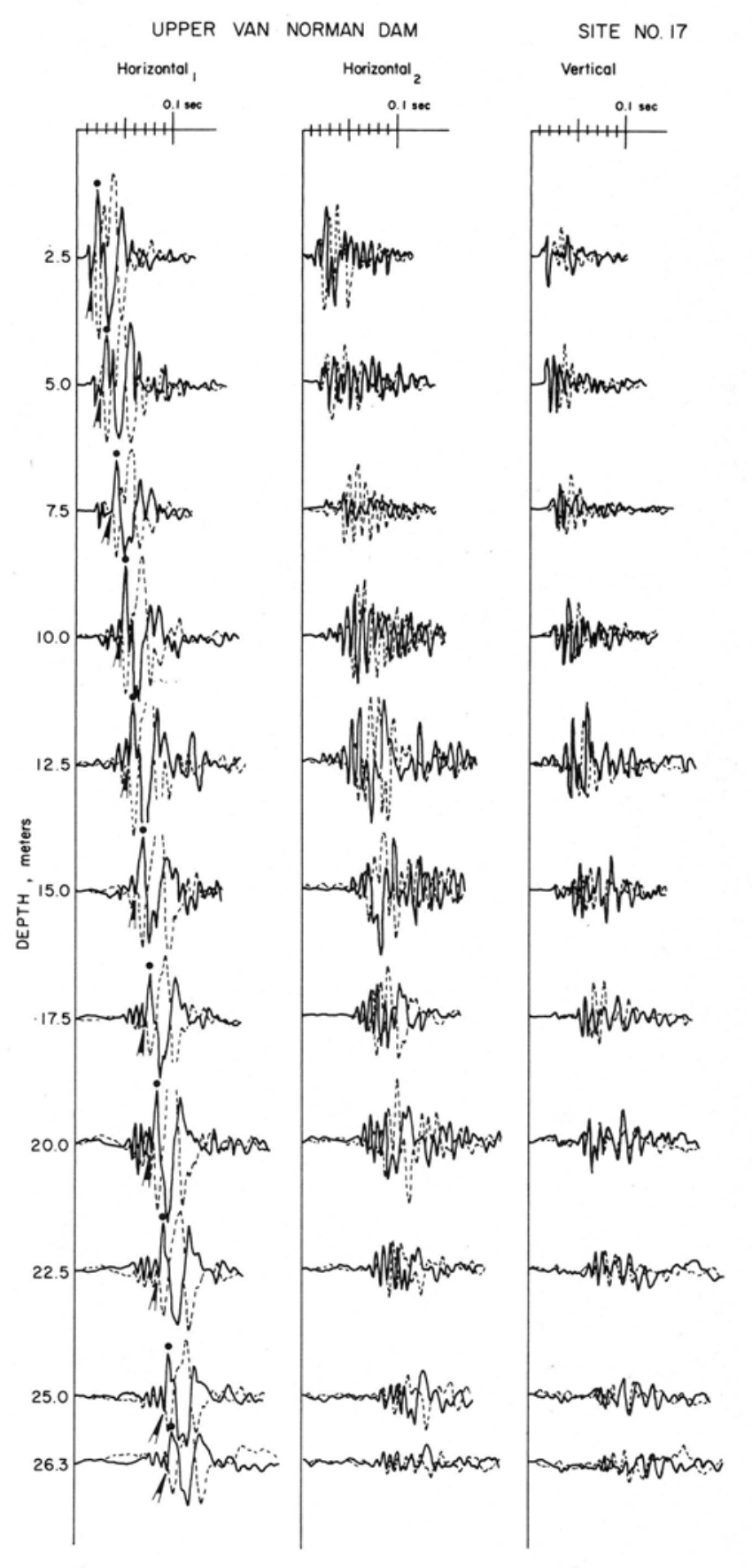

Figure 69. 


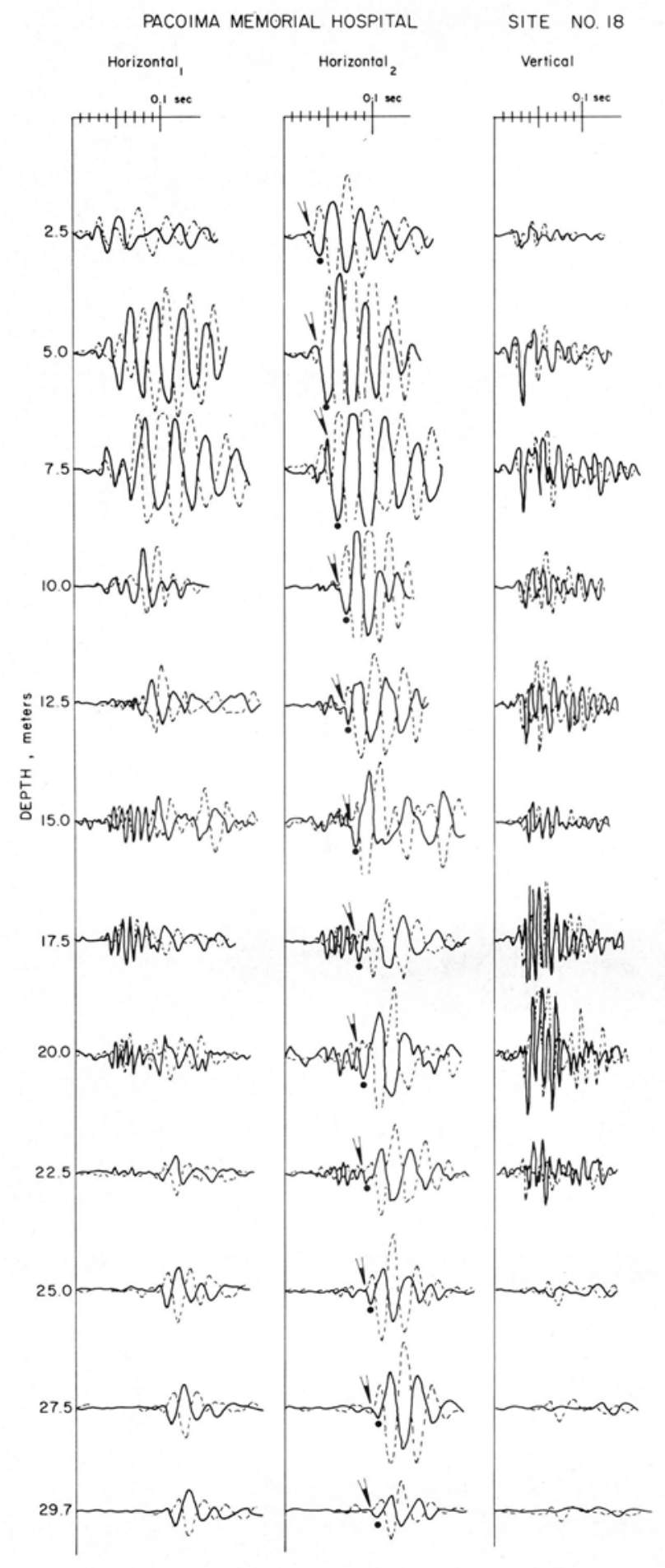

Figure 70.

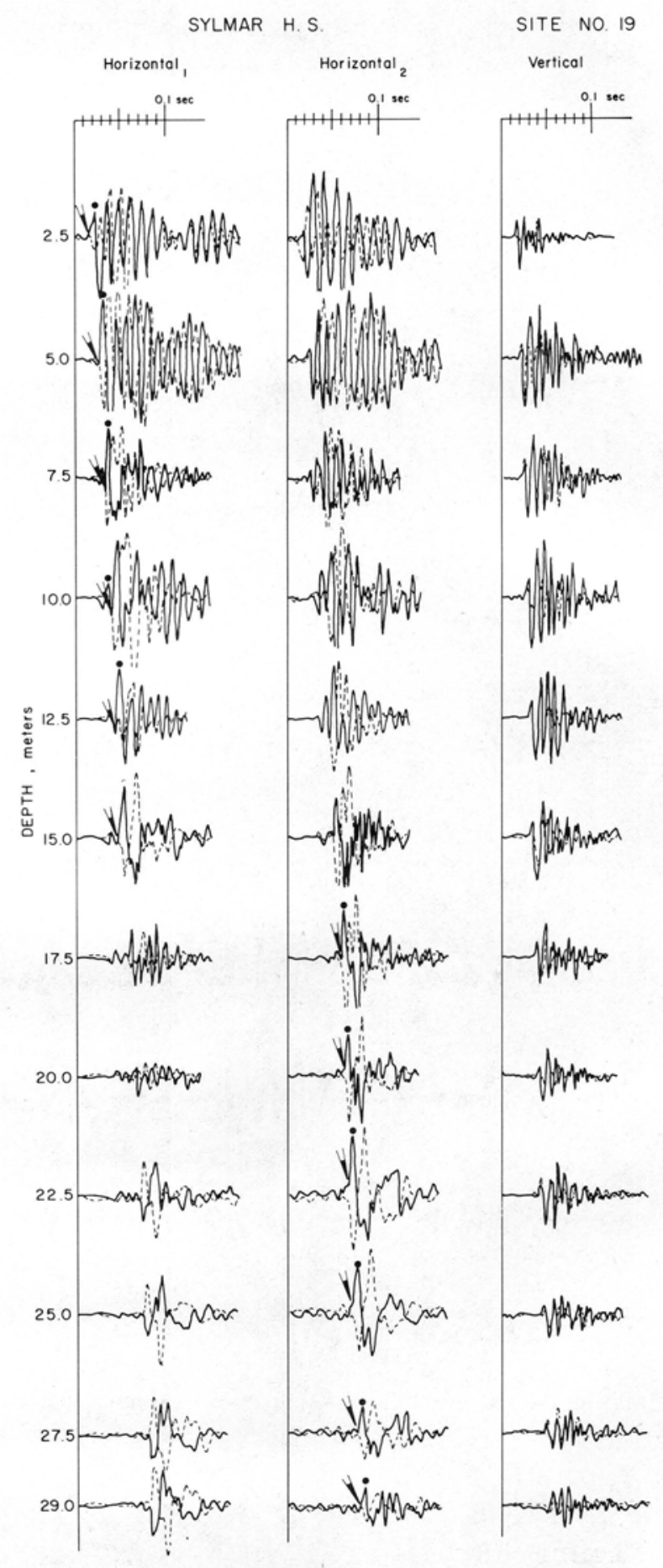

Figure 71. 


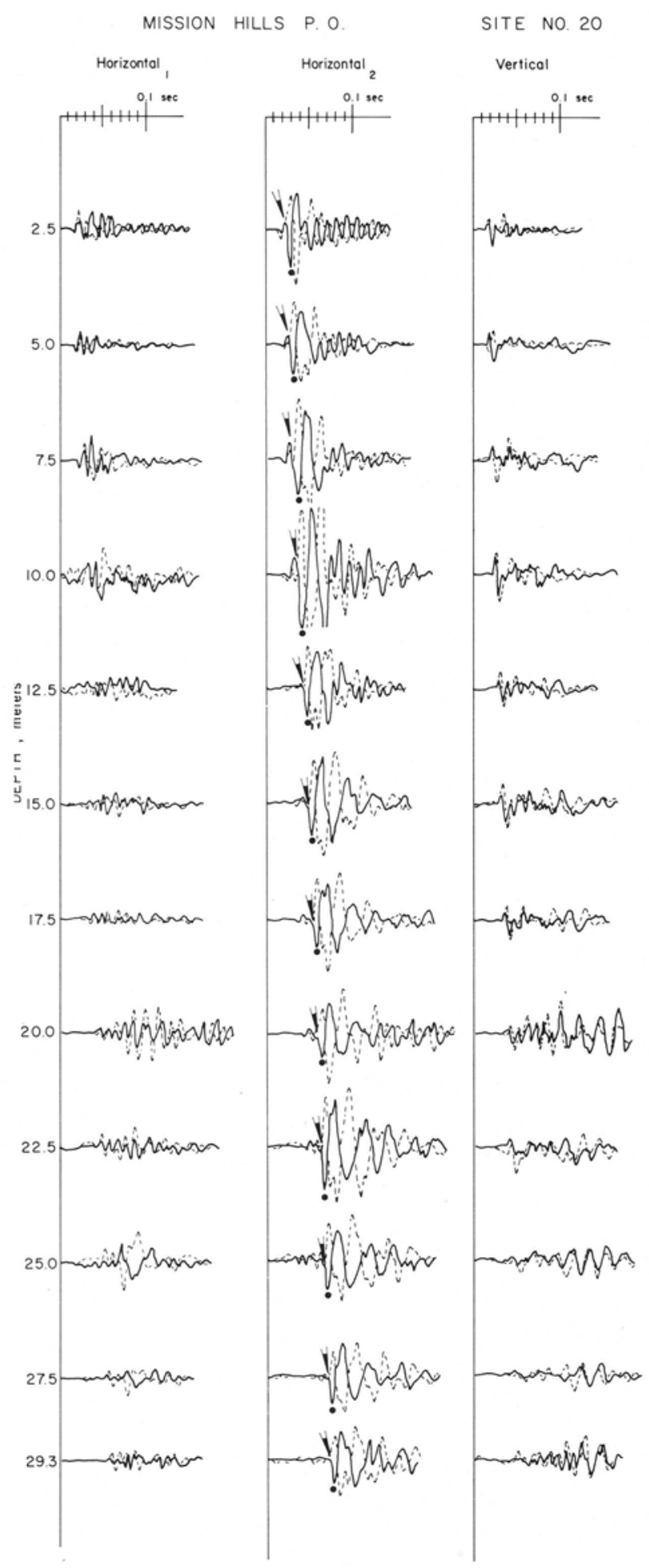

Figure 72 .

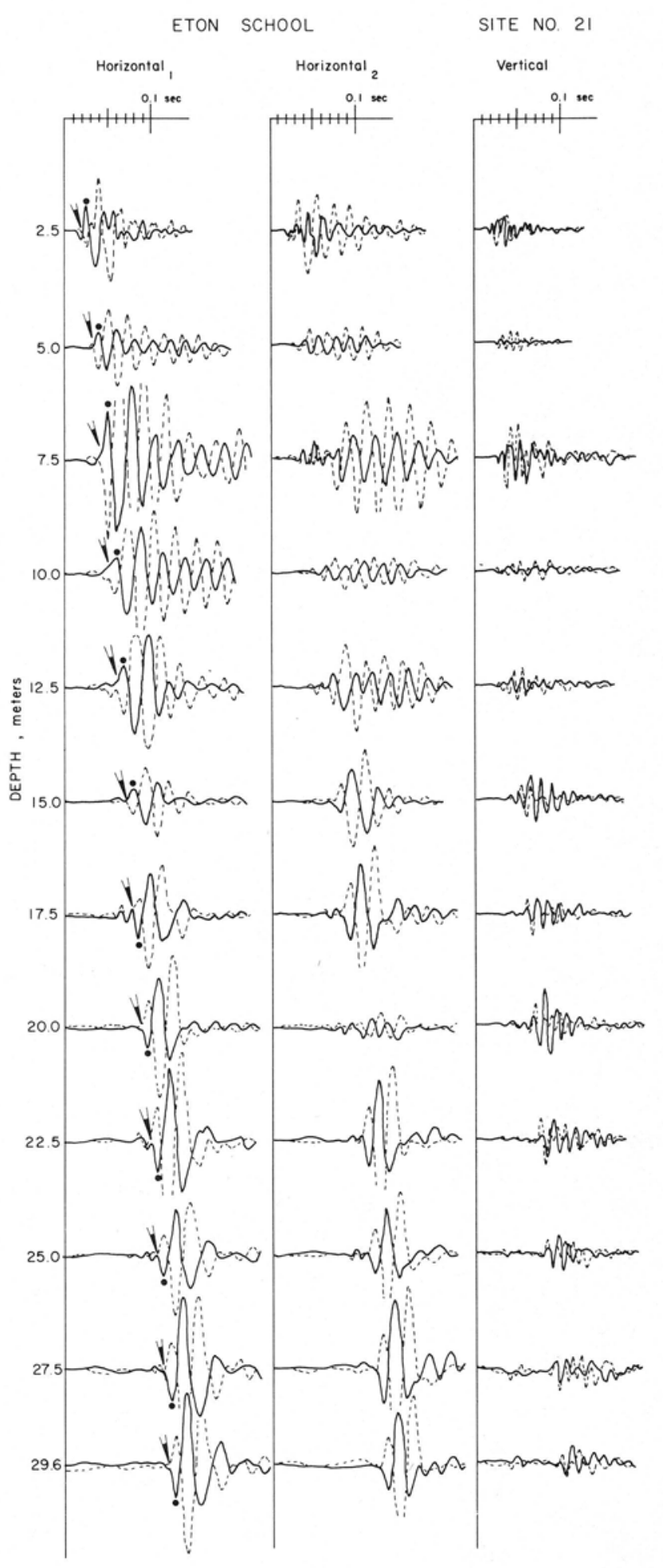

Figure 73. 


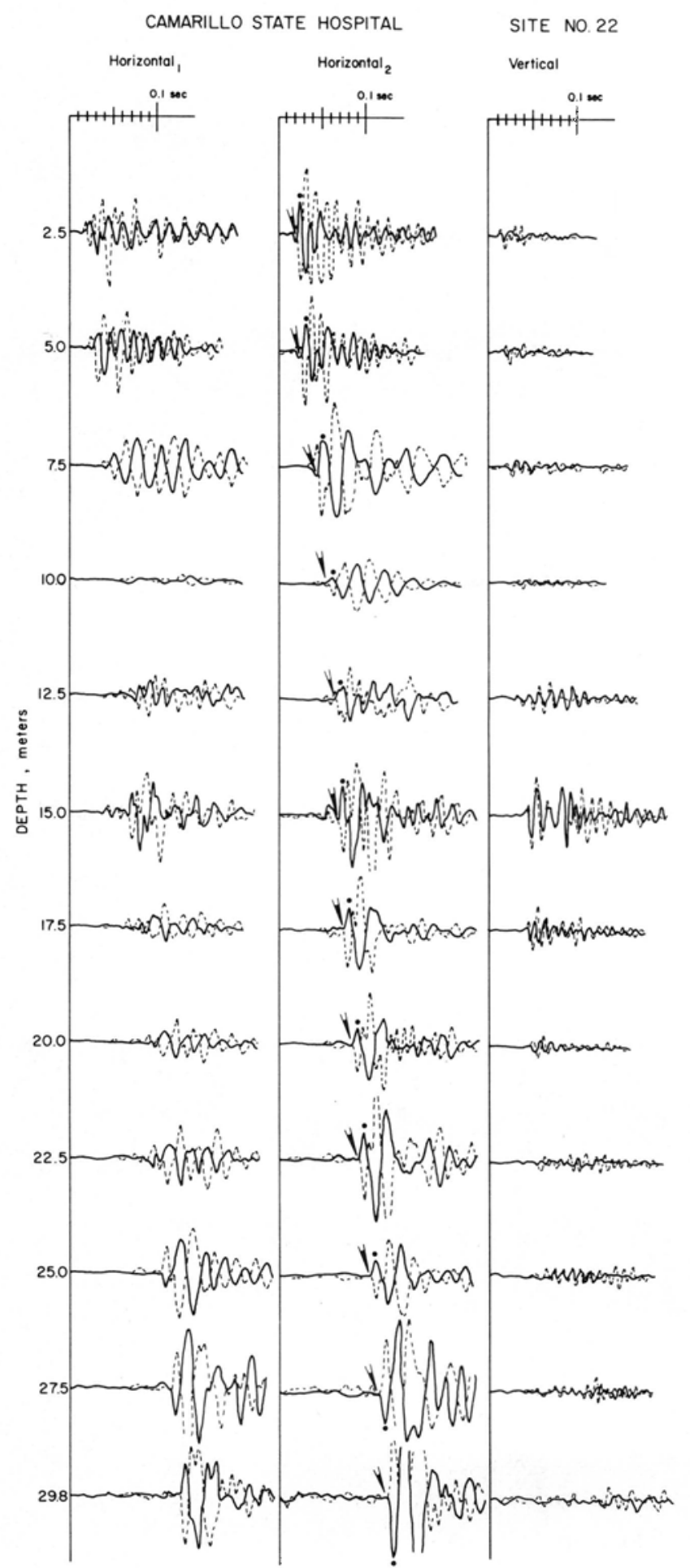

Figure 74.

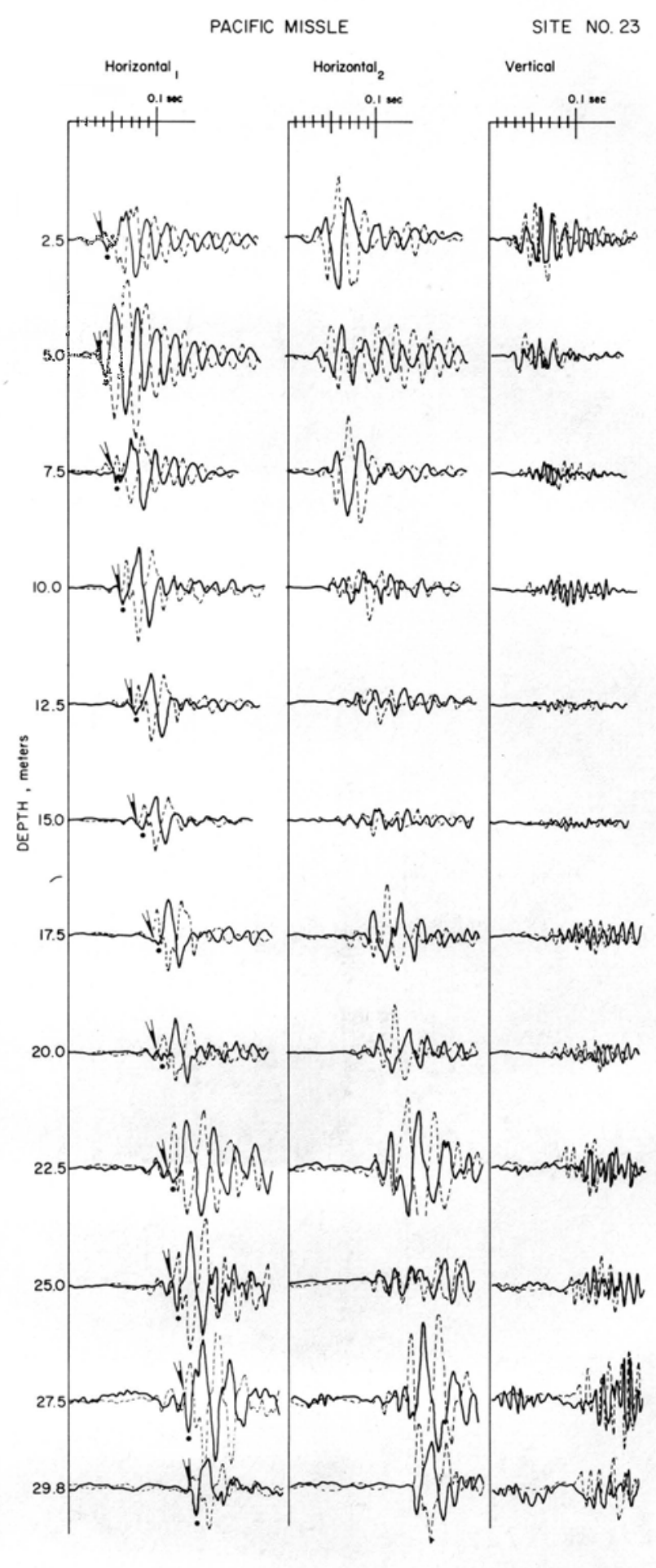

Figure 75. 


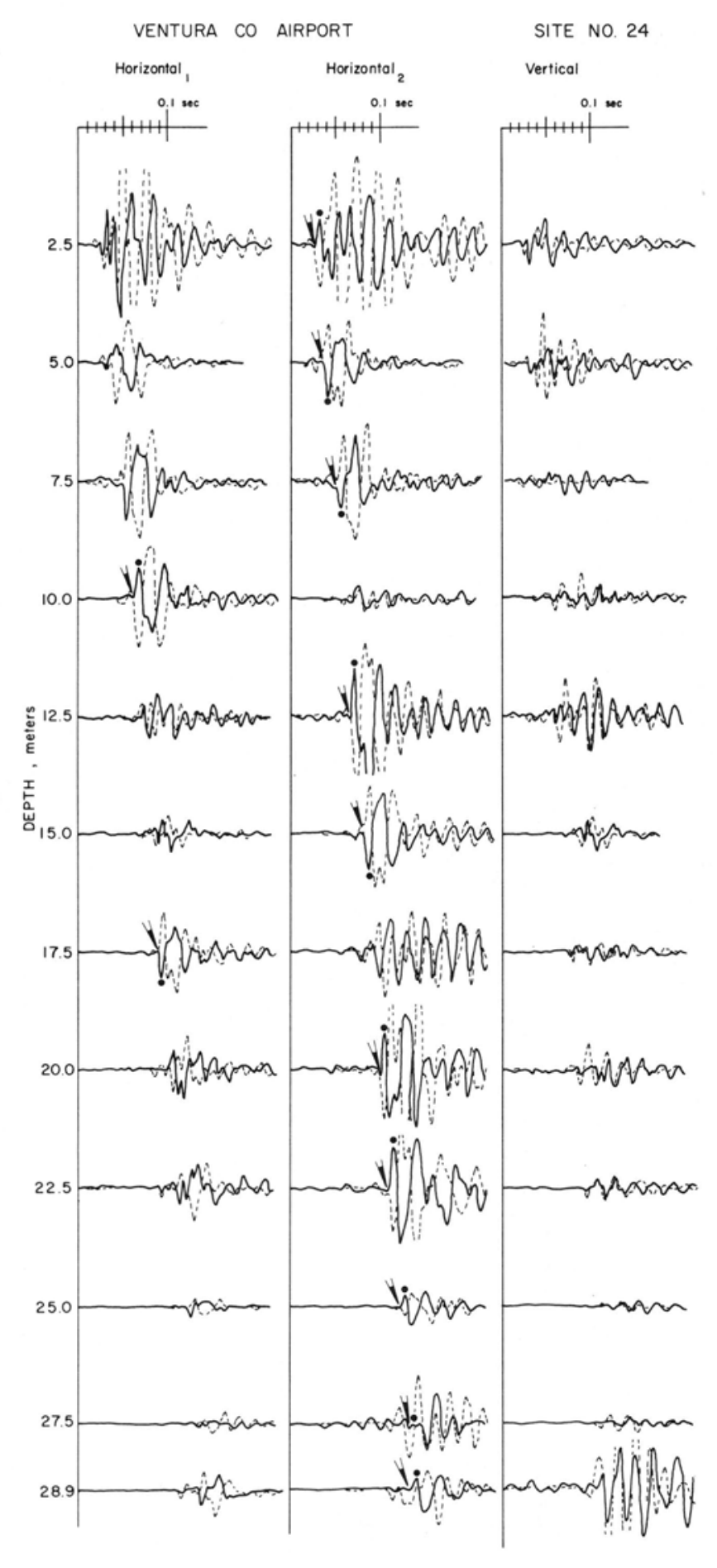

Figure 76.

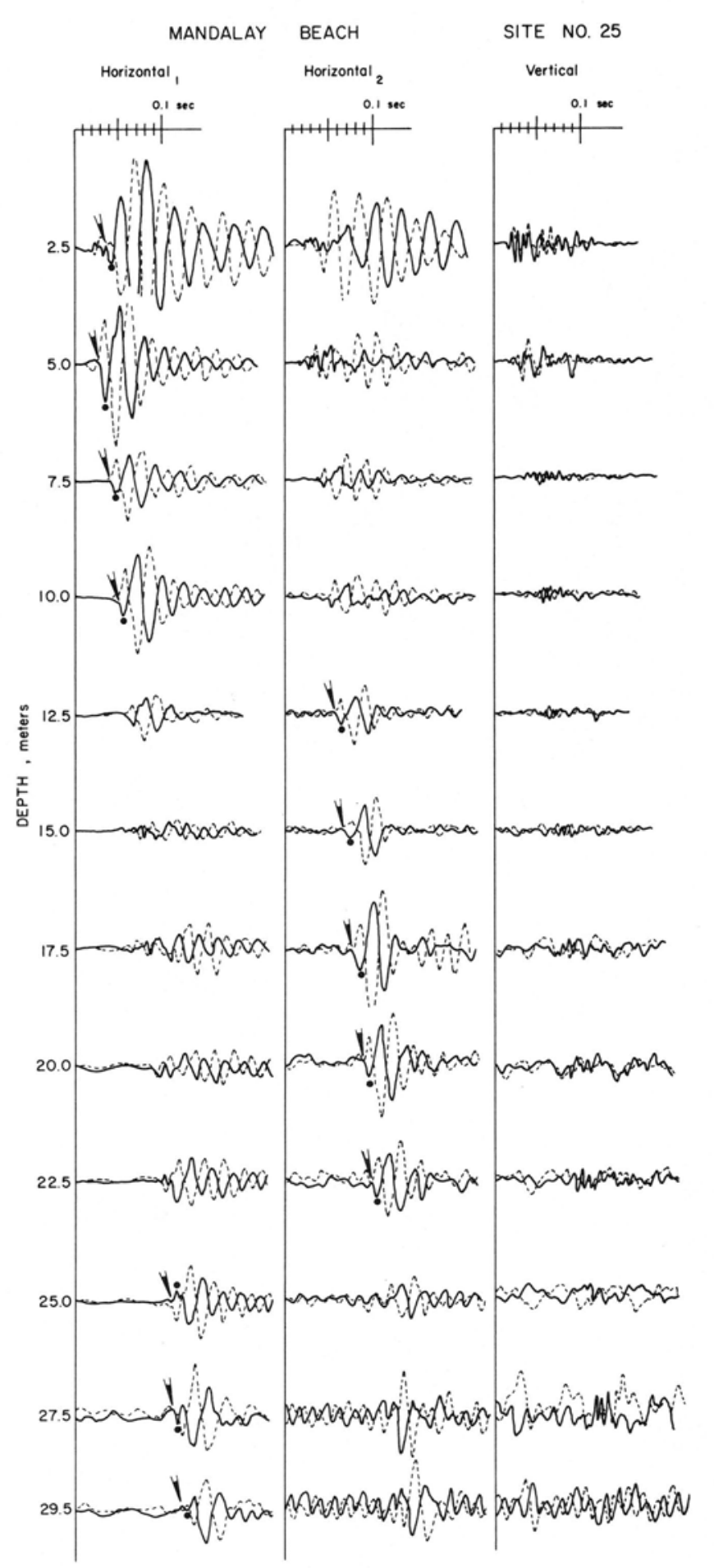

Figure 77. 


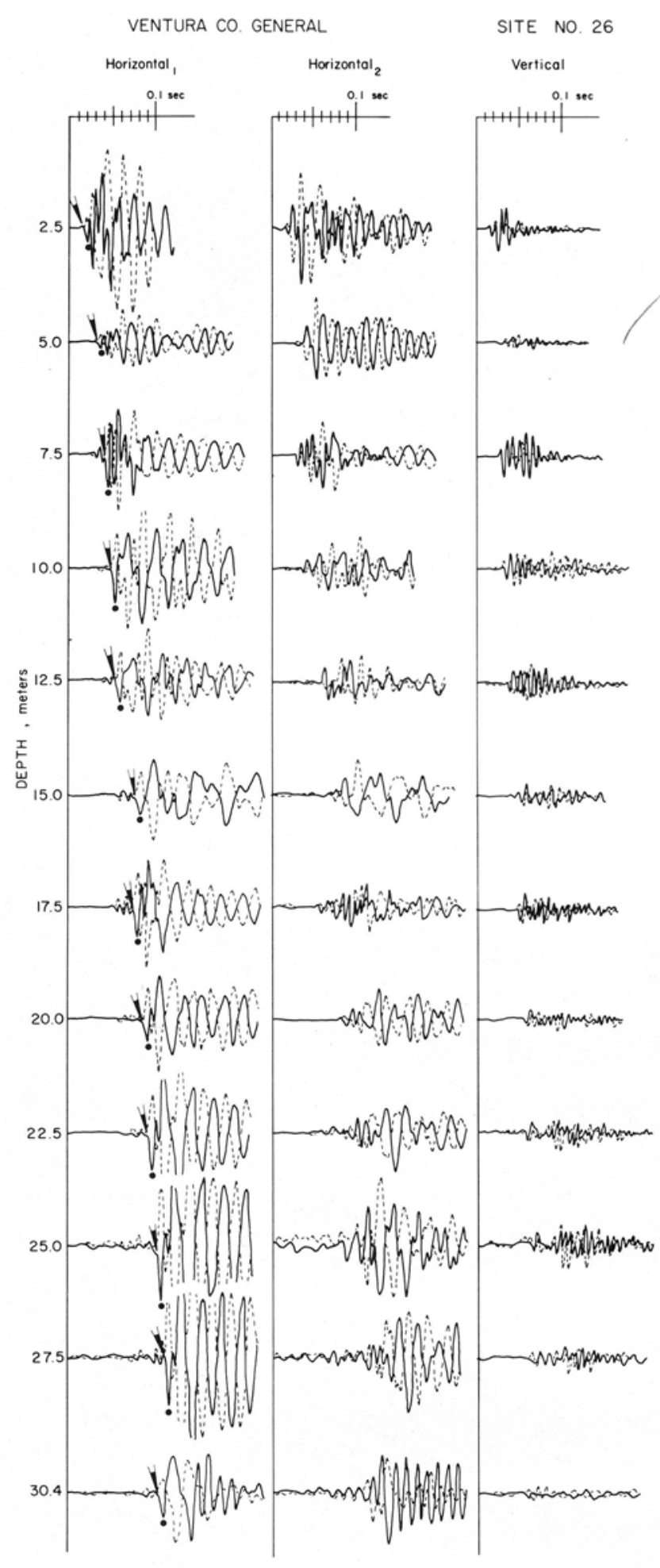

Figure 78

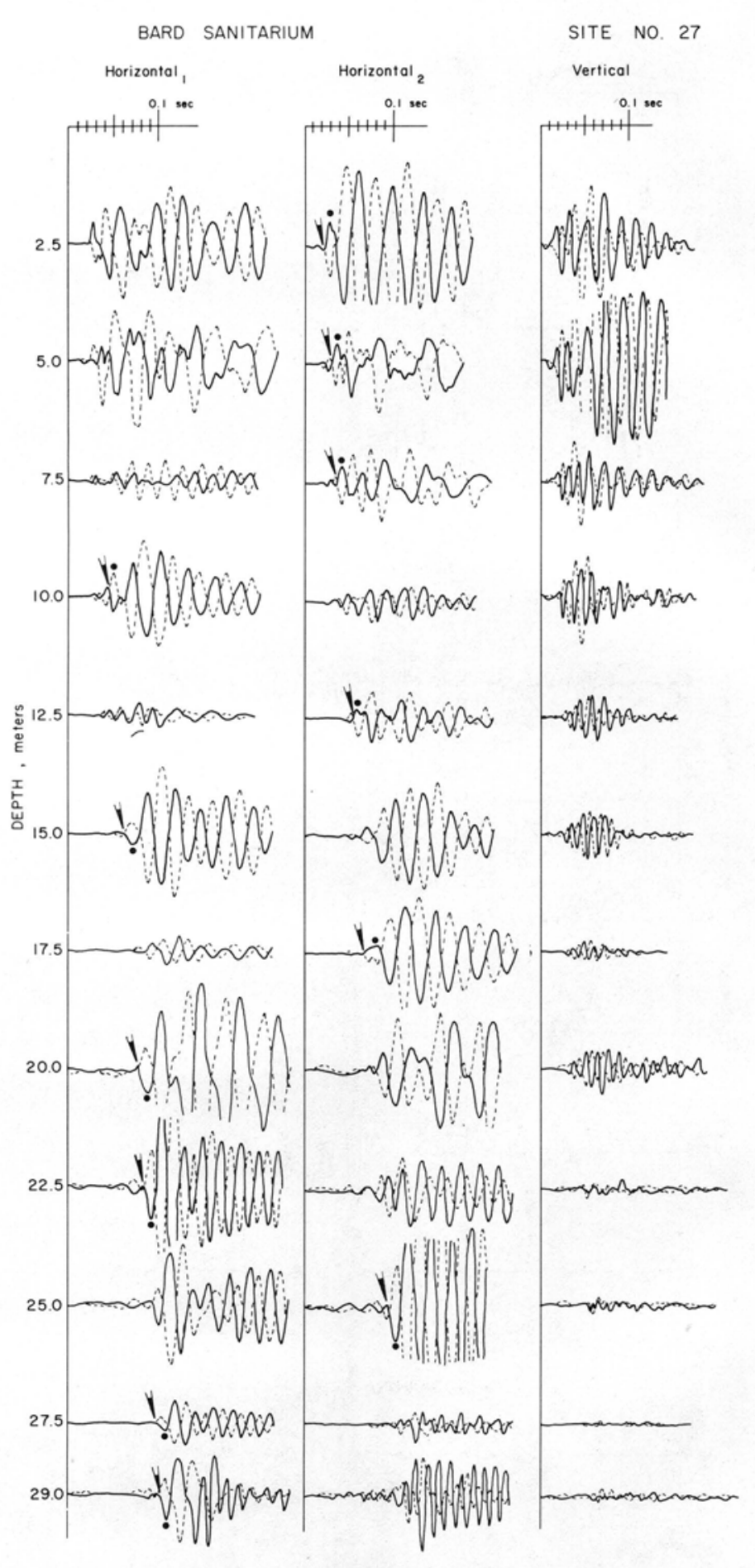

Figure 79 


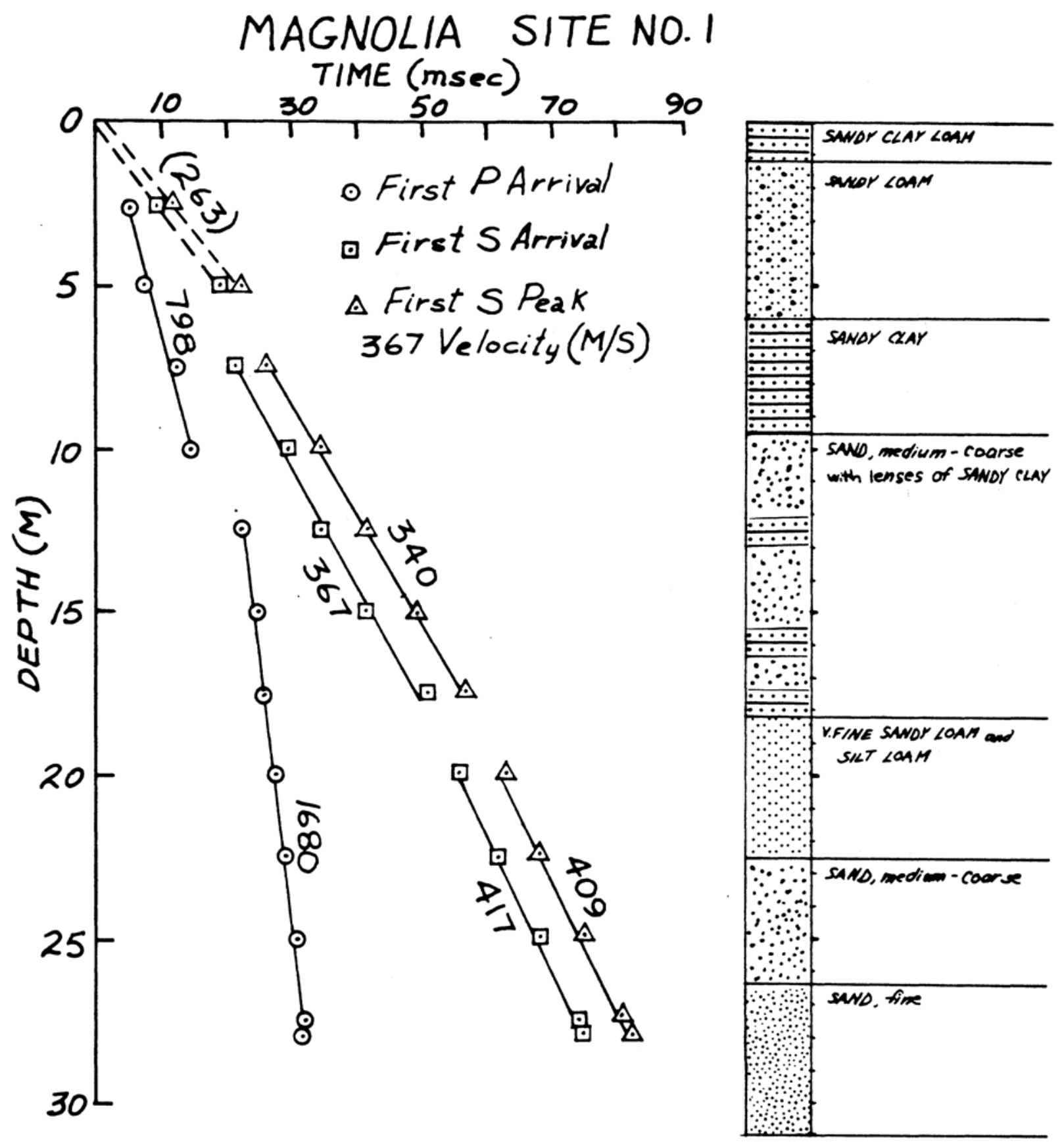

Figure 80 . 


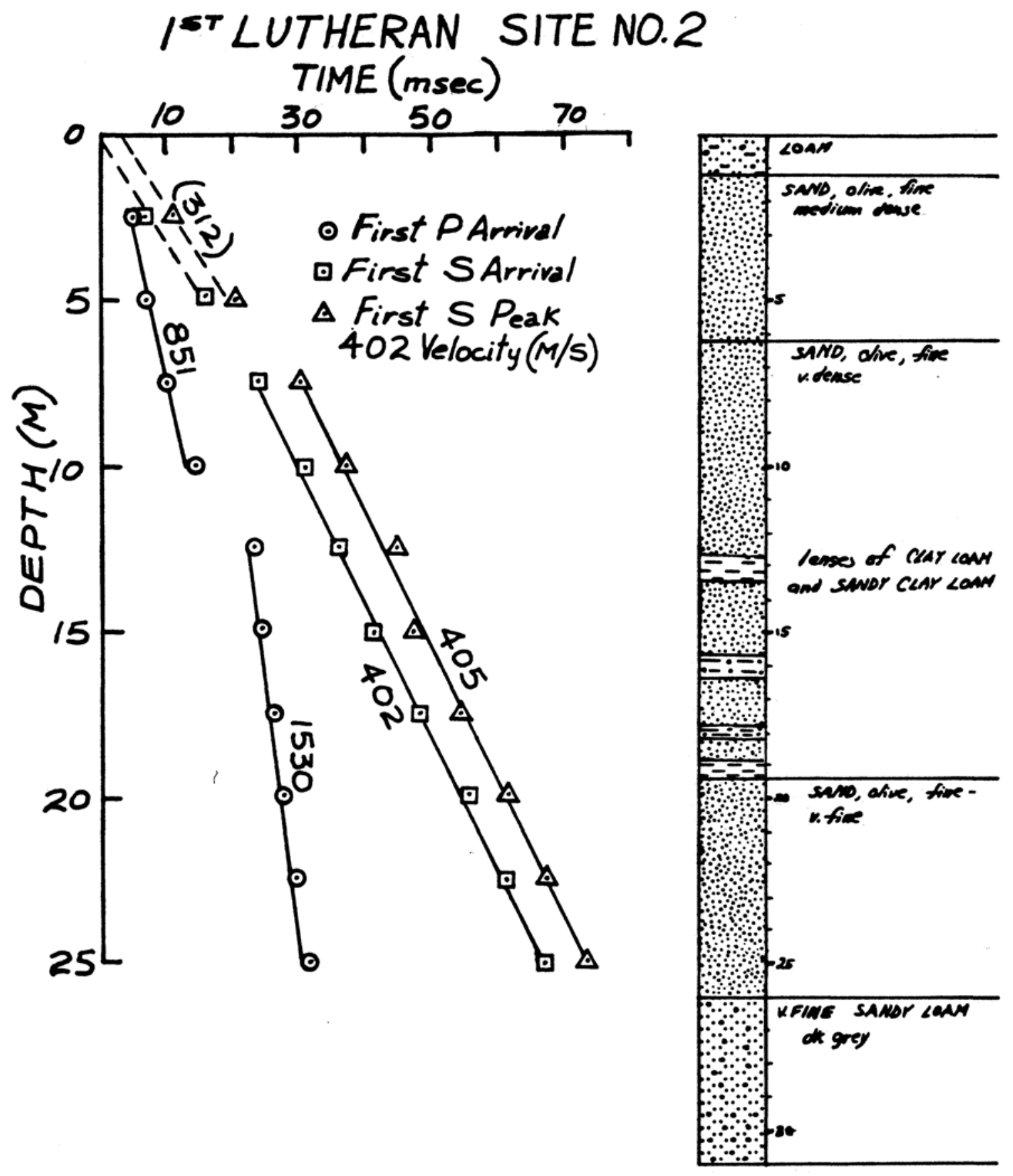

Figure 81. 

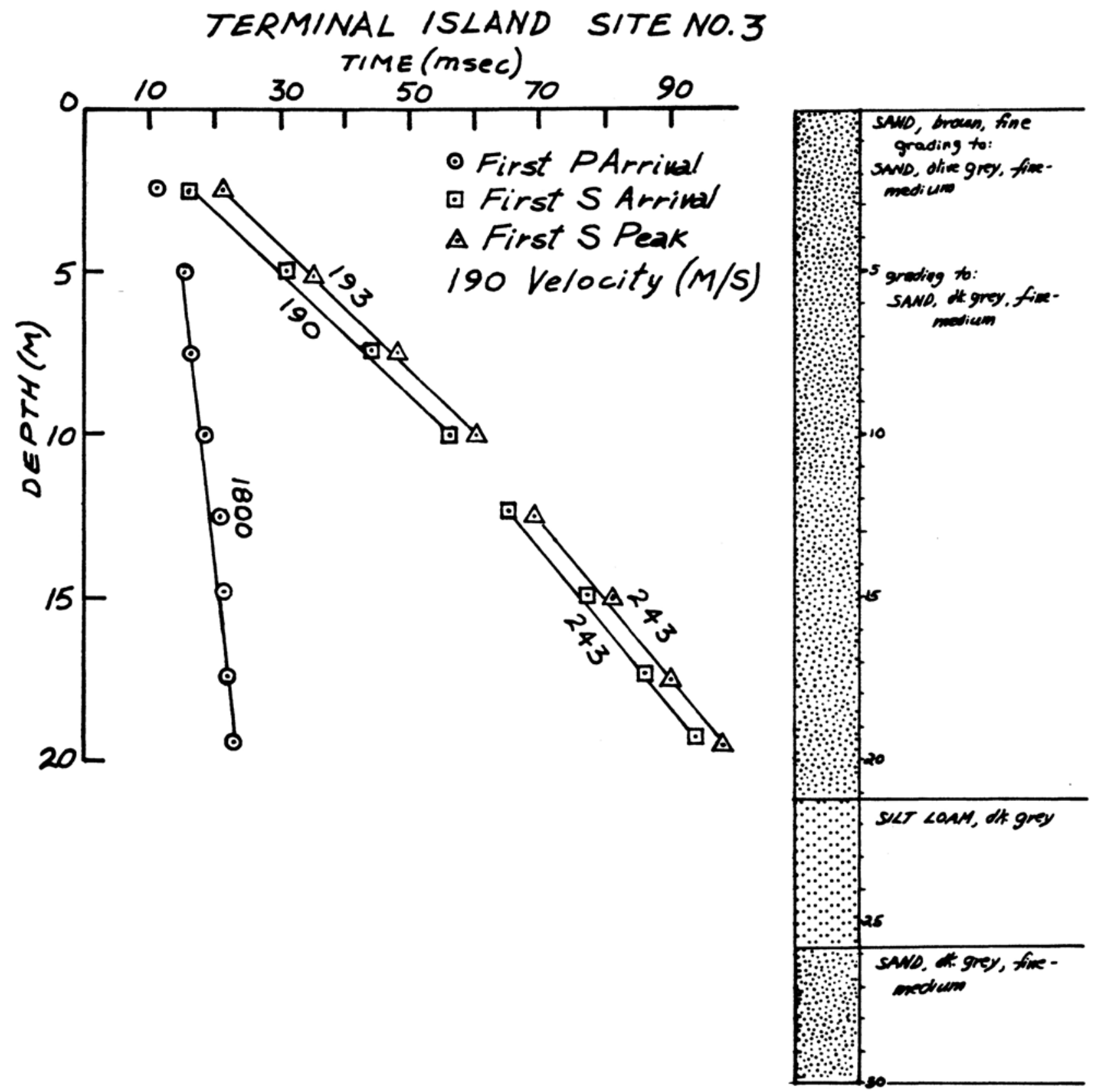

Figure 82 . 

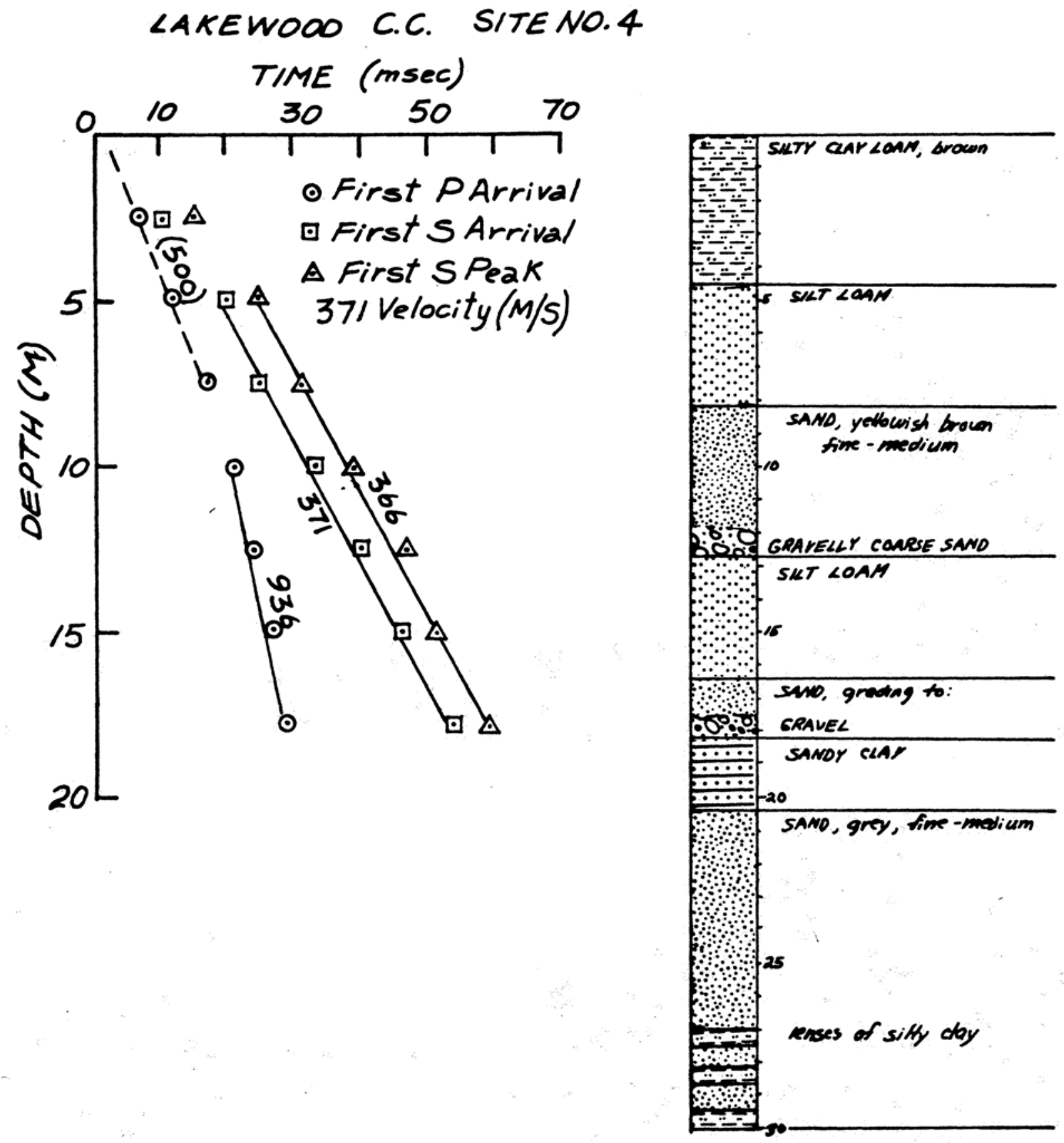

Figure 83. 


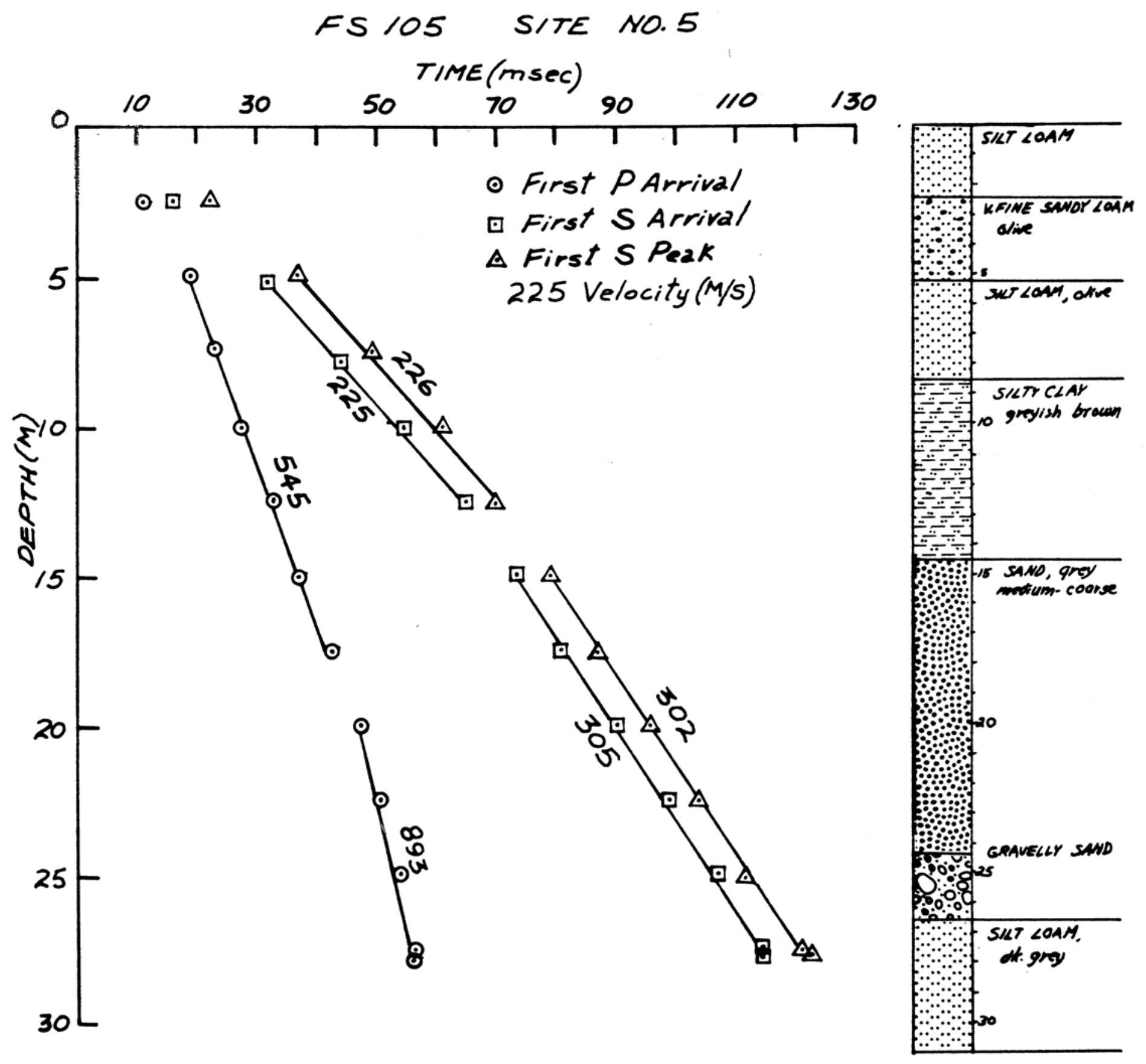

Figure 84 . 


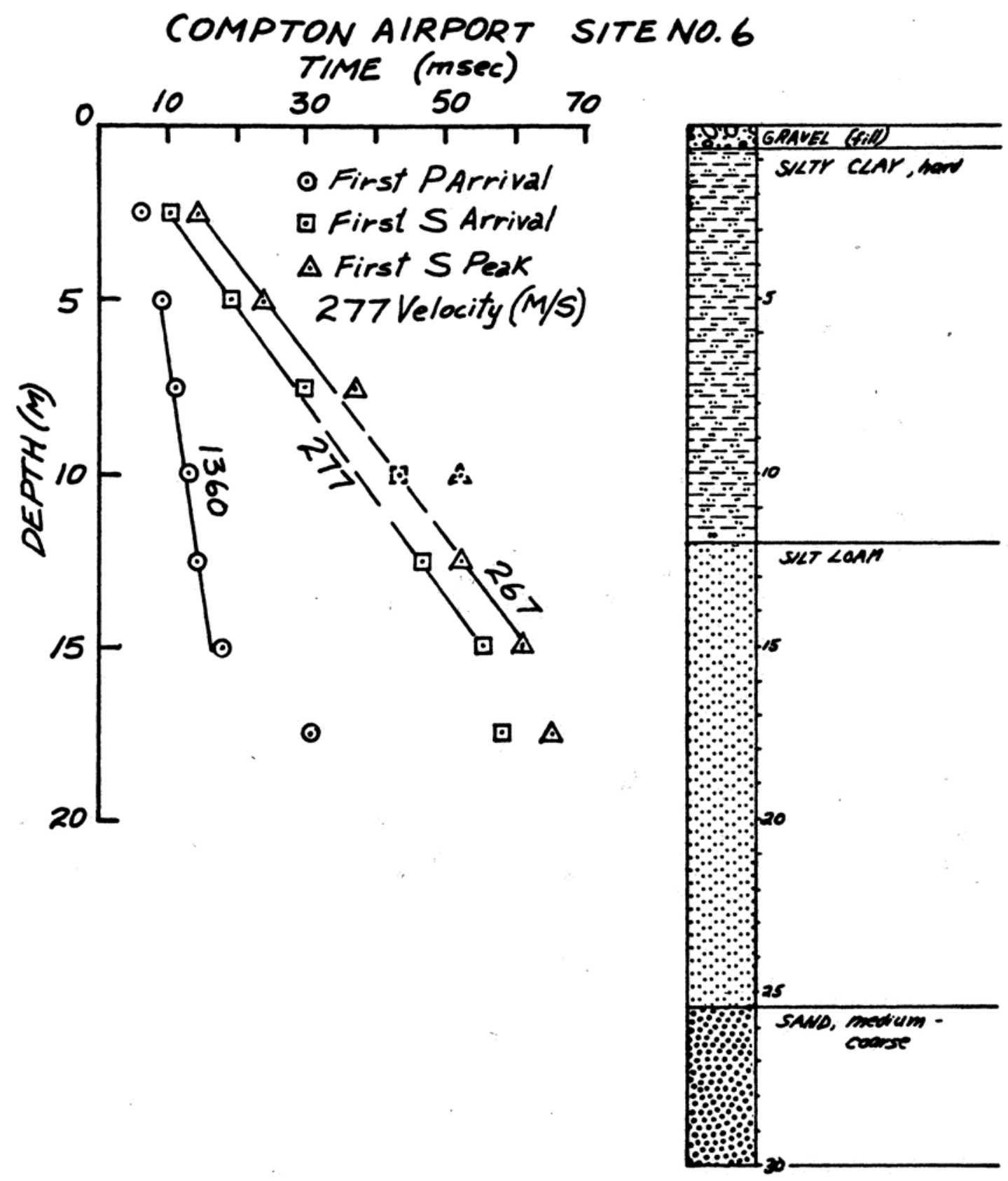

Figure 85. 


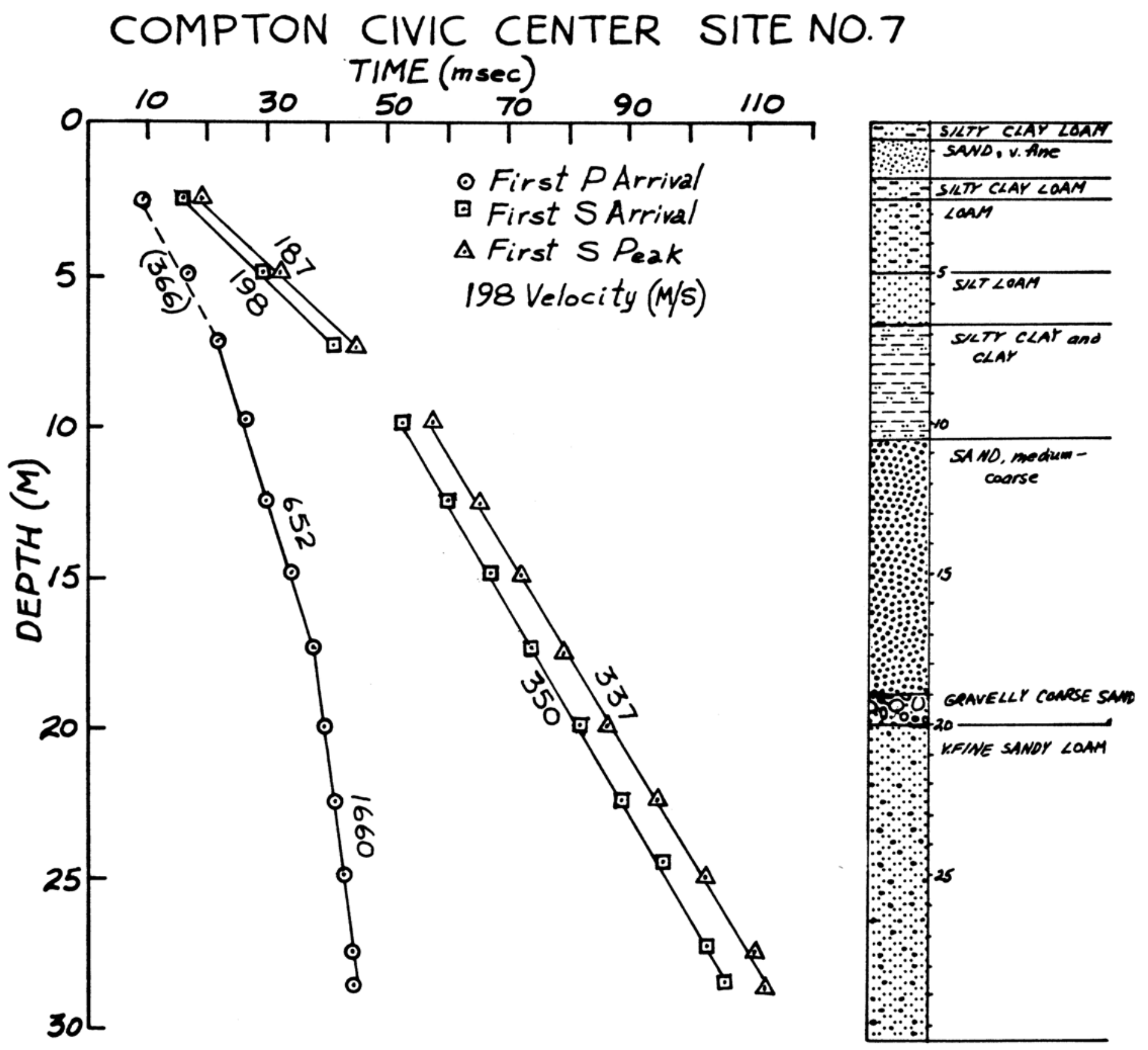

Figure 86. 


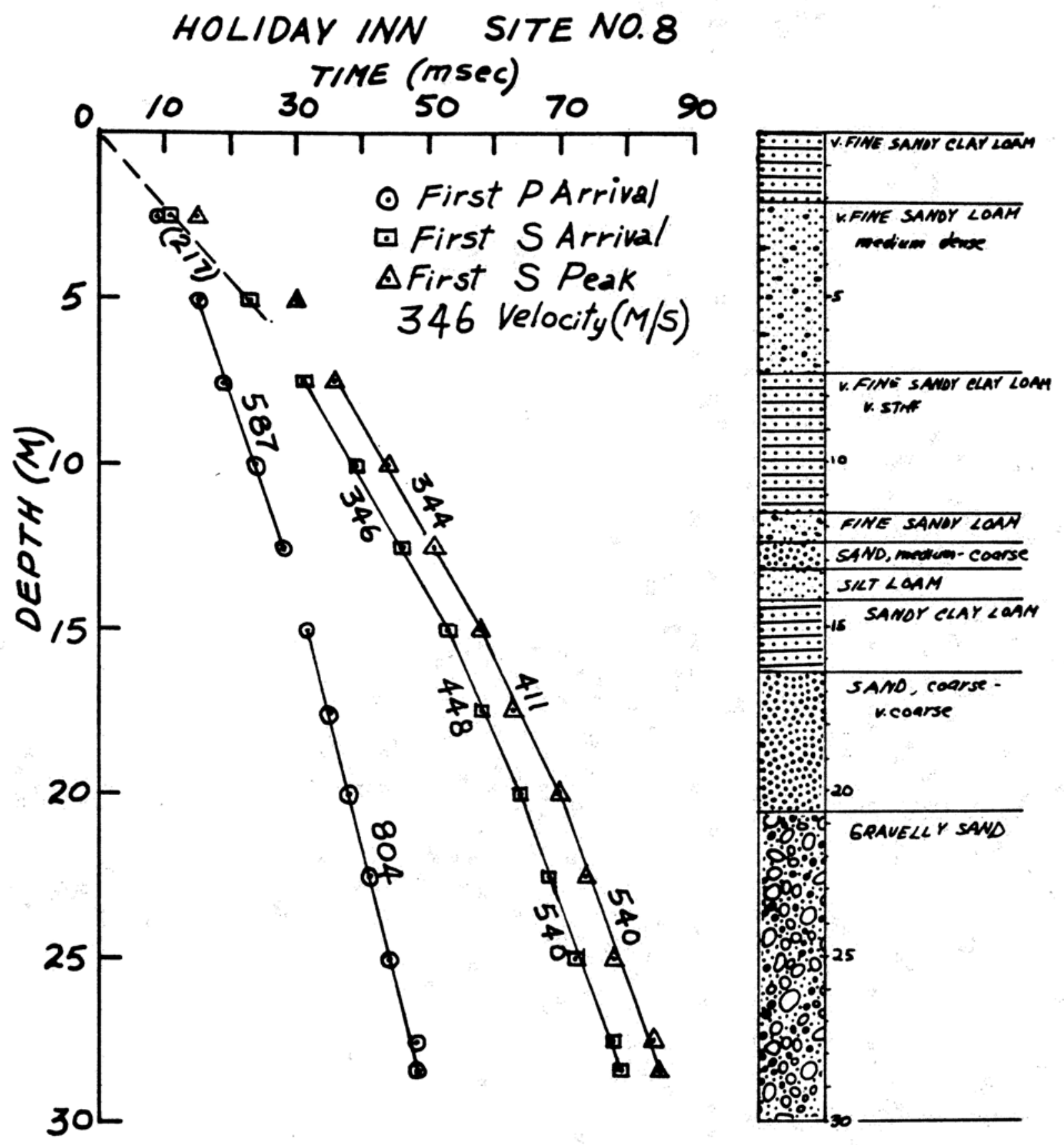

Figure 87. 


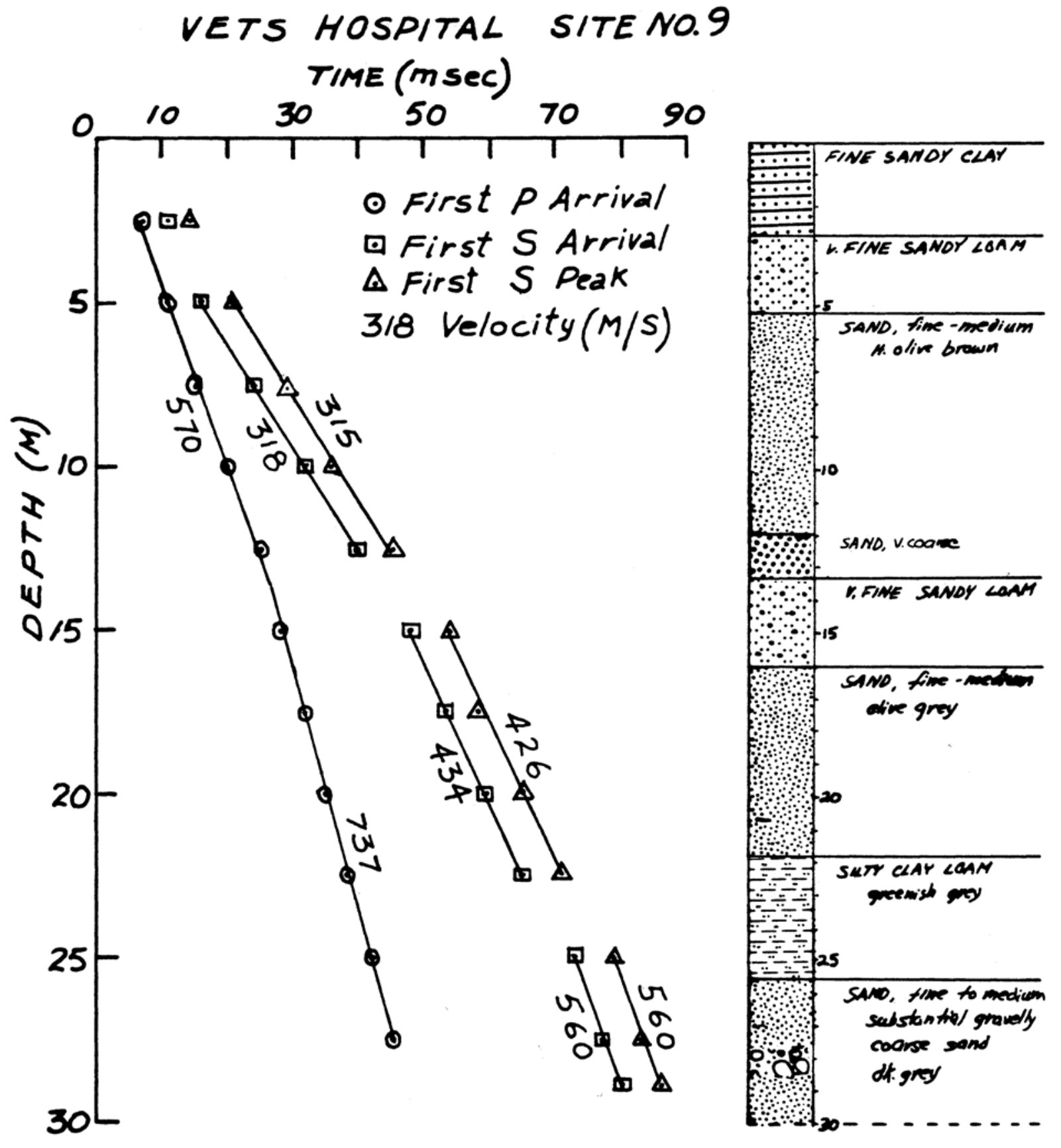

Figure 88. 


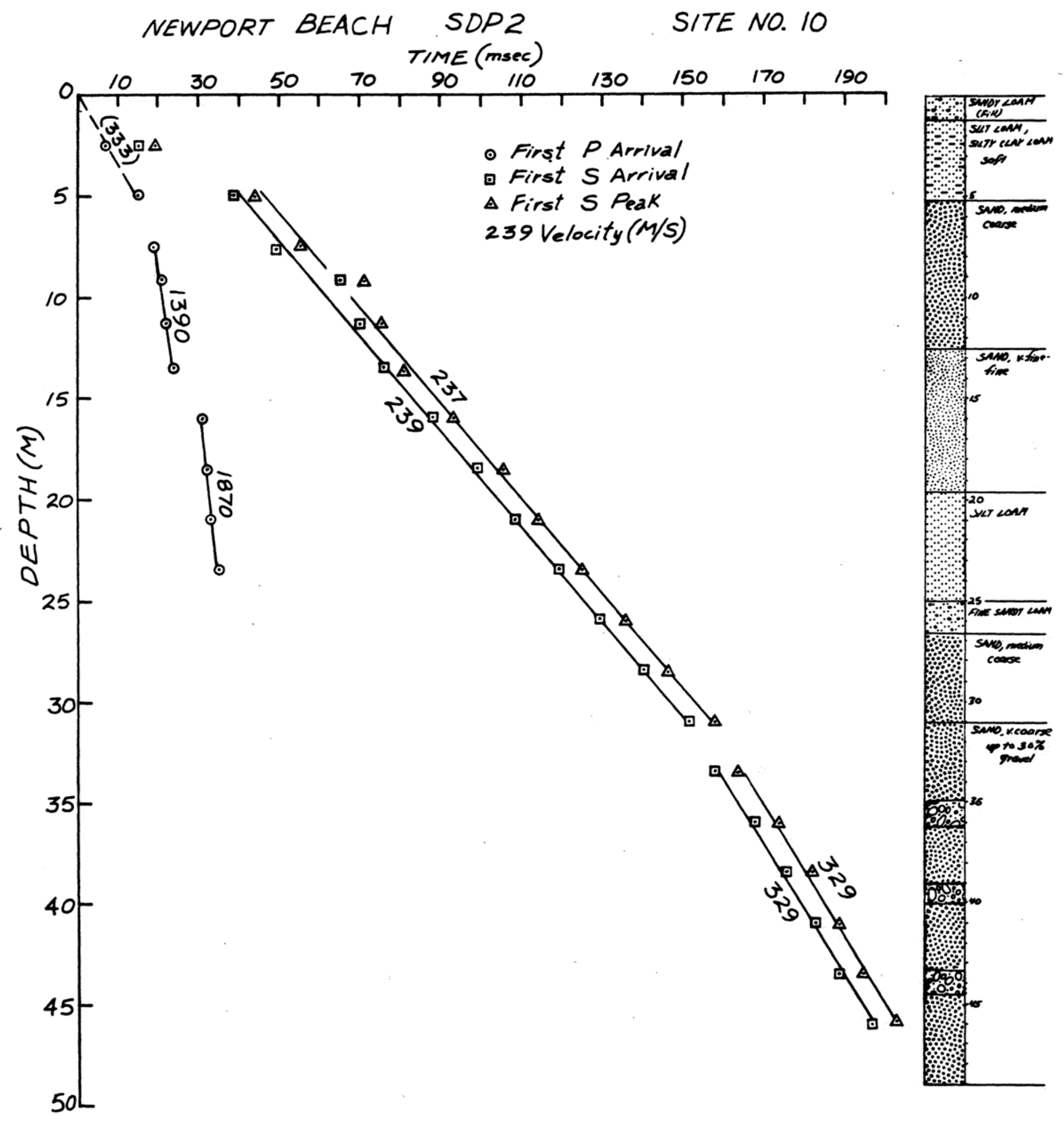

Figure 89. 


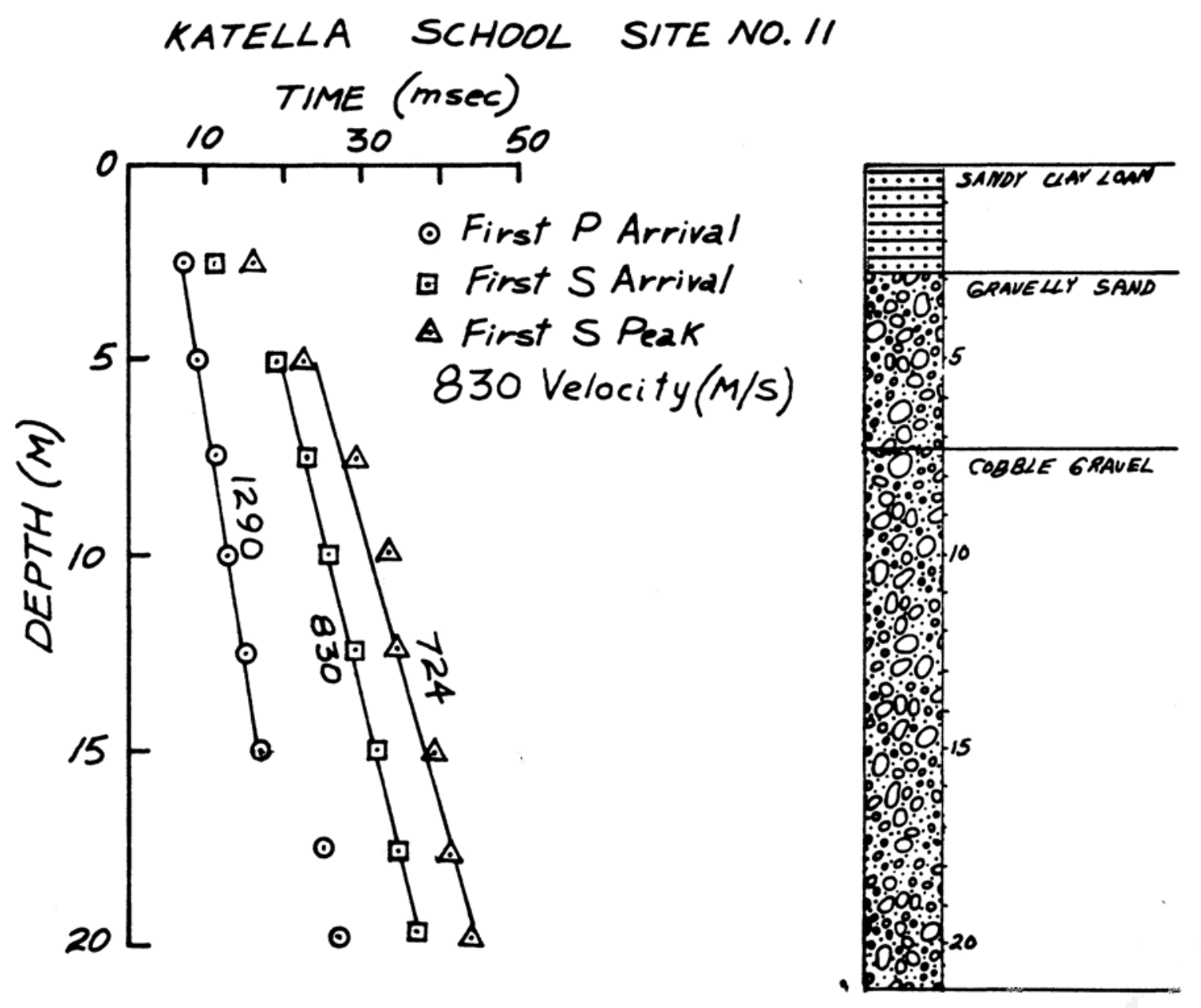

Figure 90. 
ST. JUDES HOSPITAL SITE NO. 12

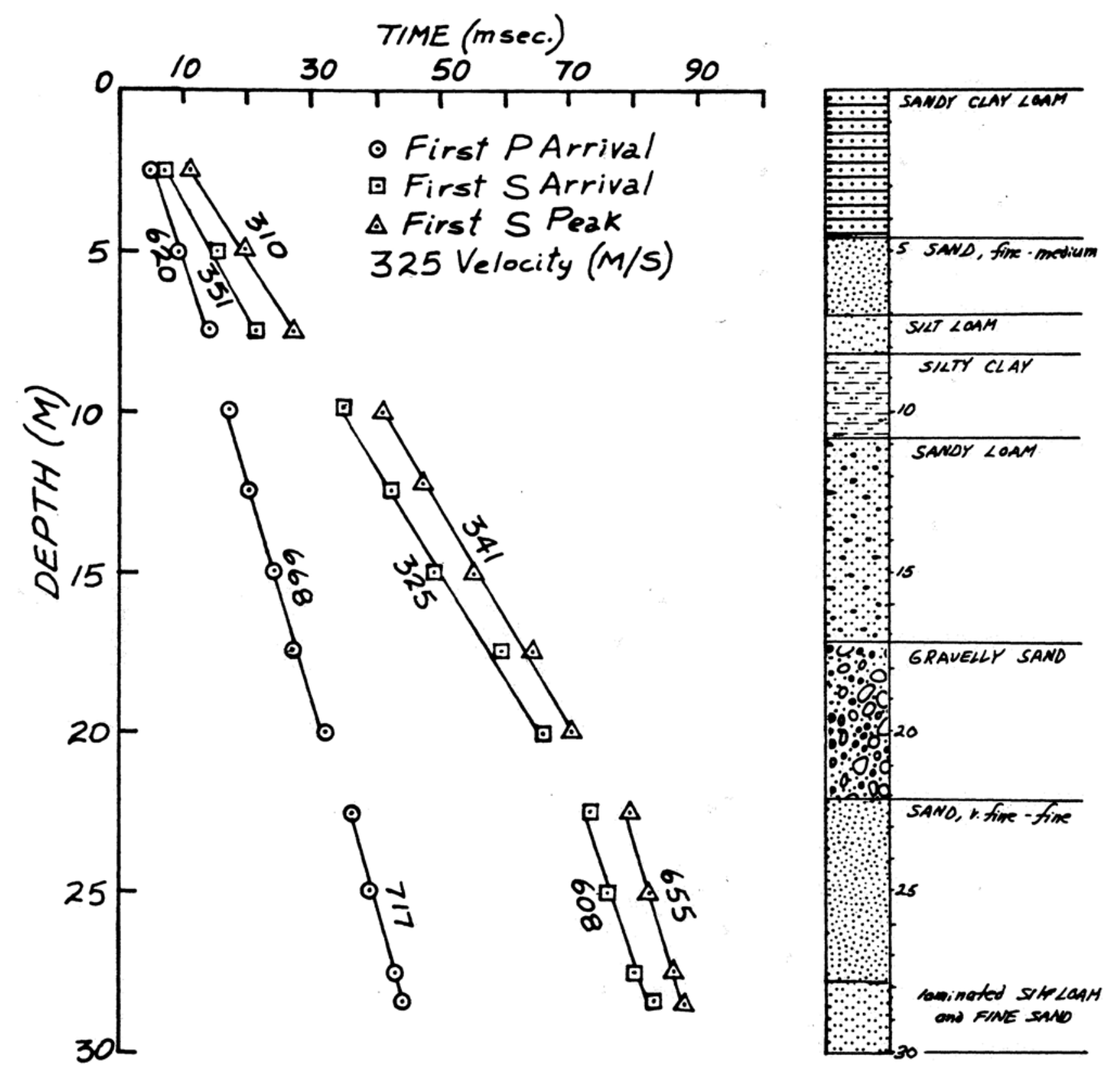

Figure 91. 


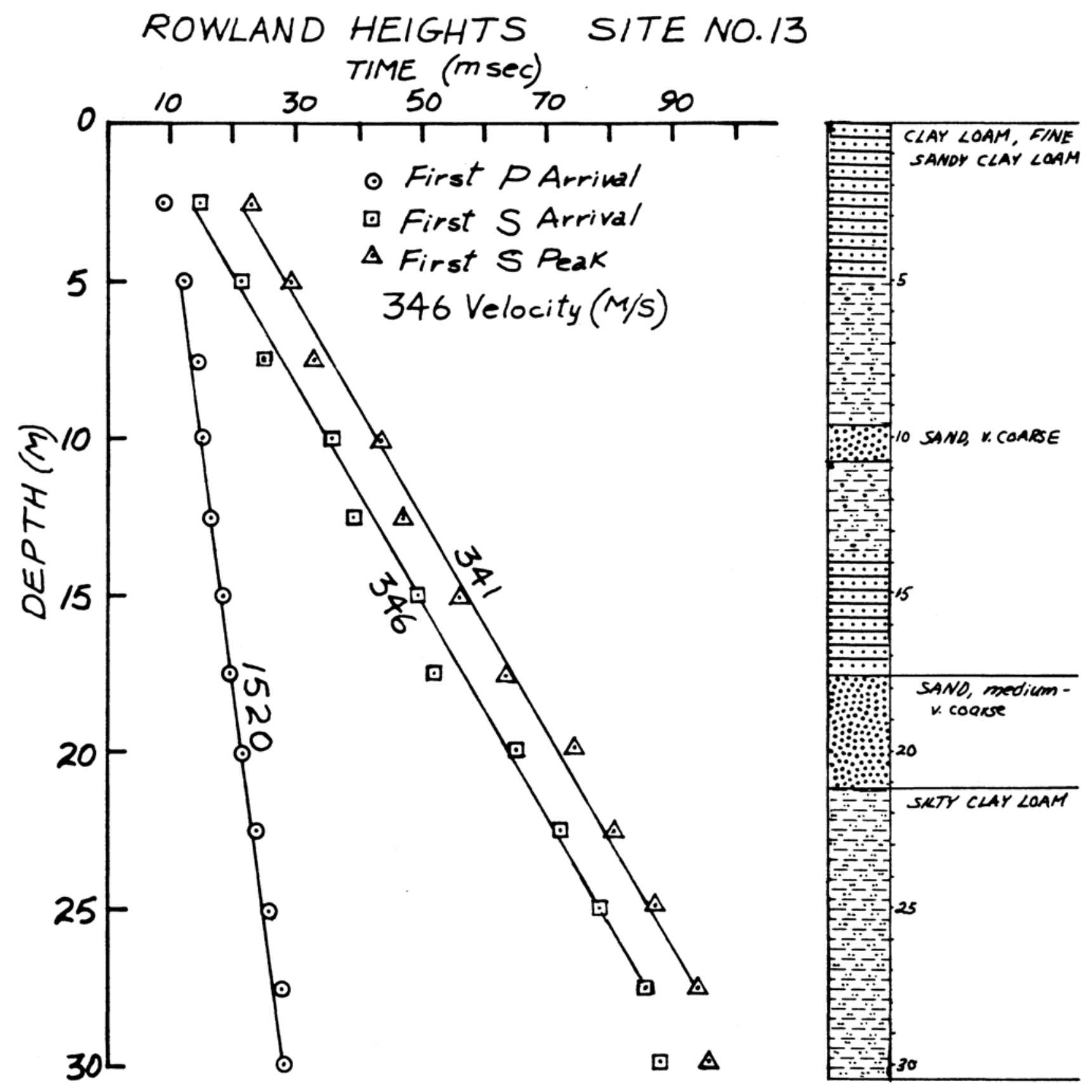

Figure 92. 


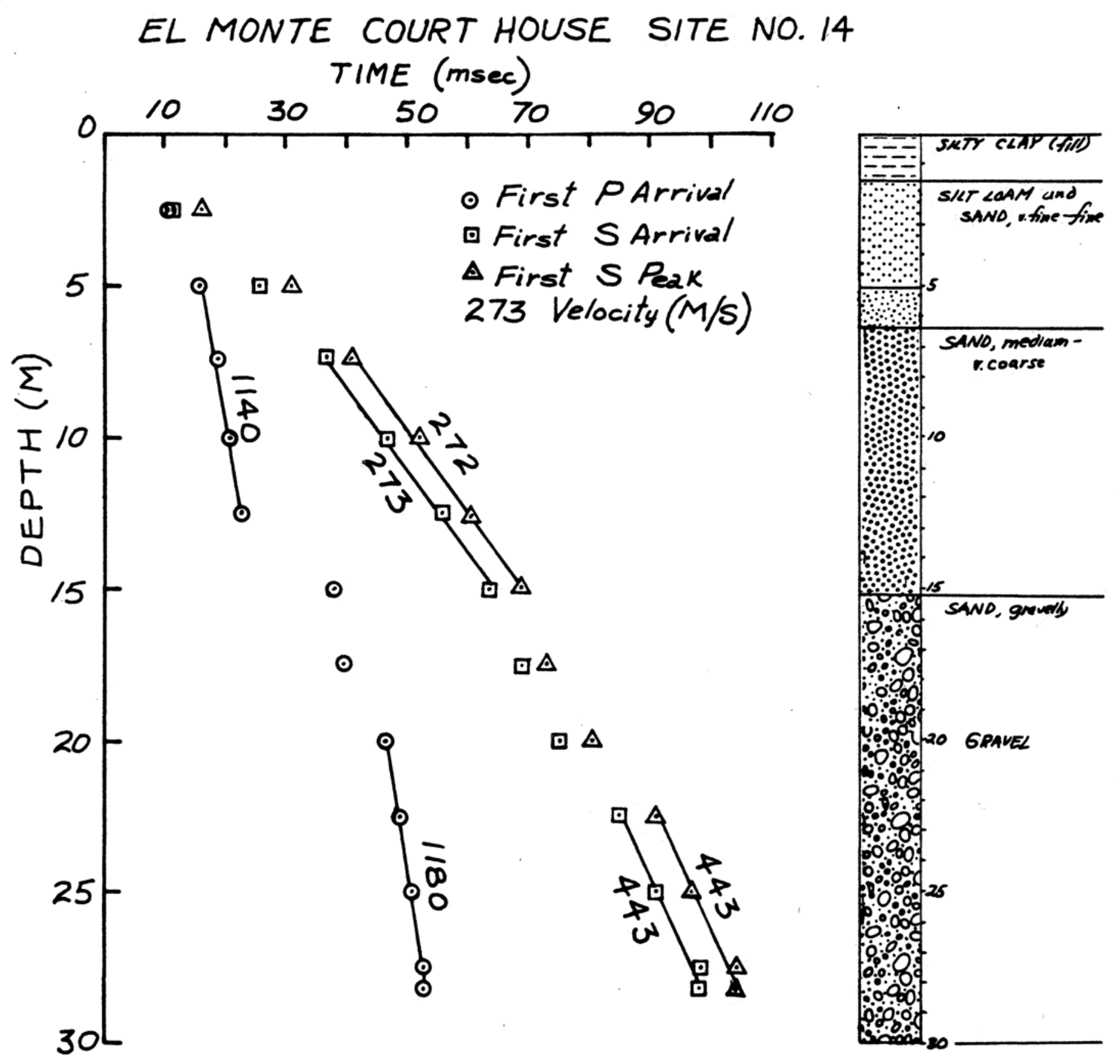

Figure 93. 


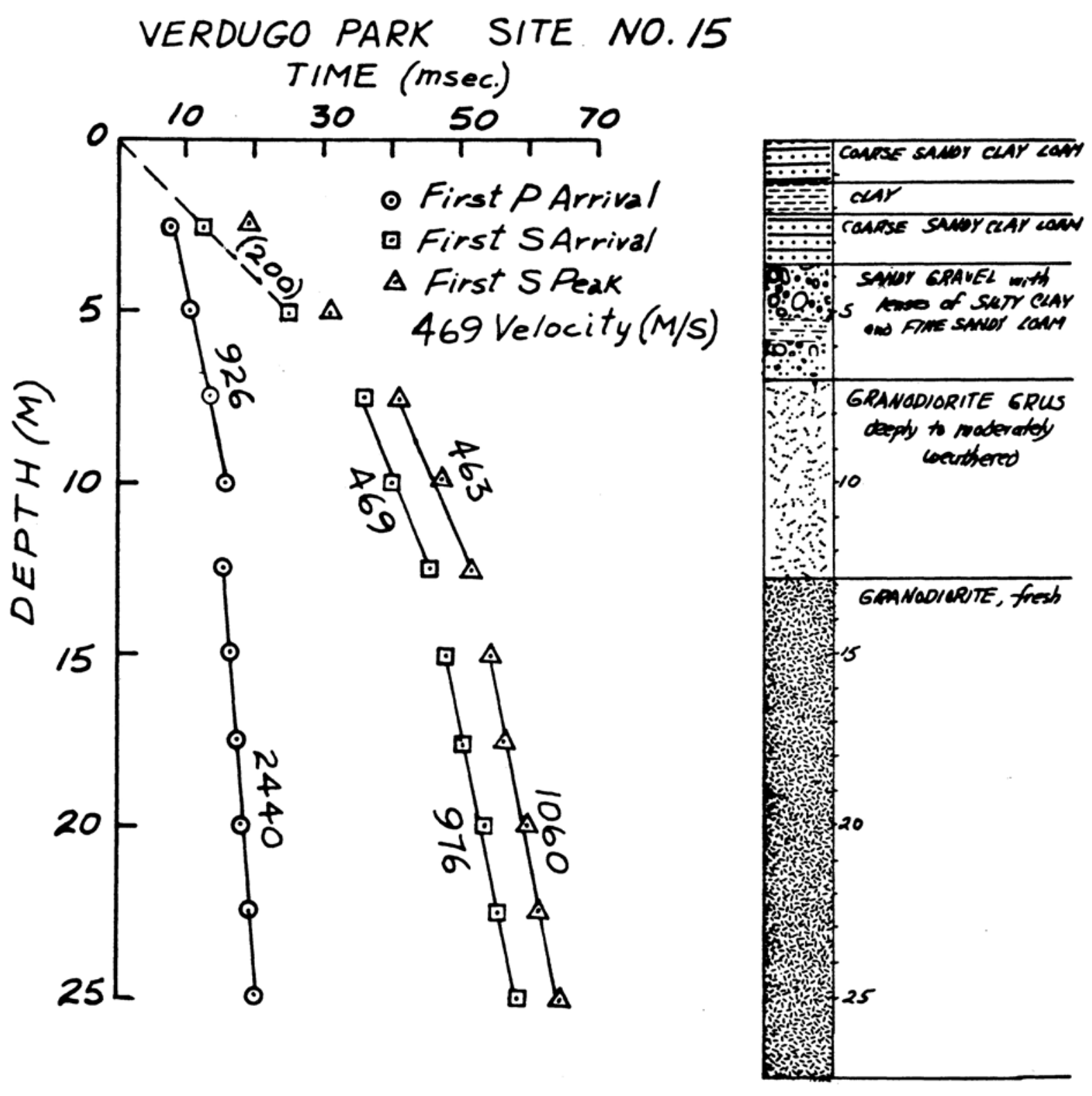

Figure 94. 


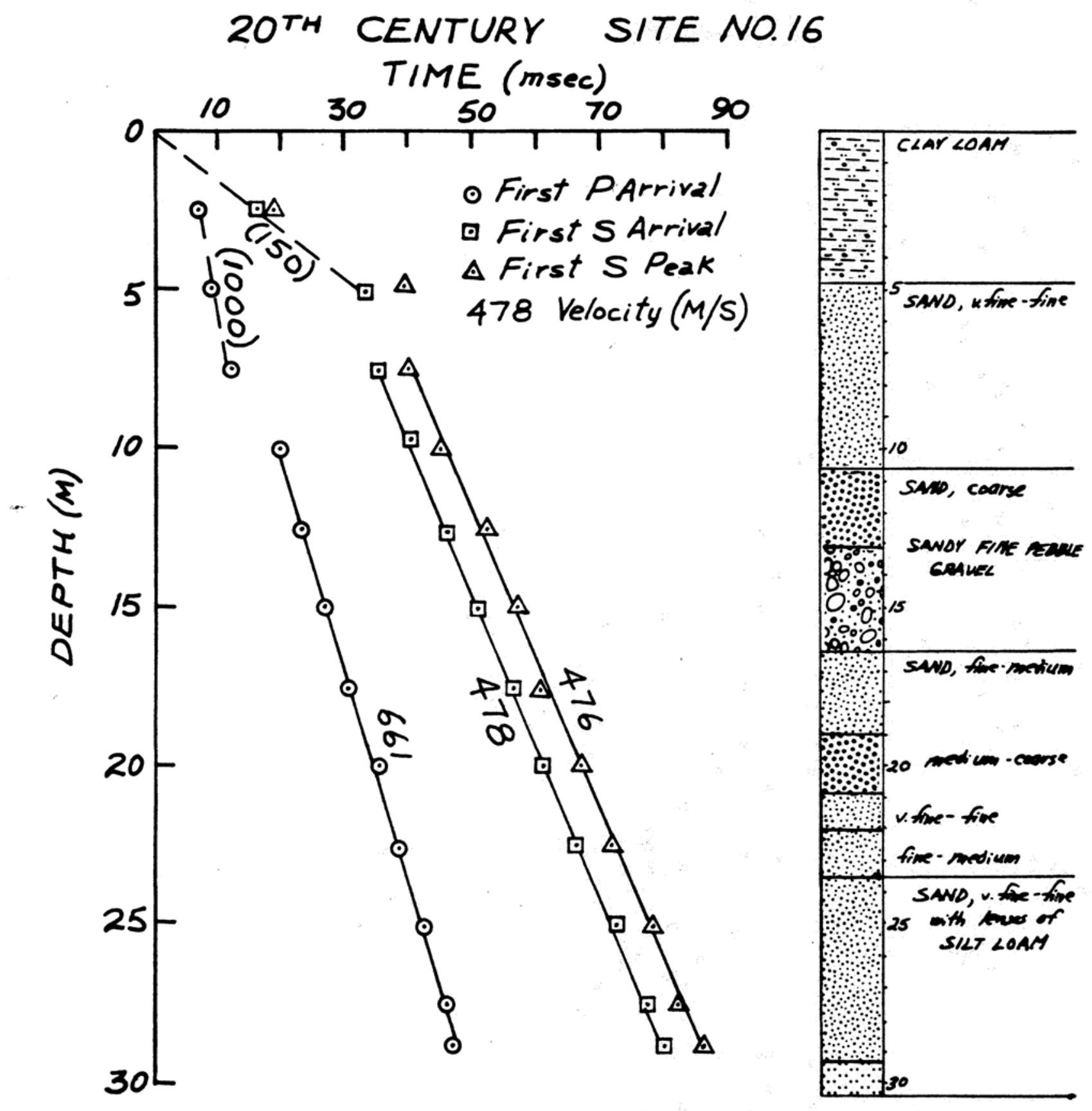

Figure 95. 


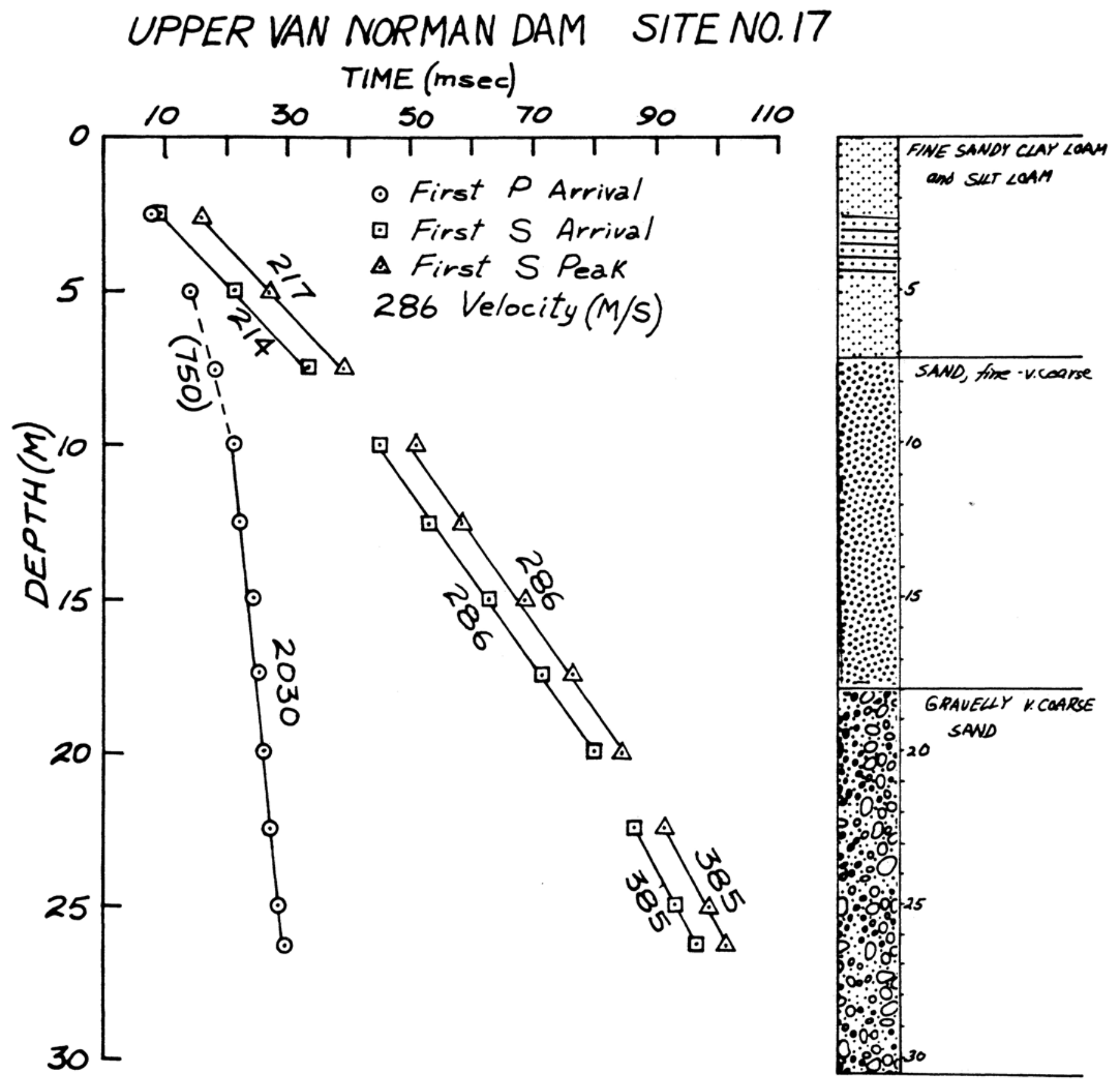

Figure 96. 
PACOIMA MEMORIAL hOSPITAL SITE NO. 18 TIME (msec)

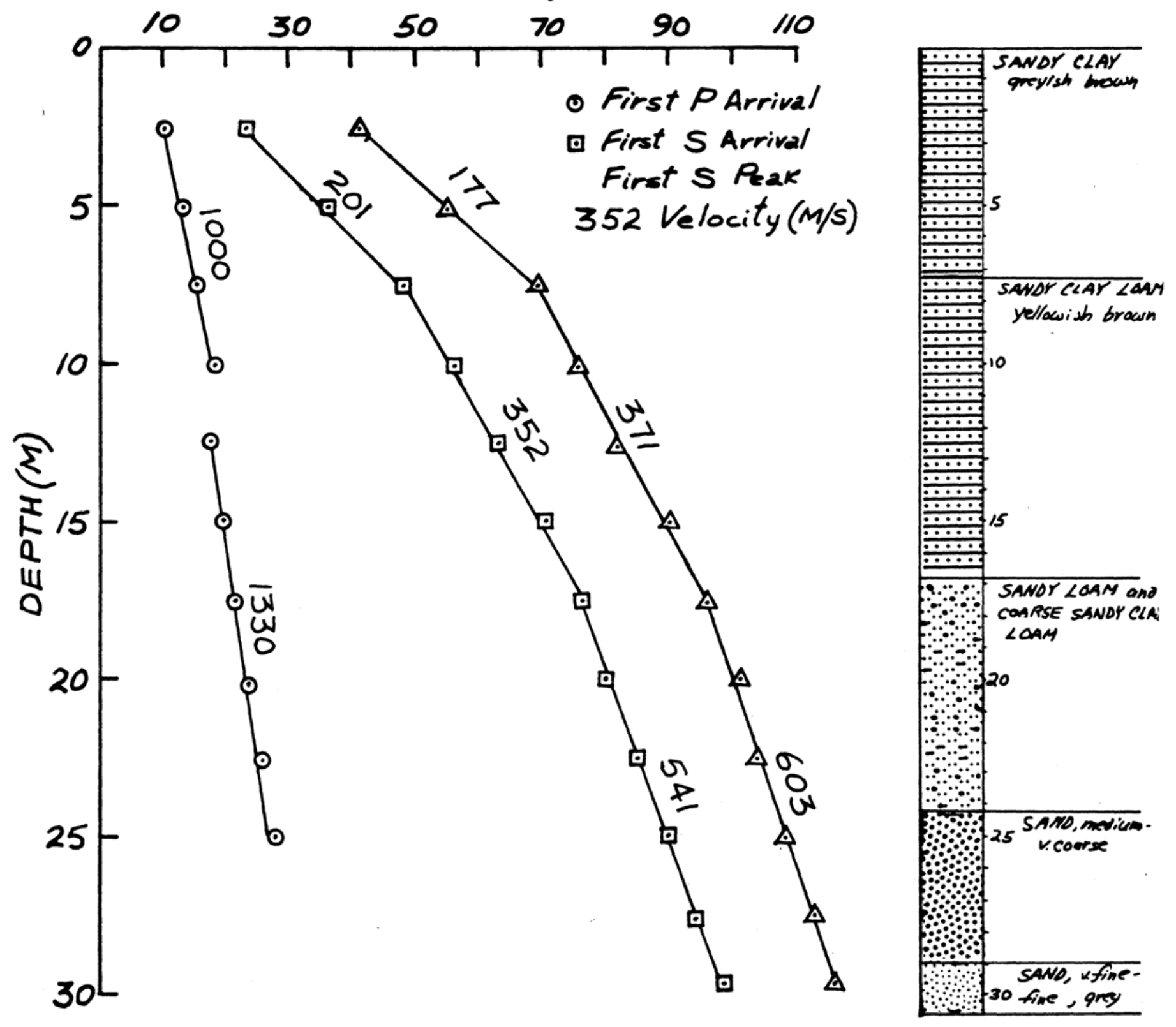

Figure 97. 


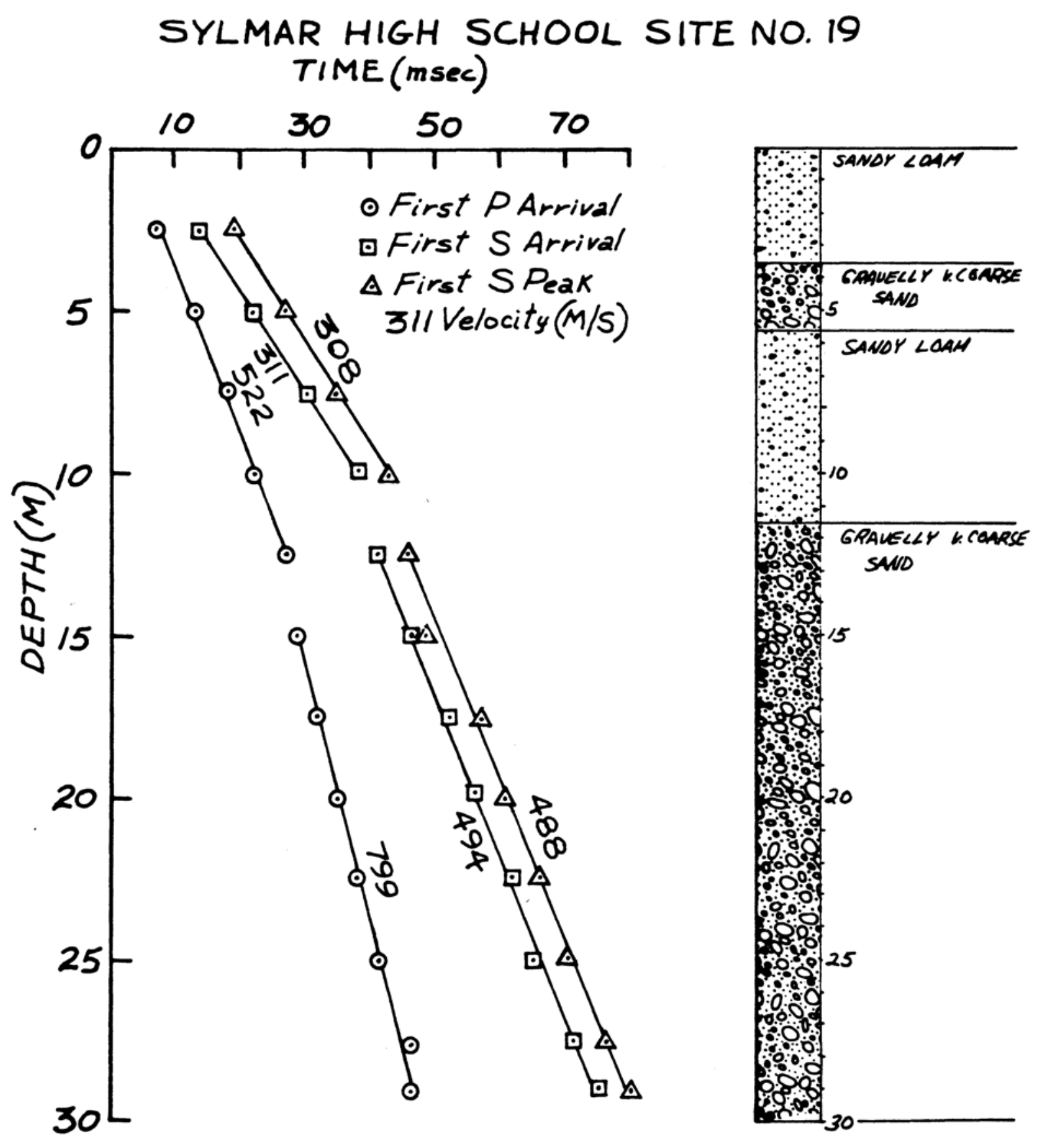

Figure 98. 


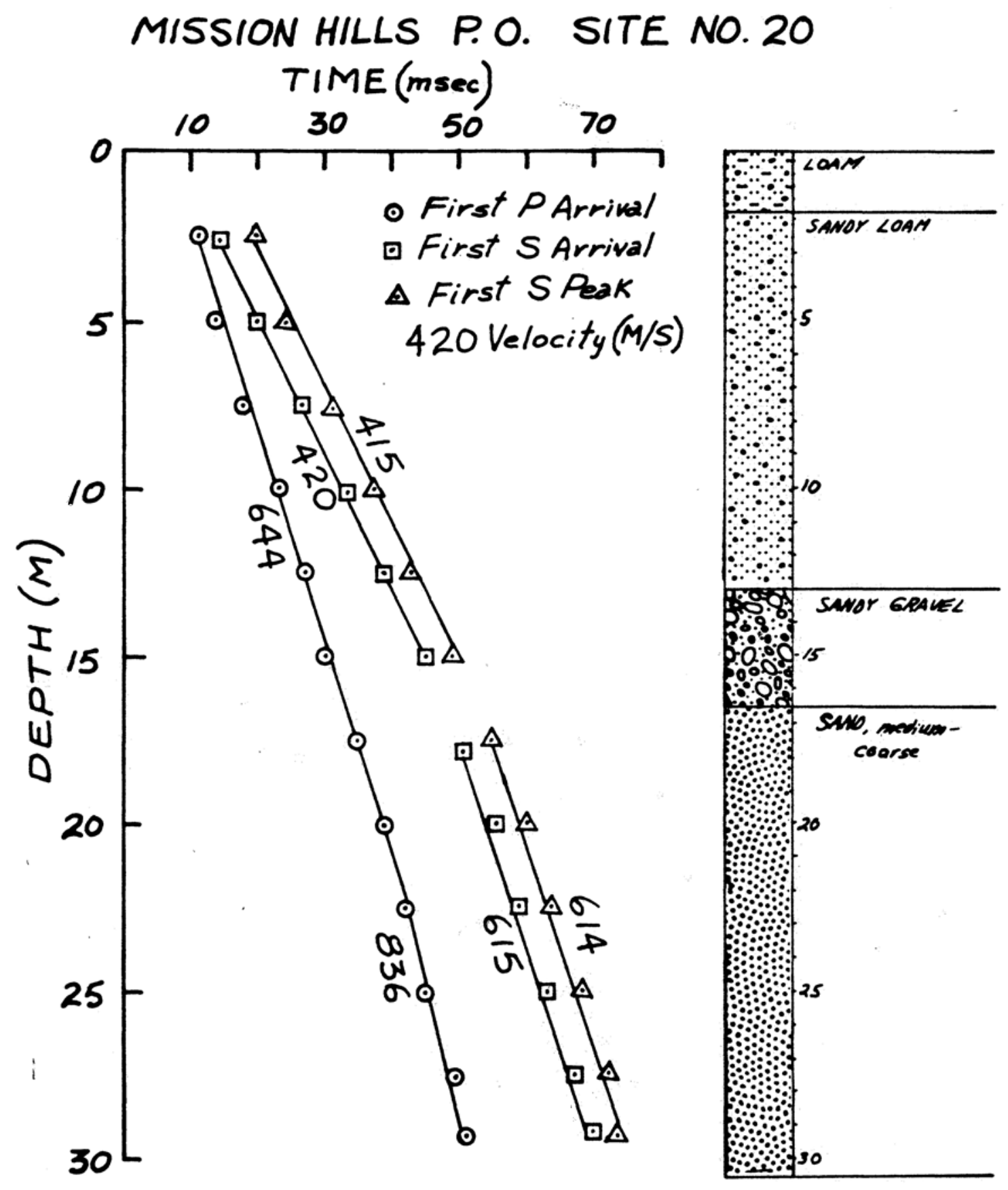

Figure 99. 


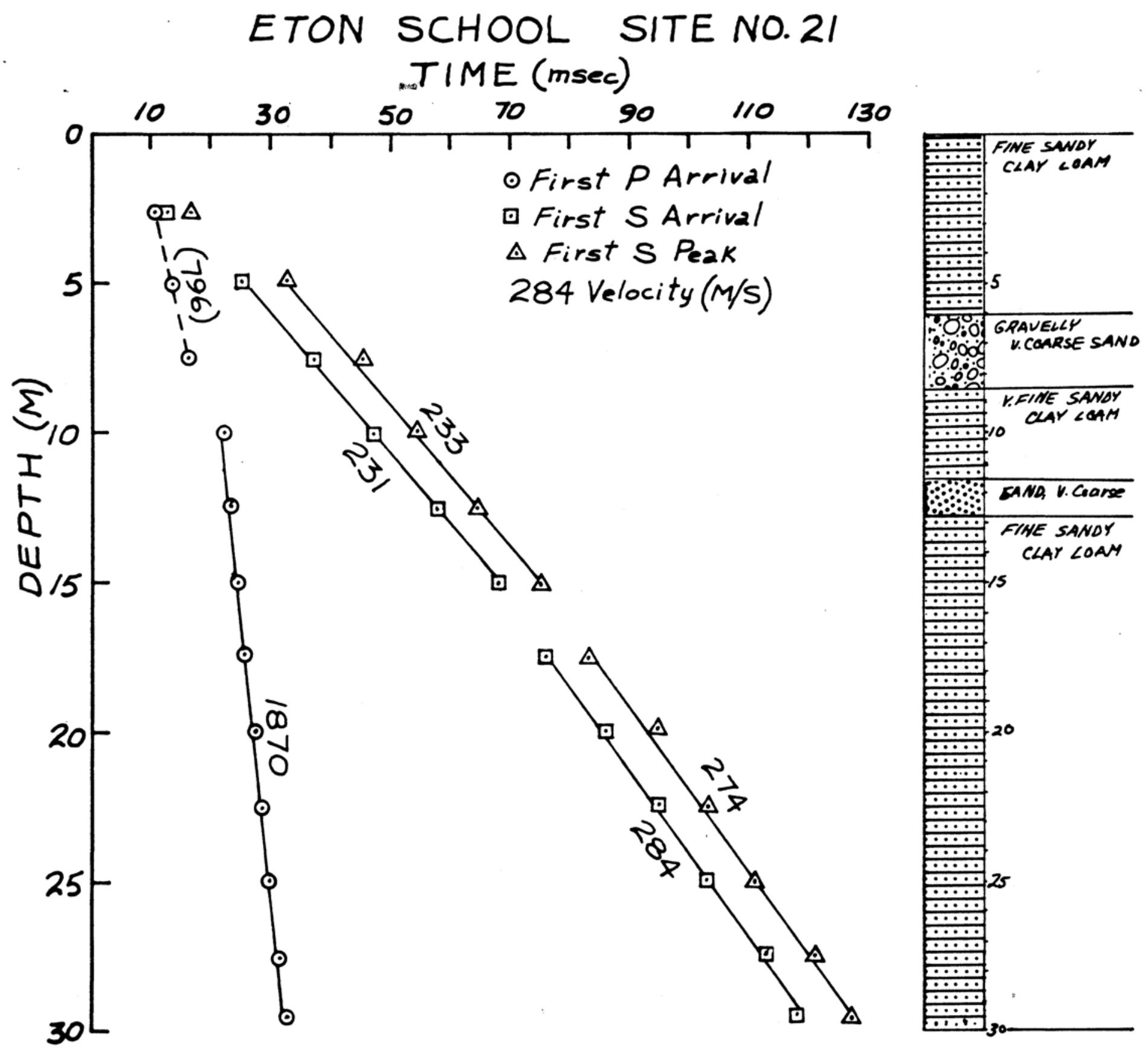

Figure 100. 


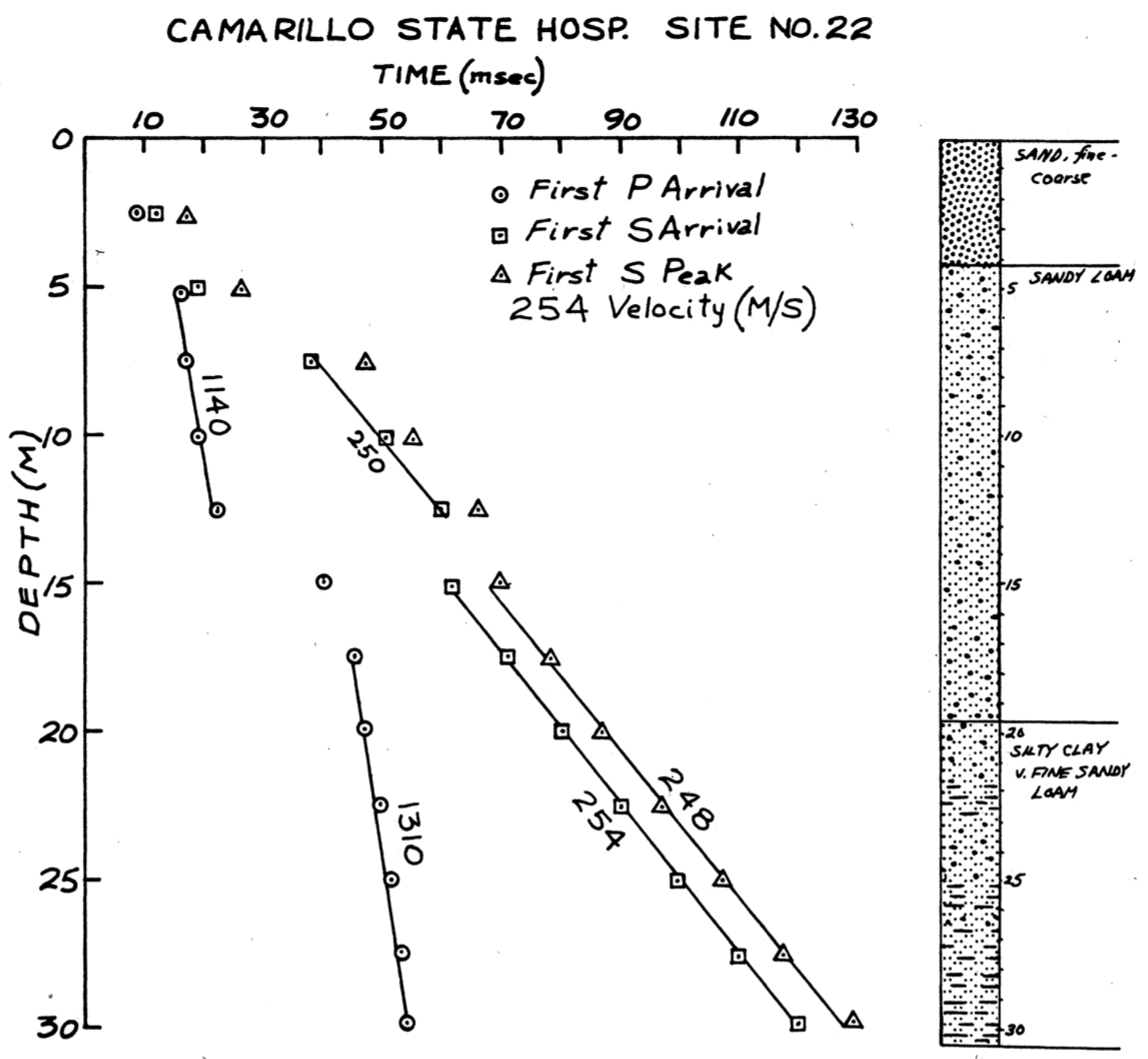

Figure 101. 


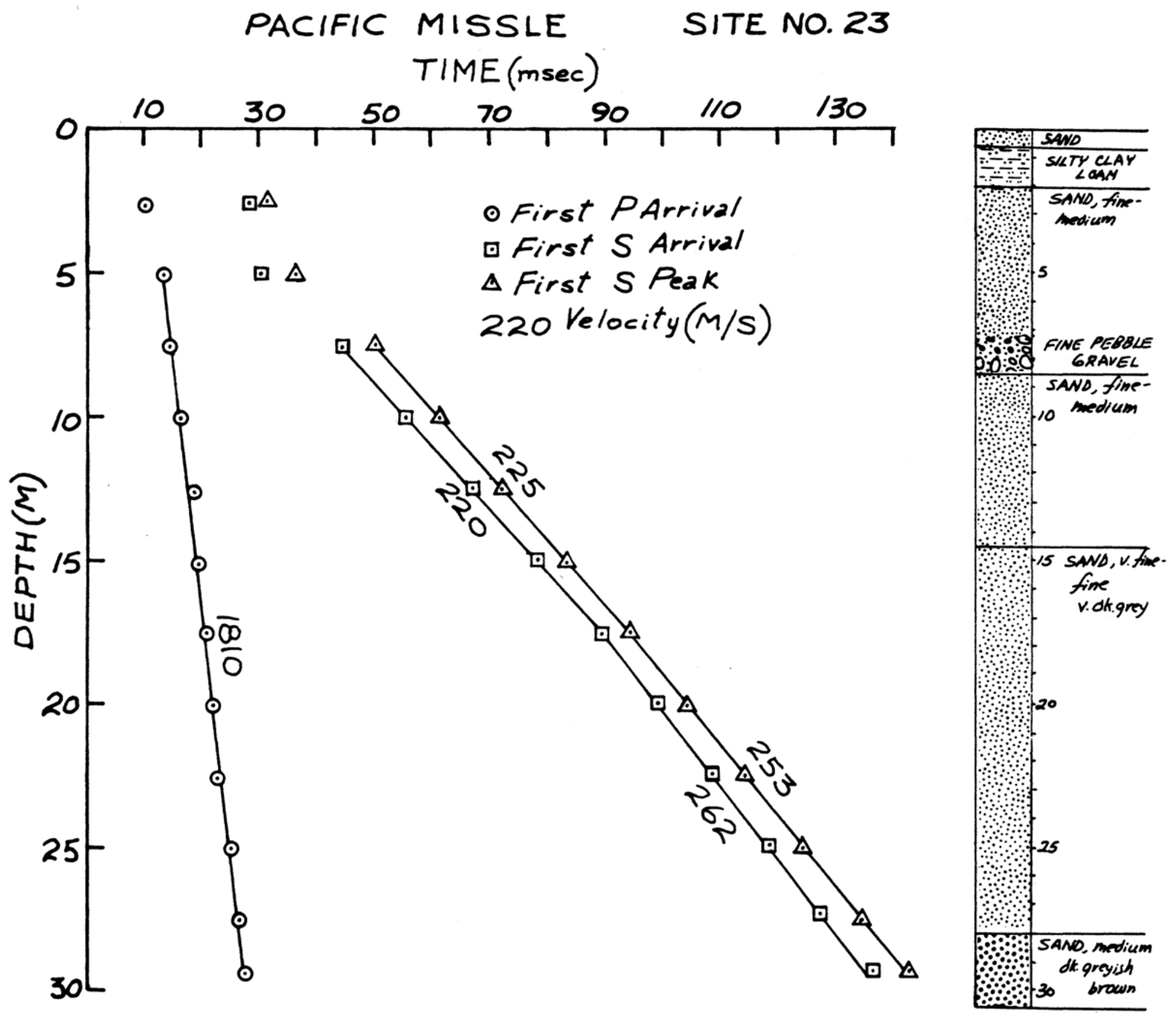

Figure 102. 


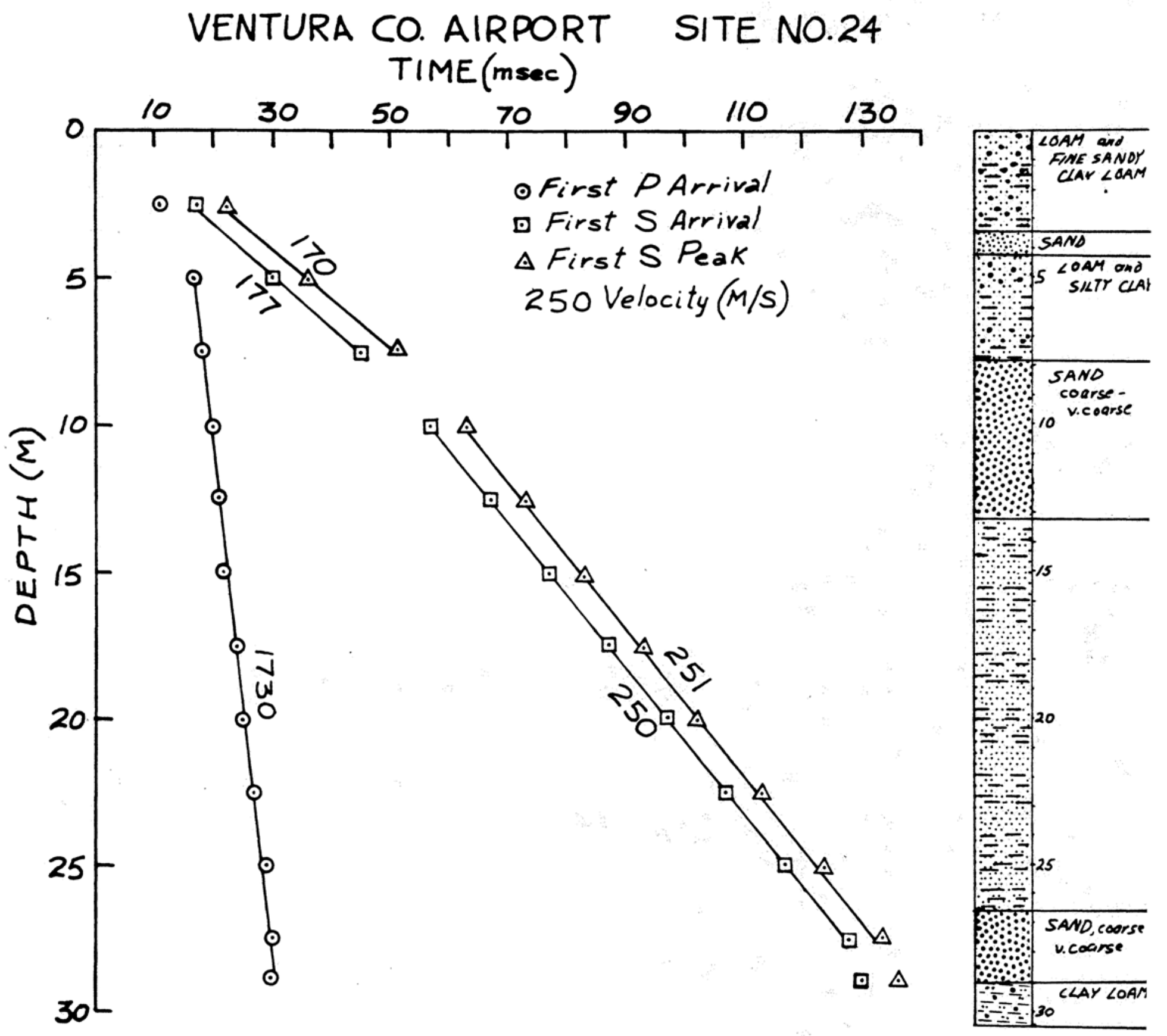

Figure 103. 


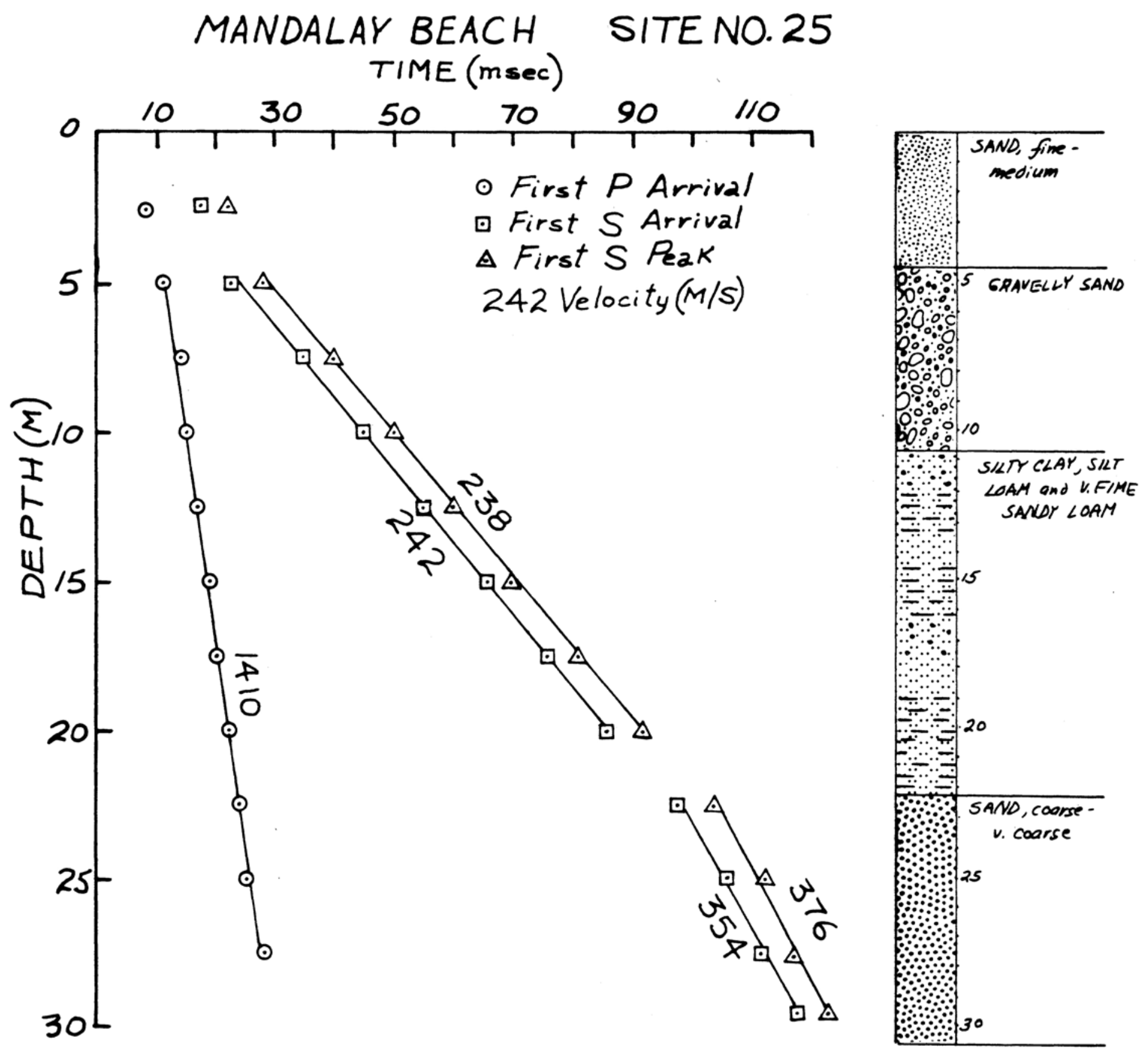

Figure 104. 


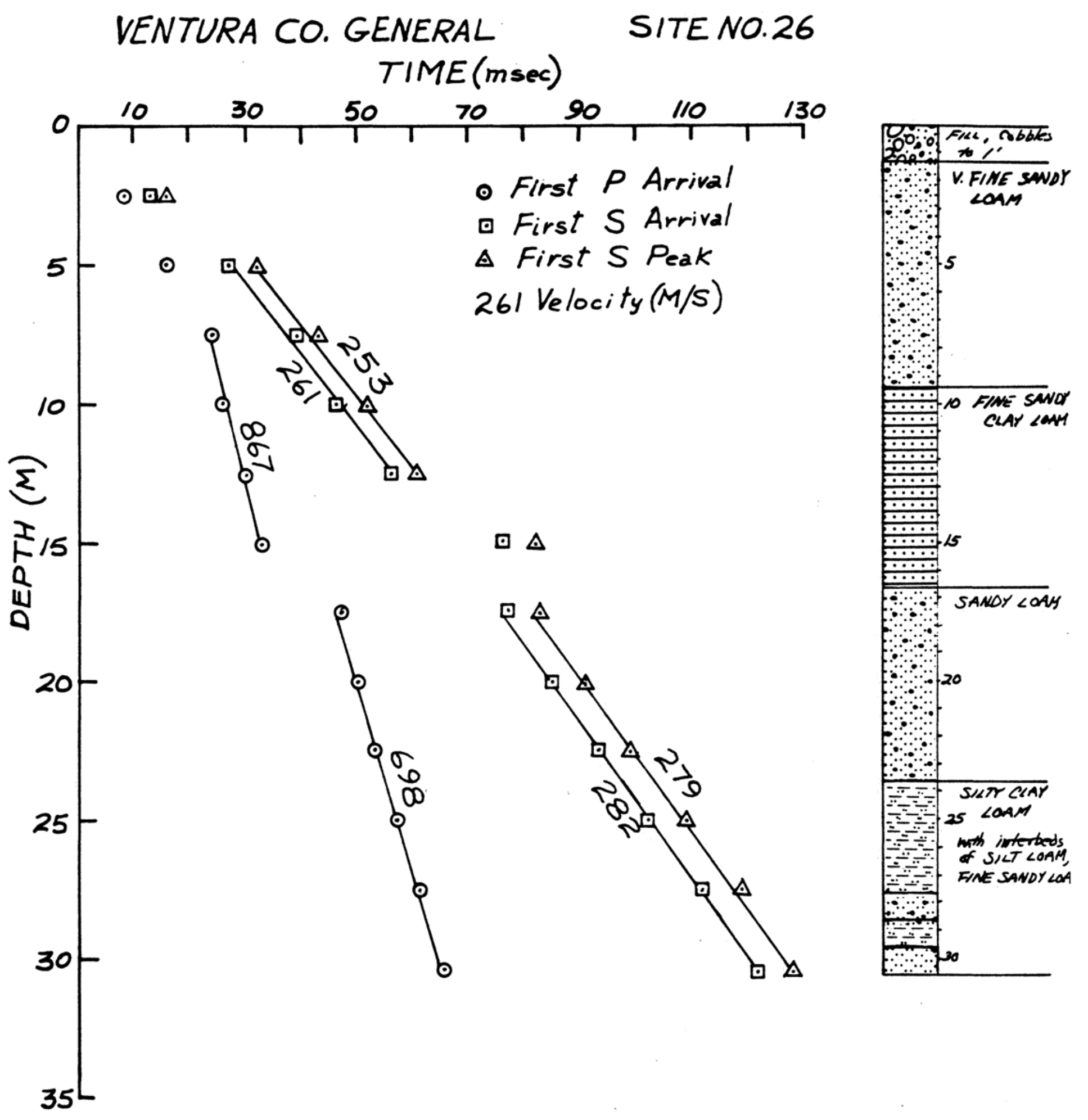

Figure 105. 


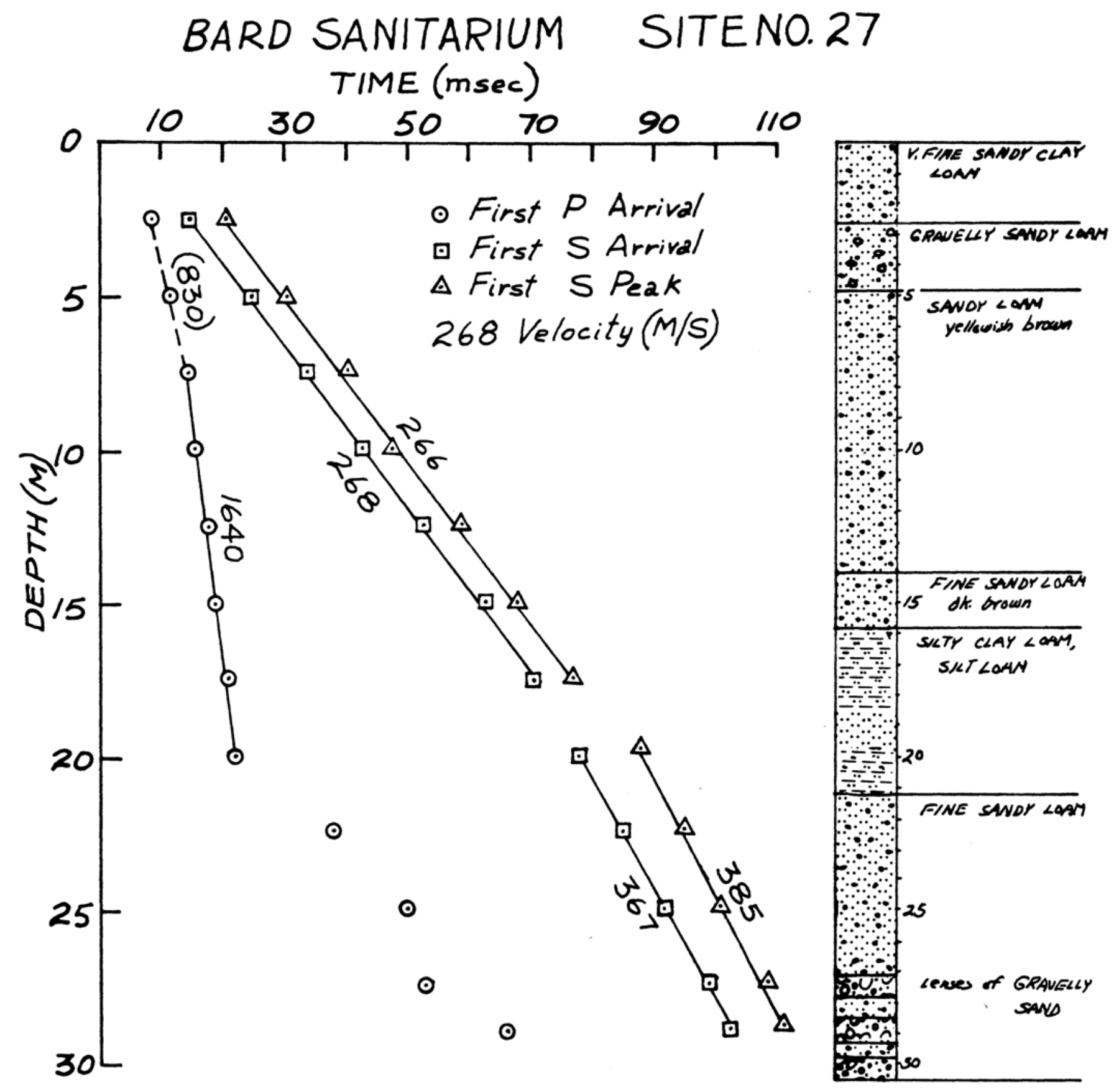

Figure 106. 
TABLE 1

TAÄVE-TIRES GN D AVERGGE VELOCITIES

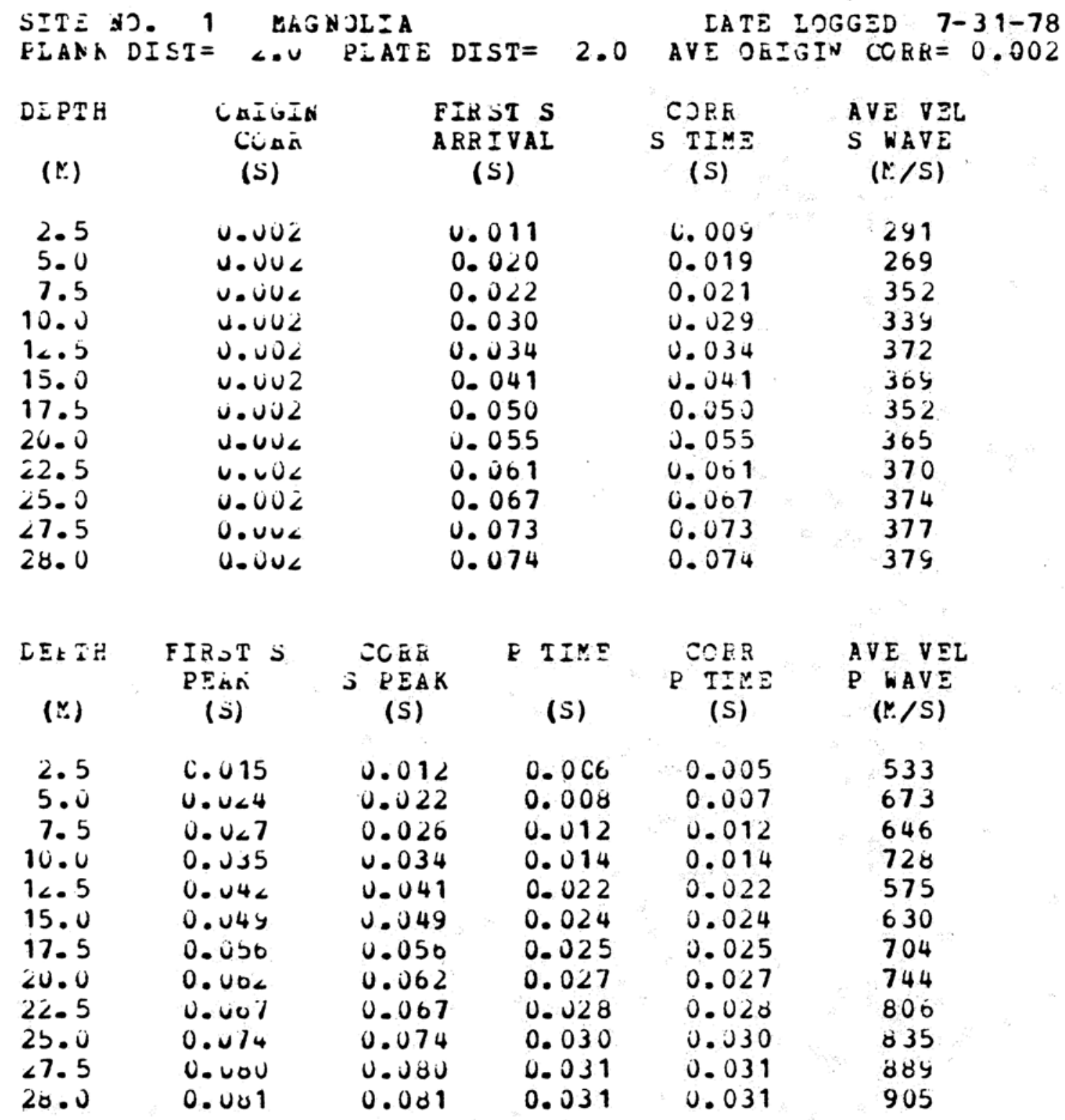




\section{TABLE 2}

TRAVEITTEES ABD AVERAGE VELCCITIES

\begin{tabular}{|c|c|c|c|c|c|}
\hline \multicolumn{2}{|c|}{$\begin{array}{l}\text { SIIE NOE } 2 \\
\text { KIANK DEST } \\
2 . J T\end{array}$} & \multicolumn{2}{|c|}{$\begin{array}{l}\text { ZUTHEKAN } \\
\text { PLATE DIST= }\end{array}$} & \multicolumn{2}{|c|}{$\begin{array}{l}\text { IATE LJGGED 8- } \\
\text { RVE OBIGIN CCRE= }\end{array}$} \\
\hline $\begin{array}{l}\text { CETTH } \\
\text { (M) }\end{array}$ & $\begin{array}{l}\text { ORIGIN } \\
\text { LOER } \\
\text { (S) }\end{array}$ & & $\begin{array}{l}\text { ST S } \\
\text { IVAI } \\
\text { S) }\end{array}$ & $\begin{array}{c}\text { CORR } \\
S \begin{array}{l}T Z M E \\
\text { (S) }\end{array}\end{array}$ & $\begin{array}{c}\text { AVE VEL } \\
S \text { WVE } \\
(N / S)\end{array}$ \\
\hline $\begin{array}{r}2.5 \\
5.0 \\
7.5 \\
10.0 \\
12.5 \\
15.0 \\
17.5 \\
20.0 \\
22.5 \\
25.0\end{array}$ & 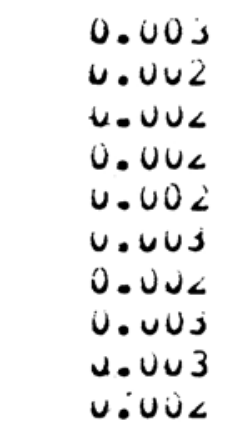 & & $\begin{array}{l}010 \\
018 \\
025 \\
032 \\
037 \\
042 \\
049 \\
056 \\
062 \\
068\end{array}$ & $\begin{array}{l}0.007 \\
0.016 \\
0.024 \\
0.031 \\
0.036 \\
0.041 \\
0.048 \\
0.055 \\
0.061 \\
0.067\end{array}$ & $\begin{array}{l}333 \\
305 \\
315 \\
322 \\
345 \\
363 \\
362 \\
361 \\
366 \\
371\end{array}$ \\
\hline $\begin{array}{c}\text { DEPTH } \\
(x)\end{array}$ & $\begin{array}{c}\text { FERSI S } \\
\text { PEAK } \\
\text { (১) }\end{array}$ & $\begin{array}{c}C O A R \\
S \quad P \Xi A K \\
\text { (S) }\end{array}$ & $\begin{array}{c}P T I N E \\
\text { (S) }\end{array}$ & $\begin{array}{c}\text { CORR } \\
\text { P IIME } \\
(S)\end{array}$ & $\begin{array}{l}\text { AVE VEL } \\
\text { P WAVE } \\
(Y / S)\end{array}$ \\
\hline $\begin{array}{l}2.5 \\
5.0 \\
7.5 \\
10.0 \\
12.5 \\
15.0 \\
17.5 \\
20.0 \\
22.5 \\
25.0\end{array}$ & $\begin{array}{l}0.414 \\
0.0<2 \\
0.031 \\
0.030 \\
0.045 \\
0 . \cup 40 \\
0.055 \\
0.002 \\
0.000 \\
0.074\end{array}$ & $\begin{array}{l}0.011 \\
0.020 \\
0.050 \\
0.037 \\
0.044 \\
0.047 \\
0.054 \\
0.061 \\
0.067 \\
0.073\end{array}$ & $\begin{array}{l}0.006 \\
0.008 \\
0.010 \\
0.014 \\
0.023 \\
0.024 \\
0.026 \\
0.027 \\
0.029 \\
0.031\end{array}$ & $\begin{array}{l}0.005 \\
0.007 \\
0.010 \\
0.014 \\
0.023 \\
0.024 \\
0.026 \\
0.027 \\
0.029 \\
0.031\end{array}$ & $\begin{array}{l}533 \\
673 \\
776 \\
728 \\
550 \\
630 \\
677 \\
744 \\
770 \\
809\end{array}$ \\
\hline
\end{tabular}


TABLE 3

TEATEL-TIMES AND AVERAGE VELOCITEES

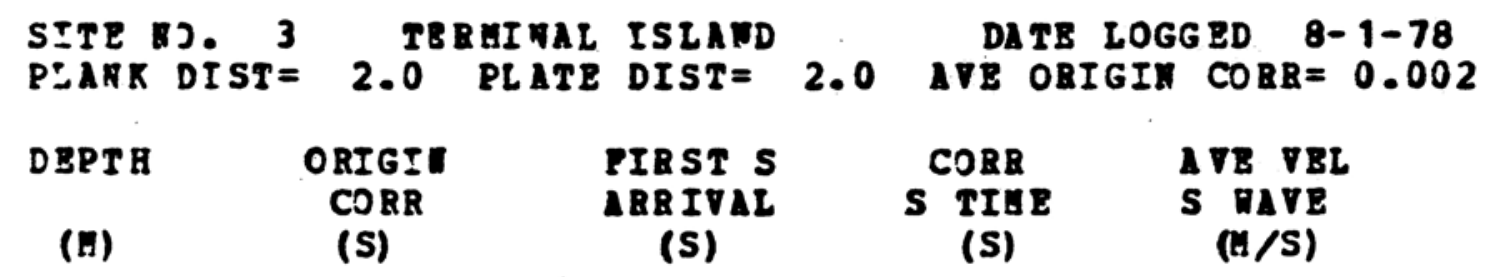

$\begin{array}{rr}2.5 & 0.002 \\ 5.0 & 0.002 \\ 7.5 & 0.003 \\ 10.0 & 0.003 \\ 12.5 & 0.002 \\ 15.0 & 0.002 \\ 17.5 & 0.002 \\ 19.5 & 0.001\end{array}$

0.021

0.034

0.046

0.057

0.066

0.078

0.087

0.095

0.016

0.031

0.044

0.056

0.065

0.077

0.086

0.094

P TIME

(S)

CORR
P TIHE

(S)

0.014

0.016

0.017

0.018

0.020

0.021

0.022

0.023
0.011

0.015

0.016

0.018

0.020

0.021

0.022

0.023
153

158

169

179

192

194

202

206

17.5

0.091

0.090

0.098

0.099

0.023
ATE VEL
$P$ RAVB
( $1 / \mathrm{S})$

228

336

456

566

632

720

800

852 
TABLE 4

TEAVEI-TINES AA A AVERAGE VELOCITIES

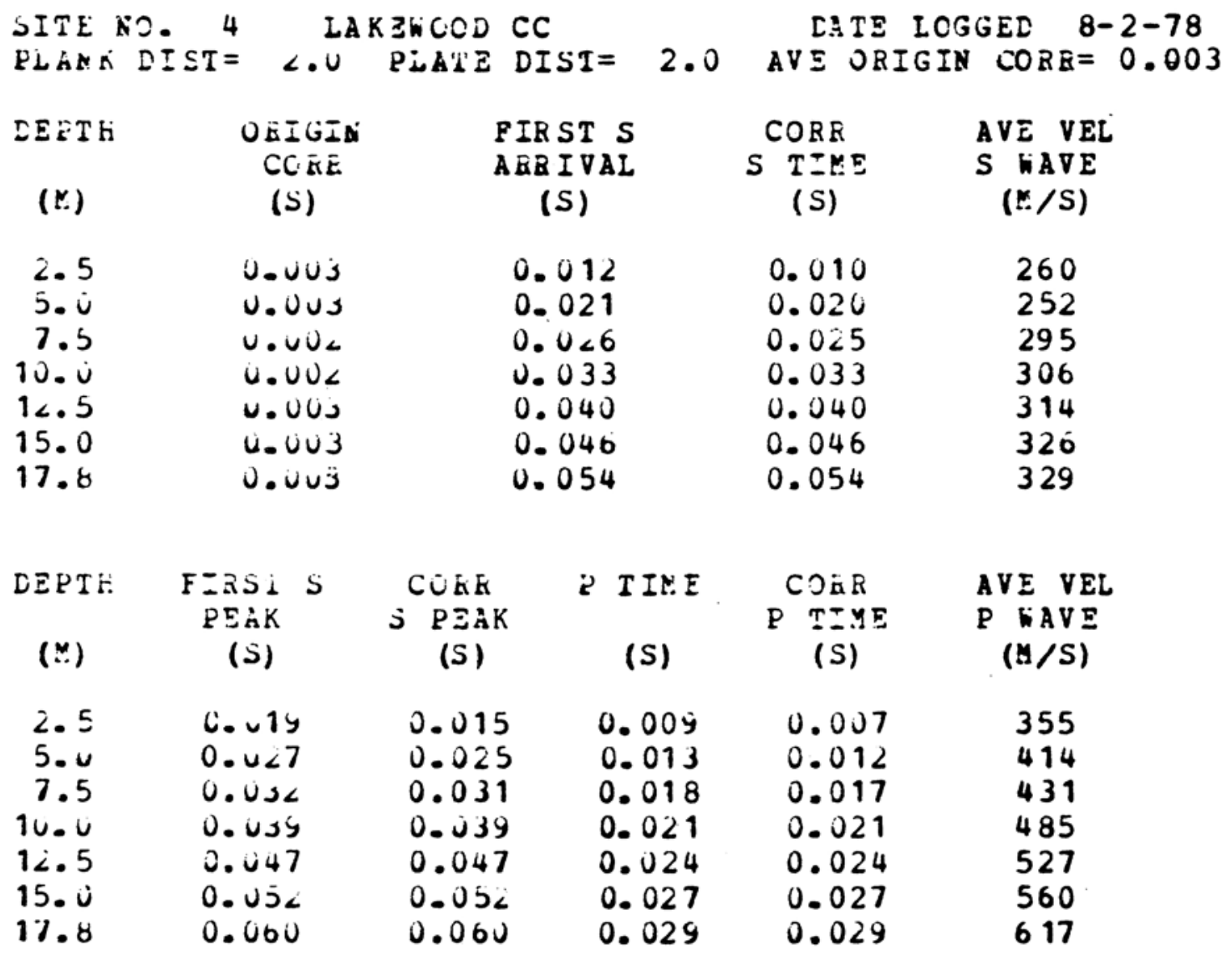


TABLE 5

TRAVEI-ITMES AND AVERAGE VELOCITIES

\begin{tabular}{|c|c|c|c|c|}
\hline $\begin{array}{l}\text { SITE J. } 5 \\
\text { PLANR DIST= }\end{array}$ & 2.0 & $\begin{array}{l}105 \\
\text { PLATE DIST }=\end{array}$ & 2.0 & $\begin{array}{c}\text { DATE LOGG ED } \quad 8-2-78 \\
\text { AVB ORIGIA CDBR }=0.002\end{array}$ \\
\hline $\begin{array}{c}\text { DEPTH } \\
\text { (H) }\end{array}$ & $\begin{array}{l}\text { ORIGIY } \\
\text { CORR } \\
\text { (S) }\end{array}$ & $\begin{array}{l}\text { PIRST S } \\
\text { ARRIVAL } \\
\text { (S) }\end{array}$ & & $\begin{array}{c}A V E \text { VBL } \\
S \text { AVE } \\
(B / S)\end{array}$ \\
\hline
\end{tabular}

$\begin{array}{rr}2.5 & 0.002 \\ 5.0 & 0.002 \\ 7.5 & 0.002 \\ 10.0 & 0.002 \\ 12.5 & 0.002 \\ 15.0 & 0.002 \\ 17.5 & 0.002 \\ 20.0 & 0.002 \\ 22.5 & 0.002 \\ 25.0 & 0.002 \\ 27.5 & 0.002 \\ 27.8 & 0.002\end{array}$

0.021

0.033

0.045

0.055

0.065

0.074

0.081

0.090

0.098

0.106

0.114

0.115
0.016

0.031

0.043

0.054

0.064

0.073

0.080

0.090

0.098

0.106

0.114

0.115

P TIME

(S)

(S)

0.022
0.037
0.049
0.061
0.070
0.079
0.087
0.096
0.104
0.112
0.121
0.122
0.014

0.020

0.024

0.028

0.032

0.037

0.042

0.047

0.050

0.053

0.055

0.056
CORB
P TIYE
(S)

0.011

0.019

0.023

0.027

0.032

0.037

0.042

0.047

0.050

0.053

0.055

0.056
152

163

172

185

194

204

217

223

230

236

241

242

27.8

0.122

A VE $\nabla B L$
DAVB
$(\mathrm{H} / \mathrm{S})$

228

269

323

364

395

408

419

427

451

473

501

497 
TABLE 6

\section{TRAVEL-TIMES ARD AVERAGE VELOCITIES}

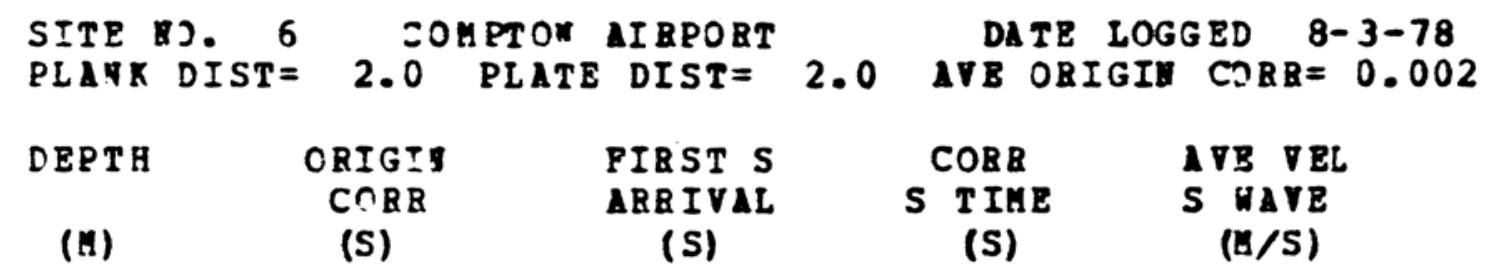

$\begin{array}{rr}2.5 & 0.003 \\ 5.0 & 0.003 \\ 7.5 & 0.003 \\ 10.0 & 0.002 \\ 12.5 & 0.002 \\ 15.0 & 0.002 \\ 17.5 & 0.002\end{array}$

$$
\begin{aligned}
& 0.013 \\
& 0.021 \\
& 0.030 \\
& 0.044 \\
& 0.047 \\
& 0.056 \\
& 0.059
\end{aligned}
$$

0.010

254

$0.019 \quad 261$

0.029

0.043

0.046

0.055

\begin{tabular}{|c|c|c|c|c|c|}
\hline $\begin{array}{l}\text { CZPTH } \\
\text { (A) }\end{array}$ & $\begin{array}{c}\text { PIRST } \\
\text { PEAR } \\
\text { (S) }\end{array}$ & $\begin{array}{l}\text { CJRB } \\
S \stackrel{\text { PEAK }}{\text { (S) }}\end{array}$ & $\begin{array}{l}\text { P IIME } \\
\text { (S) }\end{array}$ & $\begin{array}{l}\text { CORR } \\
\text { P TIHE } \\
\text { (S) }\end{array}$ & $\begin{array}{l}\text { AVE VEL } \\
P \text { WAVE } \\
(B / S)\end{array}$ \\
\hline
\end{tabular}

0.058

262

234

271

272

300

$\begin{array}{rlllll}2.5 & 0.018 & 0.014 & 0.008 & 0.006 & 400 \\ 5.0 & 0.026 & 0.024 & 0.010 & 0.009 & 538 \\ 7.5 & 0.039 & 0.037 & 0.011 & 0.011 & 705 \\ 10.0 & 0.053 & 0.052 & 0.013 & 0.013 & 784 \\ 12.5 & 0.053 & 0.052 & 0.014 & 0.014 & 904 \\ 15.0 & 0.062 & 0.061 & 0.017 & 0.017 & 890 \\ 17.5 & 0.066 & 0.065 & 0.030 & 0.030 & 587\end{array}$


TABLE 7

IEAVEI-TIRES AAD AVZBAGE VELCCITIES

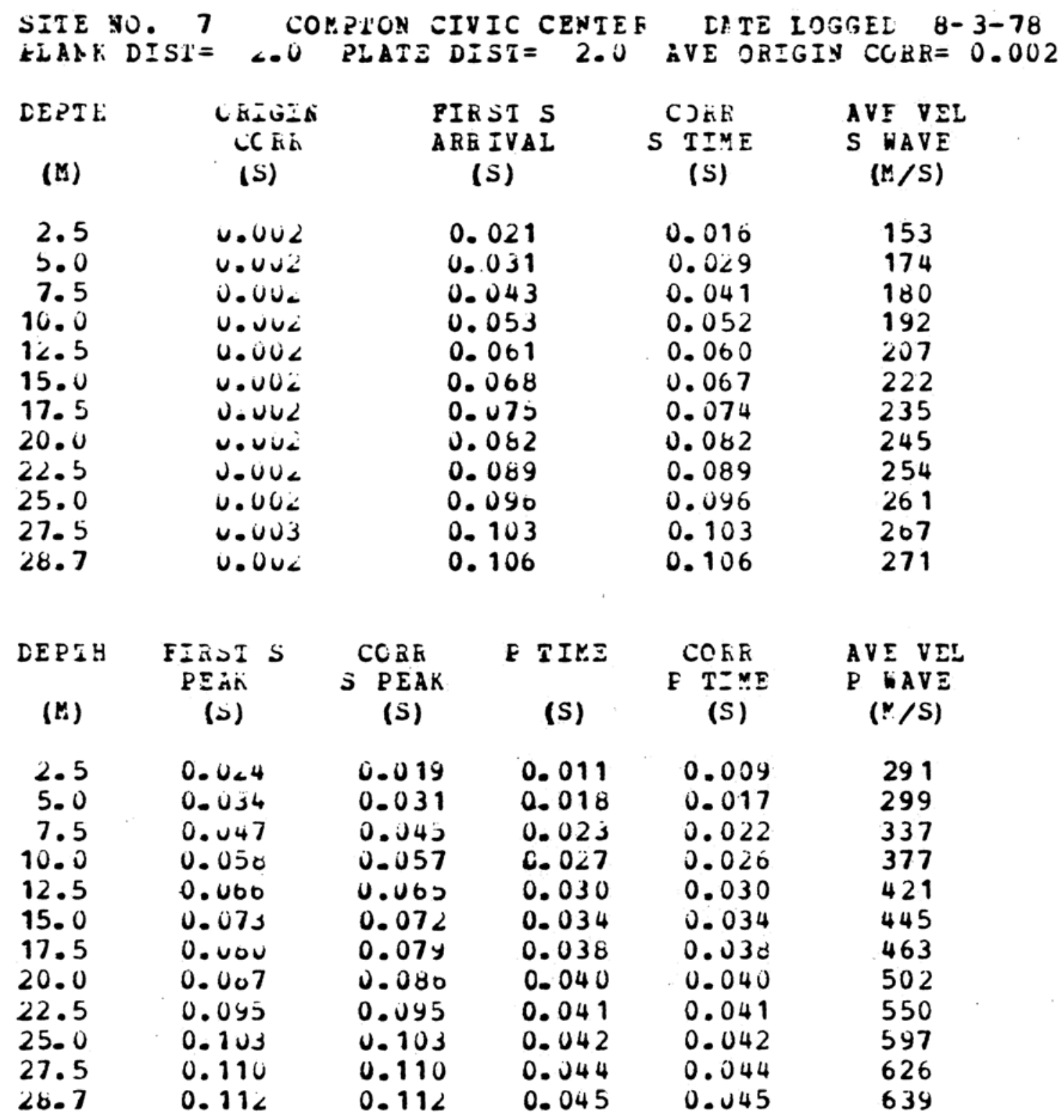


TABLE 8

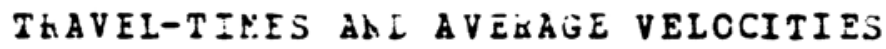

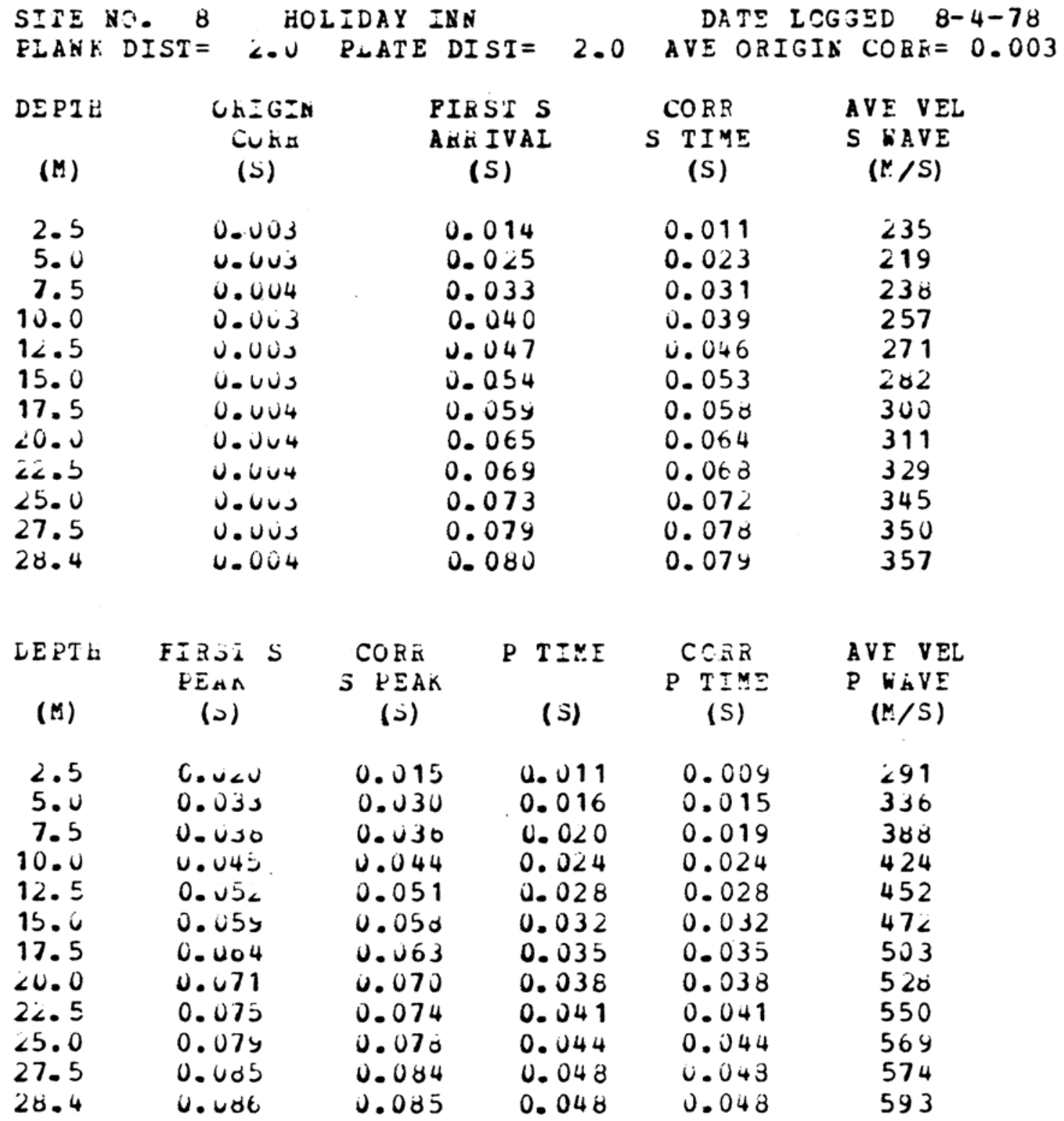


TABLE 9

TRAVEI-TIYES AAD AVZKAGE VELOCITIES

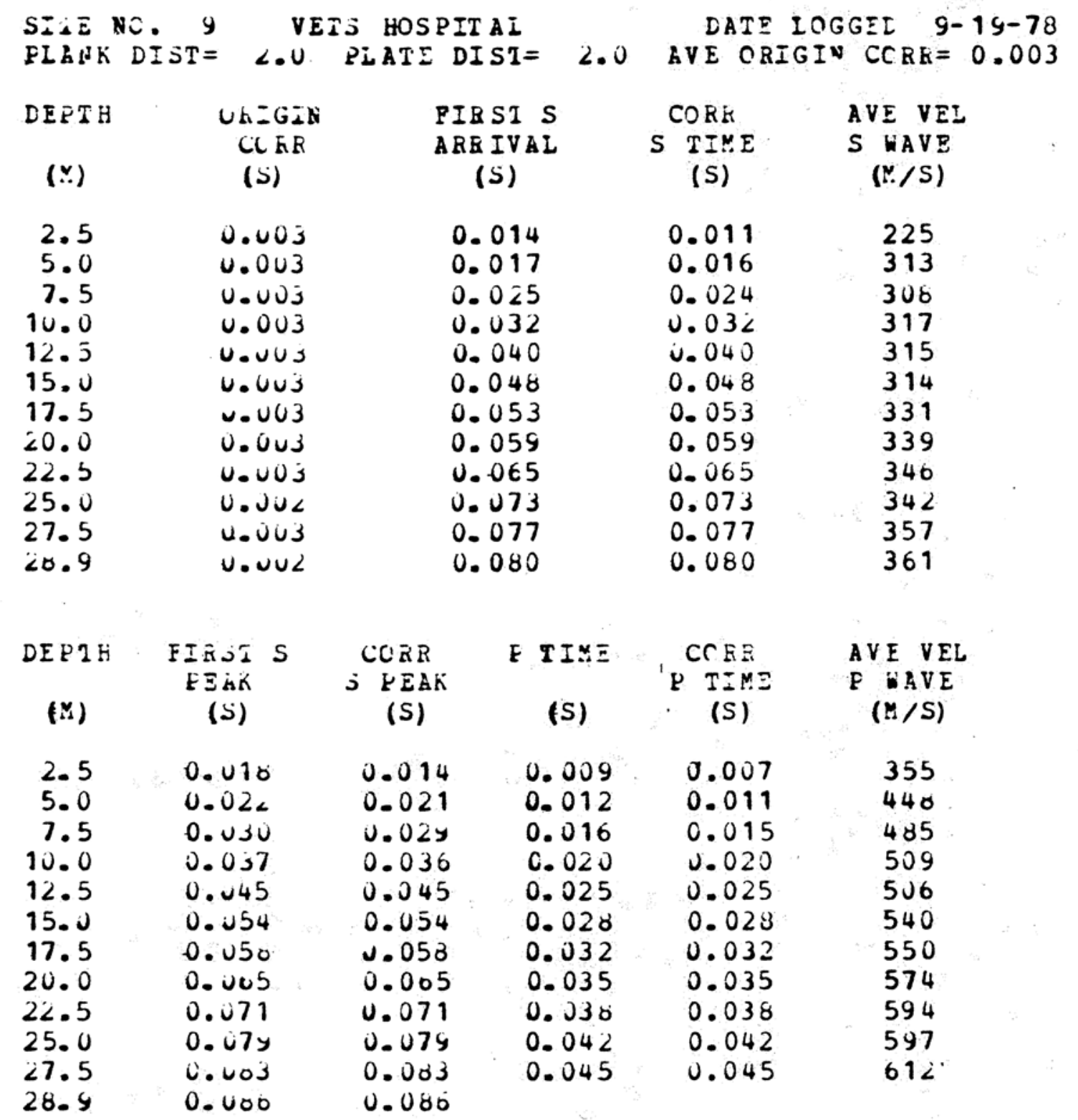


TABLE 10

I HAVEI-TIMES ALL AVEKAGE VELOCITIES

\begin{tabular}{|c|c|c|c|c|c|}
\hline $\begin{array}{c}\text { DEPTH } \\
(\mathbb{K})\end{array}$ & $\begin{array}{l}\text { CKIGIN } \\
\text { CUIR } \\
\text { (S) }\end{array}$ & & $\begin{array}{l}\text { SI S } \\
\text { IVAI } \\
\text { S) }\end{array}$ & 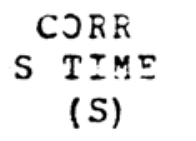 & $\begin{array}{c}\text { AVE VEL } \\
S \text { HAVE } \\
(\because / S)\end{array}$ \\
\hline $\begin{array}{l}2.5 \\
5.0 \\
7.5 \\
9.2 \\
11.3 \\
13.5 \\
16.0 \\
18.5 \\
21.0 \\
23.5 \\
26.0 \\
20.5 \\
31.0 \\
33.5 \\
36.0 \\
30.5 \\
41.0 \\
43.5 \\
46.0\end{array}$ & 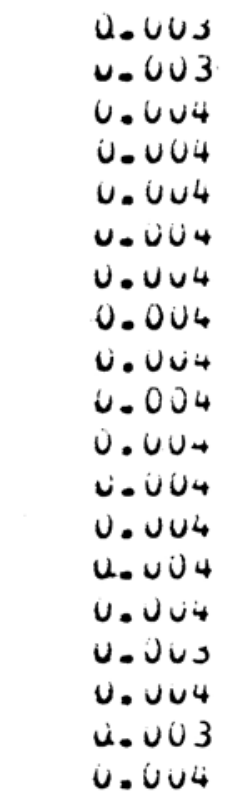 & & $\begin{array}{l}014 \\
042 \\
052 \\
060 \\
071 \\
077 \\
088 \\
099 \\
108 \\
114 \\
129 \\
140 \\
151 \\
157 \\
167 \\
175 \\
182 \\
168 \\
196\end{array}$ & $\begin{array}{l}0.015 \\
0.039 \\
0.050 \\
0.065 \\
0.070 \\
0.076 \\
0.008 \\
0.099 \\
0.108 \\
0.119 \\
0.129 \\
0.140 \\
0.151 \\
0.157 \\
0.167 \\
0.175 \\
0.182 \\
0.188 \\
0.196\end{array}$ & $\begin{array}{l}166 \\
127 \\
148 \\
142 \\
161 \\
176 \\
182 \\
187 \\
144 \\
197 \\
201 \\
203 \\
205 \\
213 \\
215 \\
220 \\
225 \\
231 \\
234\end{array}$ \\
\hline $\begin{array}{c}D E P T \ddot{I} \\
\text { (M) }\end{array}$ & $\begin{array}{c}F I R D I \\
F \equiv \operatorname{LiK} \\
(S)\end{array}$ & $\begin{array}{c}E \bar{K} \text {. } \\
\text { S PEAK } \\
\text { (S) }\end{array}$ & $\begin{array}{c}\text { E TINE } \\
\text { (S) }\end{array}$ & $\begin{array}{c}\text { COER } \\
P \text { TINE } \\
\text { (S) }\end{array}$ & $\begin{array}{c}A V E V E L \\
P \quad A V E \\
(M / S)\end{array}$ \\
\hline $\begin{array}{l}2.5 \\
5.0 \\
7.5 \\
9.0 \\
11.3 \\
13.5 \\
10.0 \\
16.5 \\
21.0 \\
23.5 \\
26.0 \\
28.5 \\
31.0 \\
33.5 \\
36.0 \\
38.5 \\
41.0 \\
43.5 \\
46.0\end{array}$ & $\begin{array}{l}0.0<4 \\
0.047 \\
0.057 \\
0.072 \\
0.076 \\
0.00< \\
0.094 \\
0.105 \\
0.114 \\
0.125 \\
0.135 \\
0.140 \\
0.157 \\
0.103 \\
0.173 \\
0.101 \\
0.100 \\
0.154 \\
0.20<\end{array}$ & $\begin{array}{l}0.014 \\
0.044 \\
0.055 \\
0.071 \\
0.075 \\
0.081 \\
0.043 \\
0.105 \\
0.114 \\
0.125 \\
0.135 \\
0.146 \\
0.157 \\
0.163 \\
0.173 \\
0.181 \\
0.138 \\
0.194 \\
0.202\end{array}$ & $\begin{array}{l}0.004 \\
0.016 \\
0.020 \\
0.021 \\
0.0<2 \\
0.024 \\
0.031 \\
0.032 \\
0.033 \\
0.035\end{array}$ & $\begin{array}{l}0.007 \\
0.015 \\
0.019 \\
0.021 \\
0.022 \\
0.024 \\
0.031 \\
0.032 \\
0.033 \\
0.035\end{array}$ & $\begin{array}{l}355 \\
336 \\
388 \\
448 \\
521 \\
568 \\
520 \\
581 \\
639 \\
673\end{array}$ \\
\hline
\end{tabular}


TABLE 11

TAAVEI-TIRES AN D AVEKGE VELCCITIFS

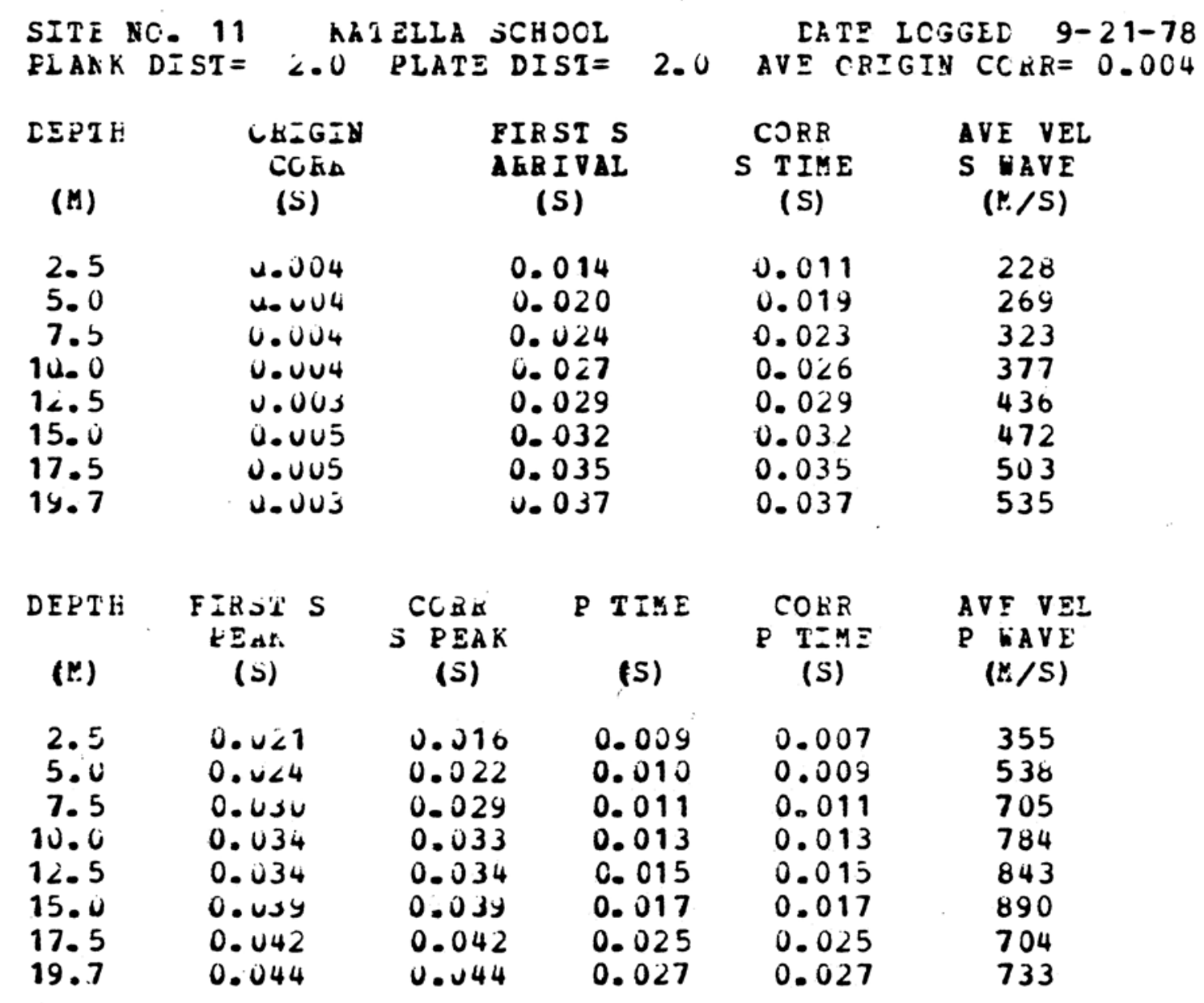


TKAVEI-TEMES AN A RERAGE VELOCITIES

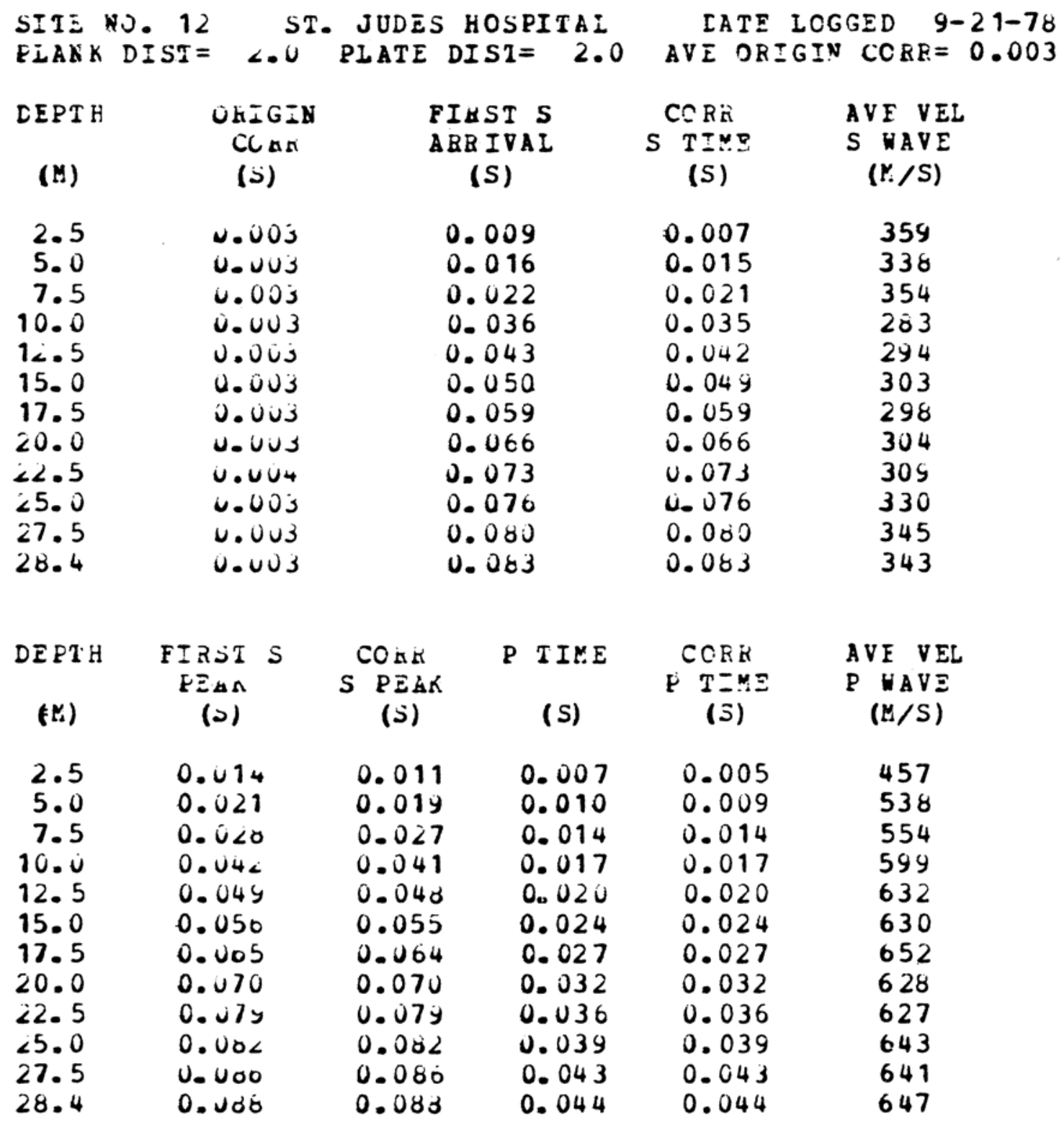


TABLE 13

THGVEZ-TIRES AND AVEAAGE VEICCITIES

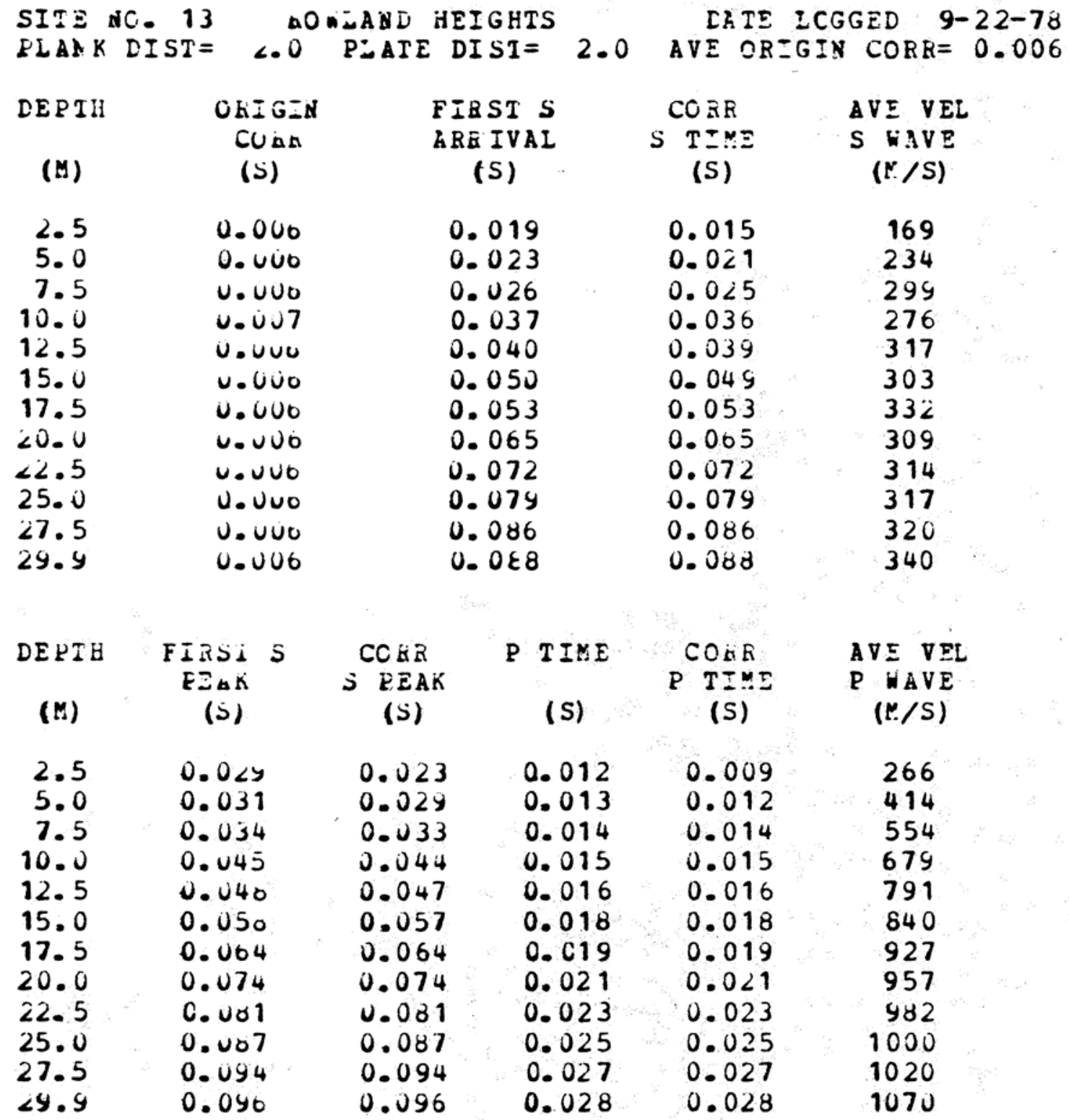


TABLE 14

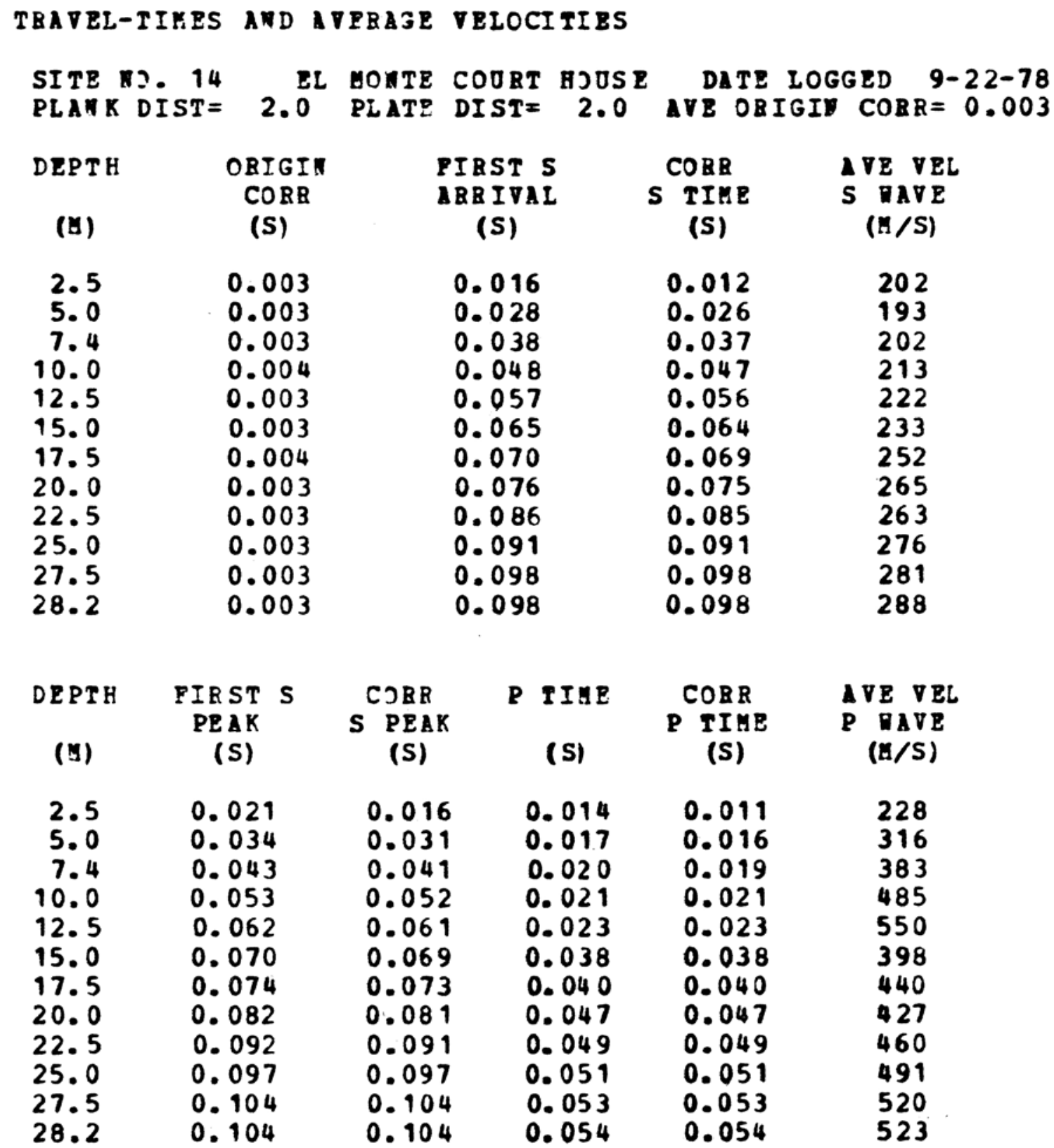


TABLE 15

TAREEI-tíES AML AVZRAGE VELOCITIES

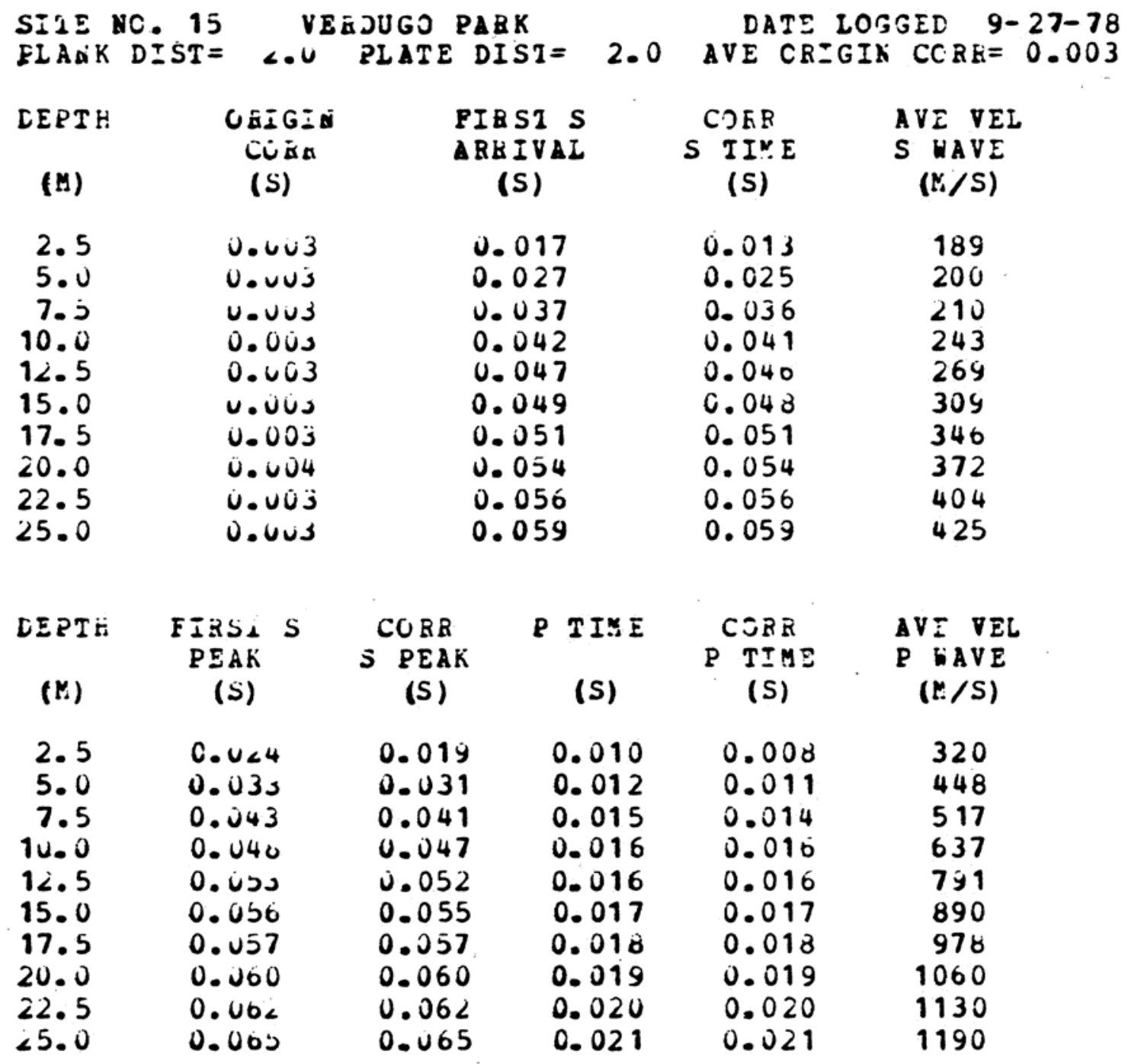


TABLE 16

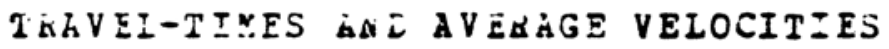

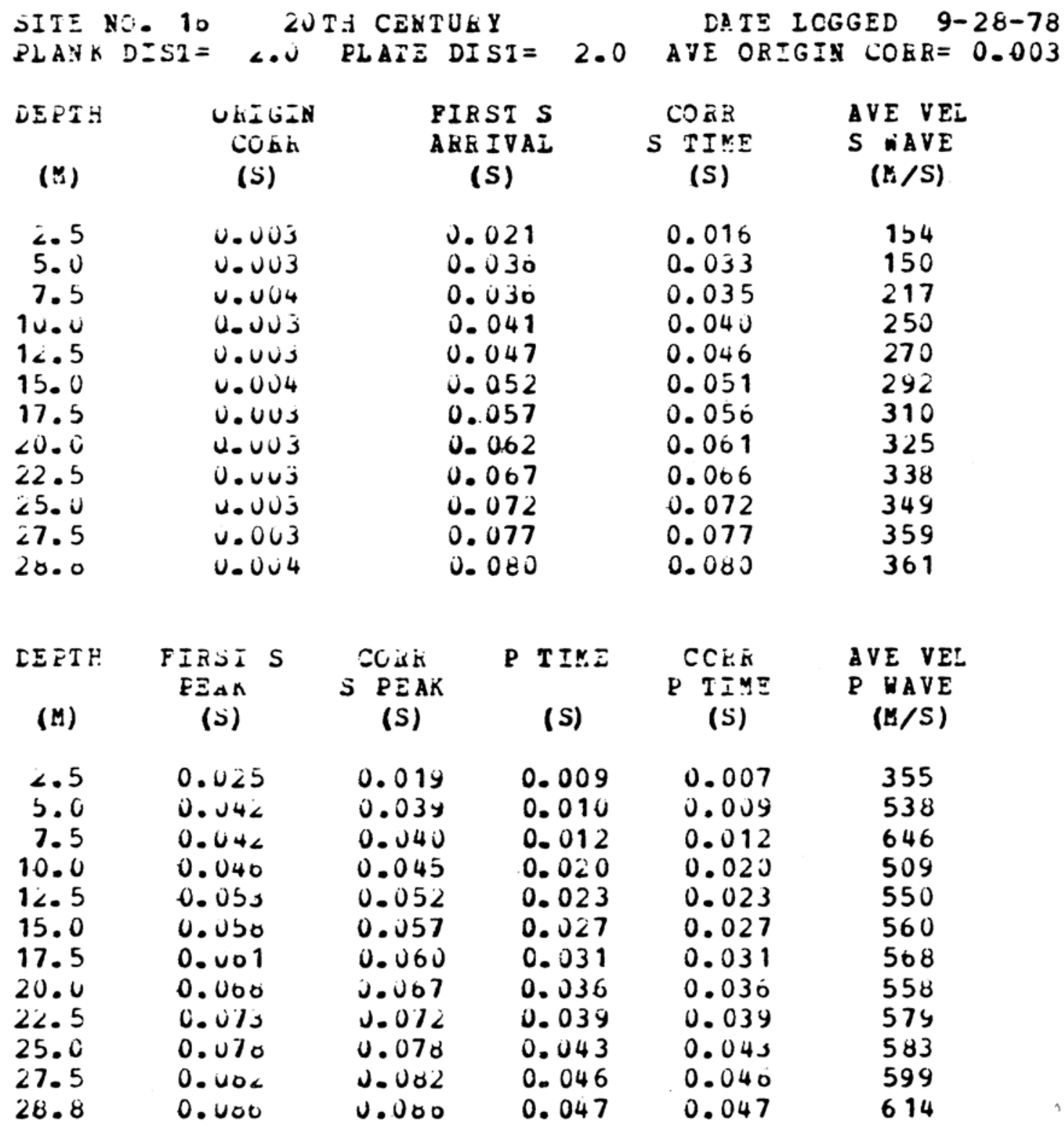


TABLE 17

TÉVEITTEES AN D AVEAGE VELOCITIES

\begin{tabular}{|c|c|c|c|c|c|}
\hline $\begin{array}{l}\text { DEFT H } \\
\text { (E) }\end{array}$ & $\begin{array}{l}\text { CKIGIN } \\
\text { CCLIS } \\
\text { (S) }\end{array}$ & & $\begin{array}{l}\text { ST S } \\
\text { I VAL } \\
\text { b) }\end{array}$ & $\begin{array}{c}\text { C2RK } \\
S \quad T I M E \\
\text { (S) }\end{array}$ & $\begin{array}{c}A V F \text { VEL } \\
S \text { WAVE } \\
(E / S)\end{array}$ \\
\hline $\begin{array}{r}2.5 \\
5.0 \\
7.5 \\
10.0 \\
12.5 \\
15.0 \\
17.5 \\
20.0 \\
22.5 \\
25.0 \\
26.3\end{array}$ & 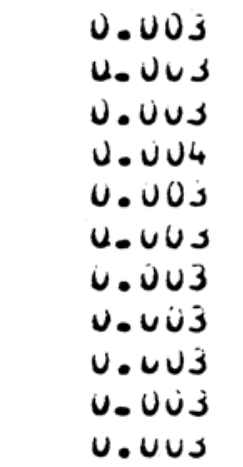 & & $\begin{array}{l}13 \\
023 \\
34 \\
346 \\
54 \\
064 \\
72 \\
00 \\
086 \\
093 \\
06\end{array}$ & $\begin{array}{l}0.010 \\
0.021 \\
0.033 \\
0.045 \\
0.053 \\
0.063 \\
0.071 \\
0.080 \\
0.086 \\
0.093 \\
0.096\end{array}$ & $\begin{array}{l}248 \\
235 \\
228 \\
222 \\
234 \\
236 \\
244 \\
251 \\
262 \\
269 \\
275\end{array}$ \\
\hline $\begin{array}{l}L E P T E \\
\left(M_{1}\right)\end{array}$ & $\begin{array}{c}\text { Finjt S } \\
\text { Piinh } \\
\text { (S) }\end{array}$ & $\begin{array}{c}\text { CORK } \\
\text { S PEAK } \\
\text { (S) }\end{array}$ & $\begin{array}{l}\text { P TIKE } \\
\text { (S) }\end{array}$ & $\begin{array}{l}\text { CORE } \\
\text { P TIME } \\
\text { (S) }\end{array}$ & $\begin{array}{c}\text { AVE VEL } \\
P \text { WAVE } \\
(H / S)\end{array}$ \\
\hline $\begin{array}{r}2.5 \\
5.0 \\
7.5 \\
10.0 \\
12.5 \\
15.0 \\
17.5 \\
20.0 \\
22.5 \\
25.0 \\
26.3\end{array}$ & $\begin{array}{l}C .0<v \\
0.0<y \\
0 . v 40 \\
0 . v j 1 \\
0.05 y \\
0 . v 05 \\
0.077 \\
0 . v 85 \\
0.0 y 1 \\
0.040 \\
0.1 v 1\end{array}$ & $\begin{array}{l}0.016 \\
0.027 \\
0.039 \\
0.050 \\
0.050 \\
0.068 \\
0.070 \\
0.084 \\
0.091 \\
0.098 \\
0.101\end{array}$ & $\begin{array}{l}0.010 \\
0.015 \\
0.019 \\
0.021 \\
0.022 \\
0.024 \\
0.025 \\
0.026 \\
0.027 \\
0.028 \\
0.029\end{array}$ & $\begin{array}{l}0.008 \\
0.014 \\
0.018 \\
0.021 \\
0.022 \\
0.024 \\
0.025 \\
0.026 \\
0.0227 \\
0.028 \\
0.029\end{array}$ & $\begin{array}{l}320 \\
359 \\
408 \\
485 \\
575 \\
630 \\
704 \\
773 \\
836 \\
895 \\
909\end{array}$ \\
\hline
\end{tabular}


TABLE 18

TEAVEI-TIMES AA D AVẼAgE VELCCITIES

\begin{tabular}{|c|c|c|c|c|c|}
\hline $\begin{array}{c}\text { LERTE } \\
(M)\end{array}$ & $\begin{array}{l}\text { UhIGiN } \\
\text { CLkn } \\
\text { (S) }\end{array}$ & & $\begin{array}{l}\text { SI } S \\
\text { IVAI } \\
\text { 5) }\end{array}$ & $\begin{array}{c}\text { COKR } \\
S \begin{array}{c}\text { TIRE } \\
\text { (S) }\end{array}\end{array}$ & $\begin{array}{c}\text { AVE VEL } \\
S \text { WVE } \\
(Y / S)\end{array}$ \\
\hline $\begin{array}{l}2.5 \\
5.0 \\
7.5 \\
10.0 \\
12.5 \\
15.0 \\
17.5 \\
20.0 \\
22.5 \\
25.0 \\
27.5 \\
29.7\end{array}$ & 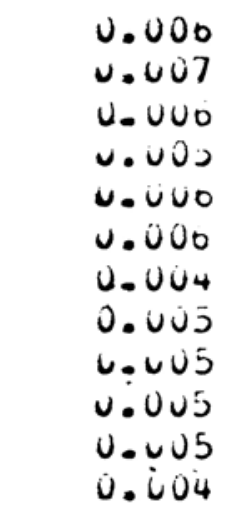 & & $\begin{array}{l}030 \\
339 \\
50 \\
57 \\
064 \\
71 \\
077 \\
011 \\
086 \\
091 \\
045 \\
099\end{array}$ & $\begin{array}{l}0.023 \\
0.036 \\
0.048 \\
0.056 \\
0.063 \\
0.070 \\
0.070 \\
0.080 \\
0.085 \\
0.090 \\
0.094 \\
0.098\end{array}$ & $\begin{array}{l}107 \\
139 \\
156 \\
179 \\
198 \\
214 \\
229 \\
249 \\
263 \\
276 \\
291 \\
301\end{array}$ \\
\hline $\begin{array}{c}\text { IE P I H } \\
(\mathrm{K})\end{array}$ & $\begin{array}{c}\text { FIRSI } \\
\text { PEAK } \\
\text { (S) }\end{array}$ & 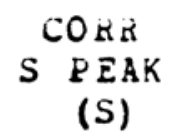 & $\begin{array}{c}E \text { TIYE } \\
\text { (S) }\end{array}$ & $\begin{array}{c}\text { CORR } \\
\text { P TIME } \\
\text { (S). }\end{array}$ & $\begin{array}{c}\text { AVE VEL } \\
P \text { WAVE } \\
(Y / S)\end{array}$ \\
\hline $\begin{array}{r}2.5 \\
5.0 \\
7.5 \\
10.0 \\
12.5 \\
15.0 \\
17.5 \\
20.0 \\
22.5 \\
25.0 \\
27.5 \\
29.7\end{array}$ & $\begin{array}{l}0.053 \\
0.061 \\
0.072 \\
0.070 \\
0.005 \\
0.051 \\
0.057 \\
0.105 \\
0.105 \\
0.105 \\
0.114 \\
0.117\end{array}$ & $\begin{array}{l}0.041 \\
0.050 \\
0.069 \\
0.070 \\
0.082 \\
0.090 \\
0.090 \\
0.101 \\
0.104 \\
0.108 \\
0.113 \\
0.116\end{array}$ & $\begin{array}{l}0.013 \\
0.014 \\
0.016 \\
0.018 \\
0.018 \\
0.019 \\
0.021 \\
0.023 \\
0.025 \\
0.027 \\
0.055 \\
0.058\end{array}$ & $\begin{array}{l}0.010 \\
0.013 \\
0.015 \\
0.018 \\
0.018 \\
0.019 \\
0.021 \\
0.023 \\
0.025 \\
0.027 \\
0.055 \\
0.058\end{array}$ & $\begin{array}{l}246 \\
384 \\
485 \\
566 \\
703 \\
796 \\
838 \\
873 \\
903 \\
928 \\
501 \\
513\end{array}$ \\
\hline
\end{tabular}


TABLE 19

ThAVEI-TIMES AL. L AVERRGE VELOCITIES

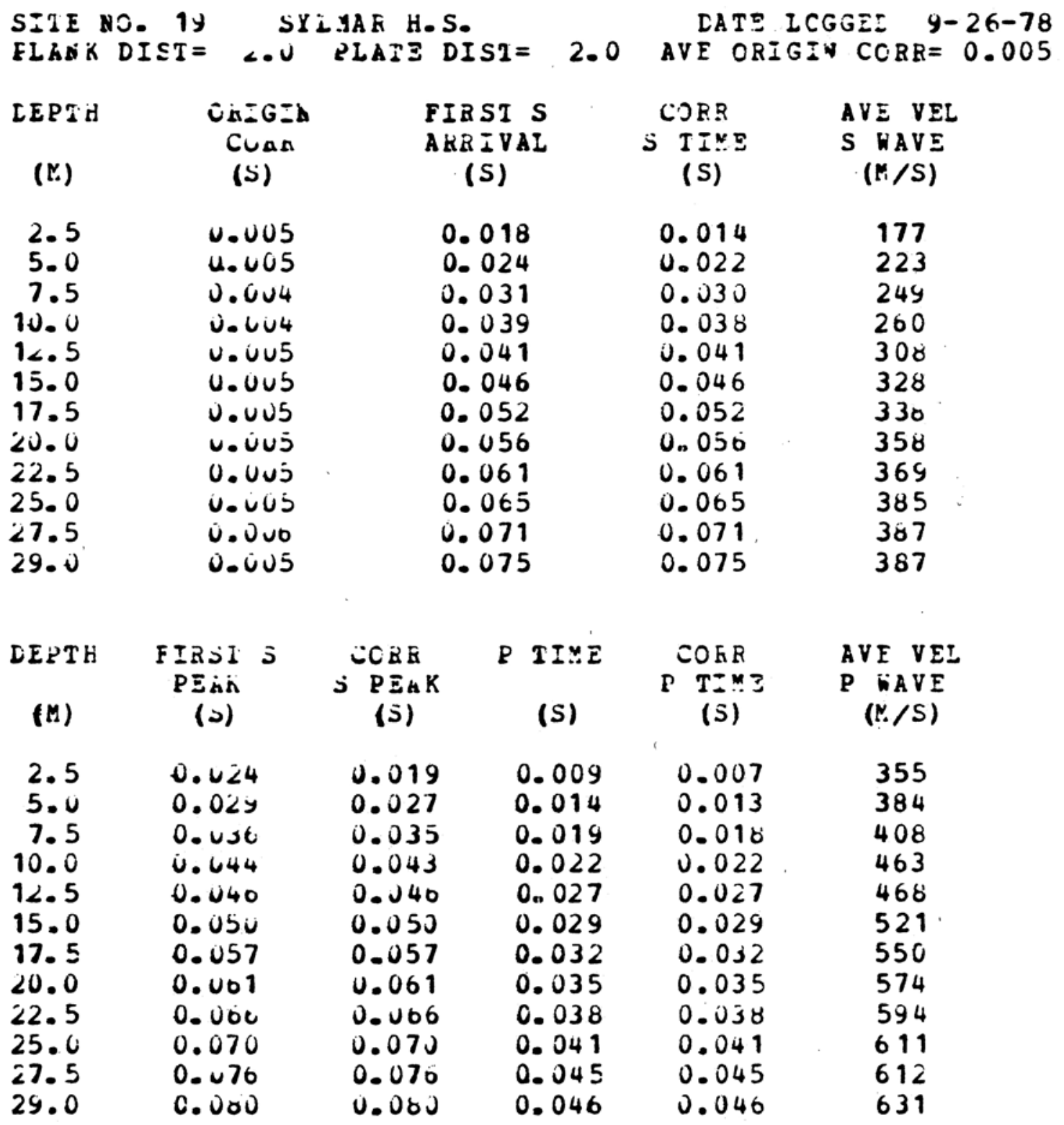


TKAVELTILES AAD AVEKAGE VELOCITIES

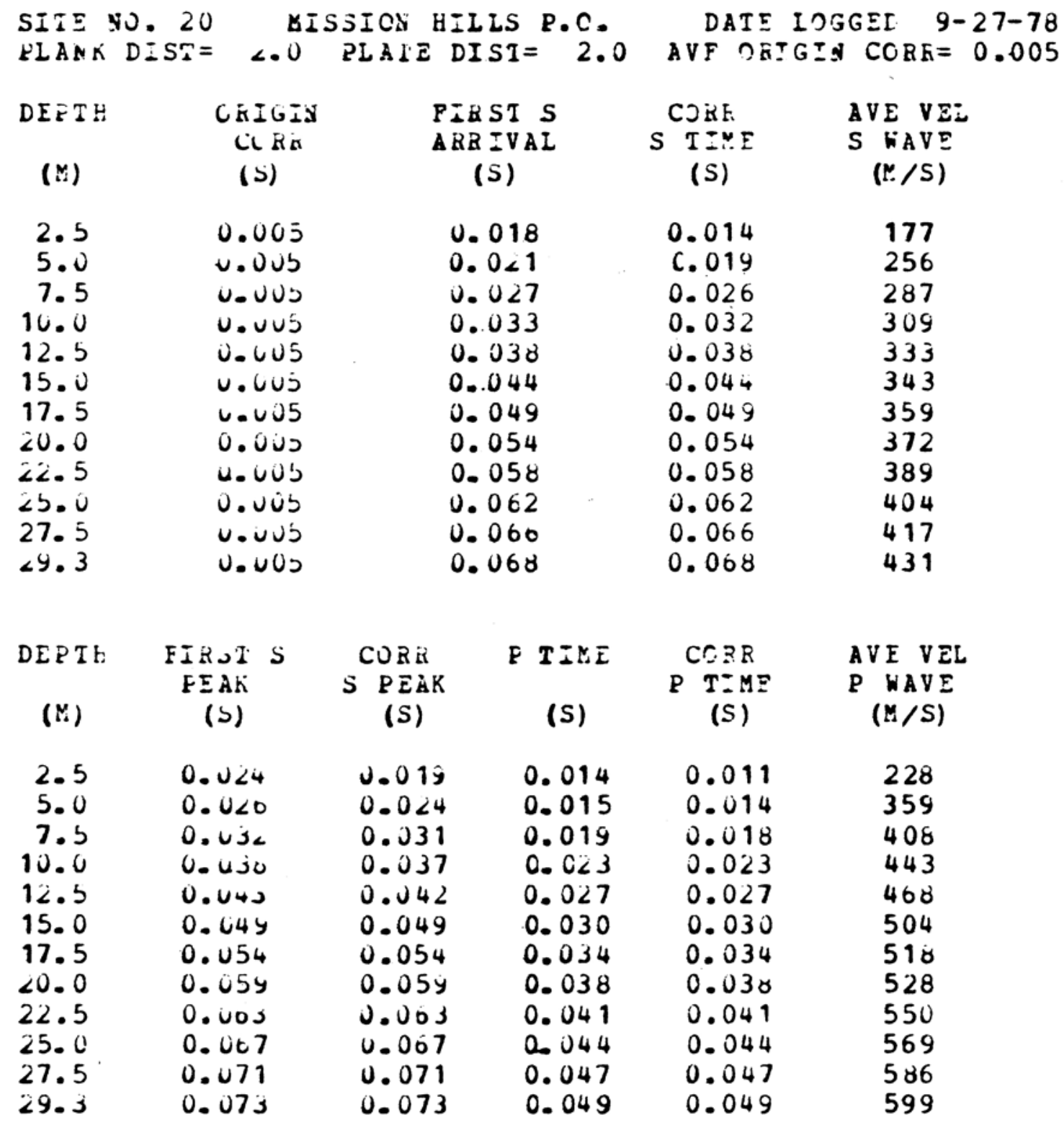


TABLE 21

ThAVEI-TIMES AS D AVEAGE VELOCITIES

\begin{tabular}{|c|c|c|c|c|c|c|}
\hline \multicolumn{4}{|c|}{$\begin{array}{l}\text { SITE NC. } 21 \\
\text { ELANK DIST }=\quad \text { EI }\end{array}$} & \multicolumn{3}{|c|}{$\begin{array}{l}\text { IATE IJGGEI } 9-28-78 \\
\text { VE DBIGIN CCEK }=0.006\end{array}$} \\
\hline $\begin{array}{l}\text { DEPTH } \\
\text { (N) }\end{array}$ & $\begin{array}{l}\text { UKIGIN } \\
\text { CCAn } \\
\text { (S) }\end{array}$ & & $\begin{array}{l}\text { ST } S \\
\text { IVAI } \\
\text { S) }\end{array}$ & $\begin{aligned} \text { CORR } \\
S \quad \text { TIME } \\
(S)\end{aligned}$ & $\begin{array}{l}\text { AVE VEL } \\
S \text { WAVE } \\
(Y / S)\end{array}$ & \\
\hline $\begin{array}{l}2.5 \\
5.0 \\
7.5 \\
10.0 \\
12.5 \\
15.0 \\
17.5 \\
20.0 \\
22.5 \\
25.0 \\
27.5 \\
29.6\end{array}$ & $\begin{array}{l}\text { U.006 } \\
0.005 \\
u .000 \\
u .000 \\
0.00 J \\
0.006 \\
\text { U.0U7 } \\
\text { U. U06 } \\
\text { U. U00 } \\
\text { U. U06 } \\
\text { U. OUO } \\
\text { U. U00 }\end{array}$ & & $\begin{array}{l}015 \\
027 \\
038 \\
046 \\
057 \\
069 \\
076 \\
086 \\
095 \\
103 \\
113 \\
118\end{array}$ & $\begin{array}{l}0.012 \\
0.025 \\
0.037 \\
0.047 \\
0.056 \\
0.063 \\
0.076 \\
0.086 \\
0.045 \\
0.103 \\
0.113 \\
0.118\end{array}$ & $\begin{array}{l}212 \\
198 \\
203 \\
212 \\
214 \\
219 \\
231 \\
233 \\
237 \\
243 \\
243 \\
251\end{array}$ & \\
\hline $\begin{array}{c}\text { DEPTH } \\
\text { (M) }\end{array}$ & 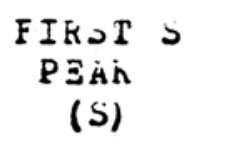 & $\begin{array}{c}\text { CORK } \\
S \begin{array}{l}\text { PEAK } \\
\text { (S) }\end{array}\end{array}$ & $\begin{array}{c}\text { E TIME } \\
\text { (S) }\end{array}$ & $\begin{array}{c}\text { CORR } \\
\text { P TENE } \\
(S)\end{array}$ & $\begin{array}{l}\text { AVE VEL } \\
\text { P VAVE } \\
(H . / S)\end{array}$ & \\
\hline $\begin{array}{l}2.5 \\
5.0 \\
7.5 \\
10.0 \\
12.5 \\
15.0 \\
17.5 \\
20.0 \\
22.5 \\
25.0 \\
27.5 \\
29.6\end{array}$ & $\begin{array}{l}\text { C. U2u } \\
0.034 \\
0.040 \\
0.055 \\
0.005 \\
0.070 \\
0.003 \\
0.044 \\
0.143 \\
0.111 \\
0.121 \\
0.121\end{array}$ & $\begin{array}{l}0.016 \\
0.032 \\
0.045 \\
0.054 \\
0.064 \\
0.075 \\
0.083 \\
0.094 \\
0.103 \\
0.111 \\
0.121 \\
0.127\end{array}$ & $\begin{array}{l}0.013 \\
0.014 \\
0.017 \\
0.022 \\
0.023 \\
0.024 \\
0.025 \\
0.027 \\
0.028 \\
0.029 \\
0.031 \\
0.032\end{array}$ & $\begin{array}{l}0.010 \\
0.013 \\
0.016 \\
0.022 \\
0.023 \\
0.024 \\
0.025 \\
0.027 \\
0.023 \\
0.029 \\
0.031 \\
0.032\end{array}$ & $\begin{array}{l}246 \\
384 \\
456 \\
463 \\
550 \\
630 \\
704 \\
744 \\
806 \\
864 \\
889 . \\
927\end{array}$ & \\
\hline
\end{tabular}


TEAVEI-TIRES AAD AVEAAGE VELCCITIES

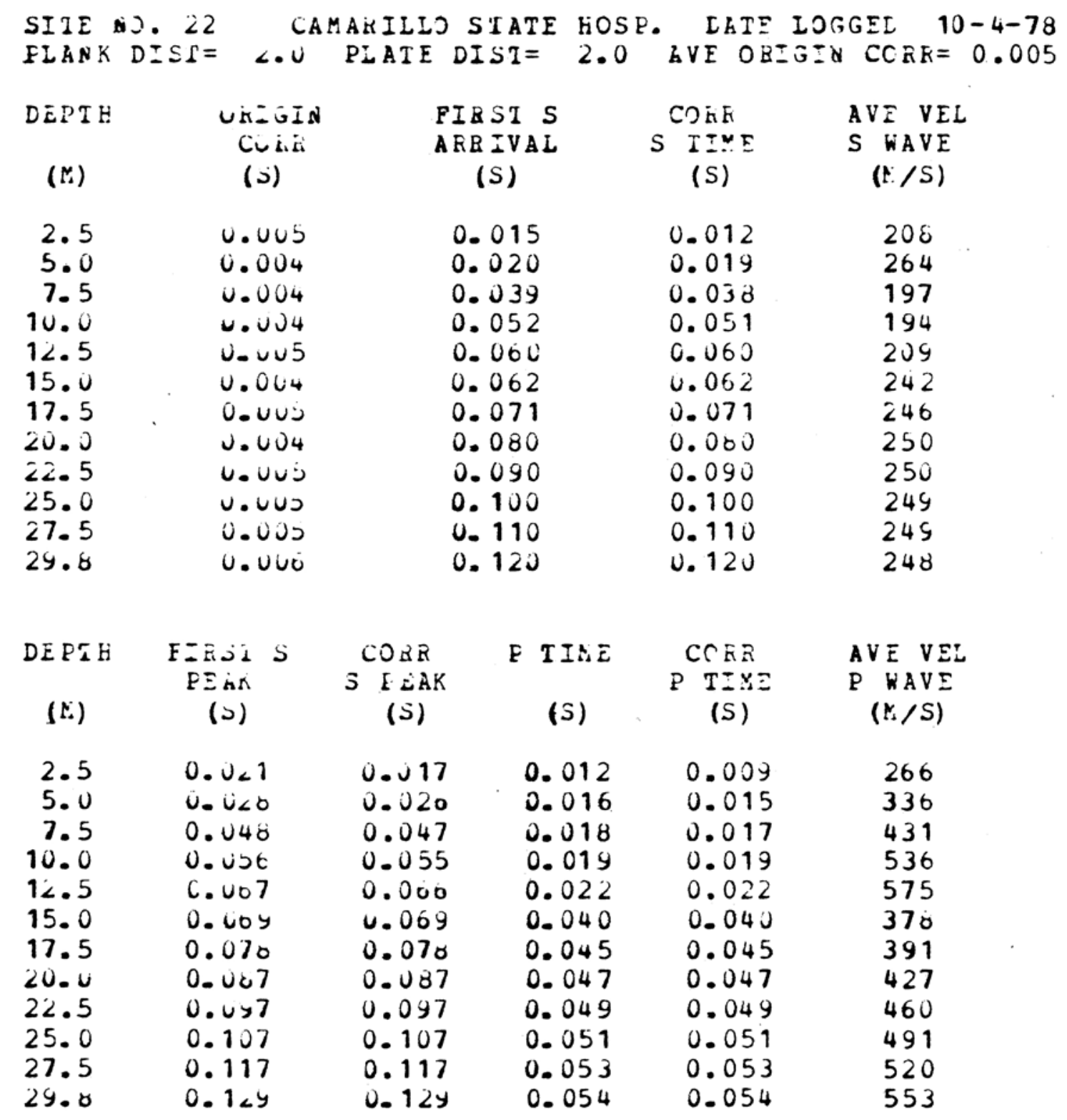


TABLE 23

TRAVEL-TIYES AND AVERAGE VELOCITIES

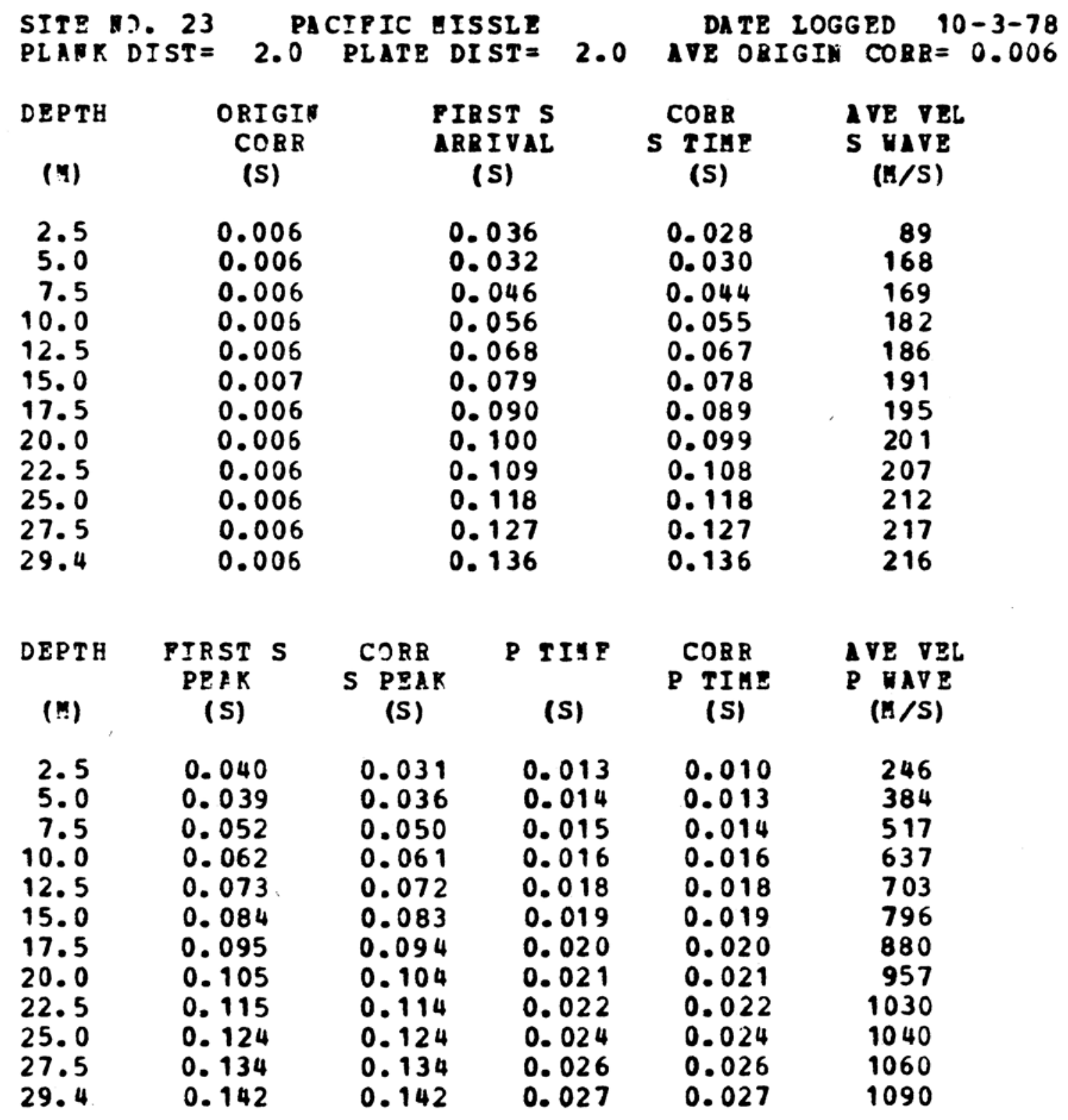


TABLE 24

I RAVEI-TIMES AWD AVERAGE VEICCITIES

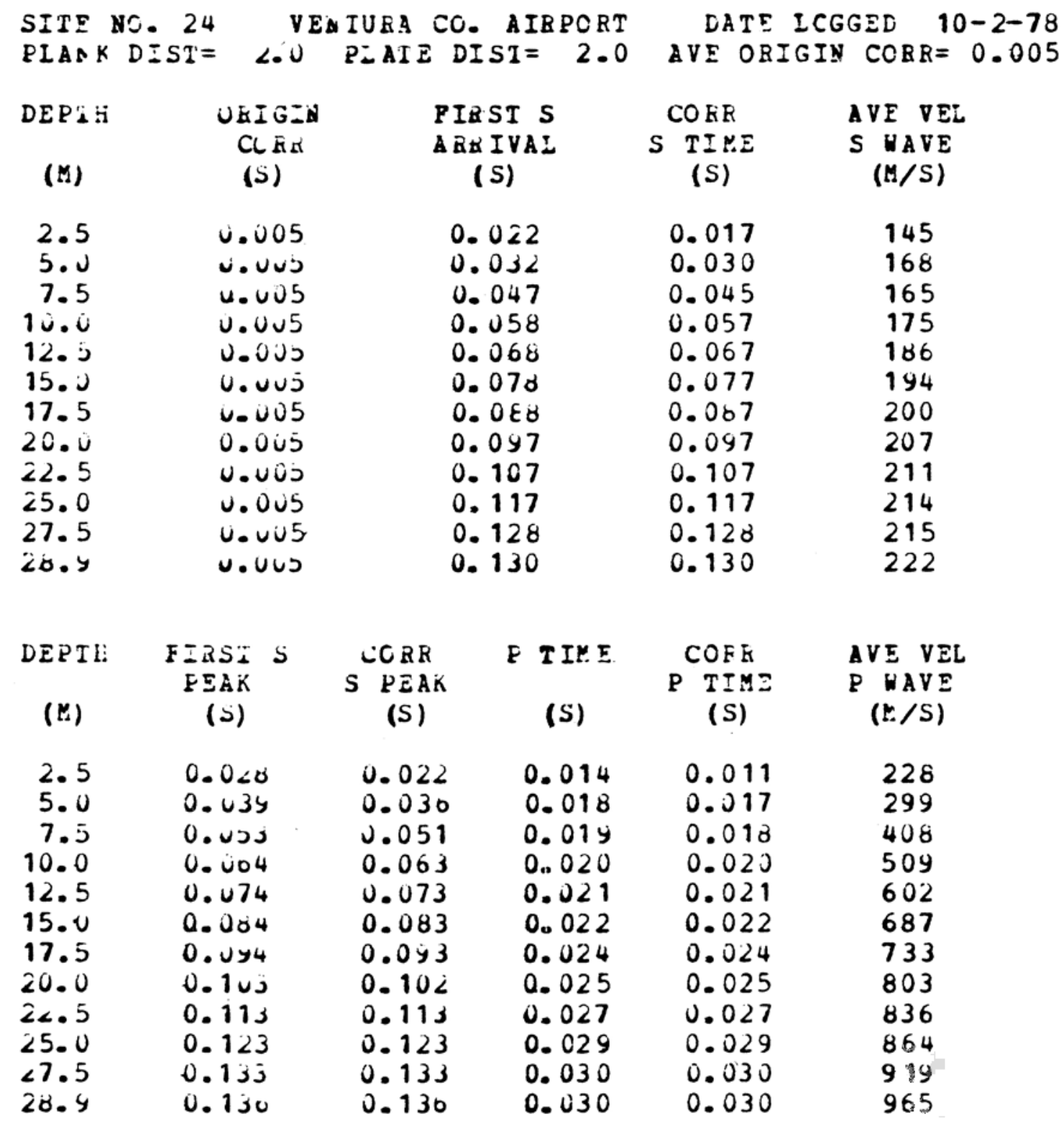


TABLE 25

\section{TRAVEL-IIMES AED AVERAGE VELOCITIES}

\begin{tabular}{|c|c|c|c|c|c|}
\hline $\begin{array}{c}\text { DEPTH } \\
\text { (H) }\end{array}$ & $\begin{array}{c}\text { ORIGIN } \\
\text { CDBR } \\
\text { (S) }\end{array}$ & & $\begin{array}{l}S T S \\
\text { IVAL } \\
\text { S) }\end{array}$ & 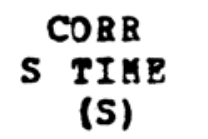 & $\begin{array}{c}A V E \text { VEL } \\
S \underset{A V B}{(H / S)}\end{array}$ \\
\hline $\begin{array}{r}2.5 \\
5.0 \\
7.5 \\
10.0 \\
12.5 \\
15.0 \\
17.5 \\
20.0 \\
22.5 \\
25.0 \\
27.5 \\
29.5\end{array}$ & $\begin{array}{l}0.005 \\
0.005 \\
0.005 \\
0.005 \\
0.005 \\
0.005 \\
0.005 \\
0.005 \\
0.005 \\
0.005 \\
0.004 \\
0.005\end{array}$ & & $\begin{array}{l}023 \\
025 \\
036 \\
046 \\
056 \\
066 \\
076 \\
086 \\
098 \\
106 \\
112 \\
118\end{array}$ & $\begin{array}{l}0.018 \\
0.023 \\
0.035 \\
0.045 \\
0.055 \\
0.066 \\
0.076 \\
0.086 \\
0.098 \\
0.106 \\
0.1112 \\
0.118\end{array}$ & $\begin{array}{l}138 \\
214 \\
215 \\
221 \\
225 \\
228 \\
231 \\
233 \\
230 \\
236 \\
246 \\
250\end{array}$ \\
\hline $\begin{array}{l}\text { DEPTH } \\
\text { (A) }\end{array}$ & $\begin{array}{c}\text { FIRST } S \\
\text { PEAR } \\
\text { (S) }\end{array}$ & 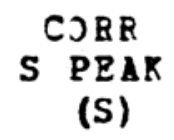 & $\begin{array}{c}\text { P TIUE } \\
\text { (S) }\end{array}$ & $\begin{array}{l}\text { CORB } \\
\text { P TIME } \\
\text { (S) }\end{array}$ & $\begin{array}{c}A V E \nabla B L \\
P \quad A V E \\
(E / S)\end{array}$ \\
\hline $\begin{array}{r}2.5 \\
5.0 \\
7.5 \\
10.0 \\
12.5 \\
15.0 \\
17.5 \\
20.0 \\
22.5 \\
25.0 \\
27.5 \\
29.5\end{array}$ & $\begin{array}{l}0.028 \\
0.030 \\
0.041 \\
0.051 \\
0.061 \\
0.071 \\
0.081 \\
0.092 \\
0.104 \\
0.112 \\
0.117 \\
0.123\end{array}$ & $\begin{array}{l}0.022 \\
0.028 \\
0.040 \\
0.050 \\
0.060 \\
0.070 \\
0.081 \\
0.092 \\
0.104 \\
0.112 \\
0.117 \\
0.123\end{array}$ & $\begin{array}{l}0.010 \\
0.012 \\
0.0114 \\
0.015 \\
0.017 \\
0.019 \\
0.022 \\
0.022 \\
0.024 \\
0.025 \\
0.028\end{array}$ & $\begin{array}{l}0.008 \\
0.011 \\
0.014 \\
0.015 \\
0.017 \\
0.019 \\
0.022 \\
0.022 \\
0.024 \\
0.025 \\
0.028\end{array}$ & $\begin{array}{r}320 \\
448 \\
554 \\
679 \\
744 \\
796 \\
880 \\
913 \\
941 \\
1000 \\
984\end{array}$ \\
\hline
\end{tabular}


TABLE 26

TRAVEI-IIEES AFD AVERAGE VELOCITIES

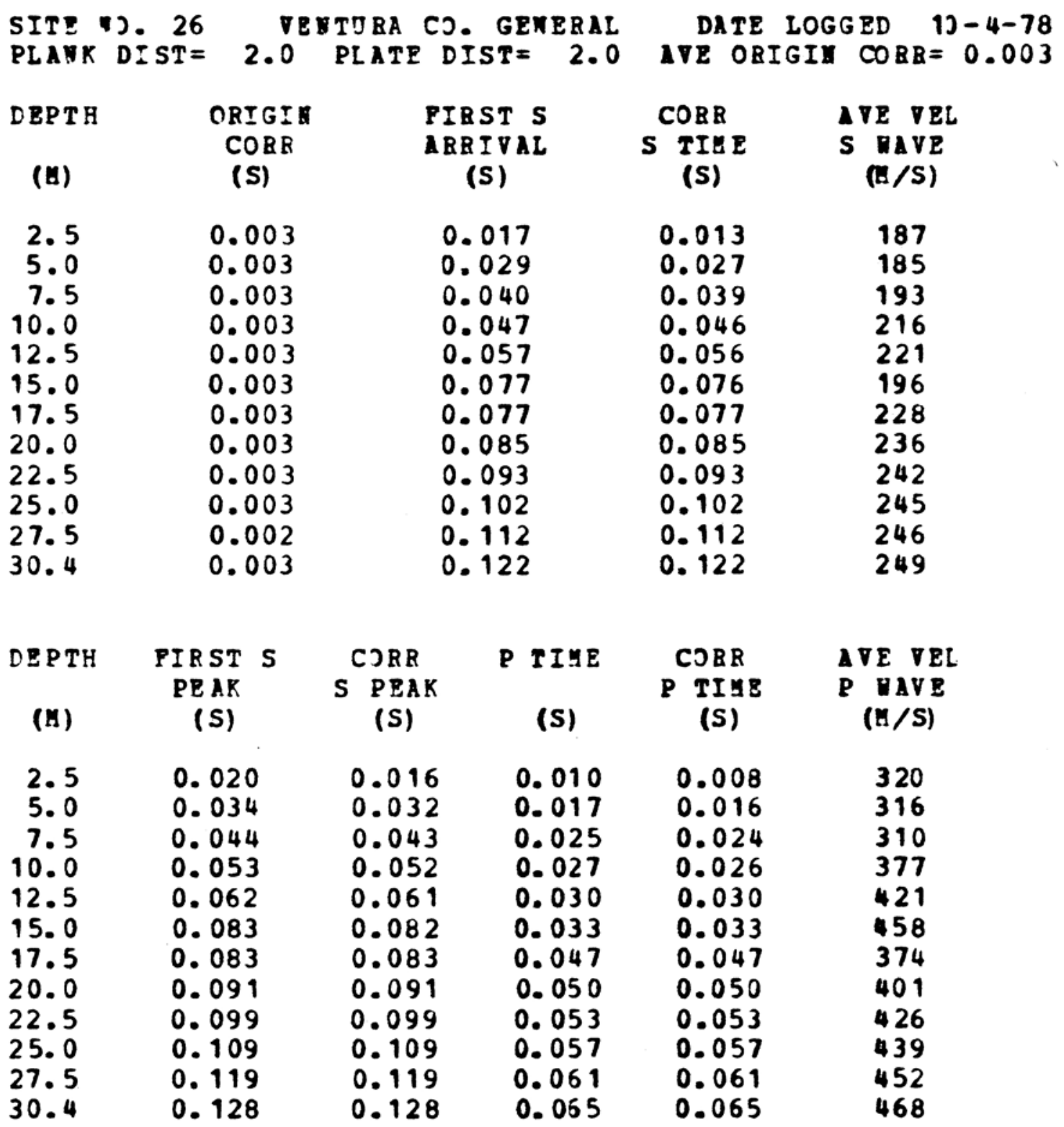


TABLE 27

IHAVEI-TIMES ANL AVZAAGE VEICCITIES

\begin{tabular}{|c|c|c|c|c|c|}
\hline $\begin{array}{l}\text { SITE NO: } 27 \\
\text { ELANK D STT }=\end{array}$ & $\begin{array}{r}27 \\
S T=\end{array}$ & $\begin{array}{l}\text { BAID SAEITARIUE } \\
0 \text { PIAE DTST }\end{array}$ & $\begin{array}{l}\text { RIUE } \\
S I=2.0\end{array}$ & \multicolumn{2}{|c|}{$\begin{array}{l}\text { DATZ ICGGED } 10-5-78 \\
V E \text { JRIGIN CORK }=0.004\end{array}$} \\
\hline $\begin{array}{c}\text { LEレ I: } \\
\text { (M) }\end{array}$ & $\begin{array}{l}\text { UnIGId } \\
C C \operatorname{ma} \\
\text { (S) }\end{array}$ & & $\begin{array}{l}\text { ST S } \\
\text { IVAI } \\
\text { S) }\end{array}$ & $\begin{array}{c}\text { COER } \\
\text { SIY: } \\
\text { (S) }\end{array}$ & $\begin{array}{c}\text { AVE VEL } \\
S \quad \text { AVE } \\
(Y / S)\end{array}$ \\
\hline $\begin{array}{l}2.5 \\
5.0 \\
7.5 \\
10.0 \\
1<.5 \\
15.0 \\
17.5 \\
20.0 \\
22.5 \\
25.0 \\
27.5 \\
29.0\end{array}$ & 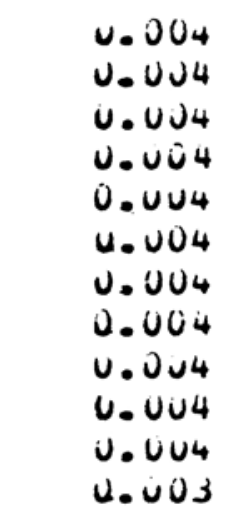 & & $\begin{array}{l}018 \\
026 \\
034 \\
043 \\
053 \\
062 \\
070 \\
077 \\
084 \\
091 \\
098 \\
101\end{array}$ & $\begin{array}{l}0.014 \\
0.024 \\
0.033 \\
0.042 \\
0.052 \\
0.062 \\
0.070 \\
0.077 \\
0.084 \\
0.041 \\
0.098 \\
0.101\end{array}$ & $\begin{array}{l}177 \\
206 \\
227 \\
236 \\
238 \\
243 \\
251 \\
260 \\
260 \\
275 \\
281 \\
287\end{array}$ \\
\hline $\begin{array}{c}\text { DEFTi } \\
\text { (X) }\end{array}$ & $\begin{array}{c}\text { EIRSI } S \\
\text { EEAK } \\
\text { (D) }\end{array}$ & $\begin{array}{l}\text { CUKR } \\
S \text { PEAK } \\
\text { (S) }\end{array}$ & $\begin{array}{c}\text { P TIEE } \\
\text { (S) }\end{array}$ & $\begin{array}{l}\text { CORA } \\
\text { P TIME } \\
\text { (S) }\end{array}$ & $\begin{array}{l}\text { AVE VEL } \\
\text { P WAVE } \\
(H / S)\end{array}$ \\
\hline $\begin{array}{r}2.5 \\
5.0 \\
7.5 \\
10.0 \\
12.5 \\
15.0 \\
17.5 \\
20.0 \\
22.5 \\
25.0 \\
27.5 \\
29.0\end{array}$ & $\begin{array}{l}0.025 \\
0.032 \\
0.040 \\
0.040 \\
0.054 \\
0.008 \\
0.070 \\
0.007 \\
0.044 \\
0.100 \\
0.107 \\
0.110\end{array}$ & $\begin{array}{l}0.020 \\
0.030 \\
0.034 \\
0.047 \\
0.058 \\
0.067 \\
0.076 \\
0.087 \\
0.094 \\
0.100 \\
0.107 \\
0.110\end{array}$ & $\begin{array}{l}0.010 \\
0.012 \\
0.014 \\
0.015 \\
0.017 \\
0.018 \\
0.020 \\
0.021 \\
0.037 \\
0.049 \\
0.052 \\
0.065\end{array}$ & $\begin{array}{l}0.008 \\
0.011 \\
0.014 \\
0.015 \\
0.017 \\
0.018 \\
0.020 \\
0.021 \\
0.037 \\
0.049 \\
0.052 \\
0.005\end{array}$ & $\begin{array}{l}320 \\
448 \\
554 \\
679 \\
744 \\
840 \\
880 \\
957 \\
610 \\
511 \\
530 \\
447\end{array}$ \\
\hline
\end{tabular}


INTERVAL VELUCITIES AND ELASTIC MODULI

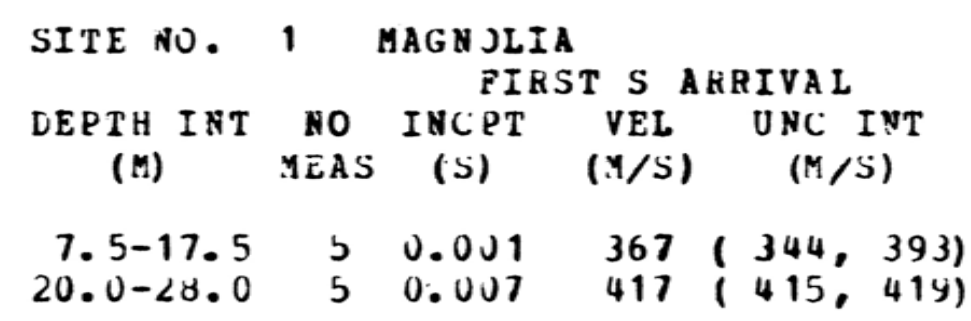

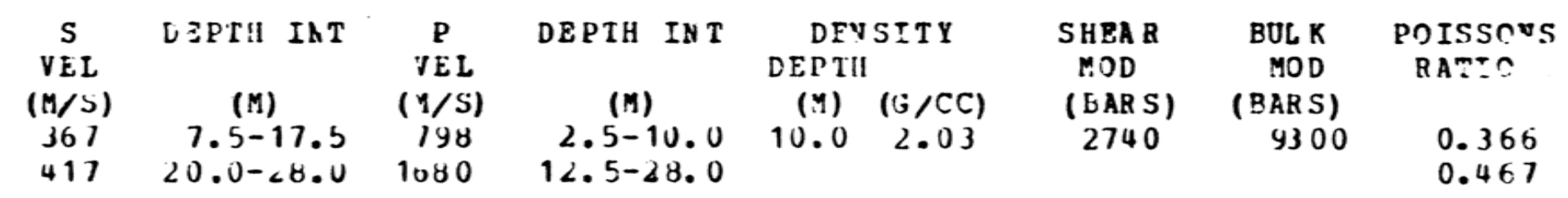


INTERVAL VELUCITIES AND ELASTIC MODULI

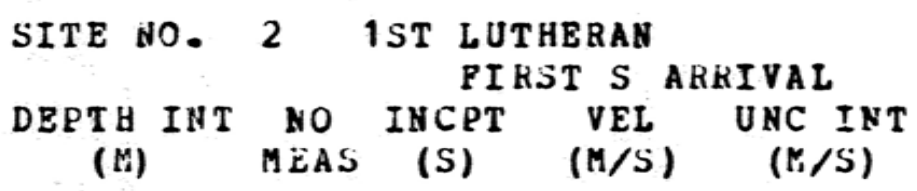

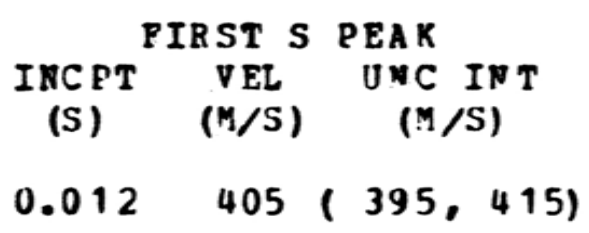

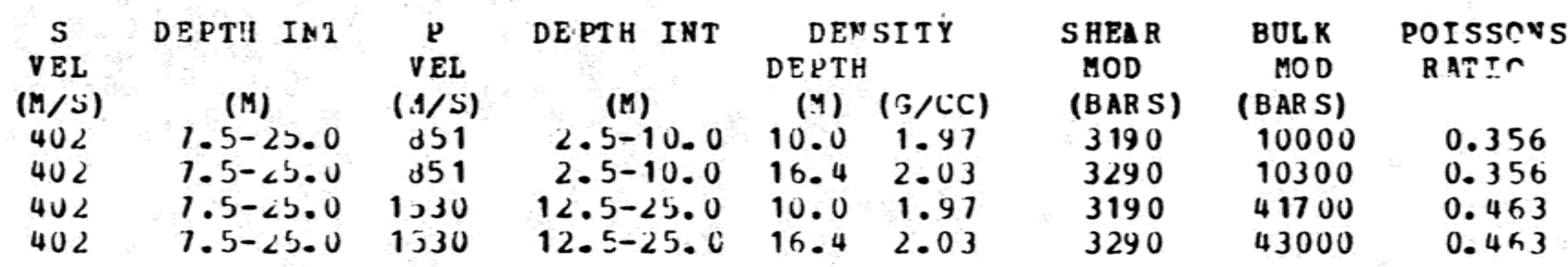


INTEHVAL VELUCITIES AND ELASTIC MODULI

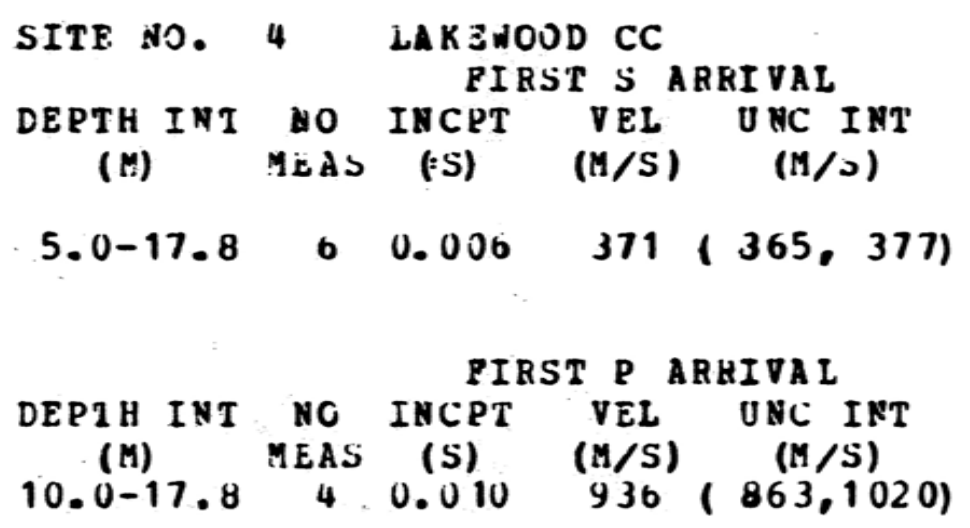

\begin{tabular}{|c|c|c|c|c|c|c|c|c|}
\hline $\begin{array}{c}S \\
V E L \\
(M / S) \\
371 \\
371\end{array}$ & $\begin{array}{c}\text { DЕPTH IMT } \\
\text { (M) } \\
5.0-17.8 \\
5.0-17.6\end{array}$ & $\begin{array}{c}P \\
V E L \\
(Y / S) \\
936 \\
930\end{array}$ & $\begin{array}{l}\text { DEPTH INT } \\
\text { (H) } \\
10.0-17.8 \\
10.0-17.8\end{array}$ & $\begin{array}{c}\text { DEF } \\
\text { DEPTH } \\
\text { (M) } \\
9.1 \\
15.2\end{array}$ & $\begin{array}{l}\text { SITY } \\
\text { (G/CC) } \\
2.03 \\
2.04\end{array}$ & $\begin{array}{c}\text { SHEAR } \\
\text { MOD } \\
\text { (BARS) } \\
2800 \\
2820\end{array}$ & $\begin{array}{c}\text { BUL K } \\
\text { MOD } \\
\text { (BARS) } \\
14100 \\
14100\end{array}$ & $\begin{array}{l}\text { POISSCNS } \\
\text { RATTO } \\
0.407 \\
0.407\end{array}$ \\
\hline
\end{tabular}


ITTERVAL VELOCITIBS AMD ELASTIC MODOLI

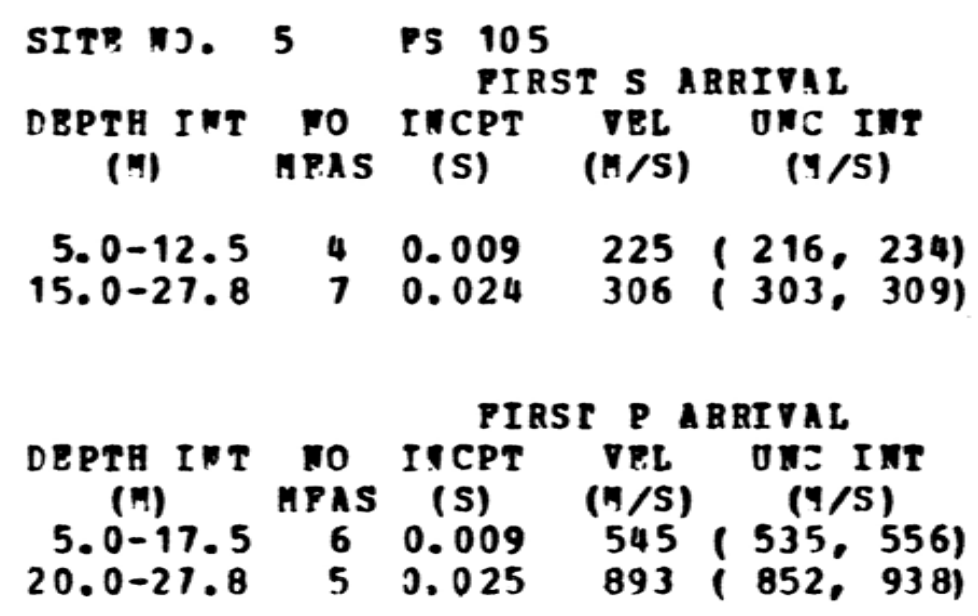

\begin{tabular}{|c|c|c|c|c|c|c|c|c|}
\hline $\begin{array}{c}S \\
V E L \\
(P / S) \\
225 \\
306\end{array}$ & $\begin{array}{c}\text { DEPTH INT } \\
\text { (M) } \\
5.0-12.5 \\
15.0-27.8\end{array}$ & $\begin{array}{c}P \\
V P L \\
(1 / S / S) \\
545 \\
893\end{array}$ & $\begin{array}{c}\text { DEPTH INT } \\
\text { (A) } \\
5.0-17.5 \\
20.0-27.8\end{array}$ & $\begin{array}{c}\text { DEN } \\
\text { DEPTH } \\
\text { (I) } \\
9.1 \\
21.8\end{array}$ & $\begin{array}{l}\text { SITI } \\
\text { (G/CC) } \\
1.90 \\
2.03\end{array}$ & $\begin{array}{c}\text { SABAB } \\
\text { HOD } \\
\text { (BARS) } \\
962 \\
1910\end{array}$ & $\begin{array}{r}\text { BOGK } \\
\text { HOD } \\
\text { (BABS) } \\
4370 \\
13700\end{array}$ & $\begin{array}{l}\text { POISSOES } \\
\text { RATIO } \\
0.397 \\
0.433\end{array}$ \\
\hline
\end{tabular}


INTERVAL VELOCITIES AND BLASTIC MODOLI

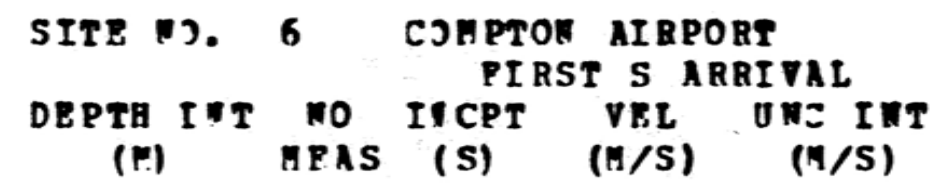

$2.5-15.0 \quad 50.001 \quad 277(275,279)$

के

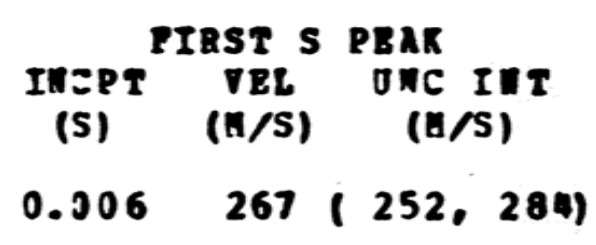

PIRST P ARRIVAL

DEPTH IBT DO INCPT VEL ONE I HT

(II) HPAS (S) (H/S) (H/S)

$5.0-15.0 \quad 5 \quad 0.005 \quad 1360(1250,1500)$

\begin{tabular}{|c|c|c|c|c|c|c|c|}
\hline $\begin{array}{c}S \\
\nabla E L \\
(M / S) \\
277\end{array}$ & $\begin{array}{l}\text { DEPTH IFT } \\
\text { (H) } \\
2.5-15.0\end{array}$ & $\begin{array}{l}P \\
V \nabla L \\
(H / S) \\
1360\end{array}$ & $\begin{array}{l}\text { DEPTH INT } \\
\text { (A) } \\
5.0-15.0\end{array}$ & $\begin{array}{l}\text { DERSTTI } \\
\text { DEPTH } \\
\text { (M) }(G / C C) \\
6.1 \quad 1.90\end{array}$ & $\begin{array}{c}\text { SBBA } \\
\text { HOD } \\
\text { (BARS) } \\
1460\end{array}$ & $\begin{array}{c}\text { BO: K } \\
\text { HOD } \\
\text { (BARS) } \\
33400\end{array}$ & $\begin{array}{l}\text { POISSOIS } \\
\text { RATIO } \\
0.478\end{array}$ \\
\hline
\end{tabular}




\section{INTEBVAL VELOCITIES AND ELASTIC MODULI}

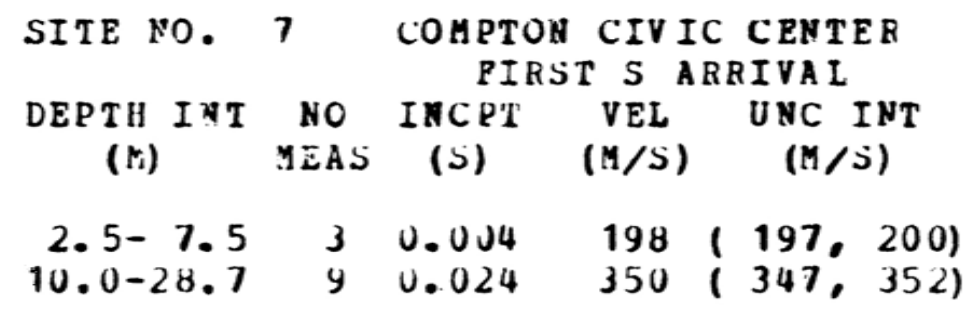

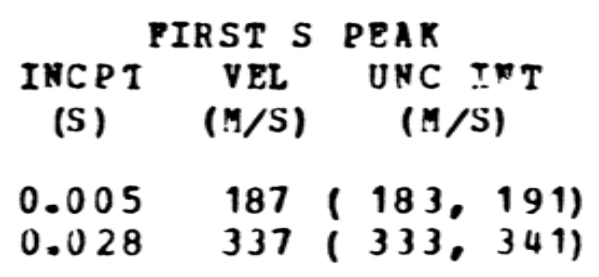

\begin{tabular}{ccccc} 
& & \multicolumn{3}{c}{ PIRST P ARRIVAL } \\
DEPTH INT & NO & INCPT & VEL & UNC INT \\
(M) & MEAS & (S) & (M/S) & (M/S) \\
$2.5-7.5$ & 3 & 0.002 & 366 & $(330,412)$ \\
$7.5-17.5$ & 5 & 0.011 & 652 & $(637,669)$ \\
$17.5-28.7$ & 0 & 0.027 & 1060 & $(1570,1780)$
\end{tabular}

\begin{tabular}{|c|c|c|c|c|c|c|c|c|}
\hline$\underset{v E L}{S}$ & DEPTH ILI & $\underset{i \Xi L}{v}$ & DEPTH IN T & $\begin{array}{r}D E \\
D E P T\end{array}$ & SITY & $\begin{array}{c}\text { SHEAR } \\
\text { MOD }\end{array}$ & $\begin{array}{r}\text { BUL K } \\
\text { K כ D }\end{array}$ & $\begin{array}{c}\text { POISSONS } \\
\text { RATT }\end{array}$ \\
\hline$(M / S)$ & (M) & $(M / S)$ & (M) & (M) & $(\mathrm{G} / \mathrm{CC})$ & (BARS) & (BARS) & \\
\hline $198^{\circ}$ & $2.5-7.5$ & 306 & $2.5-7.5$ & 2.7 & 1.63 & 645 & 1330 & 0.292 \\
\hline 350 & $10.0-<0.7$ & ob2 & $7.5-17.5$ & 15.2 & 2.00 & 2450 & 5260 & 0.298 \\
\hline 350 & $10.0-<0.1$ & 652 & 5 & 21.8 & 2.07 & 2540 & 5440 & 0.298 \\
\hline 350 & $10.0-<0.7$ & 1660 & $5-28.7$ & 15.2 & 2.00 & 2450 & 52100 & 0.477 \\
\hline 350 & $0-20.7$ & 1660 & $5-28.7$ & 21.8 & 2.07 & 2540 & 54000 & 0.477 \\
\hline
\end{tabular}


INTERVAL VELUCITIES AND ELASTIC MODULI

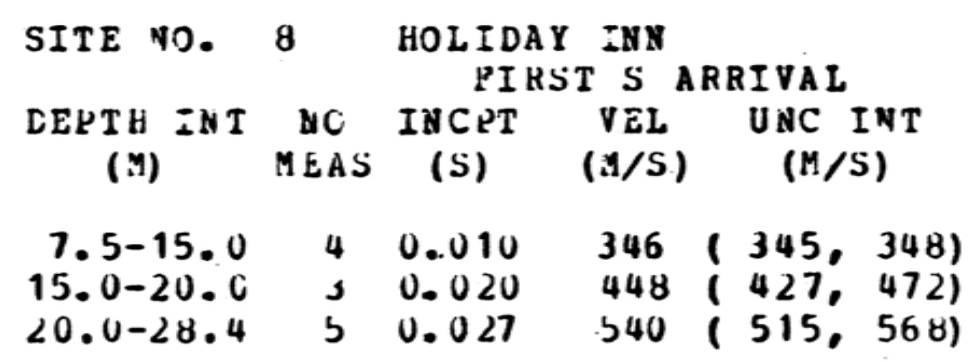

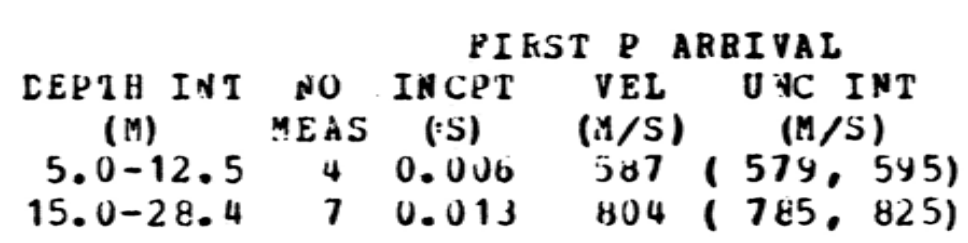

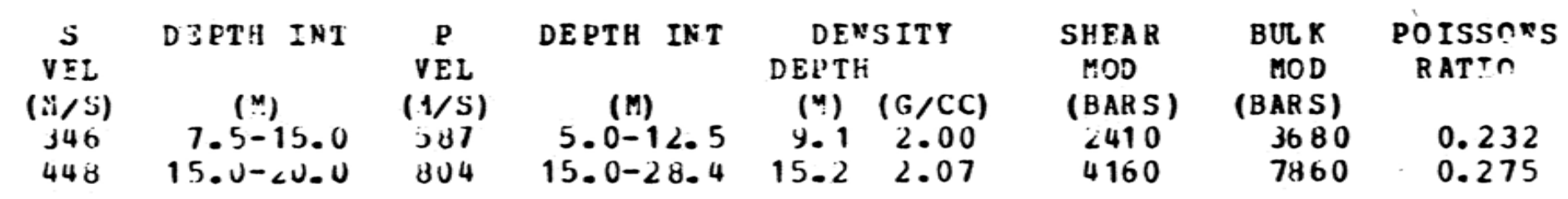


INTERVAL VELOCITIES AND ELASTIC MODULI

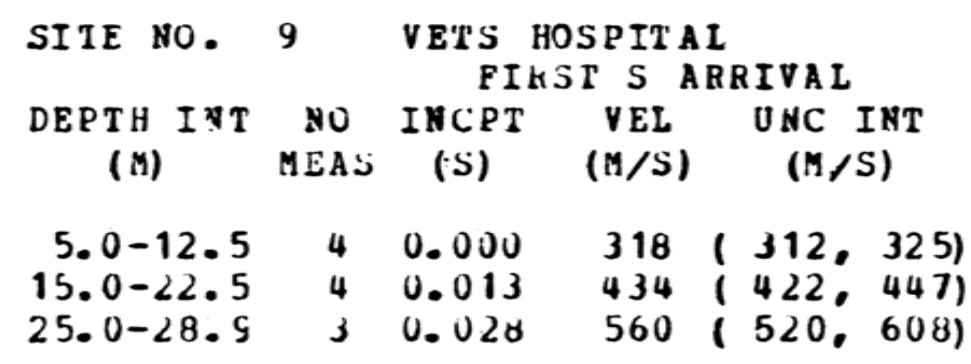

\begin{tabular}{|c|c|c|}
\hline \multicolumn{3}{|c|}{ PIRST $S$ PEAK } \\
\hline $\begin{array}{l}\text { INC P T } \\
\text { (S) }\end{array}$ & $\begin{array}{l}\mathrm{VBL} \\
(n / S)\end{array}$ & $\begin{array}{c}\text { ONC INT } \\
(M / S)\end{array}$ \\
\hline $\begin{array}{l}0.005 \\
0.018 \\
0.034\end{array}$ & $\begin{array}{l}315 \\
426 \\
560\end{array}$ & $\begin{array}{l}(308,321) \\
(398,458) \\
(519,608)\end{array}$ \\
\hline
\end{tabular}

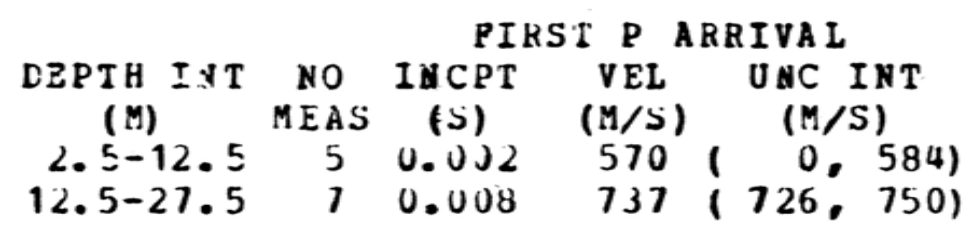

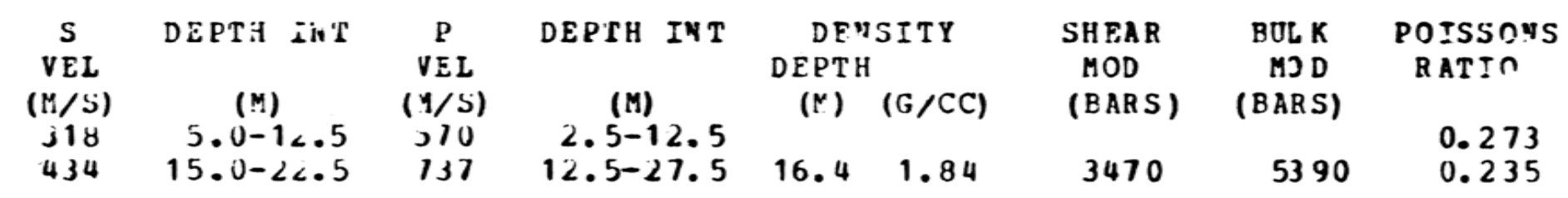


INTERVAL VELCCITIES AND ELASTIC RODULI

SITE NO. 11 KATELLA SCHOCL
DEPTH INT NO INCET VEL UNC INT
(M) MEAS (S) (M/S) (M/S)

$5.0-19.770 .014 \quad 830(795,868)$

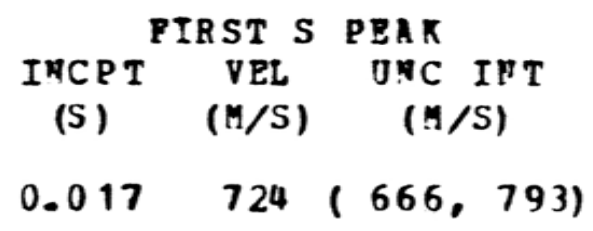

FIRST $P$ ARRIVAL

DEPTH INT NO INCPT VEL UNC INT

$\begin{array}{llll}\text { (M) } M E A S \quad(S) \quad(M / S) & (M / S)\end{array}$

$2.5-15.0$ 6 $0.0051290 \quad(1260.1330)$

\begin{tabular}{|c|c|c|c|c|c|c|c|}
\hline $\begin{array}{c}S \\
V E L \\
(M / S) \\
030\end{array}$ & $\begin{array}{c}\text { DEFTH INT } \\
\text { (Y) } \\
5.0-1 Y .7\end{array}$ & $\begin{array}{c}P \\
V E L \\
(9 / S) \\
1290\end{array}$ & $\begin{array}{l}\text { DEPTH INT } \\
\text { (M) } \\
2.5-15.0\end{array}$ & $\begin{array}{l}\text { DENSITY } \\
\text { DEPTH } \\
(\mathrm{M}) \quad(\mathrm{F} / \mathrm{CC})\end{array}$ & $\begin{array}{l}\text { SHEAR } \\
\text { MOD } \\
\text { (BARS) }\end{array}$ & $\begin{array}{c}\text { BUL K } \\
\text { MJ D } \\
\text { (BARS) }\end{array}$ & $\begin{array}{c}\text { POISSCNS } \\
\text { RATZ? } \\
0.146\end{array}$ \\
\hline
\end{tabular}


IUTEAVAL VELULITIES AaL ELASTIC RODULI

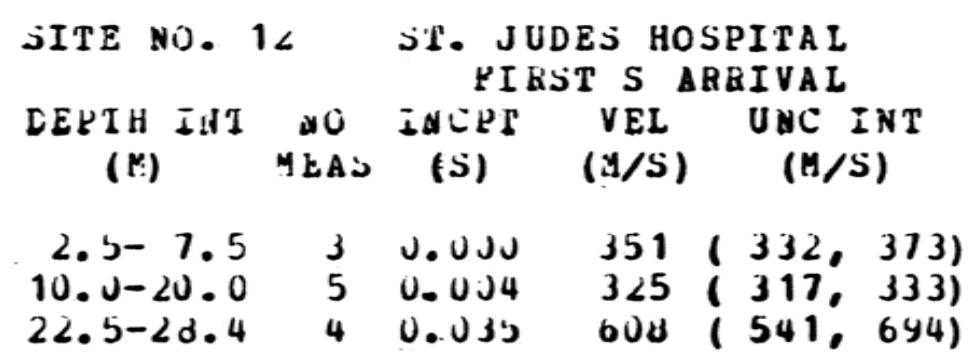

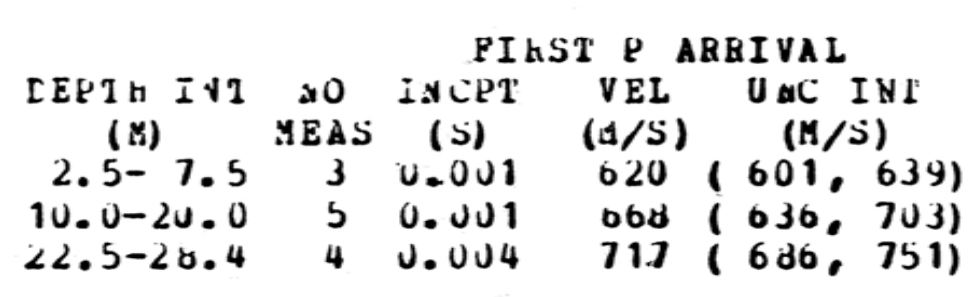

\begin{tabular}{|c|c|c|c|c|c|c|c|c|}
\hline $\begin{array}{c}S \\
V E L \\
(E / S) \\
351 \\
32 b\end{array}$ & $\begin{array}{c}\text { DEPTH IAT } \\
\text { (M) } \\
\begin{array}{c}2.5-7.5 \\
10 . U-\angle U . U\end{array}\end{array}$ & $\begin{array}{c}P \\
V E L \\
(1 / S) \\
0<0 \\
608\end{array}$ & $\begin{array}{l}\text { DERTH INT } \\
\text { (M) } \\
2.5-7.5 \\
10.0-20.0\end{array}$ & $\begin{array}{r}\text { DEI } \\
\text { DLPTI } \\
(M) \\
6.1 \\
12.1\end{array}$ & $\begin{array}{c}(\mathrm{G} / \mathrm{CC}) \\
2.03 \\
2.03\end{array}$ & $\begin{array}{l}\text { SHEA R } \\
\text { MOD } \\
\text { (BAR S) } \\
2510 \\
2150\end{array}$ & $\begin{array}{r}\text { BULK } \\
\text { MOD } \\
\text { (BAR S) } \\
4460 \\
6200\end{array}$ & $\begin{array}{l}\text { POISSONS } \\
\text { RATIO }\end{array}$ \\
\hline
\end{tabular}


INTERVAL VELOCITIES AND ELASTIC MODULI

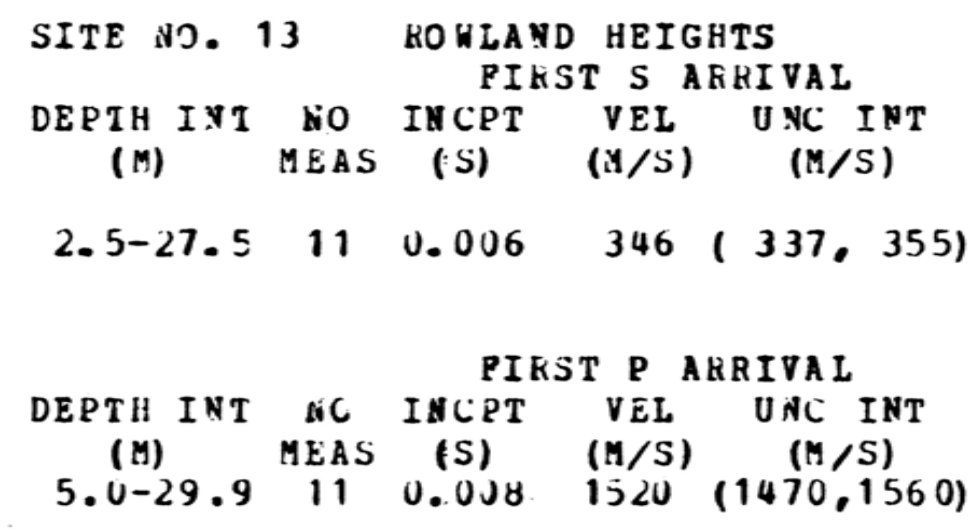

PIKST P ARRIVAL

$\begin{array}{ccccc}\text { DEPTH INT } & \text { IC } & \text { INCPT } & \text { VEL } & \text { UNC INT } \\ \text { (M) } & \text { MEAS } & \text { (S) } & \text { (M/S) } & \text { (M/S) } \\ 5 . U-29.9 & 11 & \text { U.OJY } & 1520 & (1470,1560)\end{array}$

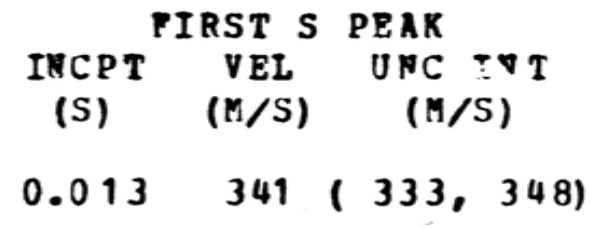

$0.013341(333,348)$

\begin{tabular}{|c|c|c|c|c|c|c|c|c|}
\hline$\underset{\substack{S \\
(M / S)}}{S}$ & DEPTH INT & $\underset{V E L}{P}$ & DEPTH INT & $\begin{array}{r}\text { DE } \\
\text { DEPT }\end{array}$ & ISITY & $\begin{array}{l}\text { SHEA R } \\
\text { MOD }\end{array}$ & $\begin{array}{r}\text { BUL K } \\
\text { MOD }\end{array}$ & $\begin{array}{l}\text { POISSN"S } \\
\text { RATID }\end{array}$ \\
\hline$(M / S)$ & (Y) & $(y / S)$ & (I) & (Y) & $(G / C C)$ & (BAR S) & (BARS) & \\
\hline 346 & $2.5-27.5$ & 1320 & $5 \cdot 0-29 \cdot 9$ & 3.0 & 2.10 & 2520 & 45000 & 0.473 \\
\hline 346 & $2.5-<7.5$ & 1520 & $5.0-29 \cdot 9$ & 6.1 & 1.97 & 2360 & 42200 & 0.473 \\
\hline 346 & $2.5-<1.5$ & 1020 & $5.0-29.9$ & 11.5 & 2.11 & 2530 & 45200 & 0.473 \\
\hline 346 & $2.5-27.5$ & 1520 & $5.00-2 y .9$ & 18.8 & 1.95 & 2340 & 41800 & 0.473 \\
\hline
\end{tabular}


INTERVAL VELOCITIBS AND ELASTIC MODOLI

SITE คว. 14 EL HORE COORT HOOSB

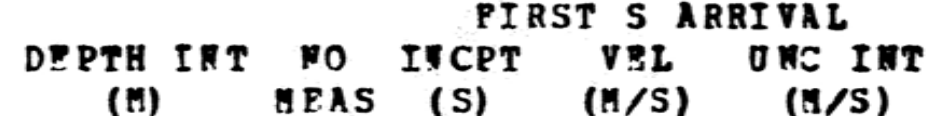

$\begin{array}{rlll}7.4-15.0 & 0.010 & 273 & (265,282)\end{array}$

$22.5-28.240 .035443(408,484)$

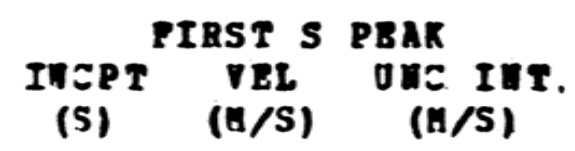

$0.015272(263,281)$

$\vec{D}$

\begin{tabular}{|c|c|c|c|c|}
\hline & & & & \\
\hline $\begin{array}{l}\text { DEPTH INT } \\
\text { (M) } \\
5.0-12.5\end{array}$ & $\begin{array}{c}\text { FO } \\
\text { GEAS } \\
4\end{array}$ & $\begin{array}{c}\text { INCPT } \\
\text { (S) } \\
0.012 \\
0.030\end{array}$ & $\begin{array}{l}V E L \\
(H / S) \\
1140 \\
1180\end{array}$ & $\begin{array}{c}\text { ONC INT } \\
(H / S) \\
(990.1350) \\
(1150.1220)\end{array}$ \\
\hline
\end{tabular}

\begin{tabular}{|c|c|c|c|c|c|c|c|}
\hline $\begin{array}{c}S \\
\nabla E L \\
(K / S) \\
273 \\
443\end{array}$ & $\begin{array}{c}\text { DEPTH IHT } \\
\text { (A) } \\
7.4-15.0 \\
22.5-28.2\end{array}$ & $\begin{array}{c}P \\
\nabla F L \\
(N / S) \\
1140 \\
1180\end{array}$ & $\begin{array}{c}\text { DEPTH IAT } \\
\text { (A) } \\
5.0-12.5 \\
20.0-28.2\end{array}$ & $\begin{array}{l}\text { DEHSITY } \\
\text { DEPTH } \\
\text { (H) }(G / C C)\end{array}$ & $\begin{array}{c}\text { SHBAR } \\
\text { HOD } \\
\text { (BARS) }\end{array}$ & $\begin{array}{c}\text { BULK } \\
\text { MJD } \\
\text { (BARS) }\end{array}$ & $\begin{array}{l}\text { POISSOIS } \\
\text { RATIO } \\
0.470 \\
0.418\end{array}$ \\
\hline
\end{tabular}


TABLE 43

INTERVAL VELOCITIES AND ZLASTIC MODULI

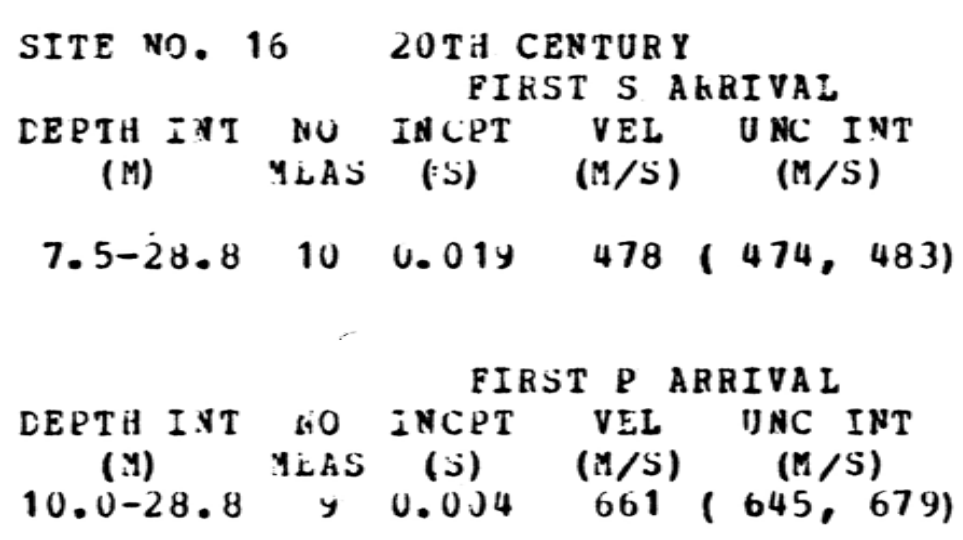

\begin{tabular}{|c|c|c|c|c|c|c|c|}
\hline$\underset{\substack{\text { VEL } \\
(M / S)}}{S}$ & $\begin{array}{c}\text { DEPTH INT } \\
\text { (id) }\end{array}$ & $\begin{array}{c}\underset{v}{V} \mathrm{~L} \\
(1 / \mathrm{S})\end{array}$ & $\begin{array}{c}\text { DEPTH IN T } \\
\text { (M) }\end{array}$ & $\begin{array}{l}\text { DEN SITY } \\
\text { DEPTH } \\
\text { (Y) (G/CC) }\end{array}$ & $\begin{array}{c}\text { SHEA R } \\
\text { MOD } \\
\text { (BARS) }\end{array}$ & $\begin{array}{c}\text { BULK } \\
\text { MOD } \\
\text { (BARS) }\end{array}$ & $\begin{array}{l}\text { POTSSONS } \\
\text { RATT }\end{array}$ \\
\hline
\end{tabular}


INTERVAL VELUCLIIES AND ELASTIC MODULI

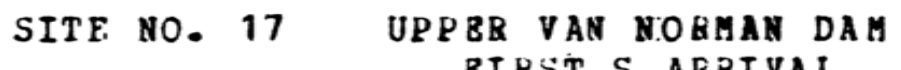

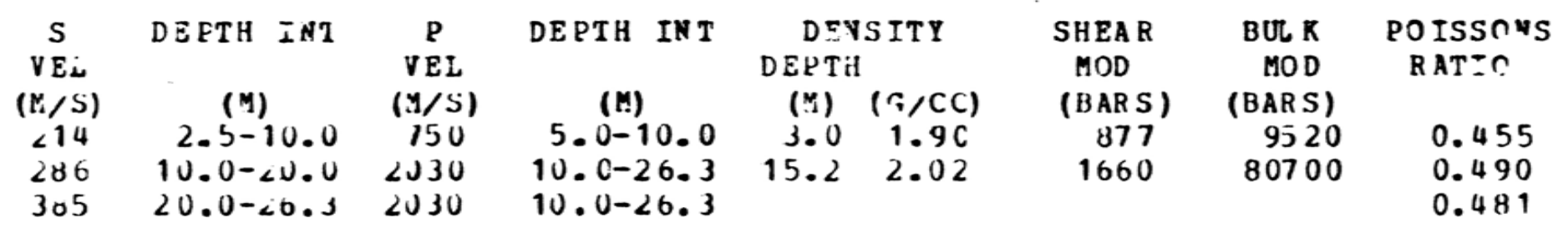


INTEKVAL VELCLITIES AND ELASTIC MODULI SITE NO. 18 PACOIMA MEMOETAL HOSP. CEPTH IVT MO INCPT
(M) MEL

$\begin{array}{rllll}2.5-7.5 & 3 & 0.011 & 201 \\ 1.5-17.5 & 5 & 0.027 & 352 & (398,204) \\ 17.5-29.7 & 6 & 0.044 & 541(531.550)\end{array}$

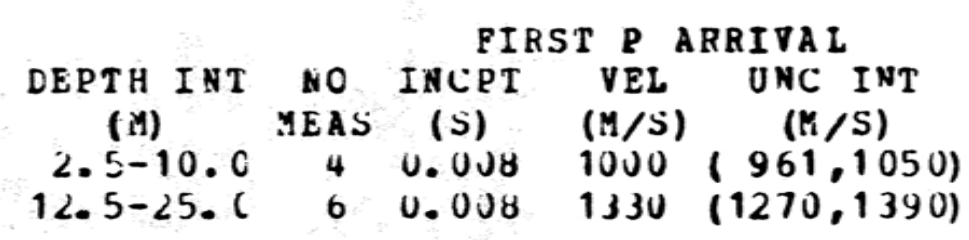

\begin{tabular}{|c|c|c|c|c|c|c|c|c|}
\hline $\begin{array}{l}S \\
V E L \\
(M / S) \\
2 U 1 \\
352 \\
352 \\
541\end{array}$ & $\begin{array}{c}\text { DEPTH IAI } \\
\text { (M) } \\
2.5-7.5 \\
7.5-17.5 \\
1.5-17.5 \\
17.5-29.7\end{array}$ & $\begin{array}{l}P \\
V E L \\
(y / S) \\
1000 \\
1330 \\
1330 \\
1327\end{array}$ & $\begin{array}{c}\text { DEPTH INT } \\
\text { (M) } \\
2.5-10.0 \\
12.5-25.0 \\
12.5-25.0 \\
12.5-25.0\end{array}$ & $\begin{array}{r}\text { DF } \\
\text { DEPT } \\
(11) \\
3.0 \\
9.1 \\
15.1 \\
21.8\end{array}$ & $\begin{array}{l}\text { STTY } \\
\text { (G/CC) } \\
1.90 \\
2.03 \\
2.04 \\
2.12\end{array}$ & $\begin{array}{c}\text { SHEAR } \\
\text { MOD } \\
\text { (BAR S) } \\
770 \\
2530 \\
2540 \\
6210\end{array}$ & $\begin{array}{c}\text { BOL R } \\
\text { MOD } \\
\text { (BAR S) } \\
18000 \\
32400 \\
32500 \\
29100\end{array}$ & $\begin{array}{l}0.479 \\
0.462 \\
0.462 \\
0.400\end{array}$ \\
\hline
\end{tabular}




\section{INTERVAL VELCLITIES AND ELASTIC MODULI}

\section{SITE NO. 19 SYLMAR H.S.}

FIRST $S$ ARBIVA.T

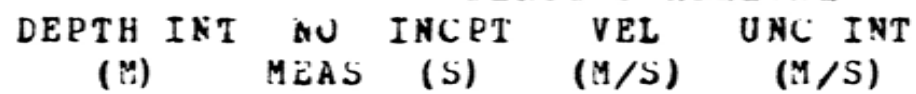

$\begin{array}{rrrrr}2.5-10.0 & 4 & 0.006 & 311 & (308,314) \\ 12.5-29.0 & 0 & 0.015 & 494(484,505)\end{array}$

ज़

\begin{tabular}{|c|c|c|c|c|c|c|c|c|}
\hline $\begin{array}{c}S \\
V E L\end{array}$ & DEPTH INT & $\underset{\text { VEL }}{P}$ & DEPTH INT & $\begin{array}{r}\text { DE } \\
\text { DEPT }\end{array}$ & SITY & $\begin{array}{c}\text { SHEA R } \\
\text { MOD }\end{array}$ & $\begin{array}{r}\text { BULK } \\
\text { MOD }\end{array}$ & $\begin{array}{c}\text { POISSONS } \\
\text { RAT? }\end{array}$ \\
\hline$(m / S)$ & $(y)$ & $(1 / j)$ & (M) & (y) & $(\mathrm{G} / \mathrm{CC})$ & (EAR S) & (BARS) & \\
\hline 311 & $2.5-10.0$ & 522 & $2.5-12.5$ & y. 1 & 2.16 & 2090 & 3110 & 0.225 \\
\hline 494 & $12.5-<y . U$ & yy & $15.0-29.0$ & & & & & 0.190 \\
\hline
\end{tabular}


INTERVAL VELOCITIES AND ELASTIC MODULI SITE NO. 20 MISIION HIIIS P.O. CEPTI INT NO INCPT VEL UNC INT

(M) MEAS (S) (M/S) (M/S)

$\begin{array}{rllll}2.5-15.0 & 6 & 0.008 & 420 & (413,427) \\ 17.5-29.3 & 6 & 0.021 & 615 & (595.637)\end{array}$

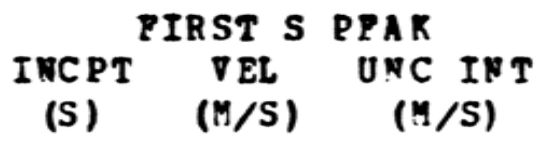

$0.013415(408,423)$

$0.026614(594,636)$

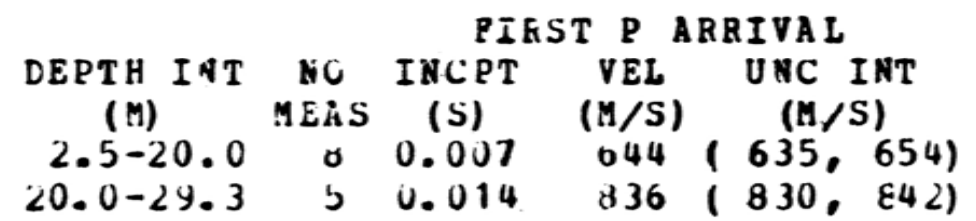

\begin{tabular}{|c|c|c|c|c|c|c|c|c|}
\hline$\underset{V E L}{S}$ & DEPTH INT & $\underset{\text { VEI }}{\mathbf{P}}$ & DEPTH INT & $\begin{array}{r}\text { DEN } \\
\text { DEPTH }\end{array}$ & SI TY & $\begin{array}{c}S \text { HEAR } \\
\text { MOD }\end{array}$ & $\begin{array}{r}\text { BULK } \\
\text { MCD }\end{array}$ & $\begin{array}{l}\text { POISSCVS } \\
\text { RATIn }\end{array}$ \\
\hline $1 / 5)$ & & $(M / S)$ & () & (M) & $(G / C$ & (BARS) & ( BAR S) & \\
\hline $\begin{array}{l}420 \\
420\end{array}$ & $\begin{array}{l}2.5-15.0 \\
2.5-15.0\end{array}$ & $\begin{array}{l}044 \\
644\end{array}$ & $\begin{array}{l}2.5-20.0 \\
2.5-20.0\end{array}$ & $\begin{array}{l}3.0 \\
6.1\end{array}$ & & & $\begin{array}{l}3480 \\
3570\end{array}$ & \\
\hline 420 & $2.5-15.0$ & 644 & $2.5-20.0$ & 12.0 & 2.03 & 3590 & 3660 & 0.130 \\
\hline
\end{tabular}


INTERVAL VELOCITIES AND ELASTIC MODULI

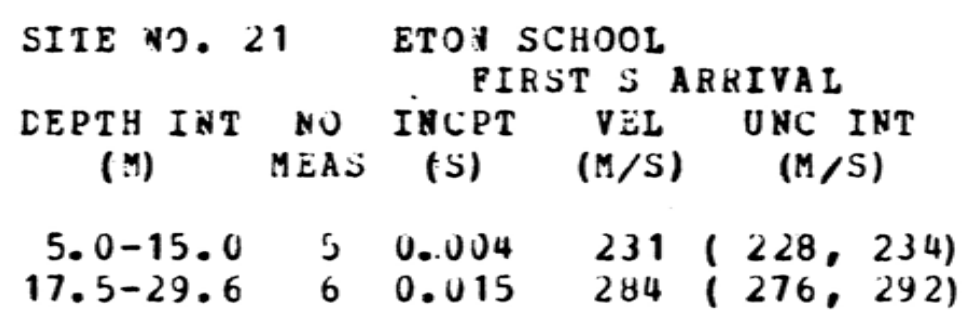

PIRST P AERIVAL

\begin{tabular}{|c|c|c|}
\hline \multicolumn{3}{|c|}{ FIRST S PEAK } \\
\hline $\begin{array}{l}\text { INCP I } \\
\text { (S) }\end{array}$ & $\begin{array}{l}\text { VEL } \\
(M / S)\end{array}$ & $\begin{array}{c}\text { UNC INT } \\
(M / S)\end{array}$ \\
\hline $\begin{array}{l}0.0111 \\
0.0220\end{array}$ & $\begin{array}{l}233 \\
274\end{array}$ & $\begin{array}{l}(226,239) \\
(267,282)\end{array}$ \\
\hline
\end{tabular}

DEPTH INT NO INCPI VEL UNC INT

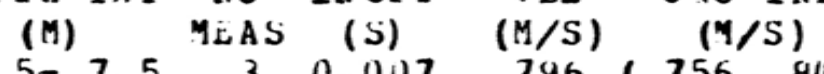

$2.5-7.530 .007796(756,841)$

$10.0-29.6$ 9 $0.016 \quad 1370 \quad(1820,1930)$

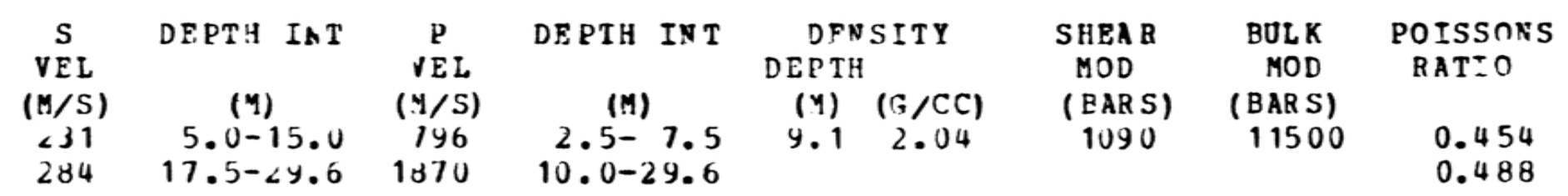


INTERVAL VELOCITIES AND ELASTIC MODULI SITE HO. 22 CAMARILLO STATE HOSP.

\begin{tabular}{ccccc} 
& & \multicolumn{3}{c}{ FIRST P ARRIVAL } \\
DEPTH INT & NU & INCPT & VEL & UNC INT \\
(M) & MEAS & (S) & (M/S) & (M/S) \\
$5.0-12.5$ & 4 & 0.011 & 1140 & $(103 C, 1290)$ \\
$17.5-29.8$ & 6 & 0.031 & 1310 & $(1260,1360)$
\end{tabular}

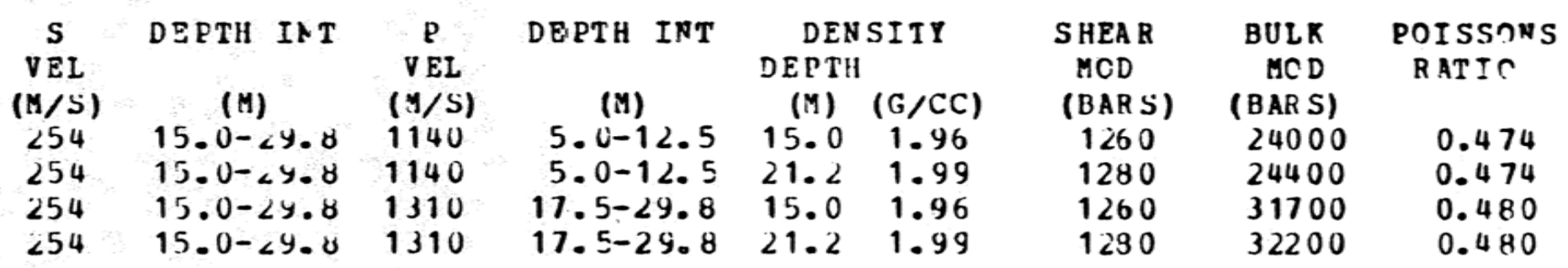
DEPTH INT NO INCPT VEL UNC INT (I) $Y$ IEAS $(S) \quad(M / S) \quad(M / S)$ $15.0-29.870 .002 \quad 254(250,257)$

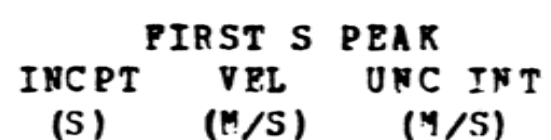


TNTPRVAL VELOCITIBS AND ELASTIC MODOLI SITE W0. 23 PACIFIC MISSLE PIRST S ARRIVAL

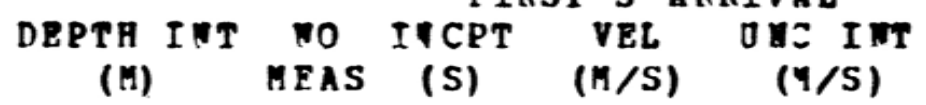

$7.5-17.5 \quad 5 \quad 0.010 \quad 220(217,223)$ $17.5-29.460 .023 \quad 262$ ( 258, 267)

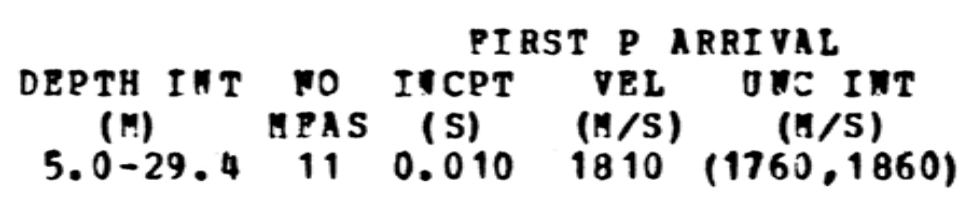

\begin{tabular}{|c|c|c|c|c|c|c|c|c|}
\hline $\begin{array}{c}S \\
\nabla P L \\
(m / S) \\
220 \\
220 \\
262\end{array}$ & $\begin{array}{c}\text { (1) } \\
7.5-17.5 \\
7.5-17.5 \\
17.5-29.4\end{array}$ & $\begin{array}{c}P \\
V E L \\
(M / S) \\
1810 \\
1810 \\
1810\end{array}$ & $\begin{array}{c}\text { (m) } \\
5.0-29.4 \\
5.0-29.4 \\
5.0-29.4\end{array}$ & $\begin{array}{c}\text { DEE } \\
\text { DEPTH } \\
\text { (A) } \\
9.1 \\
15.1 \\
21.2\end{array}$ & $\begin{array}{c}(G / C C) \\
1.91 \\
1.92 \\
1.98\end{array}$ & $\begin{array}{c}\text { SHEA R } \\
\text { MOD } \\
\text { (BAR S) } \\
929 \\
934 \\
1370\end{array}$ & $\begin{array}{c}\text { BOLK } \\
\text { MOD } \\
\text { (BARS) } \\
61200 \\
61600 \\
62900\end{array}$ & $\begin{array}{l}\text { POISSONS } \\
\text { BATIO }\end{array}$ \\
\hline
\end{tabular}


INTERVAL VELGCITIES AND ELASTIC MODULT SITE NO. 24 VENTURA CO. AIRPORT LEPTH INT WO INCPT VEL UNC INT

(1) YEAS (S) (M/S) (M/S)

$\begin{array}{rllll}2.5-7.5 & \text { I } & 0.003 & 177 & (166,189) \\ 10.0-27.5 & 8 & 0.017 & 250 & (248,251)\end{array}$

$$
\text { FIKST P ARRIVAL }
$$

CEPTH INT NO INCPT VEL UNC INT

(N) MEAS $($ S) $(M / S) \quad(M / S)$

$5.0-28.9110 .014 \quad 1130 \quad(1680.1780)$

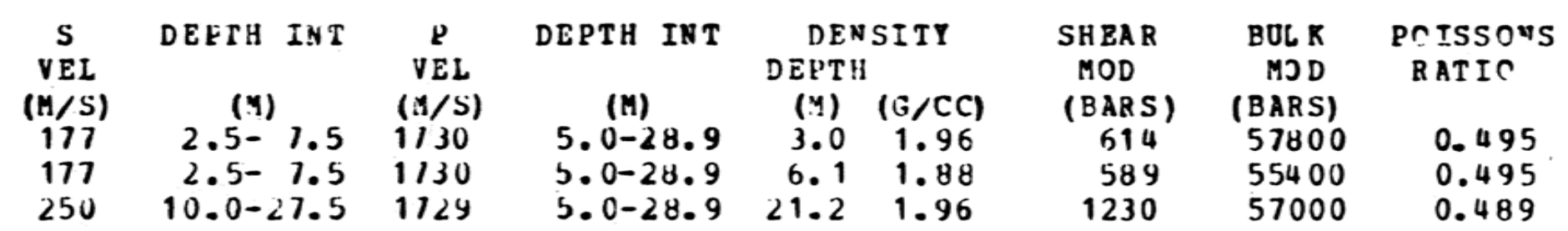

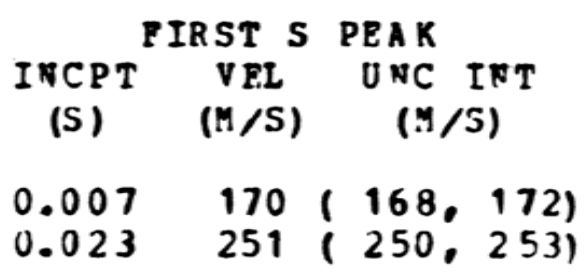

0.489 
TQTERVAL VELOCITIES AmD ELASTIC MODOLI

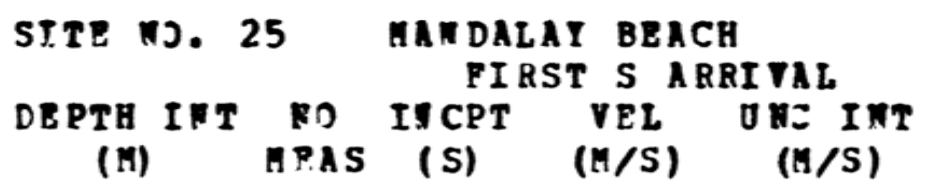

\begin{tabular}{|c|c|c|c|c|c|c|c|c|}
\hline $\begin{array}{l}S \\
\nabla B L \\
(1 / S) \\
242 \\
242 \\
354\end{array}$ & $\begin{array}{c}\text { DEPTH IDT } \\
\text { (H) } \\
5.0-20.0 \\
5.0-20.0 \\
22.5-29.5\end{array}$ & $\begin{array}{c}P \\
V P L \\
(11 / S) \\
1410 \\
1410 \\
1410\end{array}$ & $\begin{array}{c}\text { DBPTH IBT } \\
\text { (I) } \\
5.0-27.5 \\
5.0-27.5 \\
5.0-27.5\end{array}$ & $\begin{array}{c}\text { DER } \\
\text { DEPTH } \\
\text { (H) } \\
9.1 \\
15.1\end{array}$ & $\begin{array}{l}\text { SITY } \\
(G / C G) \\
1.86 \\
1.98\end{array}$ & $\begin{array}{c}\text { SHEAR } \\
\text { MOD } \\
\text { (BARS) } \\
1090 \\
1160\end{array}$ & $\begin{array}{r}\text { BOLK } \\
\text { MOD } \\
\text { (BARS) } \\
35400 \\
37700\end{array}$ & $\begin{array}{l}\text { POISSOYS } \\
\text { RATIO } \\
0.485 \\
0.485 \\
0.466\end{array}$ \\
\hline
\end{tabular}




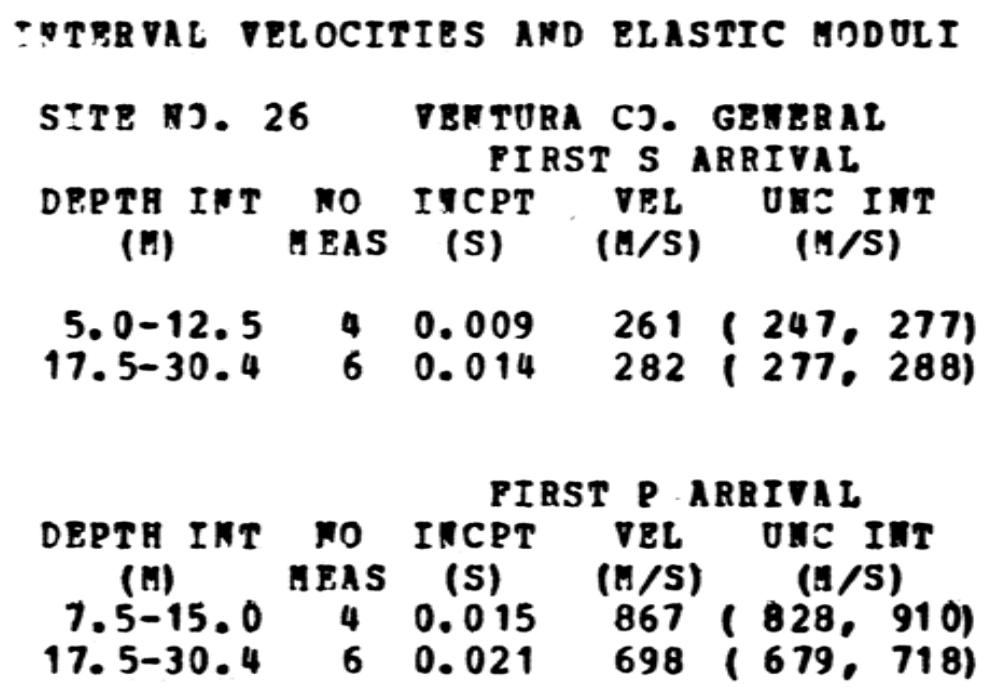

\begin{tabular}{|c|c|c|c|c|c|c|c|c|}
\hline $\begin{array}{c}S \\
\nabla B L \\
(H / S) \\
261 \\
282 \\
282\end{array}$ & $\begin{array}{c}\text { DEPTH IAT } \\
\text { (घ) } \\
5.0-12.5 \\
17.5-30.4 \\
17.5-30.4\end{array}$ & $\begin{array}{c}P \\
V E L \\
(H / S) \\
867 \\
698 \\
698\end{array}$ & $\begin{array}{c}\text { DEPTE IAT } \\
\text { (A) } \\
7.5-15.0 \\
17.5-30.4 \\
17.5-30.4\end{array}$ & $\begin{array}{c}\text { DBT } \\
\text { DEPTH } \\
\text { (H) } \\
6.1 \\
18.2 \\
30.0\end{array}$ & $\begin{array}{l}\text { SITI } \\
\text { (G/CC) } \\
1.76 \\
1.88 \\
1.87\end{array}$ & $\begin{array}{c}\text { SHEA R } \\
\text { HOD } \\
\text { (BAR S) } \\
1210 \\
1500 \\
1490\end{array}$ & $\begin{array}{c}\text { BOLE } \\
\text { HOD } \\
\text { (BAR S) } \\
11600 \\
7170 \\
7130\end{array}$ & $\begin{array}{l}\text { POI SsOIS } \\
\text { BATIO } \\
0.450 \\
0.402 \\
0.402\end{array}$ \\
\hline
\end{tabular}


This page intentionally left blank 

